NATHALIA CATHARINA ALVES OLIVEIRA

\title{
ALMA HIPERBÓLICA: \\ DRAMATURGIA DE UM CORPO MELANCÓLICO
}

Dissertação apresentada ao Programa de Pós-Graduação em Artes Cênicas, Escola de Comunicação e Artes, Departamento de Comunicação e Artes, da Universidade de São Paulo, como requisito parcial para a obtenção do título de Mestra em Artes Cênicas (Área de

Concentração: Teoria e Prática do Teatro; Linha de Investigação: Texto e Cena).

Orientação: Profa. Dra. Maria Helena Franco de Araújo Bastos.

São Paulo / SP 2017 
Autorizo a reprodução e divulgação total ou parcial deste trabalho, por qualquer meio convencional ou eletrônico, para fins de estudo e pesquisa, desde que citada a fonte.

Catalogação na Publicação Serviço de Biblioteca e Documentação

Escola de Comunicações e Artes da Universidade de São Paulo Dados fornecidos pelo(a) autor(a)

Alves Oliveira, Nathalia Catharina

Alma hiperbólica: Dramaturgia de um corpo melancólico Nathalia Catharina Alves Oliveira. -- São Paulo: N. C.

Alves Oliveira, 2017.

228 p. + inclui dvd.

Dissertação (Mestrado) - Programa de Pós-Graduação em Artes Cênicas - Escola de Comunicações e Artes / Universidade de São Paulo.

Orientadora: Maria Helena Franco de Araujo Bastos

Bibliografia

1. Walter Benjamin 2. Corporeidade 3. Melancolia 4. Dramaturgia I. Araujo Bastos, Maria Helena Franco de II. Título.

CDD 21.ed. - 700 


\section{FOLHA DE APROVAÇÃO}

Nome: OLIVEIRA, Nathalia Catharina Alves.

Título: Alma Hiperbólica: Dramaturgia de um corpo melancólico.

Dissertação apresentada ao Programa de Pós-Graduação em Artes Cênicas, Escola de Comunicação e Artes, Departamento de Comunicação e Artes, da Universidade de São Paulo, como requisito parcial para a obtenção do título de Mestra em Artes Cênicas (Área de Concentração: Teoria e Prática do Teatro; Linha de Investigação: Texto e Cena).

Aprovada em:

Banca Examinadora:

Prof.(a). Dr.(a).

Instituição:

Julgamento:

Assinatura:

Prof.(a). Dr.(a).

Instituição:

Julgamento:

Assinatura:

Prof.(a). Dr.(a).

Instituição:

Julgamento:

Assinatura: 

A alma é um anjo:

Ela não dorme nem acorda, não cansa nem descansa. Ela apenas sorri porque ama; e ama não alguém, mas o amor em si. Assim, sua morte nunca advém. ${ }^{1}$

Dedico esta pesquisa aos desconhecidos que nos trouxeram até aqui; aos não nascidos.

\footnotetext{
${ }^{1}$ De Poemas para Pauliceia (inédito), de minha autoria.
} 



\section{AGRADECIMENTOS}

Agradeço imensa e especialmente à Maria Helena Franco de Araujo Bastos pela acolhida, orientação, apoio, confiança, cuidado, carinho e dedicação ao longo dos últimos anos.

Aos meus avós e aos meus pais, pelo apoio incondicional e que me ensinaram a estudar, acreditar, amar, lutar, resistir, insistir e persistir.

A Cassiano Sydow Quilici e Maria Lucia Pupo pelo carinho, apreciação e cuidado na leitura e devolutiva crítica desta pesquisa.

À Bolsa Capes pelo apoio a esta pesquisa que me permitiu a dedicação com exclusividade ao estudo e aquisição da bibliografia.

Ao Programa de Pós-Graduação em Artes Cênicas, da Universidade de São Paulo (PPGAC/ECA-USP), especialmente à Tamara Elizabeth, pelos inumeráveis esclarecimentos e apoio ao longo desta pesquisa.

À Revista Sala Preta, pelo apoio e acolhida de artigo.

Às colegas do LADCOR, grupo de pesquisa orientado pela Profa. Dra. Maria Helena Franco de Araujo Bastos, no CAC-USP, por sua generosidade na leitura, crítica e compartilhamento.

À Maria Silvia Betti, Flávia Schilling, Antônio Araújo e Luiz Renato Martins com quem pude cursar as disciplinas de pós-graduação na Faculdade de Letras Modernas, na Faculdade de Educação e na Escola de Comunicação e Artes, da Universidade de São Paulo, e que contribuíram imensamente para minha reflexão nesta pesquisa.

À Gloria Hazan, pela inefável escuta, cuidado, formação, acompanhamento, apoio e carinho em vista do reconhecimento de nossa alma, potência, caminhos e escolhas.

À Valéria Cano Bravi e ao Curso de Dança da Universidade Anhembi Morumbi pela confiança e apoio para a realização de minha pesquisa prático-teórica e pela oportunidade de parceria. 

Aos Prof. Drs. Christian Dunker e Luciana Chaui-Berlinck, que aceitaram o convite de participar do projeto Anatomia da melancolia experiência I e que iluminaram este processo de pesquisa.

À Ana Cristina Teixeira, Carolina Camargo de Nadai, Edwiges Aragão, Leo Rodrigues, Maria Clara Ferrer, Maria Fernanda Vomero, Rosie Mehoudar, Sybil Douek e Valéria Menezes de Lima pelas conversas, escuta, apoio e interlocução carinhosa.

A Ivan Delmanto pela incomensurável interlocução crítica, discussões, referências, sugestões, revisão e leitura ao longo desta pesquisa.

À Luiza Rosa, pela cuidadosa revisão desta dissertação.

Aos aprendizes e colegas do Projeto Espetáculo da Fábrica de Cultura Capão Redondo e às alunas do Curso de Dança, da Universidade Anhembi Morumbi.

Aos meus parceiros de produção e criação, Anna Turra, Carolina Bianchi, Carolina Mendonça, Cau Fonseca, Dan Nakagawa, Elaine Calux, Fabricio Licursi, Guilherme Funari, Murilo Chevalier, Patrícia Cividanes, Tatiana Tatit e à equipe do SESC Pompéia por acolher Anatomia da Melancolia - experiência I.

Aos meus professores do ensino médio e da graduação em Comunicação das Artes do Corpo (PUC-SP).

À Ana Panzani Alves, Ana Paula Dias, Bruno Nomaksteinsky, Daniel Athayde, Diogo Granato, Gabriela Germano, Gabriela Tarcha, Lucas Barreto e Marina Correia, pela longa, constante, profunda e eterna compreensão e amizade. 

"Será esta paisagem/imagem da rua de mão única

que pretendeis seguir?

Tenho cá minhas dúvidas. Mas acabei aonde quereis ir!

Tantas ruas têm retorno que não se vê.

$E$ a quem entra na contra-mão

Não é certo que nada lhe aconteça.

Em caso de colisão não há discussão:

o raio cai mesmo.

E de repente não só parece

Como te encontras transformado de todo.

Nos velhos tempos todos os caminhos, de alguma forma

Levavam a Deus, e seu nome, de algum modo.

Não somos piedosos. Ficamos no profano

e onde estava Deus antes, hoje está a melancolia."

(Walter Benjamin e Gershom Scholem.

Correspondência.). 



\section{RESUMO}

Alma Hiperbólica: dramaturgia de um corpo melancólico é uma dissertação que une teoria e prática para refletir sobre o que chamamos de corporeidade e dramaturgia melancólicas. Investigamos a experiência social subjetiva hipermoderna, por meio de um estudo centrado na ideia de melancolia, aqui entendida como sintoma de um sistema econômico, social e político gerador de miséria subjetiva e, de outro lado, como potência de resistência e de criação de uma nova anatomia de nossa experiência física e social. A potência deste corpo melancólico ancora-se na sua capacidade de revelar nossa condição hipermoderna como um estado de exceção, interessando-nos pesquisar a linguagem artística que pode ser elaborada neste processo de tradução do "vazio melancólico" em corporeidade. Nossa pesquisa partiu de um processo de criação artística, o solo Anatomia da Melancolia - experiência I, em que o material teórico foi experimentado como corporeidade e dramaturgia. Nessa pesquisa, propomos uma perspectiva dialética, no limiar de uma reflexão filosófica, sociológica e histórica, tendo como referências bibliográficas principais os autores Walter Benjamin, Georges DidiHuberman, Giorgio Agamben, Julia Kristeva e Theodor Adorno.

Palavras-chave: Walter Benjamin; Melancolia; Corporeidade; Dramaturgia dialética. 



\begin{abstract}
Hyperbaric Soul: dramaturgy of a melancholic body is a dissertation that unites theory and practice to reflect upon we call melancholic corporeity and dramaturgy. We investigate the hypermodern subjective social experience through a study centered on the idea of melancholy, which here understood as a symptom of an economic, social and political system generating subjective misery and, on the other hand, as a power of resistance and creation of a new anatomy of our physical and social experience. The power of this melancholy body is anchored in its ability to reveal our hypermodern condition as a state of exception, interested in researching the artistic language that can be elaborated in this process of translating the "melancholic void" into corporeity. Our research started from a process of artistic creation, the solo Anatomy of Melancholy experiment $I$, in which the theoretical material was experienced as corporeity and dramaturgy. We use a dialectical perspective, at the threshold of a philosophical, sociological and historical reflection, with bibliographical references such as Walter Benjamin, Georges DidiHuberman, Giorgio Agamben, Julia Kristeva and Theodor Adorno.
\end{abstract}

Keywords: Walter Benjamin; Melancholy; Corporeity; Dialectical dramaturgy. 



\section{LISTA DE IMAGENS}

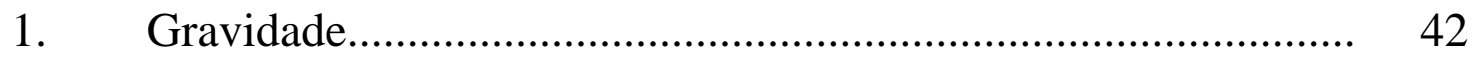

2. Espasmos hipertônicos.............................................................. 95

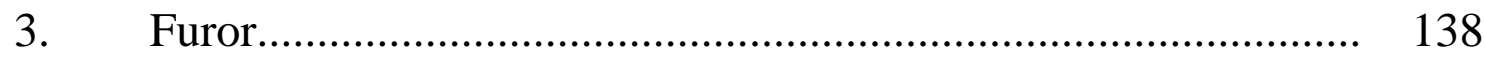

4. Montagem - Atlas Mnemosyne de Aby Warburg........................ 142

5. Melancholia I.................................................................... 151

6. Atrofia muscular e membros fantasmas...................................... 180

7. Leitura a partir de DÜRER ...................................................... 181

8. Apreender o invisível............................................................ 203 



\section{SUMÁRIO}

PAISAGEM DA INVISIBILIDADE............................................ 13

Hipérbole negativa............................................................... 35

CAPÍTULO 1: CONTRADIÇÃO MANIFESTA............................... 43

Melancolia............................................................................... 43

Corpo do limiar...................................................................... 46

Modernidade e melancolia.......................................................... 52

A poética de Baudelaire: negação e choque..................................... 58

Melancolia e o estranho............................................................ 72

Corporeidade do choque.......................................................... 84

CAPÍTULO 2: RASTROS E IMAGEM DIALÉTICA..................... 97

Rastros da violência........................................................ 120

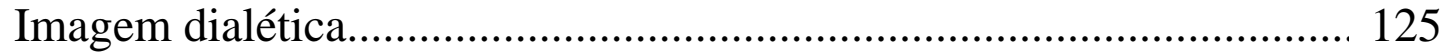

CAPÍTULO 3: MNEMOSYNE SOBREVIVENTE.......................... 139

Utopia melancólica: revolução permanente..................................... 166

Desordem e tragédia.............................................................. 173

CONCLUSÃO: CORPOREIDADE DA AUSÊNCIA...................... 183

Correspondências...................................................................... 196

Ultimíssimo dia..................................................................... 202

REFERÊNCIAS BIBLIOGRÁFICAS........................ 205

Dramaturgia textual - Anatomia da Melancolia-experiência I...... 217 


\section{PAISAGEM DA INVISIBILIDADE}

De Aristóteles na sua Problemata $(30$, I)

à Schiller (Sobre a poesia ingênua e sentimental, 1795), Walter Benjamin (Origem do Drama Barroco Alemão, 1916-1925) e até os nossos dias, o sol negro da melancolia não cessa de se mostrar como esse rasgo, no próprio centro de nossa identidade, que acompanha ou mesmo engaja o esforço de pensar e de falar.

Julia Kristeva.

Eu era invisível. Minha revolução era tornar este vazio um corpo visível. Este sentimento de vazio criou um buraco em minha perna em 1992, na perna esquerda ${ }^{1}$. Em agosto de 2013, tive uma dor muito forte nesta mesma perna e todo o meu lado esquerdo ficou paralisado. Aos poucos, consegui me levantar e conviver com a dor. Durante a paralisia, era como se meu corpo todo estivesse sintetizado nesta perna e ela me dizia: - Agora é para esta perna que você irá olhar, ela é seu braço, ela é seus olhos, ela é seu coração, ela é sua cabeça; ela é seu corpo. Enfim. Eu era uma ruína de perna. Naquele momento, esta era a imagem da minha melancolia.

Logo após a crise de dor, eu embarquei para Frankfurt, em uma residência artística para solistas chamada Narration/No narration, para a

\footnotetext{
1 Minha tíbia era "incompleta". No período de aproximadamente $3 \mathrm{~cm}$, embora eu tivesse a camada mais externa da tíbia esquerda, ela era vazia por dentro. Nesse buraco havia apenas uma cartilagem benigna, quase transparente, que morava lá dentro. Dançando ao longo dos últimos dezesseis anos, diversas vez caí, torci, distendi e ao fazer radiografias, pudemos ver que os ossos do restante de meu corpo são cheios de buracos, porém bem menores que este da tíbia esquerda.
} 
qual fui selecionada. Ali, começava meu mergulho em um corpo melancólico. Comecei a perceber esta perna em toda a paisagem: eu via a cidade como uma ruína. Tudo está parado, sem movimento, esta cidade é uma perna vazia; os prédios e as pessoas eram, assim como eu, uma perna esburacada, os interiores dos apartamentos e dos corpos eram uma imensa tíbia vazia. Percebi que o que estava pesquisando não parecia um vazio só meu, individual, mas que meu corpo era parte e testemunha de uma melancolia mais ampla, impregnada nas paredes das velhas cidades, ruínas de uma civilização que já desaparecera, mas que se sustentava por finos tendões artificiais, como próteses pós-holocausto. Então me perguntei se a melancolia não seria uma espécie de discurso, de linguagem, de corpo? Esta era uma forma de narração/não-narração? Uma narrativa a partir da paralisia do corpo, do colapso da história civilizatória ocidental?

As ruínas da velha Europa que eu via eram as ruínas dos meus olhos, esses buracos vazios como janelas de um apartamento inabitado. Buracos de uma história que não era só minha - minha melancolia também era a melancolia do mundo. Meu fracasso não seria um fracasso individual, mas também o de uma história partilhada. Meu "Eu", meu corpo, enfim, não era só um indivíduo, mas um todo disperso como lascas de uma história perdida no esquecimento dos dias.

Ao voltar ao Brasil, dei-me conta que o que eu via já havia sido constatado por Walter Benjamin², autor que notou a construção destas

\footnotetext{
${ }^{2}$ Walter Benjamin (Berlim; Alemanha, 15 de julho de 1892 - Portbou; Espanha, 27 de setembro de 1940) foi um dos mais importantes pensadores judeus alemães do século XX. Inspirado tanto por autores marxistas como Bertolt Brecht, como pelo filósofo judaico, estudioso da Cabala, Gershom Scholem, Benjamin entrelaça ideias aparentemente contraditórias do materialismo dialético, do idealismo alemão e do misticismo judaico. Filósofo, ensaísta, sociólogo, crítico literário e tradutor, após a rejeição de sua tese de livre-docência, intitulada Origem do drama trágico alemão, pela
} 
ruínas e que foi afetado por elas sendo, ele mesmo, uma de suas testemunhas. Não à toa, esse pensador tornou-se meu principal interlocutor nesta jornada melancólica, tanto em relação ao conteúdo da pesquisa quanto à forma, ensaística, que escolhi para escrever o texto desta dissertação. Procurei escrever e dançar a partir de conceitos filosóficos, econômicos, sociológicos, ensaiando traçar outras palavras, constelações e alegorias, seguindo as pistas de Walter Benjamin, que também buscara outra forma, analítica e ensaística, para um pensamento filosófico e estético e que procurara realizar algo, em princípio, inconcebível: unir o materialismo histórico, de proveniência marxista, ao misticismo judaico.

Sobre a leitura e interlocução traçada com este autor, nesta dissertação, é importante ressaltar que:

Benjamin não apenas "pensava poeticamente" mas também escrevia como pensava - no sentido de determinadas palavras, ao invés de serem portadoras de um conceito claramente definido, ganharem um sentido próprio pela mera intensificação do seu uso dentro do próprio texto (...). Sem poder contar com a facilidade de uma definição prévia, o leitor é obrigado a conquistar o sentido da palavra no decorrer da leitura, sendo que essa conquista pelo menos é facilitada pelo uso sempre igual do mesmo termo. (OTTE, 2012: 71)

De certo modo - e não por acaso - a forma da escrita adotada por Walter Benjamin, e que nos serviu de inspiração para a própria forma da

\footnotetext{
Universidade de Frankfurt, que a considerou pouco convencional, abandonou a carreira acadêmica. Escreveu peças para rádio, além de artigos para diversos jornais e revistas literárias. Colaborou com a Zeitschrift für Sozialforschung, revista do Instituto de Pesquisa Social (que mais tarde ficou conhecido como "Escola de Frankfurt"). Filho de judeus, precisou deixar a Alemanha, em 1933, rumo a Paris, onde ficou até a invasão nazista. Em 1940, fugiu ilegalmente para a Espanha e, na cidade de Portbou, Catalunha, suicidou-se para não ser capturado pela Gestapo.
} 
escrita desta dissertação, revela a impossibilidade de se construir e narrar uma história linear da modernidade, devido à própria complexidade de seu conteúdo histórico, a saber, uma história plena de contradições, buracos, lacunas. Seria a partir dessas contradições que o corpo melancólico, aqui investigado, encontra as motivações tanto para seu abatimento, quanto para sua linguagem, corpo que podemos entender como uma forma de sobrevivência e resistência em relação às contradições de sua época. Uma corporeidade melancólica nasceria do choque entre um corpo e seu contexto de origem, como uma possibilidade de "sobrevivência" do próprio corpo:

Benjamin reproduz, portanto, pela própria escrita, um mecanismo que, por mais precário que seja, permite que momentos distantes se relacionem pelo menos temporariamente, sinalizando uma coesão que não é mais aquela de um fundamento universal e imutável, nem aquela da plausibilidade lógica e empírica das ciências, mas que se baseia no relampejo "messiânico" dos índices. Além de detectar esses índices da história moderna, Benjamin se serve deles para "salvar" a escrita moderna de sua dissolução definitiva. (OTTE, 2012: 83)

A forma ensaística, que procuro experimentar nesta dissertação, parte da "tentativa de salvamento da escrita", empreendida por Benjamin, que procura fazer do choque entre diferentes conceitos, advindos de áreas distintas do conhecimento, constelações tão contraditórias quanto a corporeidade melancólica, nosso tema de estudo ${ }^{3}$. Do mesmo modo, a

\footnotetext{
3 “"...] Benjamin foi um filósofo. O foi em todas as fases de sua atividade e em cada uma das formas que esta adotou. Visto de fora, escrevia em geral sobre assuntos da literatura e da arte, com frequência também sobre fenômenos situados na fronteira da literatura e da política, e apenas raras vezes sobre objetos reconhecidos e julgados convencionalmente como temas da filosofia pura. Mas o que em tudo isso o movia eram as experiências do filósofo. Com a palavra 'metafísica' se alude à experiência filosófica do mundo e sua realidade, e certamente era este o uso que lhe dava Walter Benjamin.". (SCHOLEM, 2004: 19) (Tradução nossa)
} 
escrita corporal, dramatúrgica ${ }^{4}$ de Anatomia da melancolia - experiência

$I$, buscou criar, tal como Benjamin, uma linguagem que se forma a partir de passagens, dos limiares de planos que se chocam entre si, processo próprio à subjetividade melancólica que não se caracteriza pela linearidade narrativa, mas pela justaposição não fusional de seus estados, fluxos energéticos e imagens rememoradas:

[a melancolia, em Benjamin] é o efeito e a causa de uma determinada sobreposição de imagens que perpassa, assumindo sempre novos traços e criando sempre novas correlações ${ }^{5}$, sua obra. (LAGES, 2007: 104)

Consideramos a atualidade dos conceitos benjaminianos, para a compreensão do momento histórico contemporâneo, a partir do que nos diz João Barrento, ensaísta português e tradutor de Walter Benjamin:

A História como pântano (...) é uma leitura marcada [...], em Benjamin, por um pensamento negativo e da crise $[\ldots]$ que a história do último século até há bem pouco tempo alimentou e legitimou de forma gritante - e não apenas com as duas Grandes Guerras, o

\footnotetext{
${ }^{4}$ Consideramos aqui a noção de dramaturgia relacionada não somente com a escritura de textos teatrais, mas sim com a articulação dos diversos elementos que compõem a cena, a partir de uma relação não hierárquica de funcionamento. A palavra, oral ou escrita, deixa de ser, por meio dessa noção ampliada de dramaturgia, a matriz semântica privilegiada do espetáculo, mas estabelece uma relação de dependência com os outros elementos, tais como o figurino, a cenografia e a música, contribuindo para a construção de uma espécie de tecido, composto por várias camadas, que se articulam mas não se reforçam ou ilustram, simplesmente. A unidade estética nesses casos é resultante de um profundo jogo de tensões, em que esses diversos elementos cênicos não convergem para um mesmo ponto, mas são entrelaçados de diversas maneiras, são 'tecidos'. Consideramos, assim, a dramaturgia como uma espécie de "textura".

5 "Seus trabalhos [de Walter Benjamin] exigem do leitor um extraordinário nível de concentração. Seu pensamento era de grande densidade e implacável na concisão frequentemente extrema da formulação. Assim, seus trabalhos devem ser meditados, se me permitem dizer desta forma. Ao mesmo tempo, foram escritos em geral em uma prosa perfeita, da qual irradia um estranho poder". (SCHOLEM, 2004: 21) (Tradução nossa)
} 
nazismo e o estalinismo, também com as guerras do Vietnam, dos Bálcãs, do Iraque, com os genocídios de Camboja ou de Ruanda. [...] O nosso tempo de viragem do milênio, por mais distante que pareça estar daquele em que Benjamin viveu e escreveu, o do "ovo da serpente" em gestação, é filho dele e um prolongamento seu, apesar de suas marcas de superfície serem de sinais contrários. (BARRENTO, 2005: 20-30)

Assim como fez Benjamin, inspiro-me em Montaigne, que contrapunha a forma do ensaio à escrita dos tratados de rigor acadêmico: "se me deparo com um tema de que nada sei, por isso mesmo o ensaio, sondando esse abismo desde longe; depois, se o acho demasiado profundo para minha estatura, permaneço à margem" (MONTAIGNE, 2011: 605) (Tradução nossa). Para o filósofo francês, esse reconhecimento de não poder ir mais além é uma característica da modéstia de pretensões da forma ensaística, que não se pretende universal: "Outras vezes, o levo em passeio por um tema elevado e muito transitado, em que nada seu pode encontrar, por estar em caminho tão trilhado que somente pode caminhar depois das pegadas de outro" (Idem). Nesse caso, o pensamento ensaístico "desempenha sua tarefa elegendo a rota que lhe parece melhor". Montaigne faz a seguinte metáfora para descrever a forma ensaística: "De cem membros e rostos que cada coisa tem, ora tomo um para apenas tocá-lo com a ponta da língua, ora para roçá-lo com os dedos, e às vezes para beliscá-lo até o osso. Faço uma incisão, não a mais ampla, senão a mais profunda possível” (Idem). E, para o ensaísta, com relação a esse mesmo pensamento, "agrada surpreendê-lo sob uma luz insólita” (Idem).

Na escrita desta dissertação, parto de certa "luz insólita", segundo a qual não suponho a separação entre o corpo, por assim dizer, 
"filosófico" e o "corpo da bailarina". Dança e filosofia estão aqui em relação de liminaridade. O que leio, danço. O que danço, leio. Quando reflito a partir de um termo, conceito ou texto filosófico, traduzo-o em corporeidade $^{6}$. Foi o que ocorreu nesta pesquisa teórico-prática, em que a teoria tornou-se dança e a dança retornou à teoria, traçando outras relações entre seus conceitos filosóficos de origem. Colocava-me em experiência carnal com os conceitos que estudava: como se os conceitos me atravessassem, a todo momento, em um tempo presente, contaminado de passado e futuro, e que disparavam em meu corpo - tal como palavras que se tornam carne - fluxos energéticos/humorais que, imediatamente, manifestavam-se como fluxos cinéticos.

\footnotetext{
${ }^{6}$ Corporeidade, na neurologia, refere-se às manifestações do corpo em relação ao seu contexto, a esta capacidade do corpo manifestar sua interação com o mundo. A partir das ideias do filósofo Maurice Merleau-Ponty, nossa inspiração para a definição do conceito trata do "corpo vivido" ou do "corpo animado". O filósofo não estabelece uma diferenciação entre corpo e sujeito ou, ainda, corpo e objeto, mas, ao contrário, trata a noção de corpo como "vidente-visível", corpo como "carnalidade". É desse sentido de carnalidade que se desprende a noção de corporeidade para o autor: "Engajo-me com meu corpo entre as coisas, elas coexistem comigo enquanto sujeito encarnado, e essa vida nas coisas não tem nada de comum com a construção dos objetos científicos" (MERLEAU-PONTY, 2006: 252). Para Merleau-Ponty, "a carne não é matéria, não é espírito, não é substância. Seria preciso, para designá-la, o velho termo elemento, no sentido em que era empregado para falar-se da água, do ar, da terra e do fogo, isto é, no sentido de uma coisa geral, meio caminho entre o indivíduo espaço-temporal e a ideia, espécie de princípio encarnado que importa um estilo de ser em todos os lugares onde se encontra uma parcela sua" (MERLEAU-PONTY, 1992: 135). Merlau-Ponty nos recorda que antes que as coisas sejam apreendidas pela reflexão como entidade objetiva, existe uma comunicação física entre o corpo e o que o circunda, que se nutre de nosso "co-pertencimento a um ambiente ou espaço existencial". De certo modo, impregnamos as coisas, as paisagens, a temporalidade e a espacialidade com nossa carnalidade. "A identidade da coisa através da experiência perceptiva é apenas um outro aspecto da identidade do corpo próprio (corporeidade) no decorrer dos movimentos de exploração" (grifo nosso) (MERLEAU- PONTY, 2006: 252). Ainda quanto à corporeidade, há que se levar em conta a proximidade do termo com aquilo que Pierre Bourdieu pensa sobre o "habitus". Ao elaborar aquilo que entendemos por "habitus" em sua teoria, Bourdieu aproxima suas reflexões à noção de "incorporação". Para o autor, a ordem social se inscreve no corpo por meio de confrontos permanentes e nesse sentido, pensar em "incorporação" é entender que interiorizamos uma série de disposições históricas e corporais ao longo do tempo (BOURDIEU, 2003: 135).
} 
Neste processo dramatúrgico, no qual as palavras estão encarnadas, como espécies de conceitos humorais-motores, identifico linhas de força - conceituais e motores - capazes de gerar um entrelaçamento, danificado e arruinado, entre um materialismo histórico e uma concepção messiânica, criando um corpo "em constelação", no limiar da teoria e da experiência da carne, movido por uma espécie de utopia de futuro esquecida nos crimes do passado.

Em muitos momentos, a dissertação nascia da sala de ensaio, enquanto meu corpo se movia e eu passava a escrever sobre um papel e, do mesmo modo, em outros momentos, a dramaturgia nascia da minha mesa de trabalho, enquanto estava em experiência teórica de escrita e que, então, começava a me mover. Teoria e corpo se constelavam liminarmente, a um ponto em que, hoje, eu não teria mais condições de estabelecer onde se localiza uma e outro. Meu corpo estava em experiência de ensaio desta dissertação e da dança. O que me movia a escrever eram os fluxos energéticos-cinéticos que, por sua vez, eram desencadeados pelas relações conceituais que meu corpo traçava em si mesmo e no espaço (e, então, escrevia para não esquecer), em um processo infinito. A escrita parecia nascer não para garantir e concluir

\footnotetext{
${ }^{7}$ Sobre a ideia de constelação: "Quando dois fenômenos, cronologicamente distantes e aparentemente heterogêneos, colocados em cotejo entre si, iluminam-se reciprocamente, revelando certa afinidade interna entre seus teores factuais, lampeja, diante do crítico, uma configuração - ou, para falar em termos mais propriamente benjaminianos, uma "constelação" - verdadeira da história, uma imagem da história que lhes é interna. Em oposição à moderna filosofia da representação, que aplica sobre os fenômenos, para conhecê-los, uma espécie de "grade" previamente forjada pelo sujeito, o trabalho interpretativo do crítico é então concebido como o esforço de imergir "nos pormenores do conteúdo material" (...) de cada obra para, a partir daí, extrair e trabalhar seus elementos extremos, que sobressaem e escapam a qualquer padronização, colocando-os em contraste com outros e reorganizando-os em uma nova constelação: assim, os fenômenos revelar-se-iam em sua historicidade interna, em suas pré e pós-história, as quais não equivalem a fenômenos que lhes antecedem e sucedem por uma proximidade cronológica, mas que podem estar separados por séculos." (BOTELHO, mai. 2012: 108).
} 
algumas certezas, mas para revelar aquilo que me desconcerta, aquilo que não sei.

Para além dos limites dessa materialidade, eu me colava em uma espécie de mesa de dissecação da história, cujo anatomista movia suas mãos e bisturis: minha hipótese era que iria encontrar um outro conceito de história e de corpo, como se desta operação-investigação, uma determinada "temporalidade messiânica" ${ }^{8}$ pudesse chegar a qualquer momento ou, então, que ela já estivesse ali, soterrada sob uma carne já danificada e que requer um trabalho para ser revelada. Tal parece ser a tarefa deste corpo melancólico. O anatomista, envolvido em uma "estranha esgrima" entre a vida e sua finitude, dissecando este corpo e a história, analisando o passado e encontrando a causa mortis de um dos cadáveres da história, parece tornar-se uma espécie de "testemunha do futuro": ao desvelar o mistério da causa mortis, aquilo que foi perdido em vida, procura criar uma outra anatomia e conceito para a vida futura.

Este corpo que escreve é o ensaístico, o estético, o movente, o político: é tanto a metonímia da nossa miséria social, quanto a hipérbole da esperança e de uma redenção estético-filosófica. Ressalto que, aqui, a ideia de redenção diz respeito àquilo que poderia ter acontecido, mas que ainda não aconteceu, a uma espécie de devir. Tentemos esclarecer. Em sua tese II, de Sobre o conceito de história, Benjamin diz que "a imagem

\footnotetext{
${ }^{8}$ Menciono aqui a ideia de temporalidade messiânica, que desenvolveremos adiante, no sentido da espera, ativa e utópica, por transformações e pela superação da realidade traumática. "O Messias não virá até que já não seja necessário, e mais, chegará depois de sua própria vinda, não virá no último dia, senão no dia posterior ao último, no ultimíssimo dia." (KAFKA, 2003: 621-623) (Tradução nossa)

${ }^{9}$ Walter Benjamin usa esse termo, em carta de 1927 à Scholem, para designar aqueles que testemunham como certa a vinda do Messias, "o poeta que o sente, o escultor que o vê, o músico que o ouve e o filósofo que o conhece", embora seus testemunhos não concordassem entre si (ver BOURETZ, 2011: 21).
} 
da felicidade é inseparável da redenção":

"Entre os atributos mais notáveis da alma humana", diz Lotze, "conta-se (...) no meio de tantas formas particulares de egoísmo, a ausência generalizada de inveja de cada presente em relação ao seu futuro". Essa reflexão leva a que a imagem da felicidade a que aspiramos esteja totalmente repassada do tempo que nos coube para o decurso da nossa própria existência. Uma felicidade que fosse capaz de despertar em nós inveja só existe no ar que respiramos, com pessoas com quem pudéssemos ter falado [...]. Por outras palavras: na ideia que fazemos da felicidade vibra também inevitavelmente a da redenção. $\mathrm{O}$ mesmo se passa com a ideia de passado de que a história se apropriou. $\mathrm{O}$ passado traz consigo um índice secreto que nos remete para a redenção. Não passa por nós um sopro daquele ar que envolveu aqueles que vieram antes de nós? Não é a voz a que damos ouvido o eco de outras já silenciadas? [...] A ser assim, então existe um acordo secreto entre as gerações passadas e a nossa. Então fomos esperados sobre esta Terra. Então, foi nos dada, como a todas as gerações que nos antecederam, uma tênue força messiânica a que o passado tem direito. Não se pode rejeitar de ânimo leve esse direito. (BENJAMIN, 2012b: 9-10).

Para compreendermos a tese acima, vale cruzarmos sua leitura com uma citação presente na obra Passagens, de Benjamin, dedicada à Hermann Lotze $^{10}$ (autor mencionado na tese acima). Na passagem [N 13a, 1], Lotze estabelece a relação entre redenção e o tempo histórico, posição na qual Benjamin se reconhece inteiramente:

Esta felicidade está fundada precisamente em nossa desesperança e abandono. A nossa vida, para dizer as coisas de outra forma, é um músculo que tem força suficiente para contrair a totalidade do tempo

\footnotetext{
${ }^{10}$ Hermann Lotze (1817-1881), foi um filósofo judeu alemão, participante de uma corrente idealista próxima do monadismo de Leibniz.
} 
histórico. Ou ainda, a concepção autêntica do tempo histórico repousa inteiramente sobre a imagem da redenção. (BENJAMIN, 1989: 497-498) (Tradução e grifos nossos)

Assim, a ideia de redenção se relaciona diretamente à capacidade do corpo de constelar em si mesmo, em seus próprios músculos, a totalidade do tempo histórico. Assim, ao falarmos de "redenção" não entendemos a chegada a uma espécie de síntese, superação ou salvação, de um "fim" a ser alcançado segundo uma doutrina idealista da história, mas sim, a uma espécie de "nostalgia de um futuro" (aquilo que poderia ter ocorrido) que só se pode construir em nossa vida presente, a partir de uma constelação de tempos e corpos históricos.

Se partimos da concepção de um corpo do limiar, podemos dizer que uma articulação filosófica das ideias pode ser vista como uma constelação artística e estética das ideias: não se trata de um corpo ora artístico, ora social e cultural, de um corpo que pensa filosoficamente e, em seguida, esteticamente; mas de um corpo que procura operar em uma espécie de síncope tempo-espacial; corpo que pode ser visto como uma constelação de diversos "corpos", dado que pensar é dançar, dançar é pensar, dançar é escrever no espaço histórico. Procurei, dessa forma, escrever considerando os limiares dos fluxos físicos-energéticos e históricos.

Escrever ensaísticamente, nesta dissertação, significou compor experimentando virar e revirar meu objeto de estudo - o solo de dança Anatomia da Melancolia - experiência I -questionando-o, atacando o conceito de melancolia sob diversos lados, colocando em palavras o que 
cada gesto esconde e permite vislumbrar. $\mathrm{O}$ ensaio ${ }^{11}$ pode ser tomado como uma forma artística, dado que a forma do texto se relaciona à corporeidade que encontrei ao dançar um corpo melancólico. Daí minha escrita alegórica, a partir de um procedimento também experimentado no corpo que dança, forma contaminada pela própria estrutura da escrita benjaminiana - cujas conexões das ideias não se fazem de modo sequenciado - mas palimpséstico, tecida a partir de sobreposições, perfurações e ruínas. Os conceitos desta dissertação, sempre relacionados à matriz da corporeidade melancólica, não se sucedem no tempo de maneira linear, o pensamento avança e retrocede, repete e retoma para depois seguir adiante, recontextualizando e reconfigurando os conceitos, na medida em que esses se organizam, a cada momento, em novas constelações.

Percebi, em suma, na medida em que ensaiava esta dissertação, que o buraco da minha perna era apenas a parte de um todo, que minha tíbia vazia era a narradora de uma história mais ampla que a minha, que a de um indivíduo. Essa perna era um dos traços de um mundo esburacado. Tal paisagem arruinada é definida, pelo economista Immanuel Wallerstein, como um totalitário sistema-mundo: "No final do século XV e começo do XVI, nasceu o que poderíamos chamar de uma economiamundo europeia". Sobre essa nova forma de sociabilidade de caráter mundializado, "trata-se de uma única entidade econômica, que em seu

\footnotetext{
${ }^{11}$ Segundo Larrossa: "O ensaio, então, não é mais a expressão de um sujeito, mas o lugar no qual a subjetividade ensaia a si mesma, experimenta a si mesma, em relação à sua própria exterioridade, àquilo que lhe é estranho." (2004: 37). Para Adorno, o ensaio possui precisamente essa característica de superar as divisões territoriais entre subjetividade e objetividade, arte e ciência: "O ensaio, porém, não admite que seu âmbito de competência lhe seja prescrito. Em vez de alcançar algo cientificamente ou criar artisticamente alguma coisa, seus esforços ainda espelham a disponibilidade de quem, como uma criança, não tem vergonha de se entusiasmar com o que os outros já fizeram. [...] Felicidade e jogo lhe são essenciais." (ADORNO, 2007: 16).
} 
espaço convive com diferentes formas de entidades políticas (império, cidades-estados, nações-estado), sendo maior que qualquer uma delas, e por isso constitui-se num "sistema mundial". Na perspectiva que adotamos nesta dissertação, "o sentido da colonização não seria a aceleração da acumulação primitiva e da acumulação propriamente capitalista, mas a formação de um sistema social histórico específico, o moderno sistema-mundo, sinônimo de economia-mundo capitalista". O Brasil, país assolado por esse processo de colonização, seria vinculado a essa economia mundial, à força, por um violento "processo histórico de formação do capitalismo moderno, à transição do capitalismo comercial para o industrial (capitalismo pleno) (WALLERSTEIN, 2006: 73).

Esse sistema-mundial integra a produção de ruínas europeia às ruínas que meu corpo viveu, desde sempre, no Brasil. Em 1993, foi com um pedaço de meu próprio corpo que, artificialmente, preenchi minha tíbia, enxertando parte de minha crista ilíaca esquerda na perna, criando assim o prólogo de uma dramaturgia interna que poderia ser vista como um microcosmo particular, mas que, alegoricamente, pode ser vista como sintoma de um processo histórico, cultural e social, partilhado. O "meu" corpo não é meu corpo apenas, não é propriedade, não é privado. $\mathrm{O}$ meu corpo é também um corpo social em sua melancólica narrativa; ele é também a testemunha e a história de uma melancolia generalizada. A perna cheia de buracos é também uma das mãos que escreve nossa história social, ou ao menos, uma de suas falanges. Nossa “(...) época é também o que encontramos no fundo de nós mesmos, quando aceitamos descer até lá (...). É no fundo de cada situação e no fundo de cada um que é preciso procurar a época. É aí que nos encontramos (...).” (COMITÊ INVISÍVEL, 2016: 20). 
A melancolia não pode ser vista apenas como mero sentimento de tristeza, como prega o senso comum. Ela é o resultado de uma contradição, reveladora de um desejo utópico de reconstituição de um todo perdido e vazio. Ela é a ocupação desse vazio, sua crispação. Sobre o que se debruça, o melancólico? Sobre o infinito de alhures, sobre um tão longe que crispa tão perto. Esse alhures longínquo é próximo, é nossa modernidade ou ainda, nossa hipermodernidade (LIPOVETSKY, 2004), que se colapsa envolta nos braços de sua própria crise, de sua própria ruína, gerada pelo progresso do capitalismo como sistema-mundo de produção. Corpos autômatos, privados de relações autênticas por meio das quais se faria possível reconhecer a tragédia de nossa "perna" comum, de nossa história e ruínas comuns.

Nosso processo histórico capitalista nos revela a tragédia como norma: tornamo-nos cegos para as faltas, cegos para a miséria ao nosso redor, para a miséria de nosso próprio corpo e de sua experiência no mundo. A miséria da alma, a violência e injustiça geradas por esse sistema, de tão comuns, ordinárias e cotidianas, se transformam em "normalidade": tornam-se invisíveis. Temos a aparente sensação que as aceitamos "normalmente" e, na verdade, estamos passando por um processo hiperviolento de amputação, supressão, retaliação e repressão do próprio corpo: ao ignorar a tragédia, uma segunda violência é criada, em nossa subjetividade. Este rasgo hiperviolento na alma é uma das faces da constelação que chamo de melancolia.

Nossa formação foi determinada a partir de tecnologias de cegueira e apagamento subjetivo, a começar pela divisão econômica do trabalho que rege as relações sociais e subjetivas do corpo contemporâneo, que evitam ao máximo abrir espaço para uma experiência coletiva e social autêntica, dado o perigo que um 
investimento como esse poderia acarretar para a "ordem e progresso" da civilização dos últimos três séculos. A potência do corpo melancólico defendida nesta pesquisa se ancora na capacidade que esse parece ter de revelar nossa tragédia hipermoderna como um estado de exceção (e não de normalidade). Nossa contemporânea hipermodernidade 12 (LIPOVETSKY, 2004), seria o sintoma final deste colapso moderno, o estado hiperbólico de coma da modernidade.

A definição de "tragédia moderna" foi formulada, pelo filósofo e crítico literário Raymond Williams, para apreender as mudanças históricas geradas pelo capitalismo durante sua etapa de modernização: "Williams defende a noção de que há experiências em nosso cotidiano que podem e devem ser consideradas como tragédia, a despeito da oposta visão hegemônica acadêmica". Para o autor inglês, assim como "cada época trouxe uma nova forma de entender o conceito de tragédia, também nosso mundo contemporâneo vivenciou novos problemas que exigem novas forma de análise" (LEME, 2007: 31). Fazendo uma distinção entre o momento histórico que gerou a noção tradicional de tragédia e o contexto histórico, trágico, do presente, "enquanto os gregos conheciam as razões de seus sofrimentos, a nossa sociedade, pelo seu caráter individualizado, não consegue relacionar suas vidas ao mundo ao redor, nem tampouco, suas vidas às de outrem" (LEME, 2007: 35). De

\footnotetext{
12 "Hipercapitalismo, hiperclasse, hiperpotência, hiperterrorismo, hiperindividualismo, hipermercado, hipertexto - o que mais não é hiper? O que mais não expõe uma modernidade elevada à potência superlativa? (...) modernização desenfreada, feita de mercantilização proliferativa, de desregulamentação econômica, de ímpeto técnicocientífico (...). Tudo foi muito rápido: a coruja de Minerva anunciava o nascimento do pós-moderno no momento mesmo em que se esboçava a hipermodernização do mundo. Longe de decretar-se o óbito da modernidade, assiste-se a seu remate, concretizando-se no liberalismo globalizado, na mercantilização quase generalizada dos modos de vida, na exploração da razão instrumental até a 'morte' desta, numa individualização galopante." (LIPOVETSKY, 2004: 48).
} 
outro lado, segundo Williams, "o desenvolvimento social foi considerado como necessariamente contraditório em caráter, e a tragédia ocorre naqueles pontos em que forças conflitantes precisam, pela sua natureza, agir e levar o conflito a uma transformação." (WILLIAMS, 2002: 57).

O choque ou luta entre forças conflitantes é o princípio motriz desta dissertação e do solo de dança Anatomia da Melancolia experiência I. Também o conceito de messianismo, utilizado por Benjamin, sobre o qual nos deteremos adiante, está implicado na motivação do fenômeno trágico que, por ter em seu horizonte a ideia de redenção, levaria o conflito a uma transformação. Veremos no entanto, que tal transformação não implica em uma superação ou apaziguamento do conflito trágico.

O que caracterizaria nosso panorama contemporâneo como uma hipérbole desse estado trágico e moderno, descrito por Williams, seria a condição permanente de exceção de nosso dia a dia hipermoderno e brasileiro:

Características de atraso em relação à norma-padrão não significavam um simples desvio ou exceção, pronto a ser superado por uma "reviravolta iluminada", mas, sim, parte constituinte e indispensável à reprodução da ordem capitalista global. O "progresso" já estava em marcha, e a condição de subdesenvolvimento era já o próprio futuro no presente, reincorporando em novas formas aspectos aparentemente insuperáveis do passado. Os meninos vendendo alho e flanela nos cruzamentos com semáforo não são a prova do atraso do país, mas de sua forma atroz de modernização. (SCHWARZ, 2012: 264)

Alma Hiperbólica, dramaturgia de um corpo melancólico mergulha neste vazio, neste estado - físico e social - de exceção hiperbólica, entendendo-o como fonte de linguagem deste corpo, na 
medida em que reconhecemos sua sombra trágica. Esta tragédia diz respeito a um corpo comum, coletivo, e é constituída em um processo histórico. No entanto, a tradução de um estado sintomático social - este vazio - em linguagem ou corporeidade melancólica, exige um trabalho (Arbeit), no sentido usado por Freud propriamente, ou seja, no sentido de elaboração ou perlaboração (Durcharbeitung) ou ainda, no sentido de "trabalho de luto" (Trauerarbeit) (GAGNEBIN, 2009: 105) ${ }^{13}$.

Eu hoje olho a Lua na tela do meu computador. Detenho-me em seus buracos, em seus vazios, em suas sombras. Quantas palavras estão contidas neste vazio? Quantas vozes estão neste buraco, dentro daquilo que não podemos ver, dentro deste vazio espacial? Quando olho para minha trajetória como artista da dança, foi sempre esse vazio que me atraiu, este mistério cujos limites parecem ultrapassar o que nossa limitada razão ou vida individual e privada pode alcançar.

A sombra melancólica que acompanha a hipermodernidade (com seus campos de concentração, genocídios e a exclusão contínua de milhões de seres humanos) revela que nossa tragédia física e social tornou-se a "regra". Contrário a esse efeito de alienação subjetiva, este corpo melancólico atesta e reconhece a tragédia hipermoderna em sua esburacada subjetividade, em uma tentativa permanente de libertação das histórias individuais e coletivas de seu farsesco progresso linear. Reconhecer essa tragédia é uma primeira ação em vista de uma nova anatomia da história e do corpo. Para que enxerguemos esta sombra histórica - presente em nossos próprios corpos - é preciso ao mesmo tempo sermos contaminados por ela e negá-la, colocando-nos em

\footnotetext{
${ }^{13}$ GAGNEBIN, Jeanne Marie. Lembrar escrever esquecer. São Paulo: Editora 34, 2009.
} 
experiência de contradição melancólica, princípio motor do que chamei na conclusão desta pesquisa - de uma corporeidade da ausência.

Alma Hiperbólica, dramaturgia de um corpo melancólico, toma este corpo como sujeito inerentemente histórico e político. $\mathrm{O}$ sujeito histórico não está separado do sujeito estético. Esse corpo melancólico toma distância do mundo para que possa negá-lo e contestá-lo, em vista do exercício de um sujeito histórico - estético.

Vejo aquela tíbia esquerda como se fosse a Lua e seu vazio como um dos buracos lunares. Opera-se aqui uma tradução fundamentada em um limiar de minha tíbia e a Lua, uma passagem, ora metonímica, ora hiperbólica, entre "minha perna" e um contexto histórico-social, religando duas instâncias que aparentemente se encontram cindidas entre si: corpo privado e corpo comum, partilhado, a Lua. O movimento proposto pela hipérbole é o de maximizar a realidade, de tornar o que parece invisível, visível, de tornar um corpo cotidianamente anestesiado em um corpo estranho, desnaturalizando nossa miséria e ampliando nossa visão sobre ela, no sentido de desnormatizar nosso estado de exceção, de vermos o ordinário através de uma lente de aumento, percebendo assim que o vazio de uma tíbia (de um indivíduo) é também o vazio do sujeito de uma história social. ${ }^{14}$ Levando esta hipótese para a própria forma desta escrita, o leitor verá que transito entre a primeira pessoa do singular (eu) para a primeira pessoa do plural (nós), ao longo da dissertação.

\footnotetext{
${ }^{14}$ Maria Rita Kehl (1999:104), partindo da distinção entre indivíduo e sujeito, estabelecida por Alain Renault em $O$ Indivíduo (1998), nos diz que "O primeiro, tributário do ideal individualista de independência - centramento em si mesmo, negação da dívida, valorização narcísica do $e u$; o segundo, herdeiro do princípio humanista de autonomia - emancipação em relação a qualquer autoridade divina, transcendente, mas reconhecimento do laço social como fundamento do que é propriamente humano em cada um. Sujeitos autônomos, e não indivíduos independentes (...)".
} 
A Lua, o corpo, estão cheios destes vazios melancólicos. Esta pesquisa se faz das faíscas de luz que parecem surgir deste vazio que é também "vão", passagem. Nossa civilização capitalista hipermoderna buscou olhar diretamente para a luz, tornando-se, por isso mesmo, cega, privada de sua visão, privada da potência melancólica que lhe permite ver sua sombra, seu vazio hiperbólico, pois ao tomar consciência deste estranho mistério também se depara com a claridade de sua ruína civilizatória. Entre outros caminhos, parece ser a partir do trabalho com essa ruína que poderíamos encontrar a própria potência de resistência e contestação de nosso estado de exceção, de abatimento e cegueira partilhada. Interessa-nos pesquisar a linguagem que pode ser elaborada neste processo de tradução do vazio melancólico em corporeidade.

No decorrer da dissertação, procuro elaborar e refletir sobre o processo de criação do solo de dança Anatomia da Melancolia experiência I, apresentado em outubro e novembro de 2015, no Sesc Pompéia em São Paulo. A análise dessa peça constitui uma espécie de fio condutor presente em todo o discurso e articulações teóricas da dissertação.

A bibliografia pesquisada para a criação do espetáculo foi fundamental tanto como material para a escrita desta dissertação, quanto como material de ensaio e de criação de Anatomia da Melancolia experiência I. Utilizamos o conceito de material tal como sistematizado por Theodor Adorno em sua Teoria Estética:

De acordo com uma terminologia já quase generalizada nos gêneros artísticos, se chama assim aquilo que se dá forma. O material não é o mesmo que o conteúdo. (...) Pelo contrário, o material é aquilo com que os artistas jogam: as palavras, as cores e os sons que se lhes oferecem, até chegar a conexões de 
todo o tipo e a procedimentos desenvolvidos para o todo; portanto, também as formas podem ser materiais, tudo o que se apresenta aos artistas e sobre o que eles têm que decidir. (ADORNO, 2004: 199)

A obra Anatomia da Melancolia de Robert Burton (1621), que deu nome e constituiu um dos materiais de pesquisa do solo realizado, inicia com as causas da melancolia, "Delírio, frenesi, loucura; Solidão e ócio; A força da imaginação", segue com a descrição dos paliativos para aliviar o sofrimento, "alegria, boa companhia, belos objetos...", para ao final abordar a melancolia amorosa e a melancolia religiosa.

A empreitada de Burton só foi possível em uma época em que a melancolia era entendida não como uma doença, mas como um fenômeno da cultura. O texto seminal de Aristóteles, contido no capítulo XXX da sua Problemata, já continha uma reflexão sobre a capacidade criativa do melancólico atribuída à instabilidade que o impele a expandir sua alma em todas as direções do universo, aspecto que se relaciona mais uma vez à ideia de hipérbole, de expansão, de ampliação da experiência real, como dito anteriormente: um corpo que vai aos extremos, que ultrapassa os limites do real, como se, tomando distância da própria realidade sob a forma da tristeza e do alheamento característicos do melancólico, paradoxalmente, tecesse um horizonte crítico e dialético em relação ao seu contexto, tendo como base o princípio da contradição ${ }^{15}$. A hipérbole figura como um desvio de linguagem por meio do qual este corpo critica e reinventa sua experiência melancólica, ampliando e atribuindo outros significados à realidade vivida, como se assim reencontrasse "a alma" de sua experiência atrofiada na hipermodernidade, atrofia geradora de seu característico vazio subjetivo:

\footnotetext{
${ }^{15}$ Discutiremos o princípio de contradição adiante.
} 
o melancólico se distancia hiperbolicamente da realidade para, contraditoriamente, nela se reencontrar. O desenho é o de uma hipérbole.

O corpo melancólico seria aquele cujas ações excedem a lógica comum, excedem o senso comum, a proporção, a lógica aceitável, os paradigmas subjetivos contemporâneos. A estas ações que excedem e ultrapassam a fronteira da doxa, chamo de hiperbólicas, ações próprias a um corpo cuja visão e sentimentos tomam proporções igualmente imensas. Trata-se de uma corporeidade crítica, que tece um desvio, distanciamento para contemplar o seu contexto de fora, de modo hiperbólico (fora da proporção do "real"). Desviando-se da lógica e medidas de proporcionalidade e ordem, esse corpo acaba por experimentar ações extraordinárias (que excedem o ordinário). Esta alma/ação hiperbólica parece traduzir e elaborar sua angústia, deslocando este corpo e retirando-o da paralisia.

O "esvaziamento da alma", o sentimento de não pertencimento, de vazio e prostração do melancólico, passa a ser um vazio preenchido de potência hiperbólica, potência de desvio e ressignificação de sua própria condição. A hipérbole opera como um olhar desviante sobre a realidade, como um procedimento (e figura de linguagem) de estranhamento, de desvio do mundo para vê-lo criticamente, de forma "aumentada", desnormatizando nosso estado de exceção, desnaturalizando nossa cegueira: desvio necessário para que possamos ver nossa tragédia e miséria de experiência como algo abusivo e violento, enfim, como um estado de exceção hiperbólico, tanto físico quanto social.

Se de um lado a melancolia pode ser entendida como o sintoma inevitável de um trauma e de um esvaziamento psíquico e mesmo criativo, de outro contém a memória (rastro) de seu objeto perdido, 
consciência e potência estas que podem disparar o ato de criação e ressignificar o próprio corpo melancólico. Diante de um mundo assolado por ruínas sociais e subjetivas, quais seriam os procedimentos criativos e de resistência às formas de poder e de controle hegemônicas? Ao dizer que o corpo melancólico é um hiperbólico vazio - marcado por uma falta de sentido de sua experiência no mundo - vazio que assume proporções extraordinárias, podemos dizer, contraditoriamente, que ele está preenchido até a borda pela memória e pela história deste mundo, ocupado por um aglomerado de fragmentos e ruínas subjetivas; ou ainda, que ele contém a visão daquilo que foi perdido, que vê os rastros da destruição. Onde estão os vestígios da história de nosso corpo social? Poderíamos talvez encontrar algumas pistas para essa pergunta a partir da corporeidade melancólica e de sua elaboração? Entendo aqui uma dramaturgia melancólica como a elaboração ensaística dessa corporeidade, ambas inscritas e escritas no corpo.

Talvez seja na vastidão do espaço vazio, melancólico, que poderemos encontrar um outro sentido para nosso corpo histórico esquecido, este nosso eco contemporâneo. Pesquisar esse vazio é preenchê-lo de sentidos que podem rememorar o passado e, desse modo, refletir e resistir à órbita autômata de nossa hipermodernidade. A ideia de melancolia é valiosa aqui não apenas por sua materialidade psíquica e física, mas também como alegoria de uma ruína subjetiva, corporal e social. Como essa ruína - aquilo que sobrevive ao trauma - pode se transformar em linguagem deste corpo? Tomamos aqui a ideia de corporeidade e de dramaturgia como materiais inerentemente históricos e 
políticos $^{16}$, dado que o sujeito histórico não está separado do sujeito estético.

Problematiza-se aqui a dissociação do corpo na hipermodernidade, cindido entre sujeito privado e sujeito público, entre trabalho manual e intelectual, entre capital e trabalho, poética e política. Procura-se tencionar as fronteiras entre estética e história, conteúdo e forma dramatúrgica, corpo e sujeito, corpo e alma, texto escrito e corporeidade, palavra e corpo, separações que parecem sustentar certa dicotomia e dissipar outras ordens possíveis para se pensar e dançar nossa hipermodernidade. A inquietação desta pesquisa repousa - e agitase - sobre a potência de uma linguagem que opere no limiar das ideias citadas acima, limiar esse que advém dos - hiperbólicos - estados físicosociais de exceção de um corpo melancólico. Não seria a melancolia a manifestação de uma cisão trágica que marca a modernidade e a atual hipermodernidade? Como pensar a forma artística de um espetáculo de dança enquanto necessidade que emerge da matéria histórica? Como pensar a forma como linguagem estético-social, linguagem do limiar que não suponha as fronteiras entre esses "departamentos do pensar"?

\section{HIPÉRBOLE NEGATIVA}

Tomando-se o corpo do artista como um microcosmo de um corpo social, tal corpo seria capaz de revelar e, ao mesmo tempo, resistir

\footnotetext{
${ }^{16}$ Se, então, "a formação dos cinco sentidos é um trabalho de toda a história do mundo até aqui" (MARX, 2004:110), e por "formação dos cinco sentidos" pode- se compreender todo o processo de formação dos seres humanos e do "sentido humano correspondente" a esta humanidade, cada nova geração de seres humanos, portanto, herda (socialmente) toda a história do mundo até o momento de seu nascimento e formação e a ela dá continuidade, a seu modo, ainda que dentro das bases e limites colocados por sua época e situação históricas concretas. Esse princípio parece fundamental à obra de Walter Benjamin e a esta dissertação.
} 
a este sistema ético e estético no qual se insere? O presente estudo além de buscar desvelar as contradições do universo melancólico, subjetivo, social, debruça-se sobre um certo corpo que procura ressignificar essa condição dada anteriormente, como resistência à mesma. Interessou-nos investigar uma corporeidade que nascesse da relação dialética ${ }^{17}$ entre o material teórico estudado e a experiência cênica colocada em prática. A pesquisa não teve a pretensão de realizar ou concluir um diagnóstico sociológico, nem tampouco fundar uma metodologia fixa, mas vislumbrou lançar um feixe de luz sobre um corpo que pode ser reflexo de uma melancolia global, tomando-se a alegoria do "excesso de bílis negra"18 do corpo melancólico como um sinal de incêndio e potência contestatória de ação e reação em ato criativo.

Em suma, a melancolia, no presente estudo, pode ser considerada como uma espécie de condição social contemporânea, ligada a um certo desencanto em relação à civilização capitalista e que, ao mesmo tempo,

17 “Consideremos o problema da dialética como crítica da unilateralidade. Unilateralidade significa pensar em termos absolutos, quer dizer, encarar os problemas de maneira metafísica. Quando se trata de apreciar o nosso trabalho, aprová-lo inteiramente ou negá-lo em bloco é agir de modo unilateral. (...) Para o nosso trabalho, a aprovação total é tão falsa como a negação total. (...) É naturalmente difícil para cada um de nós evitar completamente o ponto de vista unilateral. Uma pessoa parte sempre da sua própria experiência quando examina e trata um problema, para dar uma opinião, e é por vezes difícil subtrair-nos totalmente à opinião unilateral. Mas, não será que devemos exigir que se renuncie pouco a pouco ao exame unilateral dos problemas, para que se tenha uma visão completa das coisas? (...) Encarar os problemas de maneira unilateral é violar a filosofia dialética. (...) O método analítico é dialético. Por análise entende-se a análise das contradições das coisas e dos fenômenos. Sem conhecer bem a realidade da vida, sem compreender verdadeiramente as contradições em causa, é impossível fazer uma análise acertada. (...) A política 'Que cem flores desabrochem, que cem escolas rivalizem' dá garantias novas para o aprofundamento do pensamento e da arte. (...) 'Que cem flores desabrochem' é um meio para desenvolver a arte, e 'Que cem escolas rivalizem', um meio para fazer avançar o pensamento. A verdade desenvolve-se na confrontação. É o desenvolvimento através da luta dos contrários, o desenvolvimento dialético das coisas" (TSE-TUNG, 1979: 516-519).

${ }^{18}$ Segundo a medicina hipocrática, o melancólico se caracteriza por um excesso de bile negra no corpo. Ver mais a esse respeito no Capítulo 1. 
nos desperta para a emergência de uma outra realidade histórica e econômica, apontando, assim, para a possibilidade de um corpo de resistência, capaz de transformar nossa subjetividade hipermoderna. A investigação de um corpo estético-social de resistência e, em última instância, político, parte, nesta pesquisa, da investigação dessa corporeidade melancólica.

Tal corporeidade pode ser definida como uma hipérbole negativa, ou como uma constelação de contradições. Partimos dos conceitos de contradição, formulado por Hegel, e de negativo, tal como formulado no ensaio Dialética Negativa, de Theodor Adorno.

Hegel concebe a história humana como um processo racional original - o processo dialético - movido por contradições: na história, a contradição não é mais o que deve ser evitado, mas, ao contrário, transforma-se no próprio motor do pensamento e da realidade, ao mesmo tempo em que é o motor da história. A lógica hegeliana difere da antiga mediante a negação do princípio de identidade, tal como formulado por Parmênides e por Platão, e de contradição, tal como esta última era vista na filosofia de Aristóteles. Hegel põe a contradição no próprio núcleo do pensamento e das coisas, simultaneamente. O pensamento e o mundo tornam-se puro devir, deixam de ser estáticos e procedem, avançam e recuam, por meio de contradições múltiplas e infinitas.

Levando a dialética hegeliana às suas últimas consequências, Adorno insurge-se inicialmente contra o princípio de identidade, assim definido por Aristóteles na Metafísica (Livro XII, 10, 1075a29-b13):

(...) todos os filósofos afirmam que as coisas se geram dos contrários. Mas nem a afirmação "todas as coisas" nem a outra "dos contrários" são exatas; e eles também não dizem como derivam dos contrários as coisas que efetivamente admitem os contrários: de 
fato, os contrários não são afetados um pelo outro. Para nós, a dificuldade se resolve facilmente, admitindo a existência de um terceiro termo. (ARISTÓTELES, 2002: 581)

Para Adorno, o princípio de identidade, desde Aristóteles perverte a filosofia dialética, contaminando-a com os padrões de movimento mecânico da lógica formal: "a dialética negativa coloca o idêntico sob suspeita. Sua lógica é uma lógica da desagregação: da desagregação da figura construída e objetivada que o sujeito cognoscente possui de início em face de si mesmo. A identidade dessa figura com o sujeito é a não verdade". (ADORNO, 2010: 127)

Na Dialética Negativa, a redução do trabalho humano ao conceito universal abstrato do tempo médio de trabalho, é originalmente aparentado com o princípio de identificação. Esse princípio tem na troca o seu modelo social; por meio da troca, os seres singulares não-idênticos se tornam comensuráveis, idênticos para o comércio entre si. A difusão deste princípio transforma o mundo em algo idêntico, em ideologia.

Adorno se mostra contra a ideia de síntese, base da dialética identitária "do terceiro termo", que Aristóteles descreve na Metafísica. A síntese seria criticável não como um ato particular de pensamento que recolhe em sua relação os momentos cindidos, mas como ideia diretriz e suprema. Enquanto consciência da não-identidade através da identidade, a dialética negativa transforma categorias apenas justapostas em momentos dos quais nenhum é sem o outro: o conceito de negativo ganha, assim, o significado de oposição à identidade isolada, negar um termo significa relacionar-se com ele, fazendo com que não exista sem o seu outro, ideia sobre a qual nos deteremos no primeiro capítulo desta dissertação. 
Na dialética negativa nada é pura e simplesmente por si, mas é em si seu outro e está ligado a um outro: "aquilo que é, é mais do que ele é" (Idem). Esse mais não lhe é anexado de fora, mas permanece imanente a ele enquanto aquilo que é reprimido dentro de si. Diferentemente da dialética hegeliana, essa relação com o outro, constituidor do em-si, geraria não uma lógica que progride a partir de conceitos e por etapas até um conceito superior e universal - a síntese -, mas esses conceitos operam em relação de negação recíproca, em uma constelação. Essa concepção nos ajuda a compreender a ideia de história nesta pesquisa: a história está no corpo e fora dele, "ela é algo que o engloba e em que ele tem seu lugar. Perceber a constelação na qual a coisa [o corpo] se encontra significa o mesmo que decifrar aquilo que ela porta em si enquanto algo que veio a ser." (ADORNO, 2010: 142).

O conhecimento deste corpo em sua constelação é o conhecimento do processo histórico que o constitui. A constelação de conceitos que forma esta dissertação será organizada em busca de um desenho estelar capaz de dar forma à corporeidade melancólica: tal constelação assume as faces da contradição e da negatividade (dialética negativa, ausente de síntese) e pode ser observada na descrição dos capítulos que seguirão.

A peça Anatomia da Melancolia - experiência I é composta por três fases. A primeira etapa do solo trata justamente das contradições e negações: as partes do corpo se deslocam isoladamente, independente do resto do corpo, o corpo é tragado pela gravidade, não consegue se mover, ao mesmo tempo que tenta resistir à mesma, encadeando uma dinâmica contraditória entre prostração e resistência, corpo mobilizado pelas oposições entre quente e frio, abatimento e fúria, ação desenfreada e inação - o corpo está em uma tentativa ininterrupta de aniquilação do 
ego $^{19}$; a segunda etapa do solo trata dos rastros e da memória soterrada sob os escombros, sua fala é entrecortada a todo tempo, interrompendo a sequencialidade de seu pensamento (que portanto não se completa); do mesmo modo, um gesto começa e paralisa no meio de sua execução, interrompendo a continuidade harmônica de seu movimento e permanecendo apenas como um rastro no espaço, o gesto desaparece e apenas seu eco continua como que suspenso no ar e, finalmente, o terceiro momento do solo trata da revolta e sobrevivência do corpo melancólico: esse respira infinitamente, seus olhos - tal como os do "anjo da história" benjaminiano - contemplam o passado, a própria dramaturgia que acaba de "executar", ou melhor, a própria dramaturgia que, tal como um rastro de memória, acaba de emergir desse corpo, como um passado que, inevitavelmente, o atravessa no presente. Esse corpo melancólico é reflexo e eco de um todo, de uma história social partilhada; é a metonímia de um corpo social e histórico e, ao mesmo tempo, sua alegoria e hipérbole.

Ao final, esse corpo melancólico está mergulhado sob uma poça de bile negra, evidenciado que, apesar de tudo, sua experiência é indestrutível: esse corpo sobrevive, ainda que esteja completamente "sujo", contaminado pela bile negra que escorre da história (e do chão do cenário), de seu passado, de sua própria trajetória cênica e histórica. Esses três momentos do solo correspondem, respectivamente, aos três capítulos que compõem esta dissertação: Capítulo 1: Contradição

\footnotetext{
19 "Neste eixo, o corpo melancólico é colocado numa dinâmica mortífera indo de sua completa negação corporal, também conhecida como síndrome de Cotard (1997), até sua negação completa no ideal inalcançável também conhecido por anorexia. Tanto em um quanto em outro, o corpo é aniquilado. Tanto em um quanto em outro, só resta o ideal inatingível." (BERLINCK in. BURTON, 2011, v. 1: 9).
} 
manifesta; Capítulo 2: Rastros e imagem dialética; Capítulo 3: Mnemosyne sobrevivente.

No primeiro capítulo, tento mostrar as origens do esvaziamento subjetivo que caracteriza o corpo melancólico. A contradição caracterizaria o passado que constituiu esta corporeidade melancólica. No segundo capítulo, debruço-me sobre o processo de recriação de sua história a partir dos rastros deixados no vazio e que ocupam o corpo melancólico; os rastros indicam um trabalho a ser feito, no presente dessa corporeidade. No terceiro capítulo procuro ler esta corporeidade melancólica como uma espécie de "mnemosyne sobrevivente", a partir do procedimento de montagem do Atlas Mnemosyne de Aby Warburg. Finalmente, na conclusão, tento compreender como, da relação entre passado e presente, o trabalho a partir da melancolia elabora uma corporeidade da ausência, que se forja da "potência do vazio melancólico", apontando para uma possível redenção desse corpo e não para sua aniquilação. Nessa corporeidade, a melancolia - estado de exceção anímico-físico-social - transforma-se em potência de linguagem (embora sem síntese, inconclusa), como ação de resistência e contestação desse corpo na história. A trajetória da dissertação espelha, reitero, a própria dramaturgia - dialética e constelar - criada em Anatomia da Melancolia - experiência I, laboratório prático desenvolvido e apresentado ao longo desta pesquisa.

Incluo como anexo, ao final desta dissertação, o dvd do espetáculo, assim como o texto dramatúrgico criado. Recomendo que o leitor, de tempos em tempos, proponha-se a breves suspensões na leitura da dissertação e lance um olhar sobre esses documentos, como um estrangeiro que passeia sem destino por uma cidade desconhecida, embrenhando-se em seus becos e buracos, ou como quem folheia, de 
forma mais ou menos irresponsável, os atlas de uma antiga biblioteca encontrada.

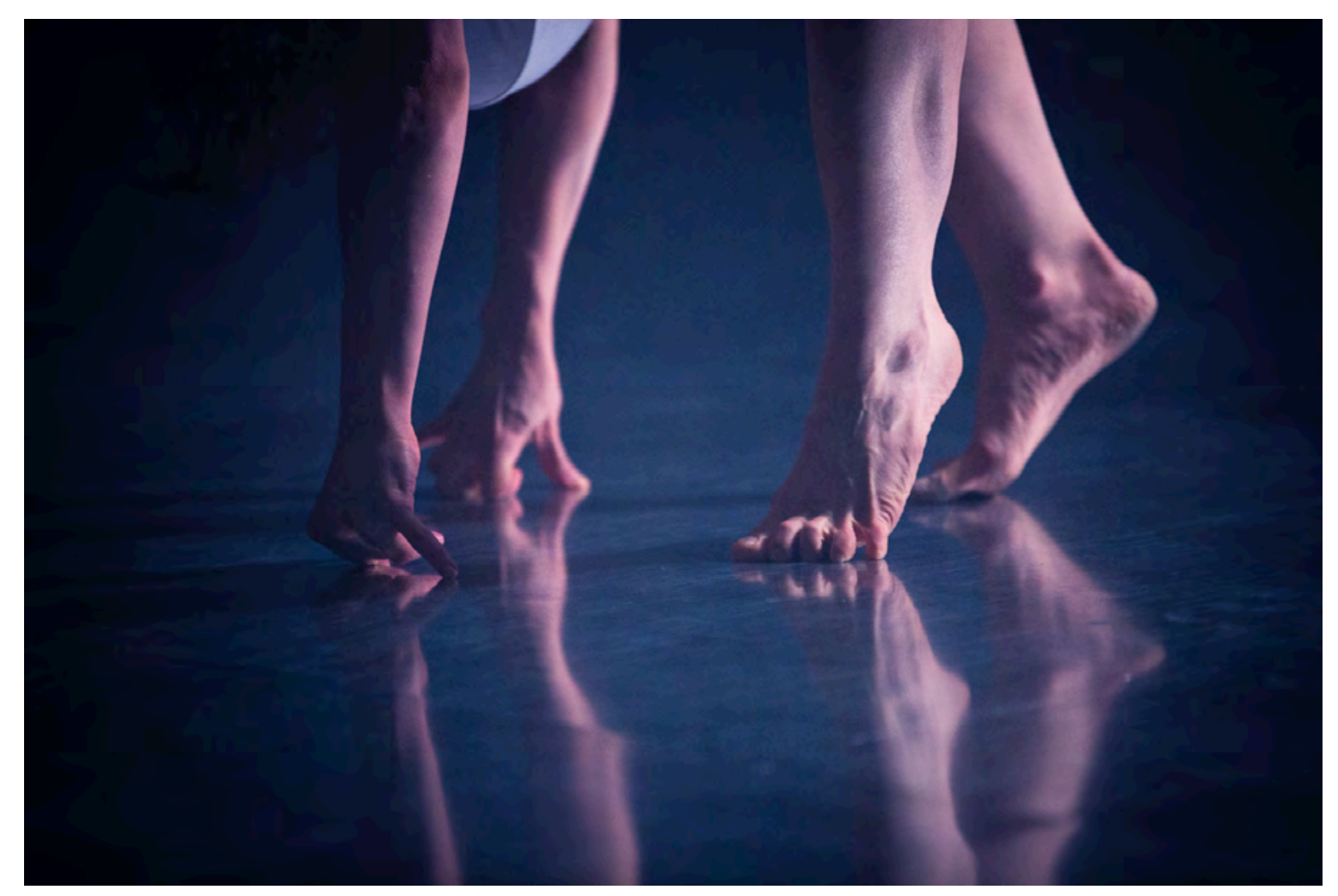

Imagem 1. GRAVIDADE. Anatomia da Melancolia - experiência I (2015). Foto: Otávio Dantas. 


\section{CAPÍTULO 1}

\section{CONTRADIÇÃO MANIFESTA:}

O corpo melancólico como sintoma do trauma e como potência de resistência

\section{MELANCOLIA}

Sobre o que estão pendidos esses personagens? Algumas vezes sobre o vazio, ou sobre o infinito de alhures. Às vezes sobre signos nos quais o pensamento encontra os traços de um outro pensamento.

Jean Starobinski.

Bastante anterior ao conceito psiquiátrico do termo, a melancolia é, desde Homero, uma cólera ligada à existência humana, podendo ser vista como um estado de recusa de tudo que parece não ser justo ao homem, ou ainda, como sintoma da consciência de nossa miséria. Em Origem do drama trágico alemão (2013) 20 de Walter Benjamin, a acedia melancólica refere-se ao sentimento de um "mundo vazio" em que as ações humanas são privadas de todo o valor. A desvalorização da experiência da vida, para Benjamin, conduziria ao fatalismo que está na origem da acedia, da "indolência do coração" do melancólico. Em Alma Hiperbólica, a ideia de melancolia é tomada tanto como um estado do corpo, como alegoria de uma condição existencial, cultural e social.

A palavra melancolia, no Ocidente, designa uma estrutura de

\footnotetext{
${ }^{20}$ A obra foi publicada pela primeira vez em 1928.
} 
sensibilidade que caracteriza o sujeito que se vê em posição excêntrica frente à norma de sua época. Da Grécia homérica até o romantismo, passando por Aristóteles e pela crise do Renascimento, o melancólico era considerado como um ser de exceção, sujeito à alternância entre momentos de inspiração poética e ataques de fúria ou de inapetência pela vida. Segundo Jackie Pigeaud ${ }^{21}$, citando Burton, a reflexão sobre a melancolia tem sido, desde Aristóteles, indissociável da pergunta sobre a criação estética, já que se relaciona sempre com uma experiência subjetiva e anímica: "Todo homem, como afirma Burton, tem razões para ser infeliz. Nesse sentido, todo homem é, necessariamente, um melancólico transitório. Mas permanecê-lo depende do temperamento". Para Pigeaud, a importância de Robert Burton - autor de A Anatomia da melancolia - residiria, também, em ter afirmado que a história é o melhor "fermento da melancolia": "De César à guerra civil francesa, afirma Burton, não há senão motivos para chorar. (...) Na verdade, o que corre o risco de se introduzir em nós quando contemplamos o mundo é a dúvida sobre sua racionalidade. O absurdo alimenta então o desespero". (PIGEAUD, 2009: 131)

Freud rompeu com essa tradição ao utilizar o significante melancolia para inaugurar uma nova explicação, psicanalítica, para a chamada psicose maníaco-depressiva. Ao trazer-lhe para o campo da psicanálise, Freud apartou-se da longa tradição de pensamento que articulava o melancólico à cultura e à criação artística.

O humor melancólico, de acordo com a teoria humoral ${ }^{22}$ da

\footnotetext{
${ }^{21}$ Jackie Pigeaud (1937-2016) foi filólogo, latinista e historiador da medicina. Autor, entre outras obras, de Metáfora e Melancolia: ensaios médico-filosóficos (2009).

${ }^{22}$ A Teoria humoral concebe que o organismo é constituído por quatro elementos (quente, frio, seco e úmido) e por quarto humores: sanguíneo (sangue), fleumático (fleuma), colérico (bílis amarela) e melancólico (bílis negra). Para cada humor ou
} 
Medicina Antiga (ou hipocrática), advém de um excesso de bile negra (melaina cholé) no corpo, temperamento que na astrologia estaria sob a regência de Saturno. Em seu prefácio à edição brasileira de Anatomia da Melancolia, Manoel Tosta Berlinck (2011) define que "a atividade melancólica é um desesperado esforço possuindo um claro sentido vertical, em busca de um ideal jamais alcançado. Ideal que se alcança não é que não seja ideal". É ideal concreto, possível, meta de um trabalho psíquico e, por isso mesmo, passageiro.”. No entanto, para o autor, não se trata de qualquer ideal: "O ideal melancólico, por sua vez, é inatingível. É manifestação da melancolia, ou seja, é razão da tristitia e não saída”. A melancolia seria, portanto, o estado de um corpo "cuja forma coincide com a morte do próprio corpo. O melancólico sabe, no âmago de si, que nenhum esforço, nenhum dispêndio de energia, irá modificar essa situação, essa inércia.” (BERLINCK, 2011: 7).

Walter Benjamin, cuja leitura da poesia de Baudelaire marcou definitivamente a recepção contemporânea da obra deste poeta, teria sido o último dos pensadores modernos a tomar a palavra melancolia no sentido pré-freudiano, ao relacionar o desencanto do melancólico diretamente ao efeito de um desajuste ou mesmo de uma recusa quanto às condições simbólicas do laço social. O melancólico benjaminiano pode ser entendido como um sujeito que se sente apartado da dimensão pública no que diz respeito à hegemonia dos mandatos éticos e morais agenciados pelas instâncias de poder.

Segundo Benjamin, Baudelaire, por meio de sua poesia, teria emprestado uma forma alegórica à modernidade: em sua obra, a matéria da melancolia é a relação do indivíduo com o espaço público da cidade, 
marcado pela perda do pertencimento a formas comunitárias de convívio que desde a modernidade teriam sido, aos poucos, destruídas. O romantismo tardio de Baudelaire - o último dos poetas românticos e o primeiro dos modernos - é interpretado por Benjamin como uma tentativa de superação do desencanto melancólico causado pelo fracasso das revoluções, pelo desalento do indivíduo diante de um tempo brutal cuja superação não se anunciava em nenhum horizonte.

Este olhar para a destruição e para a ruína que caracterizaria a subjetividade melancólica geraria a eterna sensação de desajuste e de inadequação do corpo em relação a si mesmo e ao seu contexto. Este sujeito ao qual me reporto, não supõe uma crença no indivíduo como instância soberana do saber, erigido e dominado por um eu existencial e nuclear, por um corpo "uno" da razão; trata-se, antes, de entender esse corpo, simultaneamente, como alegoria e ator de uma subjetividade social; esse sujeito melancólico, existe e resiste no limiar do indivíduo e do universo social. Não partimos, portanto, da ideia de um sujeito cartesiano (cogito), absoluto, do indivíduo moderno tal qual um uno indivisível e protegido por uma abstração conceitual. O "eu” melancólico pode ser compreendido como um sujeito do limiar, conceito sobre o qual nos deteremos ao longo da dissertação. Mesmo o corpo do indivíduo (o corpo que dança em cena, por exemplo) é compreendido aqui como parte de um corpo social, coletivo, participante de um "macro-universo", não existindo senão no limiar particular - universal.

\section{CORPO DO LIMIAR}

A partir de uma citação de Benjamin, podemos definir a linguagem e corporeidade melancólica, sobre a qual me detenho nesta dissertação, 
como uma zona artística de limiar: "O limiar deve ser rigorosamente diferenciado da fronteira. O limiar é uma zona. Mudança, transição, fluxo estão contidos em seu significado. (...) Morada de sonho." (BENJAMIN, 1989: 512-513).

Em oposição à estética tradicional normativa, que sempre caracterizou-se por estabelecer fronteiras entre as linguagens, interessanos abordar a corporeidade melancólica a partir do $\operatorname{limiar}^{23}$ da dança, teatro, literatura, sociologia, filosofia, psicologia e história. Desse modo, colocamos em questão a ideia de separação entre os "campos de conhecimento", o que nos permite defender uma corporeidade melancólica como uma constelação de todas essas áreas e linguagens em trânsito. A presente pesquisa delineia-se neste devir entre as linguagens nesta zona desconhecida em que a dança não é dança, o teatro não é teatro e a sociologia não é sociologia, mas são todas expressões de passagem, que operam em limiar.

Deseja-se aqui refletir sobre as ações físico-dramatúrgicas de um corpo melancólico que podem surgir dos intervalos, dos interstícios, dos confrontos e da coexistência destas linguagens. A dramaturgia analisada aqui, assim como a história, emerge de múltiplas passagens, transições e metamorfoses; tanto a história quanto a obra que aqui analisamos não se definem, portanto, como reunião de eras ou linguagens sequenciadas, linearmente uma após a outra, mas descrevem trajetórias em

\footnotetext{
${ }^{23}$ Interessa-nos considerar o limiar descrito por Benjamin em perspectiva com a reflexão da pesquisadora Ileana Diéguez (2009). Segundo Diéguez, o limiar é "um estado resguardado e extra-cotidiano", um "estranhamento do estado habitual da teatralidade tradicional e como aproximação à esfera cotidiana" (DIEGUEZ, 2004: 03). A autora nos diz que "refletir sobre as teatralidades liminares não implica apenas considerar seu complexo hibridismo artístico, mas também considerar as articulações com o tecido social no qual se inserem" (Ibidem: 04). O estudo de uma corporeidade melancólica nesta pesquisa pretende partir destas duas abordagens acerca do conceito de limiar.
} 
constelação ${ }^{24}$, que operam transformações, substituindo supostas fronteiras que "apartam" por portais que criam outras possibilidades de expressão artística e de compreensão da realidade e de nosso corpo histórico.

Este conceito ampliado de limiar também nos é caro para orientar esse estudo: encaramos a história não como uma sequência linear de acontecimentos divididos em séculos, mas como épocas que se justapõem no momento presente, ou seja, épocas cujos intervalos não se descrevem como fronteiras temporais, mas como limiares, épocas que operam simultaneamente e de modo constelar no presente, em um Agora que, para Benjamin, conjuga passado e presente na compreensão da história. Assim, ao falarmos do corpo a partir de um ponto de vista histórico, falamos de um corpo cujo Agora está preenchido de épocas passadas que se relacionam em uma zona de limiares históricos e estéticos.

No vocabulário filosófico clássico, o conceito de fronteira, de limite, constitui uma metáfora essencial na tentativa de designar uma dupla operação: desenhar um traço ao redor de algo para the dar uma forma bem definida e, portanto, evitar que esse algo, por assim dizer, derrame-se a um infinito onipotente. A fronteira contém e mantém algo, evitando seu transbordamento, isto é, define seus limites não só como os contornos de um território, mas também como as limitações do seu

\footnotetext{
24 “Do mesmo modo que a constelação não é permanente - pois é tanto uma estrela que aparece em uma direção quanto uma outra estrela em uma direção oposta -, tampouco as linhas traçadas sobre o corpo humano, que correspondem à constelação do firmamento, são permanentes; mas elas se metamorfoseiam segundo a condução do homem." (Zohar, II, 76b) (Tradução nossa). No original: "De même que la constellation n'est pas permanente - car c'est tantôt une étoile qui apparaît dans une direction et tantôt une autre étoile dans une direction opposée -, de même les lignes tracées sur le corps humain, qui correspondent à la constellation du firmament, ne sont pas permanentes; mais elles se métamorphosent selon la conduite de l'homme" (Zohar, II, 76b). (OUAKNIN, 2010: 98.)
} 
domínio. Não por acaso, o conceito de fronteira remete a contextos jurídicos de delimitação territorial, em particular entre a cidade e o campo ou entre várias propriedades fundiárias ou, ainda, entre vários territórios nacionais. A fronteira designa a linha, cujo traço e cuja espessura podem variar e que não pode ser transposta impunemente. Sua transposição sem acordo prévio ou sem controle regrado significa uma transgressão.

O conceito de limiar, por outro lado, remete às ideias de soleira, de umbral, pertencendo igualmente ao domínio de metáforas espaciais que designam operações intelectuais e espirituais, mas se inscreve de antemão num registro mais amplo, registro de movimento, de ultrapassagem, de passagens. Na arquitetura, o limiar deve preencher justamente a função de transição, isto é, permitir ao andarilho que possa transitar de um lugar determinado a outro, diferente, ou mesmo oposto. Seja ele simples rampa, soleira de porta, corredor, escadaria, portão, o limiar não faz só separar dois territórios (como a fronteira), mas permite a transição, de duração variável, entre esses dois territórios. O limiar designa essa zona intermediária à qual a filosofia ocidental geralmente opõe tanta resistência, assim como o chamado senso comum pois, na maioria das vezes, prefere-se as oposições demarcadas e claras, por exemplo: masculino/feminino, sagrado/profano, correto/errado, justo/injusto, etc. O limiar implica assim em uma ideia de contradição, segundo a qual distintas categorias se justapõem e se contaminam.

O conceito de limiar tem para Benjamin, dois sentidos contraditórios: significa ao mesmo tempo delimitação e passagem, separação e transição. Essa definição nos ajuda a compreender, no decorrer deste estudo, a utilização dos termos corpo, subjetividade, eu, outro, sujeito histórico, história: não pressupomos a separação entre 
essas instâncias, no entanto, deve-se considerar as características próprias de cada uma delas que se relacionam em limiares dialéticos entre si.

Em Anatomia da Melancolia - experiência I, tive uma grande dificuldade: como evidenciar que, embora se tratasse de um corpo (indivíduo) em cena, a solista poderia deflagar um corpo "partilhado", coletivo? O que percebo ter descoberto como procedimento foi uma espécie de "estado de presença de exceção", algo que até então nunca havia experimentado em nenhum outro trabalho. Era como estar em cena e tentar a todo tempo "apagar-me" como corpo individual, "estando" e "não estando", sendo presente e ausente. Eu manipulava minha energia para "desaparecer" no espaço, de certo modo. Umas das estratégias foi, durante os primeiros vinte minutos do espetáculo, permanecer sentada junto ao público e - enquanto trabalhava na contradição entre "paralisia e breves espasmos", que suspendiam por um momento a inércia tediosa em que meu corpo estava - tentava "ausentar-me" e, ainda que eu estivesse apenas vestida com uma camiseta e descalça, muitos não identificavam que eu já estava na sala de espetáculo, pois estava "dissolvida" no corpo partilhado e coletivo do público.

Outro aspecto que me parece evidenciar a correspondência entre o corpo "indivíduo" a um corpo partilhado, está explícito no próprio texto escrito pelo dramaturgo ${ }^{25}$ : ora o personagem fala na primeira pessoa do singular (eu), ora na primeira pessoa do plural (nós). Além desse aspecto, o texto deixa clara a relação entre um corpo "micro" (personagem melancólico) e um corpo "macro" (universo, sistema solar), relacionando ainda diferentes épocas e eventos históricos entre si; um exemplo: o personagem "do presente" se relaciona diretamente à crise da bolsa de valores de 1929, como se ocupassem um mesmo tempo-espaço, ou seja,

\footnotetext{
${ }^{25} \mathrm{O}$ texto segue anexo ao final da dissertação.
} 
um tempo do "Agora" de Benjamin, no qual o passado se encontra com o presente em um choque de violência, em uma espécie de suspensão temporal sobre a qual falaremos mais à frente.

Esta corporeidade melancólica pode ser vista como uma parte de um todo ${ }^{26}$ e é, nesse sentido, que emprego o termo "hiperbólico": um corpo capaz de "ampliar" ou de "exagerar", em si mesmo, um sintoma e um contexto histórico para o qual já nos tornamos cegos, que nos apresenta de certo modo "apagado" em nossa contemporânea ruína hipermoderna. Ao mesmo tempo, este corpo também pode ser visto - ele mesmo - como este todo, ele não representa, mas "é" em si um todo social. Esse conceito relacional do corpo constitui uma rejeição da visão de mundo tradicionalmente atribuída a Descartes, Newton e Locke, que funda o ideal do corpo "civilizado" e "individualizado" (compreendido como uma entidade em um espaço e tempo absolutos) de boa parte do pensamento ocidental.

Estudar o corpo melancólico consiste em considerar corpos submetidos aos imperativos do mercado e transformados em verdadeiras máquinas desejantes, incapazes de satisfazer seus desejos, vivendo na nostalgia impossível de um objeto perdido capaz de reconciliar o eu e o mundo. Esta pesquisa deseja investigar este objeto esquecido, sendo este a própria história deste corpo. Investiga-se aqui a potência desta "falta" que o corpo melancólico testemunha e manifesta e para tal estudo parece

\footnotetext{
${ }^{26}$ Essa ideia remonta ao sofista Protágoras, permitindo-se ver o indivíduo como uma espécie de centro descentrado do cosmos. É de Protágoras a frase famosa, "o ser humano é a medida de todas as coisas, do que é, enquanto é, do que não é, enquanto não é". Nas Lições sobre a História da Filosofia, Hegel sustenta que os sofistas, juntamente com Sócrates, foram os pioneiros na descoberta da subjetividade, demarcando-se da anterior especulação sobre a natureza: "Enquanto que o homem, como sujeito, é a medida de tudo, a natureza não é por si mesma, senão para o meu conhecimento; a consciência é no mundo objetivo, essencialmente, a realidade que produz o conteúdo do mundo, quer dizer, o pensamento subjetivo, que não pode ser diferenciado do corpo, desempenha, nisso, uma atividade essencial." (HEGEL, 1955: 31).
} 
necessário, em um primeiro momento, nos debruçar sobre as possíveis origens e contradições históricas que forjam o que aqui chamamos de melancolia.

\section{MODERNIDADE ${ }^{27}$ E MELANCOLIA}

Iniciamos com a ideia de que a experiência da modernidade produz corpos melancólicos que são, ao mesmo tempo, objeto de abatimento de sua época - em sua inadequação em relação à mesma - e sujeito de resistência e estranhamento em relação ao seu contexto histórico-social. Para essa investigação, valho-me, sobretudo, de alguns conceitos de Walter Benjamin e da ideia de unheimlich ${ }^{28}$, como fios condutores para um pensamento sobre o corpo melancólico.

Não utilizo a ideia de um corpo pós-moderno, ainda que nossa reflexão trate de um corpo "atual”. Explico. O conceito de pós-moderno me parece oferecer um semblante ideológico acerca das

\footnotetext{
27 "A forma econômica específica que caracteriza a modernidade, em que a mais-valia não paga é arrebatada dos produtores diretos, determina a relação entre governantes e governados, pois nasce diretamente da própria produção e, por sua vez, reage sobre ela como elemento determinado (...). É sempre a relação direta entre os donos das condições de produção e os produtores diretos que revela o segredo mais recôndito, a base oculta de toda a estrutura social e, com ela, a forma política das relações de soberania e dependência, a forma específica correspondente do Estado, todas definidoras da modernidade. Isso não evita que a mesma base econômica moderna mesma do ponto de vista de suas condições principais -, devido a inumeráveis condições empíricas diferentes, apresente infinitas variações e gradações de aparência que só podem ser identificadas pela análise das circunstâncias empiricamente dadas." (MARX, 2017: 701).

28 "Em O estranho (Unheimlich), Freud (1919-1976) faz um fascinante estudo da palavra unheimlich (...). Em inglês há um termo bastante apropriado para ele - uncanny - termo negação de canny (arguto, prudente, inofensivo) que pode por seu turno significar não apenas cosy (confortável, aconchegante) como algo misterioso, dotado de estranhos poderes. Uncanny refere-se por sua vez, a algo não facilmente explicável, não-natural, não familiar e levemente assustador. O estranho é antes de tudo, algo que se tornou unheimlich por ter sido antes familiar (heimlich) (...).”. (SOUZA, 2002: 51.)
} 
problematizações históricas do corpo contemporâneo, podendo supor uma ruptura entre o "antigo" e o "atual", o "velho" e o "novo", entre o passado e o presente; como se o passado, nossa modernidade, tivesse alcançado sua conclusão, para então darmos início a um "novo" tempo, um tempo "pós". Ao longo desta dissertação, interesso-me justamente em compreender nosso presente como uma constelação de inúmeras questões que foram forjadas, desde a modernidade, e que ainda se encontram suspensas na "atualidade". Embora esta questão acerca da nominação de nossa época não participe do horizonte desta pesquisa, poderíamos talvez utilizar o termo "hipermodernidade". Segundo essa ideia, nossa contemporaneidade pode ser vista como uma modernidade elevada à enésima potência, uma época hiperbólica caracterizada por uma inflação e insuflação que leva a uma espécie de transbordamento desta mesma modernidade e, assim, ao seu próprio colapso: esse "excesso" - esta hipérbole - nos leva, dialeticamente, à anulação da própria modernidade, ao seu oposto negativo: a sua ruína.

Nesse sentido, não há um "pós", mas um outro estágio da modernidade. Frequentemente o termo "pós-moderno" pressupõe um salto temporal - e uma cisão/fronteira histórica - entre o "Outrora" e o "Agora", como diria Benjamin, desprezando os limiares históricos e as implicações da modernidade no que dizemos ser contemporâneo. Essa recusa não é inédita. Contrários à ideia de anulação do passado, pensadores como Benjamin e Giorgio Agamben, argumentam que o historicismo contém um pressuposto progressista e linear sobre a história - como se essa fosse uma sequência ou mesmo um empilhamento de acontecimentos avulsos -, colaborando para uma aparente onipotência do sujeito contemporâneo em um tempo vazio e homogêneo, em que o ontem é apagado pelo hoje. Agamben nos ajuda a refletir sobre uma 
relação dialética entre passado e presente: "é como se aquela invisível luz, que é o escuro do presente, projetasse sua sombra sobre o passado, e este, tocado por esse facho de sombra, adquirisse a capacidade de responder às trevas do agora.”. (AGAMBEN, 2009: 59-72)

Entrever esse escuro é, de certo modo, a tarefa do anjo da história, a alegoria de Benjamin que descreve o sujeito que caminha de costas em direção ao futuro, enquanto seu olhar está direcionado ao passado. A alegoria da ruína adotada por Benjamin, pode ser vista ainda como as trevas nomeadas por Agamben:

Há um quadro de Klee intitulado Angelus Novus. Representa um anjo que parece preparar-se para se afastar de qualquer coisa que olha fixamente. Tem os olhos esbugalhados, a boca escancarada e as asas abertas. O anjo da história deve ter esse aspecto. Voltou o rosto para o passado. A cadeia de fatos que aparece diante dos nossos olhos é para ele uma catástrofe sem fim, que incessantemente acumula ruínas sobre ruínas e lhas lança aos pés. Ele gostaria de parar para acordar os mortos e reconstituir, a partir de seus fragmentos, aquilo que foi destruído. Mas do paraíso sopra um vendaval que se enrodilha nas suas asas, e que é tão forte que o anjo já não as consegue fechar. Esse vendaval arrasta-o imparavelmente para o futuro, a que ele volta as costas, enquanto o monte de ruínas à sua frente cresce até o céu. Aquilo a que chamamos o progresso é este vendaval (BENJAMIN, 2013a: 14)

O "anjo da história" benjaminiano não está passivo em sua época, mas em atividade de contradição em relação à mesma, em um exercício de negação e estranhamento de seu próprio tempo. O corpo melancólico, presente em Anatomia da Melancolia - experiência I, pode ser visto como uma espécie de ruína da modernidade, corpo que contém as trevas dessa última, que existe na e da confluência de tempos, nos limiares do 
passado e do presente, temporalidade que relacionar-se-ia mais a um tempo messiânico, capaz de investir esse corpo:

O historicismo limitou-se a estabelecer um nexo causal entre os vários momentos da história. Mas um fato, por ser causa de outro, não se transforma por isso em fato histórico. Tornou-se nisso postumamente, em circunstâncias que podem estar a milênios de distância dele. O historiador que partir desta ideia desafia os acontecimentos pelos dedos como um rosário. Apreende a constelação em que sua própria época se insere, relacionando-se com uma época anterior. Com isso, ele fundamenta um conceito de presente como "Agora" (Jetztzeit), um tempo no qual se incrustaram estilhaços do messiânico (Ibidem: 20)

Partimos, assim, da ideia de que este corpo melancólico contemporâneo, tal como um "anjo da história", revela-nos as ruínas de um corpo, forjado na modernidade, composto de "estilhaços de um tempo messiânico". Não somos um outro novo, cujo passado teria sido subitamente apagado. Nossa corporeidade em ruínas atesta a continuidade da modernidade ainda que em outra fase, em sua destruição implosiva (e explosiva). Seria preciso compreender nossa contemporaneidade a partir de suas contradições internas, contradições entre as épocas, como este Agora, tal qual uma constelação de que nos fala Benjamin.

Para compreendermos o que significa o tempo messiânico mencionado por Benjamin, "podemos aqui estabelecer uma analogia com a metáfora do relojoeiro que desmonta o relógio para ver como ele funciona: no momento em que o faz, este deixa de funcionar". Para Matos (2016: 24), “esta paragem, síncope na continuidade da história, é a dialética em suspensão, que abre a possibilidade ao relógio para 
funcionar de outro modo, acertando-o pelo compasso de uma outra temporalidade". Assim como o corpo melancólico que estamos descrevendo, "pode-se desmontar um relógio para aniquilar o insuportável do tempo, mas também para se compreender melhor como funciona, para reparar o relógio defeituoso. Tal seria o duplo regime do verbo desmontar". A dimensão do tempo messiânico figura como "um salto, uma ruptura no fio da continuidade". Esta ideia da "desmontagem" está entrelaçada com a da suspensão, a "dialética da suspensão" que "desmonta" algo, que "desintegra e dá a ver o modo como as coisas funcionam, nos seus mais ínfimos detalhes, é uma imagem que faz suspender, que confunde, que problematiza o real, supondo o desconcerto e o choque." (MATOS, 2016: 24).

Este princípio do choque caracteriza justamente a violência utópica que emerge da melancolia, estado e dinâmica de exceção que desmonta a realidade que deseja compreender. Para o melancólico, esta compreensão nunca é alcançada, sua ação existe na tensão de fios contraditórios - dos estilhaços - da história, não lhe sendo cabível nenhum futuro ou síntese final, nem sequer a morte: este corpo vive em negação contínua de sua época, porém, contraditoriamente, em uma dinâmica de deslocamento e rupturas (suspensões), resiste ao seu próprio tempo, resiste à própria morte.

A ideologia contemporânea privilegia saltos históricos (em nosso próprio cotidiano) como se a vida devesse ser - obrigatoriamente baseada em uma sucessão de acontecimentos felizes, sendo todos os eventos, sentimentos, descrições e percepções de mundo, que caminham na negativa dessa felicidade estabelecida, colocados em um grande arquivo de patologias e neuroses que serão despachados em consultórios psiquiátricos, shoppings centers, aeroportos e uma série de lugares que 
nos prometem um falso e perverso "alívio" da dor, da violência e da miséria, tributárias de um sistema econômico que rege não apenas os acordos financeiros e as relações de trabalho, mas, ainda, nossas relações subjetivas, simbólicas e nossa própria constituição, tanto política quanto subjetiva:

A diversão é o prolongamento do trabalho sob o capitalismo tardio. Ela é procurada pelos que querem se subtrair aos processos de trabalho mecanizado, para que estejam de novo em condições de enfrentá-lo. Mas, ao mesmo tempo, a mecanização adquiriu tanto poder sobre o homem em seu tempo de lazer e sobre sua felicidade, determinada integralmente pela fabricação dos produtos de divertimento, que ele apenas pode captar as cópias e as reproduções do próprio processo de trabalho. (...) Disso sofre incuravelmente toda diversão. (ADORNO, 2002: 19)

Este sistema de "pseudo alívio" da angústia agrava, todavia, nossa própria dor e miséria: é nos prometido - a crédito porém com benefícios imediatos - uma pretensa eternidade e imortalidade a partir da efemeridade do poder de compra (de um par de sapatos ou de um medicamento), gerando, em decorrência, uma série de traumas no corpo que escondem a autoridade - autenticidade - de nossa angústia, sentimento que sinaliza um mal-estar em relação ao nosso sistemamundo capitalista. O problema pode ser compreendido de modo claro em uma passagem de Terry Eagleton (2003) em seu Doce Violência, a Ideia do Trágico:

O tropo do capitalismo é a ironia trágica, pois o sistema, para atingir seus próprios fins, precisa desencadear forças que são capazes de subjugá-lo. Apreender essa dupla face da época moderna, entretanto, requer o tipo de abordagem dialética que 
atualmente está em falta. (...) Das teorias contemporâneas, somente o marxismo insiste em que a modernidade representou um avanço revolucionário no bem-estar humano e, com igual paixão, que ele foi um longo pesadelo de brutalidade e exploração. Nenhum outro pensamento parece ser capaz de manter essas duas histórias sob tensão (...). Entretanto, é da necessária relação entre eles que detém a chave da modernidade. (EAGLETON, 2003: 329)

Essa "necessária relação" dialética, advinda "desta dupla face da época moderna", configura, assim, uma contradição, que é a chave para se entender este corpo melancólico, forjado no limiar da liberdade e da barbárie da exploração. Estas "duas histórias sob tensão" se tornam o material de base para a pesquisa teórico-prática desta corporeidade melancólica. Talvez estejamos à espera de um tempo messiânico que nos retirará do sentimento de vazio do mundo atual, "salvando-nos" do trauma civilizatório capitalista, de nossa condição moderna arruinada. $\mathrm{Na}$ contramão dessa expectativa, supomos um trabalho autêntico a partir de nossas trevas, o que significa considerar que esse tempo messiânico pode chegar a qualquer momento, ou ainda, que ele já está presente, cabendo a nós escutá-lo como um sussurro às nossas costas, sussurro em relação ao qual o "anjo da história" deve estar atento. Segundo Eagleton (2003): "Para ser autêntica, a cultura precisa imergir no elemento destrutivo, reconhecer essas coisas da escuridão como suas; caso contrário, ela adoecerá com a neurose que surge da repressão (...)." (Ibidem: 331).

\section{A POÉTICA DE BAUDELAIRE: NEGAÇÃO E CHOQUE}

Falamos, anteriormente, sobre o corpo contemporâneo como ruína tributária da modernidade dos séculos XIX-XX, cuja história está 
carregada de contradições. Nas palavras de Jean Starobinski ${ }^{29}$ em seu artigo Les cheminées et les clochers (As chaminés e os sinos):

A modernidade, precisemos, não reside apenas na presença da fumaça e do barulho da indústria; o que é especificamente moderno, é a justaposição do traço vertical das chaminés e o das igrejas: é o contraste e a dissonância de sua presença simultânea. A oposição se inscreve nas cores entre as <plumas amarronzadas> e os <claros carrilhões>. Mais profundamente, neste instante matinal, são dois tipos de organização do tempo que inscrevem seus sinais na paisagem: de um lado a ordem técnica da produção, da exploração e da transformação dos recursos naturais, segundo uma temporalidade na qual o homem dirige em seu benefício a sucessão das causas físicas; de outro lado, a ordem sagrada das ordens canoniais, que entoam o tempo impondo ao crente a rememoração dos momentos decisivos da história da redenção (STAROBINSKI, 1990: 26) (Tradução nossa)

A contradição entre dois tipos de organização do tempo, evidenciada por Starobinski, contradição entre o progresso e a tradição, vista na paisagem das cidades modernas, é a pedra fundamental da modernidade. Essa contradição está evidente na obra poética de Baudelaire:

Baudelaire aceita o desafio e leva o combate diretamente para o próprio terreno da mercadoria. (...) o que confere à sua descoberta um caráter propriamente revolucionário é que Baudelaire (...) se propôs a criar uma mercadoria na qual a forma de

\footnotetext{
${ }^{29}$ Jean Starobinski (Geneva - Suíça -, 1920) é médico psiquiatra, escritor, teórico e historiador das ideias e da literatura, tendo publicado inúmeros artigos e livros sobre a melancolia, tema sobre o qual se deteve mais particularmente ao longo de seus estudos. Uma de suas obras fundamentais é L'Encre de la Mélancolie (2012) publicada pela Editora Seuil (França) e pela Companhia das Letras no Brasil com o título "A tinta da melancolia" - Companhias das Letras (2017).
} 
valor se identificasse totalmente com o valor de uso, uma mercadoria por assim dizer, absoluta, na qual o processo de fetichização fosse levado ao extremo de anular a própria realidade da mercadoria enquanto tal (...), a mercadorização absoluta da obra de arte é também a abolição mais radical da mercadoria. A partir daí tem-se a desenvoltura com que Baudelaire põe a experiência do choc no centro do próprio trabalho artístico. (BENJAMIN, 2013a: 164)

Esta abolição se constitui a partir de um combate: Baudelaire recusa - nega - a mercadoria a partir da absorção da mesma em sua obra, em um movimento contraditório de afirmação, negação e enfrentamento - choque - direto com ela:

O empreendimento de Baudelaire foi o de trazer à luz, na mercadoria, a aura que lhe é própria. Procurou de uma maneira heroica, humanizar a mercadoria. (...) a alegoria de Baudelaire traz, ao contrário da barroca, as marcas da cólera, indispensável para invadir esse mundo e arruinar suas criações harmônicas (...). (AGAMBEN, 2007: 74-75)

Contrário a conceber a arte moderna a partir de uma atitude de contemplação harmônica e positivista de sua época, Baudelaire entende que essa arte deveria ser uma experiência de choc: a partir da própria imagem da mercadoria, o poeta engaja-se em um combate real entre sujeito e realidade; um corpo que "estranha" seu contexto, evidenciando um choque não harmônico entre corpo e contexto, forjando a partir desse combate uma nova linguagem e experiência artística do corpo, a partir da e na realidade. $O$ poeta não liberta a mercadoria de seu estatuto fetichizante, mas a absorve simultaneamente enquanto a nega, em um combate - choque - entre o artista e a mercadoria, dinâmica esta que fundamenta a corporeidade melancólica: trata-se de um corpo que é, ao mesmo tempo, um detrito da realidade (uma mercadoria descartada), 
quanto opera, em si mesmo, a negação desta sua condição física, existencial, política e social. Em Baudelaire, o valor da mercadoria é criticado por meio de uma nova economia poética e política:

O heroísmo de Baudelaire não consiste em se fazer defensor da multidão fascinada e consumida pelas mercadorias e pelo trabalho braçal que a aproxima e afasta do brilho das mercadorias. Consiste apenas, o que já é muito, em descrer de tal fascínio. (KHEL, 2009: 75)

Segundo Agamben (2012c), o procedimento de Baudelaire não extermina a aura ${ }^{30}$ da mercadoria, mas a multiplica em uma nova forma de autenticidade na modernidade. A mercadoria teria seu valor de troca convertido em uma nova economia que se caracteriza por um "valor de estranhamento", valor aurático aparentemente estranho à sua própria condição moderna, ao seu próprio caráter reprodutivo. Na leitura de Agamben, a aura não teria sido eliminada na modernidade e em sua reprodutibilidade técnica ${ }^{31}$, mas transformada em um novo valor que

\footnotetext{
${ }^{30}$ Por meio do conceito de aura, Benjamin procura interpretar o estado do mundo regido pelo capital e pela mercadoria. A aura - da fotografia, do cinema, dos acontecimentos históricos, de um nome - diz respeito a tudo aquilo que sabemos que em breve não estará mais diante de nós, tudo que traz consigo vestígios de um desaparecimento. Nesse sentido, a aura não se relaciona à espiritualidade ou a algo "divino", mas foi absorvida como uma forma de dominação a serviço do Estado. Do ponto de vista da história da estética, o termo "aura" recebe significado filosófico pela primeira vez na obra de Benjamin. Semanticamente a palavra origina-se na tradução do grego para o latim aura, que significa sopro, ar, brisa, vapor. Sua ilustração como círculo dourado em torno da cabeça, tal como aparece em imagens religiosas, talvez derive da identificação vulgar entre o termo grego e o latino aureum (ouro), que deu origem à palavra auréola. Simbolicamente, entretanto, ambas (aura e auréola) indicam um procedimento universal de valorização sagrada ou sobrenatural: a aura designa a luz em torno da cabeça dos seres dotados de força divina, sendo que a luz é sempre um índice de sacralização.

${ }^{31}$ Ao contrário do que afirmava Benjamin no seu ensaio A obra de arte na era de sua reprodutibilidade técnica: "O conceito de aura permite resumir essas características: o que se atrofia na era da reprodutibilidade técnica da obra de arte é sua aura. Esse
} 
rompe com aquele que correspondia à tradição para Benjamin ${ }^{32}$. Para Agamben, o que teria sido destruído é a própria tradição, não a aura em si, ou ainda, estaríamos, na modernidade, diante da aura da forma mercadoria, erigida das ruínas da obra de arte sagrada:

\begin{abstract}
Ora, ora, meu caro! O senhor! Aqui! Em um local mal afamado - um homem que sorve essências, que se alimenta de ambrosia! (...). - Há pouco estava eu atravessando o bulevar com grande pressa, e eis que, ao saltar sobre a lama, em meio a este caos em movimento, onde a morte chega a galope de todos os lados ao mesmo tempo, minha auréola, em um movimento brusco, desliza de minha cabeça e cai no lodo do asfalto. Não tive coragem de apanhá-la. Julguei menos desagradável perder minhas insígnias do que me deixar quebrar os ossos. E agora, então, disse a mim mesmo, o infortúnio sempre serve para alguma coisa. Posso agora passear incógnito, cometer baixezas e entregar-me às infâmias como um simples mortal. (BAUDELAIRE, 1997: 267)
\end{abstract}

No poema em prosa citado acima, por meio da alegoria da perda da auréola ou da aura, Baudelaire nos revela que a antiga autenticidade objetiva da obra teria sido deslocada de seu topos histórico e econômico

processo é sintomático, e sua significação vai muito além da esfera da arte. Generalizando, podemos dizer que a técnica da reprodução destaca o domínio da tradição no objeto reproduzido. Na medida em que ela multiplica a reprodução, substitui a existência única da obra por uma existência serial. E, na medida em que essa técnica permite à reprodução vir ao encontro do espectador, em todas as situações, ela atualiza o objeto reproduzido. Esses dois processos resultam num violento abalo da tradição, que constitui o reverso da crise atual e a renovação da humanidade". (BENJAMIN, 2006: 211)

32 "É curioso observar que Benjamin (...) não tenha se dado conta de que a 'decadência da aura' (...) não tinha de modo algum como consequência a 'liberação do objeto do seu invólucro cultural' e o seu fundar-se, a partir daquele momento, na práxis política, mas, ao contrário, a reconstituição de uma nova 'aura' - através da qual o objeto, recriando e exaltando, antes, ao máximo, em um outro plano, a sua autenticidade -, ganhava um novo valor, perfeitamente análogo àquele valor de estranhamento (...) através da multiplicação do original, a autenticidade se torna a cifra mesma do inapreensível." (AGAMBEN, 2012c.: 172). 
anterior para uma nova economia artística e política. O poeta prefere perder sua aura - "suas insígnias" -, mas ficar com seu corpo - "do que me deixar quebrar os ossos" - , ainda que este corpo já tenha se tornado "incógnito", que se encontre "baixo e infame", tal qual uma vil mercadoria.

Reflexo da mercadoria, a corporeidade melancólica opera a partir deste "valor de estranhamento" do qual nos fala Agamben. Este corpo melancólico opera em si uma dupla contradição: absorve em si mesmo a mercadoria para, simultaneamente, "negá-la de dentro", tal qual a operação poética de Baudelaire descrita anteriormente ${ }^{33}$. Como essa corporeidade melancólica, tributária da própria ruína moderna e traço de um corpo mercantilizado, poderia negar sua própria condição e assim também seu contexto histórico-social, posto que é forjada dentro deste mesmo contexto? Como este corpo melancólico poderia se destituir de uma determinada condição, ganhando em valor de estranhamento? Qual seria a nova economia aurática desta corporeidade melancólica, entendida como o rastro de fumaça de um corpo moderno? Parece preciso recuperar o "choque", como vimos a propósito de Baudelaire, em vista de estabelecer um embate dialético entre o corpo do artista e o

33 “(...) a melancolia baudelairiana só pode ser compreendida, como percebeu Benjamin, se não se perder de vista que a particular relação entre linguagem poética e vida social, manifesta no texto de Baudelaire, deve ser lida como um palimpsesto, e que uma tal leitura deve necessariamente ser feita a "contrapelo", violentamente, para revelar os momentos de fissura, descontinuidade, em que determinações sociais concretas se instalam nos fragmentos menos aparentes do estilo poético. Esse complexo jogo de inter-relações entre produção poética e vida social é, pois, uma das formas pelas quais a melancólica duplicidade baudelairiana reiteradamente se manifesta para marcar, definitivamente, a necessidade de assimilar a visão poética do passado e simultaneamente destruí-la, aliás, para assimilá-la justamente sob o signo de sua negação ou destruição.” (LAGES, 2007: 143). 
mundo onde vive, em uma atitude de resistência em relação às forças econômicas que forjam o sujeito moderno. ${ }^{34}$

Baudelaire, para quem o ato de criação nasce "do grito do artista antes de ser vencido" 35 , incorpora a modernidade, porém trava uma espécie de diálogo negativo com esta, evidenciando, a partir do choque deste corpo com a própria modernidade que incorpora, as contradições entre o artista e o mundo. Enquanto a cidade [Paris] muda, para o melancólico, contraditoriamente, nada em seu corpo se move:

Paris muda! Mas nada em minha melancolia

Mudou! Novos palácios, andaimes, lajedos,

Velhos subúrbios, tudo em mim é alegoria,

E essas lembranças pesam

mais do que rochedos. (BAUDELAIRE, 2002: 82)

O diálogo negativo entre o $e u$ do artista e a realidade que o envolve é base fundante deste corpo melancólico, aquele que ainda conseguiria ressentir o choque e as contradições entre sua subjetividade e o progresso da modernidade. É desse choque que parece emergir sua potência de resistência: a melancolia evidencia a inadequação do sujeito à sua época, ao mesmo tempo que atesta sua lucidez em relação à mesma. Esta contradição pode ser vista na afirmação da autora Julia

\footnotetext{
34 "Ser moderno é encontrar-se em um ambiente que promete aventura, poder, alegria, crescimento, autotransformação e transformação das coisas ao redor - mas ao mesmo tempo ameaça destruir tudo o que temos, tudo o que sabemos, tudo o que somos". (BERMAN, 2014: 24).

35 "Envolvido nesta estranha esgrima (...) O duelo [de morte] que todo artista se envolve e no qual antes de ser vencido solta um grito de terror. (...) as descrições reveladoras da cidade grande (...) procedem daqueles que atravessaram a cidade distraídos, perdidos em pensamentos ou preocupações. É a eles que faz juz a imagem da estranha esgrima; Baudelaire teve em mira o seu comportamento, que é tudo, menos o de observador". (BENJAMIN, 2000: 69).
} 
Kristeva (1987) ao dizer que "o artista consumido pela melancolia é ao mesmo tempo o mais implacável a combater a demissão simbólica que o envolve" (KRISTEVA, 1987: 18) (Tradução nossa). A partir da negação, Baudelaire teria conseguido integrar o choque à sua lírica em um mundo no qual a vivência do choque já se tornou norma: se de um lado o poeta deixava que o espetáculo da multidão agisse sobre ele, de outro, não permitia que este fascínio o afastasse "da sua terrível realidade social" (BENJAMIN, 2015: 61). O choque, para Walter Benjamin, estaria relacionado ao impacto que a realidade causaria sobre a subjetividade, tornando sua recepção incompatível com a experiência:

[...] Benjamin reúne reflexões oriundas de duas proveniências: uma reflexão sobre o desenvolvimento das forças produtivas e da técnica (em particular sua aceleração a serviço da organização capitalista da sociedade) e uma reflexão convergente sobre a memória traumática, sobre a experiência do choque (conceito-chave das análises benjaminianas da lírica de Baudelaire), portanto, sobre a impossibilidade, para a linguagem cotidiana e para a narração tradicional, de assimilar o choque, o trauma, diz Freud na mesma época, porque este, por definição, fere, separa, corta ao sujeito o acesso ao simbólico, em particular à linguagem. (GAGNEBIN, 2014: 51)

Benjamin relacionou a crise da experiência e da linguagem à nossa incapacidade de transformar uma experiência vivida em experiência autêntica, devido ao impacto do trauma sobre o corpo e da impossibilidade de assimilarmos o choque. Se à época do autor os corpos ainda ressentiam e não assimilavam o choque, o trauma que vivemos em nossa hipermodernidade parece ser a distorção perversa desta situação: estamos a tal ponto traumatizados que já absorvemos o choque, o assimilamos sem estranhamento, não ressentimos seu impacto sobre 
nossos corpos, tornamo-nos apáticos em relação àquilo que nos violenta. No primeiro momento de Anatomia da Melancolia - experiência I, embora o corpo passe por inúmeros impactos contra o assoalho, seu estado de presença é de apatia, como se absorvesse em sua própria fisicalidade a violência sob a qual está submetido.

Nossa capacidade de espanto e de choque face à realidade foi neutralizada, no entanto, esta aparente neutralidade gera uma nova qualidade traumática (abatimento, angústia, ansiedade, entre outros sintomas) de incompreensão e inadequação a esta violência emudecida. Um desses traços é a melancolia, contraditoriamente, sintoma e antídoto de resistência a esse mesmo trauma. Este corpo melancólico procura encontrar, em suas ações de limiar, uma dramaturgia que possa reconstruir o choque, trazendo à tona as contradições de sua época, evidenciando o trauma e, assim, talvez resistindo à apatia contemporânea.

Como desnaturalizar o choque, liberando o corpo de seu trauma hipermoderno, trazendo à tona seu caráter irruptivo, seu clarão que ilumina as trevas - seu espanto -, emergindo daí a potência de resistência inapreensível do corpo moderno arruinado, este corpo melancólico? Se no primeiro momento de Anatomia da Melancolia - experiência I, o corpo se coloca apático em relação ao choque, sofrendo a violência sem reagir à mesma - emudecido -, em seguida, o corpo passa a realizar suspensões e rupturas, "estranhando" esta mesma violência. Meu corpo, com esforço, coloca-se em um eixo vertical, resistindo aos impactos e violência anterior, e dispara um monólogo acompanhado de uma gestualidade hipertônica que se desenvolve e paralisa no ar, como pequenas explosões que trazem à tona os traumas decorrentes dos choques vividos. 
Os choques que vivemos cotidianamente, e que tiveram seu ápice nas duas grandes guerras do século passado que, nas palavras de Benjamin, "traziam de volta soldados emudecidos e mais pobres de experiências partilháveis" (BENJAMIN, 2012: 86), são alegorizados na poesia de Baudelaire. Os choques estão cifrados em imagens alegóricas, tal é o caso da imagem do cisne do poema Le Cygne, de Flores do Mal:

Ali eu vi, certa manhã, à hora em que sob os céus

Frios e claros o Trabalho desperta, quando os varredores

Levantam uma sombria tormenta no ar silencioso,

Um cisne que fugira da gaiola,

E, raspando com as patas o pavimento seco,

Pelo chão áspero arrastava sua branca plumagem.

Perto de um córrego sem água o animal abrindo o bico

Banhava nervosamente suas asas na poeira,

E dizia, o coração tomado por seu belo lago natal:

“Água, quando cairás como chuva? Quando ressoarás, trovão?"

Eu vejo esse infeliz, mito estranho e fatal,

Por vezes para o céu, como homem de Ovídio,

Para o céu irônico e cruelmente azul.

Voltar a cabeça ávida para o pescoço convulsivo,

Como se dirigisse censuras a Deus! (BAUDELAIRE, 1997: 134)

Jean Starobinski, em seu livro A Melancolia diante do espelho, no qual analisa, entre outros, este mesmo poema, diz-nos que "Entre os 
filhos de Saturno ${ }^{36}$, voltados à melancolia, os prisioneiros figuravam em posição de destaque. O cisne na gaiola é um soberbo emblema da melancolia" (STAROBINSKI, 2014: 63). O poeta faz emergir a melancolia a partir da oposição entre alegorias contrárias, entre treva e luz: "céus frios e claros, entre certa manhã, sombria tormenta e branca plumagem.".

O crítico literário Dolf Oehler, quando estuda autores da modernidade, afirma que estas obras não podem ser entendidas sem se levar em conta a experiência das jornadas de 1848: "as jornadas de junho de 1848 não representam apenas uma das datas mais dolorosas da história do século XIX, que dividiu a nação francesa em dois campos, e cuja repressão - ao contrário da história análoga da Comuna - nunca foi realmente superada (...). A isso se soma que o substrato histórico dos textos canônicos (Heine, Baudelaire, Flaubert) foi tanto cifrado pelos próprios autores quanto soterrado pela história de sua recepção." (OEHLER, 1999: 22).

O movimento proposto em Baudelaire é de resistência à sua época sem, todavia, anulá-la, ao contrário, sendo contaminado por ela ("Trabalho, varredores, pavimento": índices da modernidade), evidenciando as contradições de seu momento histórico na forma mesma de sua linguagem, criando alegorias que só podem ser decifradas se as

\footnotetext{
36 “(...) Saturno, que, 'como planeta supremo, o mais afastado da vida quotidiana, é responsável por aquela funda contemplação que leva a alma a desviar a atenção das coisas exteriores para o interior (...)'. Tal como a melancolia, também Saturno, esse demônio dos contrastes, investe a alma, por um lado com a indolência e a apatia, por outro com a força da inteligência e da contemplação (...) devido às suas qualidades de astro pesado, frio e seco, gera homens completamente presos à vida material, só adaptados ao duro trabalho do campo, mas devido à sua localização, como o mais alto dos planetas, produz, pelo contrário, os religiosi contemplativi, homens extremamente espiritualizados e indiferentes à vida terrena.” (BENJAMIN, 2013: 155-157).
} 
relacionarmos, dialeticamente, com o mundo da mercadoria. Descreve Baudelaire em $O$ pintor da vida moderna:

Se lançarmos um olhar a nossas exposições de quadros modernos, ficaremos espantados com a tendência geral dos artistas para vestirem todas as personagens com indumentária antiga. Quase todas se servem das modas e dos móveis do Renascimento (...). Evidentemente, é sinal de grande preguiça; pois é muito mais cômodo declarar que tudo é absolutamente feio no vestuário de uma época do que se forçar por extrair dele a beleza misteriosa que possa conter, por mínima ou tênue que seja. A Modernidade é o transitório, é a metade da arte, sendo a outra metade o eterno e o imutável. (BAUDELAIRE, 1996: 24-25)

Essa absorção e negação da modernidade em Baudelaire poderia ser vista como a própria efetivação do conceito de escovar a história a contrapelo de Benjamin. Segundo esse autor:

Não há documento de cultura que não seja também documento de barbárie. E, do mesmo modo que ele não pode libertar-se da barbárie, assim também não o pode o processo histórico em que ele transitou de um para o outro. Por isso o materialista histórico se afasta quanto pode desse processo de transmissão da tradição, atribuindo-se a missão de escovar a história a contrapelo. (BENJAMIN, 2013: 13)

Escrevendo na negativa do progresso do século XIX e "escovando a modernidade a contrapelo", a arte moderna para Baudelaire deveria denunciar em sua época o seu valor de troca, revelando assim, contraditoriamente, sua própria autenticidade. Longe de criar uma linguagem cuja forma estivesse dissociada de seu conteúdo e questões históricas (como o que se via nos Salons e nas Exposições universais na 
Paris do século XIX, alvo de crítica em $O$ Pintor da vida moderna ${ }^{37}$ ), o processo de criação do artista dar-se-ia em combate negativo, "a contrapelo" das relações de trabalho forjadas no capitalismo, em conflito dialético entre sujeito e mercadoria. A obra substituiria assim a própria realidade ideológica da mercadoria, apropriando-se dela para negá-la, conferindo-lhe outro sentido. Em Anatomia da melancolia - experiência I, esta relação entre absorção e negação pode ser vista se justapusermos o primeiro momento - de apatia - do solo, ao segundo momento - de negação e resistência - a essa mesma apatia, tal como descrito anteriormente.

Pode-se entender o corpo melancólico como um corpo da contradição, posto que opera no choque entre a mercadoria e sua própria negação. É a partir da própria imagem da mercadoria e da esgrima entre sujeito e realidade, que o corpo poderia, talvez, libertar-se de seu estatuto fetichizante e de seu caráter utilitário. Esse corpo, simultaneamente, apreende a mercadoria em si mesmo - torna-se, ele mesmo (seus próprios "ossos", como no poema de Baudelaire) uma mercadoria - para negá-la em seguida. Sua corporeidade é caracterizada, assim, por uma contradição dialética, cujos fluxos energéticos contraditórios se chocam entre si, forjando um corpo em limiar entre a absorção e a negação da mercadoria.

Um dos procedimentos encontrados, em Anatomia da melancolia experiência $I$, para trazer à tona o choque normatizado, foi o de fazer o corpo operar a partir de enunciados contraditórios: se de um lado este corpo melancólico se encontra em total paralisia, petrificado, tragado pela gravidade da Terra e pelas leis terrenas do capital (primeiro

\footnotetext{
${ }^{37}$ BAUDELAIRE, Charles. O Pintor da Vida Moderna. Belo Horizonte: Autêntica, 2010.
} 
momento do solo), de outro é justamente a partir da insistência sobre essa imobilidade, do trabalho sobre essa impiedosa anulação subjetiva, que pode emergir uma ação de resistência melancólica; o corpo "hiperboliza" essa imobilidade, indo ao seu grau máximo e extremo. A partir de uma hipertonificação muscular (segundo momento do solo), o corpo resiste à gravidade que ressente, até que, desta hiperbólica paralisia, emerja um corpo estranho-familiar, sua revolta, seu contrário: um furor desenfreado que caracteriza o terceiro momento de Anatomia da melancolia experiência I.

Julia Kristeva, em seu livro Soleil Noir, dépression et mélancolie, problematiza a melancolia a partir do ponto de vista desta fisicalidade. A dinâmica melancólica implica em uma corporeidade tanto individual quanto coletiva em nossa sociedade; segundo a autora:

$\mathrm{Na}$ tensão dos afetos, dos seus músculos, das suas mucosas e da sua pele, ele prova ao mesmo tempo seu pertencimento e sua distância, frente a frente de um outro arcaico que escapa da representação e da nominação, mas cujas descargas corporais e seu automatismo guardam as marcas. (KRISTEVA, 1987: 24) (Tradução nossa)

A partir da reflexão da autora, chego a um dos enunciados experimentados neste corpo melancólico, o qual chamei de autodestruição: seguindo o princípio da contradição, o corpo parte de um estado de inquietação petrificada, segundo o qual ele experimenta sua "distância” em relação à própria vida (tornando-se imóvel). Indo ao extremo de suas tensões musculares que guardam os afetos desse corpo, uma descarga, um furor, irrompe de sua aparente inércia, anunciando seu "pertencimento" a essa mesma vida que foi negada: 
O artista que se consuma de melancolia é ao mesmo tempo o mais implacável a combater a demissão simbólica que o envolve... Até que a morte o atinja ou que o suicídio se imponha para alguns como triunfo final sobre o nada do objeto perdido. (Ibidem: 18) (Tradução nossa) ${ }^{38}$

Ao repetir (lembrar) o choque entre contrários (paralisia-furor), o trauma é libertado e traduzido em linguagem (inquietação) deste corpo, chegando assim a uma espécie de reconciliação não harmônica com a própria potência perdida.

\section{MELANCOLIA E $O$ ESTRANHO 39}

Os séculos XIX e XX foram marcados pela absorção da capacidade humana de espanto, da capacidade social de estranhamento, reflexão e crítica. A economia capitalista, seguida de sua ideologia liberal, tratou de normatizar nossa tragédia: o normal e o anormal, o doente e o saudável, entre outras classificações dicotômicas, como bem nos fala o filósofo Michel Foucault (1926-1984) em diversas de suas reflexões:

O indivíduo "anormal" que, desde o fim do século XIX, tantas instituições, discursos e saberes levam em conta, deriva (...) da construção de uma teoria geral da "degeneração" que vai, por mais de meio século, servir de marco teórico, ao mesmo tempo que de justificação social e moral, a todas as técnicas de

\footnotetext{
38 No original: "L'artiste qui se consume de mélancolie est en même temps le plus acharné à combattre la démission symbolique qui l'enrobe... Jusqu'à ce que la mort le frappe ou que le suicide s'impose pour certains comme triomphe final sur le néant de l'objet perdu.".

${ }^{39}$ Vale aqui uma passagem de G. K. Chesterton (1968: 231), um dos romancistas preferidos de Benjamin: "Em sua mente pareceu abrir-se uma janela, deixando penetrar essa estranha luz de surpresa que permite dar-nos conta do que sempre temos visto." .
} 
detecção, classificação e intervenção concernentes aos anormais; a criação de uma rede institucional complexa que, nos confins entre a medicina e a justiça, serve ao mesmo tempo de estrutura de "recepção" para os anormais e de instrumento para a "defesa" da sociedade. (FOUCAULT, 2001: 418)

É preciso que nada saia desta ordem, para que se possa prever a vida, os erros e então dominá-los, para que o ser humano não estranhe a violência constante, para que não experimente outras possibilidades de organização social. Qualquer posicionamento diante da história do mundo são perversamente apaziguados, sendo então administrados. Não há espaço para revolta, já que a história não mais pertence a este indivíduo cuja própria capacidade de estranhamento foi expropriada. Contrário a esta lógica dicotômica, as ações melancólicas se fazem a partir de uma dialética da suspensão, ideia sobre a qual falaremos mas adiante.

Reduzindo a melancolia a um mero sintoma, normatiza-se este sentimento, assimilando-o como uma anomalia patológica, anulando-se sua potência de contestação. Patologizar e afirmar uma identidade entre melancolia e depressão é retirar do corpo melancólico sua potência de resistência e de negação ao projeto ideológico de dominação do corpo. $\mathrm{Na}$ sociedade hipermoderna, regida unicamente pela ideologia do mercado, não há interesse sobre a visão crítica que a melancolia poderia sugerir ao corpo social, posto que isso geraria uma desordem política desse mesmo corpo: o do indivíduo e o do coletivo. Assim, o corpo melancólico deve aqui ser claramente diferenciado do corpo depressivo, por uma questão conceitual, estética, artística, econômica, política: o melancólico implica em um corpo do limiar, em fluxo de contradições dialéticas, não resignado (tampouco medicalizado), não apaziguado pela 
razão administrada, um corpo que ainda guarda (por mais que esteja soterrada) uma "substância simbólica" que escapa às classificações normativas. Slavoj Zizek (2009) nos ajuda a entender esta problematização:

$\mathrm{O}$ que nos une é que, em contraste com a imagem clássica do proletariado que "não tem nada a perder a não ser os grilhões", corrermos o risco de perder tudo: a ameaça é que sejamos reduzidos a sujeitos abstratos vazios de todo conteúdo substancial, despossuídos de nossa substância simbólica, nossa base genética fortemente manipulada, vegetando num ambiente inóspito. Essa tripla ameaça ao nosso ser inteiro transforma todos nós em proletários, reduzidos à "subjetividade sem substância", como explicou Marx nos Grundrisse. O desafio ético-político é nos reconhecermos nesta imagem; de certo modo somos todos excluídos, tanto da natureza quanto de nossa substância simbólica. Hoje, somos todos potencialmente homo sacer, e a única maneira de impedir que isto se torne realidade é agir de modo preventivo. (ZIZEK, 2009: 84)

Embora a modernidade esteja de certo modo anunciada desde a Renascença, em recusa "das trevas" medievais e eclesiásticas, é com o progresso das cidades e do capital, no século XIX, que sua ideologia se instaura. $\mathrm{O}$ sujeito passa a estar claramente subjugado à finalidade do capital - este "novo Deus" - e à história dos "vencedores", a partir da qual a linguagem e arte que poderiam traduzir e refletir nossas contradições históricas teriam sido mercantilizadas, pois até mesmo o corpo se torna capital, sem capacidade de estranhamento, à despeito do empreendimento crítico de poetas como Shakespeare ${ }^{40}$, Goethe e

\footnotetext{
${ }^{40}$ Em Origem do Drama trágico Alemão (2013b), Benjamin, a propósito da acédia e da infidelidade do melancólico, tomando como exemplo a obra Hamlet de Shakespeare, nos diz que "a melancolia trai o mundo para servir o saber" (BENJAMIN, 2013: 164) o
} 
Baudelaire. O corpo da modernidade confunde-se assim com a própria mercadoria: perde sua capacidade de contradição. O corpo melancólico, na negativa desse modus operandis, seria aquele que, embora resultante desse mesmo processo, não se resigna, não se confunde completamente, embora se contamine, em sua própria fisicalidade, tensões e fluxos energéticos, pelas forças econômico-sociais que o produzem. A melancolia opera como um afeto sintomático de resistência ou "medida preventiva", como diz Zizek, diante da necessidade de resistir à história arruinada, em um mundo marcado pelo fetiche do capital:

Benjamin (...) pretende tematizar (...) a aura, a experiência autêntica e a experiência do choque. Todas elas emergem de uma profunda melancolia e do tédio - que não é senão a constatação de uma indigência que tanto marcou a experiência do homem do século XIX. (CANTINHO, 2015: 8).

A falta do sentimento de satisfação, esse tédio acidioso que caracteriza a corporeidade melancólica, viria justamente da separação moderna entre sujeito privado e sujeito histórico, criando uma cisão subjetiva que constitui o homem burguês na modernidade, cindido entre

que justificaria o humor, a atitude e as palavras do personagem: Hamlet "trai" a ordem política de seu reino em vista da verdade da história, em vista de averiguar o que "verdadeiramente" ocorreu, revelando as falácias e miséria das relações humanas que regem seu Estado. Esta traição pode ser vista ao mesmo tempo como uma negação uma "ação a contrapelo" - da ordem externa e um "olhar transfigurado de reflexão sobre si próprio" (tendo como emblema máximo da obra o célebre "ser ou não ser, eis a questão"). Ao estranhar o próprio contexto político, Hamlet engendra um estranhamento de si mesmo diante de sua época; seu "ser ou não ser" refere-se, assim, tanto ao contexto político do Estado, quanto a seu contexto existencial. Hamlet seria um melancólico que se percebe como um "estranho" diante de seu tempo atual, diante da "ordem" que reina na Dinamarca. Na dinâmica do melancólico, Hamlet opera em uma dupla negação: estranha o mundo e estranha a si próprio diante de sua história e contexto político e social. 
a eternidade infinitamente vazia da ideologia do capital e sua mortalidade, assim como entre seu pensar e fazer histórico (esquecidos tal como o objeto traumático recalcado no inconsciente). Debruçarmonos sobre uma corporeidade melancólica consiste, em síntese, em considerar corpos que, embora submetidos aos imperativos do mercado e transformados em verdadeiras máquinas desejantes, são incapazes de satisfazer seus desejos, colocando-se em situação de inadequação e estranhamento em relação à norma estabelecida: sua tristeza e tédio decorrem da impossibilidade de reencontro com seu "objeto perdido", capaz de reconciliar o eu e o mundo.

Este corpo melancólico parece ser um dos sintomas desta cisão criada desde a modernidade: o sentimento de esvaziamento advém da falta de conexão entre o "eu" individual e o "eu" social, coletivo. Paradoxalmente, a consciência de seu vazio concebe esse corpo como um corpo em limiar, ou seja, um corpo que não é nem "um" nem "todos", nem indivíduo, nem político, mas que constela, em sua própria "ausência", todas essas potências que operam liminarmente em uma corporeidade melancólica.

Um processo sócio-metabólico, como diria o sociológo Istvan Mèszaros ${ }^{41}$, baseado apenas na reprodução do capital, enfatiza a primazia do indivíduo em detrimento do coletivo, afirma de maneira totalitária a fronteira entre público e privado, entre indivíduo e sociedade. $\mathrm{O}$ liberalismo baseia-se em um ideal de vida do indivíduo: o sucesso

\footnotetext{
41 Por sócio-metabolismo do capital podemos entender uma estrutura totalizante de organização e controle, cujos elementos constitutivos - capital, trabalho (assalariado) e Estado - associam-se em um único sistema de controle do metabolismo social. Ao romper com a compartimentação e a restrição internas definidas pelos sistemas de controle precedentes, a evolução histórica do capital determinou uma mudança radical sobre o corpo da sociedade, que culminou gradualmente na consumação da reprodução desenfreada do capital, mundial e totalitário, plenamente desenvolvido no presente sistema-mundo.
} 
individual é uma meta e valor social que, paradoxalmente, gera uma grande carga de frustração, pois constitui-se a partir do alheamento do "eu" em relação às questões coletivas, fundamentando uma sociedade fracionada e cindida, da qual originam-se as inumeráveis patologias mentais hoje perfiladas. É diante desse totalitarismo que surge a inadequação e incompreensão do melancólico, fazendo emergir em seu próprio corpo o sintoma desta cisão forjada no seio do desenvolvimento capitalista dos últimos três séculos.

Diferentemente do corpo enlutado, cujo objeto perdido se encontra fora dele mesmo, o corpo melancólico guarda em si mesmo seu objeto ausente: o que lhe falta não é algo "externo" que foi perdido (como no caso do luto), mas é o "si mesmo", sua própria subjetividade cindida de sua autenticidade histórica, de seu corpo comum, partilhado. Este "ausente" seria o próprio sujeito de recalque, aquele que participa da constituição subjetiva do $e u$, diferentemente do objeto concreto que foi perdido no luto: pessoa amada, parente etc. Sobre essa diferenciação:

Segundo Freud, a distinção entre "trabalho de luto" [Trauerarbeit] e "melancolia" remete a um sentimento anterior à perda concreta, o sentimento do eu (Ichgefühl). Na compleição melancólica, esse sentimento é o de desvalorização, de empobrecimento, de esvaziamento: enquanto no luto é o mundo que se torna vazio devido à ausência da pessoa amada, na melancolia é o próprio eu que se esvazia, que não tem mais a força de se recompor, de viver novamente. (GAGNEBIN, 2009: 105)

O luto que o corpo melancólico não consegue fazer revela um desfalecimento de sua experiência subjetiva social, deformada por nossa própria constituição social, segundo a qual o corpo político - e nossa 
subjetividade histórica - tornou-se, ele mesmo, mercadoria ${ }^{42}$. Na peça Anatomia da melancolia - experiência I, busquei colocar em prática a relação entre este desfalecimento do corpo e sua condição de mercadoria, procurando revelar tanto o sintoma - seu vazio e abatimento - quanto às causas desta paralisia traumática. O corpo, em sua condição de "objeto", passa por inúmeros choques que o ejetam violentamente de um lado para outro (sempre no plano baixo). O corpo, neste momento passivo, sem forças, ainda impotente em relação à exploração sofrida, deixa-se ser arremessado, pois já tornado mercadoria (na qual a subjetividade é ausente).

Entendemos aqui, portanto, que o objeto perdido para o melancólico pode ser visto como sua própria subjetividade. O sentimento do eu está emudecido pelo progresso das cidades, da cultura, da civilização. Daí o nosso interesse em Baudelaire, acerca do que sua obra possui de inacabamento, do que deflagra enquanto perda, esburacamento, trazendo à tona a experiência reprimida do sujeito histórico. É a partir deste trauma, do deserto de corpos exterminados, de "homens reduzidos a objetos e mortos a partir de listas; perseguição e tortura; os muitos tipos de martírio contemporâneo" (WILLIAMS, 2002: 90), que podemos vislumbrar o negativo da história dos vencedores, reconhecendo o instante em que se pode escutar os sussurros deste passado ainda presente.

\footnotetext{
${ }^{42}$ Como alegoria de nossa história brasileira e de sua demissão subjetiva - cuja desordem radical está mascarada - valeria olhar para a figura da prostituta sobre a qual nos fala Benjamin em seu Passagens. Partindo da poesia de Baudelaire, para Benjamin, a prostituta é ao mesmo tempo sujeito e objeto, relacionando-a à própria modernidade: "A mercadoria considerada em termos absolutos, ou seja, como fetiche (...), assim como as passagens são ao mesmo tempo rua e casa, e que a prostituta, que é em uma só pessoa vendedora e mercadoria." (BENJAMIN, 1989: 43) (tradução nossa).
} 
Se por um lado o trauma - sintoma da repressão dos sussurros inconscientes e coletivos - paralisa o corpo melancólico, por outro:

(...) faria retornar tudo aquilo que precisou ser deixado, ou alienado (...) faria retornar um corpo desejante não mais individual, mas social. O estranho - personagem que nos provoca uma inquietante perturbação e, de algum modo, nos faz sentir, ao menos uma ou outra vez, sem que saibamos dizer bem por quê, certo mal-estar de vivermos em civilização. (SOUZA e GALLO, 2002: 55)

Poderíamos dizer que este corpo melancólico contém seu corpo unheimlich ${ }^{43}$, guardando em si um sujeito estranho-familiar em latência (pois encoberto pelo trauma), seu próprio duplo estranho que "precisou ser deixado, ou alienado". Estranho porque é desconhecido (está esquecido, encoberto, soterrado) e familiar, pois é ele mesmo seu objeto/sujeito da falta: tal como a mudez que supõe a palavra (calada), o unheimlich (estranho) supõe o heimlich (conhecido, familiar). Ora, o que é familiar ao corpo moderno, mas que está faltante, é sua própria capacidade de estranhamento, recalcada pelo trauma. É daí que se pode pensar a potência de resistência do melancólico, potência que reside em sua própria fisicalidade - em suas tensões e afetos -, na contradição constitutiva de sua corporeidade: essa ecoa a experiência traumatizada do corpo social da modernidade, contém em seu próprio assujeitamento sua potência subjetiva de resistência sufocada, antídoto à sua condição.

\footnotetext{
43 "O estranho é, antes de tudo, algo que se tornou unheimlich por ter sido antes familiar (heimlich) - a imagem no espelho que não é reconhecida como sendo eu mesmo, por exemplo. Se a teoria psicanalítica estiver correta, unheimlich é efeito de um material que retorna, um desejo que há muito foi interditado por repressão". (SOUZA e GALLO, 2002: 57)
} 
Por mais que se tente patologizar e categorizar esse estranho malestar, segundo Freud, por princípio lógico, o estranho jamais é assimilável:

O estranho tem a ver, fundamentalmente, com o desconhecido que somos nós para nós mesmos. O estranho tem uma territorialidade que escapa à localização; sua presença está fadada a ser apenas sentida, dado que não se submete à racionalidade de nenhum tipo. Sua ordem é a do desejo, portanto, seu espaço, paradoxalmente é o da falta. Sua presença entre/em nós convoca-nos ou para a vida com seus jorros, ou para a morte - morte desse estranho em nós, tão insistente em ser saciado, tão aparentemente desinteressado em nos fazer voltar à unidade especular. (Ibidem: 57)

Vivemos em uma sociedade na qual o trauma deve ser apagado (e não vivido) e o melancólico - enquanto símbolo de inadequação ao fluxo da hipermodernidade - deve ser, portanto, medicalizado, ou seja, seu sentimento e afetos devem ser igualmente "apagados". Entretanto, essa é uma tarefa impossível (pressupõe a luta contra a própria história e mortalidade do ser humano) dado que, segundo Freud, o que foi esquecido e oprimido é a "base fundante do sujeito", não tendo como desaparecer. O sujeito existe justamente no que foi apagado e esquecido, nas palavras de Julia Kristeva, "na sombra que recai sobre o melancólico":

"A sombra do objeto caiu sobre o melancólico", diagnostica Freud (...). Ela o condena a se debruçar sobre si mesmo, permanente vigilante da noite, inspetor inconsolável. (...) mesmo que "o êxtase não visite jamais seu coração" (...) Baudelaire é uma "alma hiperbólica" que "levita" em direção "à 
bondade daquele que tudo nomeia" (...). (KRISTEVA, 1990: 44-45) (Tradução nossa) 44

É nesta sombra, nesta espécie de ausência que supõe uma presença matriz, que parece residir a força messiânica da verdade para Walter Benjamin. Essa sombra nos indica que há algo para além do que conseguimos ver ou escutar - segundo nossa visão e escuta ordinárias (a saber, segundo os sentidos despotencializados que usamos em nosso cotidiano normativo, no qual o trauma está inaudível e só pode ser percebido como sussurro ou breve feixe de luz, clarão ou relâmpago ${ }^{45}$ ) , se formos capazes de recolocar as forças em choque novamente. Se Freud nos diz que o trauma é base fundante do sujeito, não tendo como desaparecer, do mesmo modo os sussurros (ainda que emudecidos pelo progresso), o que foi reprimido (e oprimido), ainda está ali, mesmo que possamos ver apenas sua sombra, ou ainda, escutar seus ecos distantes. Essa sombra figura como índice de que as palavras reprimidas dos vencidos permanecem materialmente presentes, mesmo que em latência. Ainda que aparentemente emudecido e apaziguado (pelas diferentes estratégias contemporâneas de "medicalização" que não só as medicamentosas, mas também pelo consumo), este estranho "eu"/objeto perdido subjaz no inconsciente de uma história coletiva e social massacrada, história que também compõem esta corporeidade melancólica:

\footnotetext{
${ }^{44}$ No original: "L'ombre de l'objet est tombée sur le mélancolique", diagnostique Freud (...). Elle le condamne à se pencher sur lui- même, permanent veilleur de nuit, inspecteur inconsolable. (...) mesmo se "o êxtase não visita nunca sei coração" (...) Baudelaire est une "âme hyperbolique" toute en "lévitation" vers "la bonté de celui que tout nome." (KRISTEVA, 1990: 44-45).

${ }^{45}$ Benjamin se vale de todos esses nomes em suas diversas passagens.
} 
O objeto não é algo que realmente morreu [como no caso do luto], mas que se perdeu como objeto de amor (...). não podemos discernir com clareza o que se perdeu e com razão podemos supor que o doente também não é capaz de compreender conscientemente o que ele perdeu. Poderia ser também este o caso de quando o doente conhece qual é a perda que ocasionou a melancolia, na medida em que de fato sabe quem ele perdeu, mas não o que ele perdeu nele (no objeto). Isso nos levaria a relacionar a melancolia com uma perda de objeto que foi retirada da consciência, à diferença do luto, no qual nada do que diz respeito à perda é inconsciente. (FREUD, 2013: 51)

$\mathrm{O}$ vazio do indivíduo moderno testemunha esta perda inconsciente. A falta de ânimo e desejo do melancólico advém de um cotidiano que se repete como um presente contínuo, sem desvio e sem memória, um corpo quase "amorfo", que vive em um eterno e triste presente dos dias que se sequenciam em violenta e perversa harmonia. Essa qualidade de uma corporeidade "amorfa" também constituiu um dispositivo na criação de Anatomia da Melancolia - experiência I: enquanto experimenta ir ao extremo hipertônico de seus músculos, o corpo se deforma a todo tempo, instaurando torções hiperbólicas entre a parte superior e inferior do corpo, utilizando apoios frágeis (apoia-se inteiramente apenas sobre uma crista ilíaca, por exemplo), conferindo a esse corpo uma "deformação" fora de um eixo previsível -, uma forma danificada.

O melancólico não seria apenas aquele que não satisfaz seus desejos individuais (objetivo impossível de ser alcançado e, no entanto, freneticamente imposto ao homem hipermoderno), mas ainda, aquele que está privado de escutar uma certa satisfação coletiva relacionada à ideia 
de liberdade que foi dizimada em sua época ${ }^{46}$. O estado melancólico e as linhas de força que este estado opera no corpo manifestam a "falta" deste indivíduo que se vê distante, despossuído de sua própria história que jaz soterrada, mas não sepultada (!). Poderíamos dizer que este corpo melancólico figura como um cadáver insepulto da modernidade.

Se, como dissemos acima, o sujeito moderno foi sendo individualizado e privado de seu exercício público; se seus interesses individuais parecem não se relacionar com seu exercício coletivo, fazendo com que este se encontre cindido entre um eu individual e um eu social; também nos falta uma experiência de linguagem em que a cisão entre sujeito e objeto possa ser problematizada. Quem seria o outro, espelho estranho do eu melancólico contemporâneo? Esta falta, esse outro, integrante complementar e negativo deste corpo melancólico, não seria o eu coletivo, estranhamente familiar?

O neurótico, em psicanálise, é aquele que se esforça para submeter-se às exigências do supereu, como se com isso lhe fosse possível reverter a perda subjetiva (...) e recuperar a unidade (impossível) com o Outro [unidade que Lacan resumiu em diversos seminários sob a fórmula $\mathrm{I}=1+\mathrm{a}$. O UM, como totalidade, seria a soma da singularidade com o objeto perdido, se esse (re)encontro fosse possível. Como o Outro é uma função simbólica transubjetiva, voltamos neste ponto à proposição lacaniana de que o inconsciente é político. (KEHL, 2009: 47).

\footnotetext{
${ }^{46}$ Para Saint-Just (1767-1794), por exemplo, contrariamente à ideologia do progresso, a felicidade não se traduz por uma harmonia sem conflito, ela está justamente na luta, na derrubada do soberano, no combate entre fios tensionados. Esta ideia de felicidade baseia-se na não disjunção entre personagem privado e personagem público (ideia cara à Revolução Francesa).
} 
Poderíamos dizer que este objeto de falta é seu próprio corpo comum, social, este estranho parente: este outro que é ele mesmo em sua obliterada experiência e corporeidade histórica ${ }^{47}$. Uma corporeidade melancólica, que nasce do trauma entre este "eu" e seu estranho reflexo histórico, opera no limiar do indivíduo e do coletivo, constituindo uma linguagem que - para que se torne gesto, movimento, ação e deslocamento - precisa, necessariamente, deixar emergir o choque que até então esteve emudecido e paralisado em seu corpo.

\section{CORPOREIDADE DO CHOQUE}

Ao refletir sobre este corpo melancólico, como tentei demonstrar até o momento, suponho um corpo que é simultaneamente sujeito e objeto $^{48}$, que é resultado da constelação de poderes sociais, econômicos e políticos, mas que, contraditoriamente, também resiste aos mesmos. Uma corporeidade que pode ser vista como um traço manifesto de nosso trauma coletivo e social; corpo em falta de sua subjetividade coletiva e histórica, composto, em sua fisicalidade mesma, por forças contraditórias, advindas de seu contexto. A relação entre essa corporeidade melancólica e os choques e traumas que a originam parece ficar clara a partir desta passagem de Julia Kristeva (1987):

\footnotetext{
47 “Ser moderno é viver uma vida de paradoxo e contradição. É sentir-se fortalecido pelas imensas organizações burocráticas que detêm $\mathrm{o}$ poder de controlar $\mathrm{e}$ frequentemente destruir comunidades, valores, vidas; e ainda sentir-se compelido a enfrentar essas forças, a lutar para mudar o seu mundo transformando-o em nosso mundo." (BERMAN, 2014: 21-22).

48 “Trata-se em outros termos, de chamar a atenção para a práxis histórica, cujo < sujeito > são as forças políticas, trata-se de dirigir a atenção às forças transformadoras e não apenas ter em conta as determinações sócioeconômicas que não levam senão a < objetos >". (MARTINS, 2014: 10).
} 
A tristeza (como todo afeto) é a representação física de deslocamentos energéticos provocados por traumas externos ou internos (...). Digamos que as representações próprias aos afetos, e notadamente, a tristeza, são investimentos energéticos "flutuantes": insuficientemente estabilizados para coagular em signos verbais ou outros, agidos por processos primários de deslocamento e condensação (...). Os humores são também inscrições, rupturas energéticas e não apenas energias brutas. (KRISTEVA, 1987: 3132) (Tradução nossa) ${ }^{49}$

É interessante notar que quando falamos dessa corporeidade melancólica, falamos de uma qualidade de linguagem que não apenas reflete o trauma, mas que é composta ela mesma de traumas, um corpo que é em si uma constelação de forças e linhas energéticas que o atravessam, tal qual sua corrente sanguínea. Nosso ponto de vista, portanto, não supõe esse corpo como "metáfora" de seu contexto, mas sim ele mesmo, igualmente, um contexto formado por tensões e conflitos energéticos, por investimentos energéticos flutuantes.

Quem viu as duas torres gêmeas de Nova York vindo abaixo pela televisão, no dia 11 de setembro de 2001, converteu-se em mutilado de guerra. Mutilado no olhar. Considerando que quase todos ou mesmo todos viram a cena da queda das torres, é forçoso concluir que quase todos ou mesmo todos acabaram por se tornar mutilados de guerra. (...) No lugar das duas torres, irrompeu o vazio. $\mathrm{O}$ ato terrorista de $11 \mathrm{de}$ setembro descosturou a paisagem e, mais ainda, abriu um rasgo na linguagem, esgarçou a ideologia,

\footnotetext{
${ }^{49}$ No original: "La tristesse (comme tout affect) est la représentation psychique de déplacements énergétiques provoqués par des traumatismes externes ou internes (...) pré-signe et pré-langage. L'humeur "tristesse" déclenchée par une excitation, tension ou conflit énergétique dans un organisme (...). Disons que les représentations propres aux affects, et notamment la tristesse, sont des investissements énérgetiques fluctuants: insuffisamment stabilisés pour coaguler en signes verbaux ou autres, agis par des processus primaires de déplacement et condensation [...]. Aussi les humeurs sont-elles des inscriptions, des ruptures énergétiques et non seulement des énergies brutes.".
} 
deixando ver o lado escuro do avesso do cenário. $\mathrm{O}$ ato terrorista interferiu na instância do olhar, que conecta a sociedade consigo mesma, e, assim, conseguiu o inacreditável: feriu o corpo de cada um, tanto daqueles a quem pôde matar sob os escombros dos edifícios como daqueles a quem, na forma de um show, alcançou como imagem. (BUCCI, 2009: 84)

Recorrendo a uma experiência traumática que representa com precisão, nossa hipermodernidade, a do 11 de setembro, Eugenio Bucci nos recorda sobre uma sociedade em que os mutilados de guerra, ao contrário da época de Benjamin, são mutilados pelas imagens, espetacularizadas e transformadas em mercadoria. Embora este corpo melancólico tenha sido privado, por meio do trauma, de seu acesso ao simbólico, contraditoriamente, os fluxos energéticos (deslocamentos e condensações) provocados por essa cisão e o "refinamento" de sua tristeza podem se traduzir em potência combativa e criadora: nesse processo, a tristeza de origem se torna processo de criação e ação de resistência, retomando Kristeva (1987):

Eles [os humores] nos conduzem a uma modalidade do significado que, no limiar dos equilíbrios bioenergéticos, garante as pré-condições (ou manifestam as dissoluções) do imaginário e do simbólico. Nas fronteiras da animalidade e da simbolização, os humores, - e a tristeza em particular - são as reações últimas aos nossos traumas, nossos recursos homeostásicos de base. Pois, se é verdade que uma pessoa escrava de seus humores, um ser afundado em tristeza, revela certas fragilidades psíquicas e na construção de suas ideias, é igualmente verdade que uma diversificação dos humores, uma gama de tristeza, um refinamento da mágoa ou do luto, são a marca de uma humanidade certamente não 
triunfante, mas sutil, combativa e criadora... (KRISTEVA, 1987: 31-32) (Tradução nossa) ${ }^{50}$

A melancolia opera, assim, como uma potência irruptiva deste corpo contemporâneo normatizado. Nossa corporeidade melancólica tem como princípio motriz de sua fisicalidade uma dinâmica de negação e resistência, conjugando em si uma contradição: de um lado ela é a linguagem sintomática do emudecimento (resultado de inúmeros massacres subjetivos de nossa época, do soterramento dos ideais revolucionários de liberdade, entre outros...), caracterizando um corpo dilacerado, cujo sentimento maior pode ser visto como uma plenitude do vazio, de outro lado, trata-se de uma linguagem de resistência, exatamente por estar preenchida de latência traumática, como um deserto frio que traz em seus ventos pequenos cristais de fogo e sementes de utopia. Para Benjamin (2012), esse cristal forjado a partir de choques dialéticos constituiria uma paragem messiânica do acontecer, ou ainda, uma oportunidade revolucionária:

Do pensar faz parte não apenas o movimento dos pensamentos, mas também sua paragem. Quando o pensar se suspende subitamente, numa constelação carregada de tensões, provoca nela um choque através do qual ela cristaliza e se transforma numa mônada. Nessa estrutura, ele reconhece o sinal de uma paragem messiânica do acontecer ou, por outras palavras, o

\footnotetext{
${ }^{50}$ No original: "Elles nous conduisent dans une modalité de la signifiance qui, au seuil des équilibres bioénergétiques, assure les pré-conditions (ou manifeste les dissolutions) de l'imaginaire et du symbolique. Aux frontières de l'animalité et de la symbolicité, les humeurs - et la tristesse en particulier - sont des réactions ultimes à nos traumatismes, nos recours homéostasique de base. Car, s'il est vrai qu'une personne esclave de ses humeurs, un être noyé dans la tristesse, révèlent certaines fragilités psychiques ou idéatoires, il est tout aussi vrai qu'une diversification des humeurs, une tristesse en palette, un raffinement dans le chagrin ou le deuil, sont la marque d'une humanité certes non pas triomphante, mais subtile, combative et créatice...".
} 
sinal de uma oportunidade revolucionária na luta pelo passado reprimido. E aproveita essa oportunidade para forçar uma determinada época a sair do fluxo homogêneo da história; assim, arranca de uma determinada vida à sua época e uma determinada obra ao conjunto de uma oeuvre [obra]. (BENJAMIN, 2012: 19 -20)

Constelando tensões, o corpo melancólico em Anatomia da Melancolia - experiência I, forja uma dramaturgia que poderia ser vista como uma corporeidade do choque. Essa corporeidade deixa emergir os choques que, tal como rupturas energéticas, condensam-se e se deslocam, construindo uma linguagem para este corpo que autoriza, de certa forma, sua experiência histórica, seu passado reprimido, liberando-o, em alguma medida, do trauma que o constituiu, em vista que esse corpo se torne sua própria mônada 51 . Esse corpo do trauma, pleno de carga melancólica, pode ser visto ele mesmo como uma "paragem messiânica", potência de resistência, sendo suas ações e discurso uma espécie de hipérbole ou manifestação dos sussurros inaudíveis do passado, e que subjazem em nosso cotidiano, no qual o choque tornou-se a norma, tornou-se invisível.

Os choques atravessam Anatomia da Melancolia - experiência I: na primeira cena esses choques são literais, são feitos a partir de

\footnotetext{
51 “Nas visões cósmicas de Giordano Bruno (1548-1600), as mônadas, núcleos divinos de todos os seres vivos, correspondem aos centros de gravitação dos astros" (ROOB, 2001: 13). Segundo Raymond Williams, "o surgimento de noções de individualidade, no sentido moderno, pode ser relacionado com a dissolução da ordem social, econômica e religiosa medieval. No movimento geral contra o feudalismo, houve uma nova ênfase na existência pessoal do homem sobre e para além de seu lugar ou função em uma rígida sociedade hierárquica. No protestantismo, também houve uma ênfase na relação direta e individual do homem com Deus, em oposição à relação mediada pela Igreja. Mas foi apenas no final do século XVII e no século XVIII que uma nova modalidade de análise, na lógica e na matemática, postulou o indivíduo com a entidade substancial (as mônadas de Leibniz), da qual outras categorias, em particular as coletivas derivavam. O pensamento político do Iluminismo seguiu principalmente esse modelo." (WILLIAMS, 2007: 229).
} 
impactos e do lançamento do corpo contra o chão. Em seguida, esses choques se apresentam a partir da dificuldade narrativa, manifestando-se nas interrupções da fala, em frases nas quais as palavras ficam suspensas; em seguida, o choque se faz nas passagens entre a fala e o movimento, como se caminhassem em direções opostas e contraditórias. Esses dispositivos surgem do enunciado "contradições": contradição entre movimento e fala; contradição entre a atmosfera sonora e o deslocamento do corpo; contradição entre um corpo ordinário e um corpo dramático; contradição entre um corpo paralisado e imóvel e uma fala ininterrupta e acelerada; contradição entre as direções internas do movimento; contradições entre gestos externalizados (endereçados ao público) e olhar internalizado (direcionados ao vazio interno do corpo, mergulhados em um ego ausente). Contradições cujos investimentos energéticos propunham, invariavelmente, a criação de choques, de conflitos, de negações dialéticas internas ao corpo e deste em relação às outras linguagens do espetáculo, criando vetores negativos em combate entre si, fazendo emergir o choque em uma trajetória composta por rupturas e suspensões.

A dramaturgia se fazia, assim, a partir de uma elaboração dos traumas, na medida em que se repetiam violentamente os gestos e as palavras, procurando trazer à tona a experiência do choque que havia sido reprimida. A partir dos "enunciados contraditórios", o corpo se colocava em experiência/investimento físico e libidinal, em "trabalho" sobre o trauma e, desse modo, se fazia possível a criação de uma trajetória e de uma dramaturgia melancólicas.

Regido por dinâmicas contraditórias, composto do choque entre forças opostas que operam simultaneamente, forjava-se um terceiro corpo: um corpo no limiar da paralisia e do furor, do abatimento e da 
acelerada reflexão, da prostração e da ação. Este "terceiro" é o que eu chamaria de uma corporeidade melancólica, linguagem caracterizada por passagens, por limiares de diversos corpos em choque em um mesmo corpo. Essa corporeidade não poderia ser entendida como uma síntese, resolução final da dialética: trata-se de uma espécie de dialética sem síntese, uma contradição na qual as forças simultâneas permanecem em choque sem nunca chegar a um equilíbrio, equilíbrio esse que anularia a carga melancólica deste corpo, levando-o a uma espécie de redenção (que para o melancólico está fora de alcance). Esse corpo constela, assim, em suas descargas energéticas e vetores de movimento, as contradições por ora - insolúveis de sua história e época.

Em nossa constituição moderna, tal como foi empreendida pela ideologia do progresso, o sujeito privado passa a ter valor superior (e de domínio) sobre a esfera pública, em uma cisão crescente entre vida privada e vida pública. $\mathrm{O}$ sujeito da modernidade foi sendo expropriado (sem interesse libidinal) de seu exercício público, cindido de seu interesse coletivo, de sua ação enquanto sujeito histórico ${ }^{52}$. Esta ausência fundamenta a melancolia do corpo moderno: falta-lhe uma corporeidade que conjugue libido e história política, falta-lhe, no limite, um corpo de resistência cujo "eu" estaria, inerentemente, implicado a uma história social e partilhada.

\footnotetext{
52 "Segundo Habermas, a partir do século XVI (...), o poder público se consolida em algo antitético e que apenas é tangenciável por aqueles que lhe são meros subordinados e que, de início, só encontram nele a sua própria negação. Nesse sentido estrito, "público" é sinônimo de estatal; o atributo não se refere mais à "corte" representativa de uma pessoa dotada de autoridade, mas sobretudo ao funcionamento regulado pela competência, de um aparato dotado do monopólio da violência. A dominação feudal transforma-se em "polícia": as pessoas privadas que lhe são submetidas formam o público, enquanto destinatários do poder público. O publicum se transforma em público, o subjectum em sujeito, o destinatário da autoridade em seu adversário. Surge o conflito entre esfera pública e mundo privado, Estado e citoyen"(MATOS, 2016: 452).
} 
Esta corporeidade melancólica pode ser descrita como uma constelação composta nos limiares de fluxos e paragens corporais e fluxos e paragens históricos, uma reunião de estrelas que, embora dispersas, com rupturas e hiatos entre si, organizam uma determinada unidade espacial. Um investimento melancólico faria emergir uma linguagem desviante, que lança um estranho olhar hiperbólico em relação à realidade, operando em um espaço de limiar do sujeito individual e do sujeito coletivo, ou ainda, do sujeito privado e do sujeito público. Esta corporeidade caracteriza-se por uma reunião não harmônica de forças de choque consteladas nos deslocamentos e fluxos deste corpo. Os investimentos e pulsões físicas que agem e ocupam esse corpo, tais como o abatimento, a tristeza, a ausência de afetos "felizes" que caracterizaria, em certa medida, a "indolência do coração",53 do melancólico são, assim, integrantes de uma indolência social e histórica que se encontra hiperbolizada nesta corporeidade melancólica.

Para Quinet, a ideia de felicidade compreende formas de existência buscadas pelo ser humano para obtenção de prazer. No entanto, essa busca traz consigo um inevitável desprazer por nos sabermos finitos. Vivemos, em nossa arruinada modernidade, na tensão entre o desejo de ser um outro, feliz, e de, evidentemente, jamais sê-lo por completo, dada que não há uma vida sem rupturas, uma vida "ideal”, desprovida de choque, de conflito, de contradição:

(...) Lacan faz uma articulação da ética com a política que é relativa à questão da felicidade. (...) É nesse contexto que Lacan se refere à Saint-Juste - filósofo revolucionário e político cuja verve era veemente e intensa. Uma de suas frases (...) é a seguinte: "A

\footnotetext{
${ }^{53}$ BENJAMIN, Walter. Origem do drama trágico alemão. Belo Horizonte: Autêntica, 2013.
} 
felicidade é algo novo na Europa." Essa é sua frase mais conhecida mas Lacan vai tomar uma outra - "A felicidade tornou-se um fator da política" - que traduz da seguinte forma: "Não poderia haver satisfação de ninguém sem a satisfação de todos.”. (...) É a partir justamente dessa concepção da felicidade como um bem comum, como algo partilhado, ligado à satisfação, que vai aparecer a psicanálise. (...) A felicidade é concebida segundo Kant (...) como uma harmonia sem rupturas com a vida. (...) O impossível é essa "concordância sem rupturas com a vida" como se pode ter uma vida sem rupturas? Nesse "não poder desejar o impossível" a falta já está implicada (...). (QUINET, 2009: 45-46)

Enquanto o mundo liberal impinge ao indivíduo a busca por sua felicidade, sem rupturas (já que a história social, esta "satisfação de todos", se tornou um objetivo longínquo do qual parecemos não fazer parte), este afasta-se mais e mais do que seria seu verdadeiro outro, seu estranho familiar (o objeto de falta do melancólico), a saber, a própria história partilhada, comum, que permanece amortizada pelo fetiche da ideologia liberal. Para Saint-Juste, a felicidade é um direito e essa não se traduz por uma harmonia sem conflito, mas está justamente na luta, se faz dos choques, rupturas, quedas, fracassos, do combate entre fios da história tensionados. Essa ideia de felicidade assemelha-se, portanto, à corporeidade melancólica da qual falamos.

É justamente esta "falta já implicada", o motor e potência de ação do corpo em Anatomia da melancolia - experiência I: um corpo que se debate sob as tensões e choques de seus membros contra o chão, interiorizando e hiperbolizando o próprio movimento histórico, como se esses membros fossem os vetores dos acontecimentos em choque dialético entre si. Os deslocamentos e choques físicos se tornam assim a própria hipérbole dos deslocamentos e rupturas da história. Este trabalho 
- a ação de deixar emergir e de se mover dentro do choque - retira o corpo melancólico da prostração que lhe foi designada em um primeiro momento, colocando-o em movimento. Não poderíamos dizer que o corpo melancólico não carrega em si um "afeto feliz", porém não se trata de um afeto sem rupturas, mas de uma felicidade do choque, uma felicidade que só se satisfaz se capaz de religar o indivíduo ao seu estranho, ao comum e partilhado, como pensou Lacan. Valeria nos perguntar se, contrariamente ao que parece, não seriam os corpos entendidos como "não melancólicos" (aqueles adequados à ordem e à proporção da realidade) que estariam, esses sim, em uma inércia paralisante, caminhando sem contestação, sem rupturas, sem resistência e positivamente pelas ruas, sem atentar para as sombras do passado esquecidas nas esquinas, sombras reveladoras de nossa miséria comum.

Julia Kristeva nos diz: "Nada mais triste do que um Deus morto." (1987: 18). Por que nos sentimos tão infelizes se conseguimos, como seres humanos modernos, substituir Deus pela racionalização da vida? E se a felicidade não reside mais em uma unidade divina que legitimou a Idade Média, nem apenas na razão iluminista, onde ela estaria?

Nas sociedades moderna e contemporânea, a ideia de felicidade está associada à busca de harmonia, a um uno idealista, indivisível, que justamente acaba por aniquilar o necessário trabalho dialético com os antagonismos e choques que a história promove. Este corpo melancólico, ao contrário, acaba por expor esses antagonismos, negando o ideal harmônico e evidenciando as contradições e choques que comporiam o afeto "feliz": não seria este o exercício de uma construção permanente da felicidade em uma outra coerência, a saber, contraditória?

A potência desse exercício talvez esteja no vazio traumático do melancólico que é preciso escavar, potência por vezes inaudível sob o 
vazio dos corpos exterminados nos quais, todavia, fulgura ainda a mônada ${ }^{54}$ que se instaura no limiar do sujeito e mundo. Nessa mônada, passado e presente se conjugam em um cristal da história que deve ser apreendido em um esgrima de vida e morte, abrindo espaço para que irrompa uma felicidade partilhada: este unheimlich, estranho familiar que move o corpo melancólico.

A corporeidade melancólica enquanto um "afeto triste", mas que carrega sua "sombra feliz", seu ideário, deriva assim, da separação traumática entre sujeito e história, do fato de o homem moderno não ser mais capaz de criação de uma experiência coletiva. Da privação de uma linguagem que "religue" o eu a seu outro eu, à sua história social, advém este corpo desidentificado com sua época (seu sentimento é de inadequação) e abatido por ela, em falta (ausência) de uma subjetividade histórica (massacrada pelo progresso técnico da modernidade), corpo em falta, esvaziado de sua própria linguagem e trajetória. Não estaria nesta tristeza traumática a sombra de sua linguagem perdida? Não seria este vazio repleto de sombras, de rastros do passado, que caracteriza a corporeidade melancólica, a fonte de sua própria linguagem? Em seu artigo Vazio e criação, Jean Starobinski (1990) escreve:

Que um futuro, mesmo se nada se produz, permaneça aberto diante da consciência - o vazio então muda de significação. Uma plenitude se torna possível. À espera do que poderia o preencher, o vazio não é mais o fim do mundo: não é mais o luto, mas o acolhimento virtual que marca a qualidade do vazio (...) a alma deve alcançar a perfeição do vazio (...) (STAROBINSKI, 1990: 41)

\footnotetext{
${ }^{54}$ Falaremos mais precisamente sobre este termo no capítulo seguinte.
} 
O vazio melancólico não seria, portanto, uma ausência sem significado. Se para este corpo o mundo perdeu sua razão e sentido, é em sua corporeidade da falta que ele poderia reencontrá-la. Este corpo não espera ser preenchido, ele é em si mesmo um preenchimento, está pleno de uma qualidade de linguagem que nasce desta espécie de "perfeição do vazio".

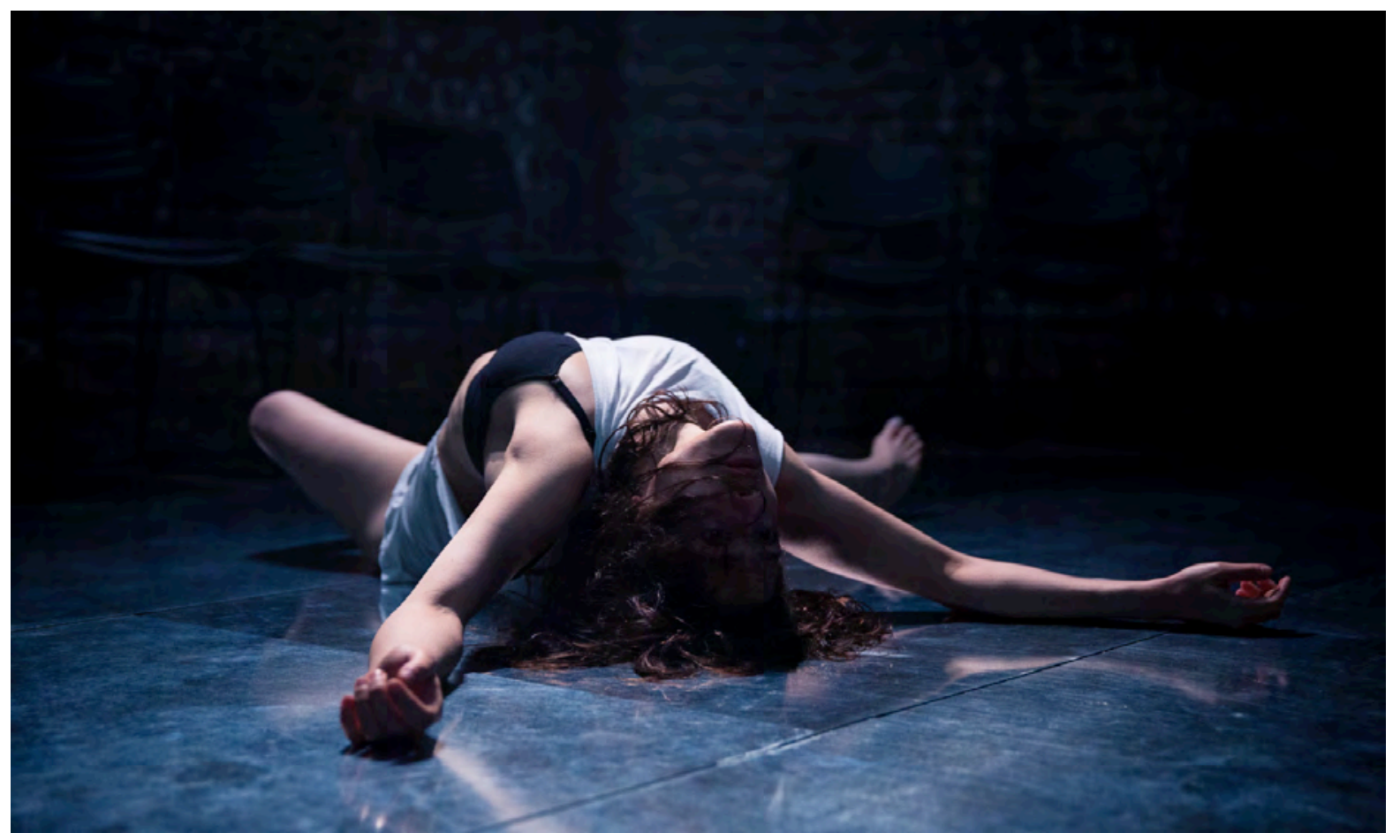

Imagem 2. ESPASMOS HIPERTÔNICOS. Anatomia da Melancolia - experiência I. Foto: Otávio Dantas. 


\title{
CAPÍTULO 2
}

\section{RASTROS E IMAGEM DIALÉTICA}

\begin{abstract}
"Para ser autêntica, a cultura precisa imergir no elemento destrutivo, reconhecer essas coisas na escuridão como suas; caso contrário, ela adoecerá com a neurose que surge da repressão."
\end{abstract}

Terry Eagleton.

O corpo melancólico está na contradição entre assimilação e negação de seu contexto. Se o presente lhe parece incompreensível e, diante do mesmo, ele sente uma total desertificação, desidentificação e esvaziamento de um sentido no mundo e de um sentido "de si mesmo", seria talvez escavando este vazio, recolhendo os rastros recalcados do passado, que parece encontrar as origens e a compreensão da miséria que vê à sua frente. Miséria que assume e assimila em sua própria corporeidade (também ele se reconhece miserável e finito) e, em uma dinâmica dialética, nega e rejeita essa mesma miséria.

Esta corporeidade melancólica, funciona tal qual uma mônada:

A interpretação das obras de arte como processo em si imobilizado, cristalizado, imanente (stillgestellten, krystallisierten, immanenten Prozesses) aproxima-se do conceito de mônada. (...) A constituição monadológica das obras de arte em si vai além de si mesma. Se for absolutizada, a análise imanente tornase presa da ideologia contra a qual lutava ao querer imiscuir-se nas obras, em vez de delas retirar uma concepção de mundo (anstatt Weltanschauung von ihnen abzuziehen). (...) Nenhum particular (kein Besonderes) é legítimo na obra de arte que, mediante a sua particularização, não se torne também universal. (ADORNO, 2012: 273) 
Segundo a concepção de Adorno, a obra de arte como mônada fechada em si mesma, mas com janelas abertas ao mundo - conecta o particular ao universal, o mundo ao "si mesmo". Esse corpo de conexão forja sua ontologia em um terceiro corpo: não se trata nem do indivíduo nem da sociedade, mas esse corpo melancólico - sua corporeidade mesma - se instaura nos limiares do particular e do universal, fisicalizando uma "subjetividade do limiar". A trajetória dramatúrgica do corpo, configurado em Anatomia da Melancolia - experiência I, poderia ser vista como uma mônada que busca ressignificar a experiência social de nosso contexto histórico:

Contrariamente às notícias de jornal, baseadas na lógica moderna da medição e da verificação empírica, a relação entre narrativa e experiência não é da ordem da plausibilidade interna, mas reside na analogia "monadológica" entre o particular e o universal: a narrativa, enquanto mônada, reproduz o macrouniverso da experiência humana com todos os seus mistérios. O caráter enigmático da narrativa reproduz os enigmas do mundo; ela não oferece uma solução para esses enigmas, mas os torna mais suportáveis pelo próprio ato da reprodução. (OTTE, 2012: 64-65)

Trata-se de uma dramaturgia que não oferece uma superação para os conflitos e contradições de seu tempo histórico mas, ao elaborá-los em sua própria corporeidade, traz à tona essas contradições. Uma corporeidade melancólica que se "manifesta nas contradições" caracteriza-se por gestos e intenções de movimento em choque e em relação mútua. É importante notar que a lógica formal, de viés aristotélico, ainda estrutura a visão hegemônica do mundo burguês e civilizado-capitalista, em que a contradição é sinônimo de "erro" e o 
pensamento apresenta dificuldades para raciocinar a partir da filosofia dialética desencadeada pelas contradições e pela negatividade:

Sendo cada um para si, enquanto não é o Outro, aparece cada um no Outro, e só na medida que o Outro é. (...) Na doutrina dos conceitos contraditórios, um dos conceitos significa, por exemplo, azul, o outro significa não-azul, de modo que este Outro não é algo afirmativo, como seria, digamos, amarelo; mas somente deve afirmar-se como sendo o negativo. (...) Positivo e negativo são portanto essencialmente condicionados um pelo outro, e só existem em relação recíproca. $\mathrm{Na}$ contradição, o diferente em geral não tem frente a si somente um Outro, mas o seu Outro. Tudo é contradição. Não há de fato em lugar algum nem no céu nem na terra, nem no mundo espiritual, nem natural, um tão abstrato ou-ou tal como o entendimento afirma. Tudo, seja o que for, é um concreto; por conseguinte, é em si mesmo algo diferente e oposto. Em geral, o que move o mundo é a contradição; e é ridículo dizer que a contradição não se deixa pensar. (HEGEL, 1995: 235-238)

Uma alma hiperbólica parece gritar e contestar a falsa ordem imposta pelo dogmatismo ideológico moderno, baseado no apagamento e apaziguamento dos corpos melancólicos. Todavia, como na modernidade e hipermodernidade na qual vivemos, "tudo o que é sólido desmancha no ar" 55 , passa a ser difícil identificar qual o "trabalho" que pode ser feito diante deste vazio de sentido. Encontramo-nos impotentes diante de nossa miséria cotidiana - que está dada - e que aparentemente não irá

\footnotetext{
${ }^{55}$ Referência à frase de Marx e à obra homônima de Marshall Berman (2014). Segundo Marx: "todas as relações fixas, enrijecidas, com seu travo de antiguidade e veneráveis preconceitos e opiniões, foram banidas; todas as novas relações se tornam antiquadas antes que cheguem a se ossificar. Tudo que é sólido desmancha no ar, tudo que é sagrado é profano, e os homens finalmente são levados a enfrentar (...) as verdadeiras condições de suas vidas e suas relações com seus companheiros humanos." (MARX \& ENGELS. O manifesto comunista. São Paulo: Boitempo, 1998: 23).
} 
sucumbir tão prontamente.

Tomando-se esta corporeidade melancólica como um desvio, como uma instauração de distância para uma abertura de construção crítica (espécie de estranhamento "do real" para reencontrarmos "o real"), podemos dizer que seus característicos furores e abatimentos se encadeiam em um processo dialético de distanciamento e aproximação a uma miséria "macrossubjetiva". A partir da relação negativa entre assimilação e destruição (assimila a miséria para corroê-la por dentro), como falamos a respeito da poética de Baudelaire anteriormente, seria possível revelar a realidade e se ver revelado nela e por ela, em uma espécie de "refamiliarização" a partir da desfamiliarização, movimento dialético do qual emerge nosso exercício de alegorização do real e que impulsiona nossa dramaturgia melancólica.

Segundo Berlinck (2008), a sociedade hipermoderna é uma sociedade de imagens e, assim, "as imagens do outro nos são oferecidas em profusão, massivamente, ininterruptamente. As imagens parecem preencher todo o tempo e todo o espaço real e imaginário, elas parecem ser tudo e todo o real, não há falta, não há lacuna, não há ausência." (BERLINCK, 2008: 50). O sujeito, imerso neste mundo de representações especulares e espetaculares, "não simboliza, aceita como sua essa realidade "mais que real", acreditando ver nela seu próprio reflexo (tem a ilusão de onipotência)." (Idem). A experiência do vazio melancólico, adviria "da distância entre o indivíduo e a imagem desejada e desejável que parece refleti-lo como um espelho, por sua irrealidade é totalmente inalcançável. Por isso, identificando-se com a imagem, sentese distante de si e experimenta uma perda contínua." (Idem).

Contradizendo esta ideia unívoca da imagem como uma hiperrealidade que nos é imposta e resistindo a essa realidade "mais que real", 
este corpo melancólico se propõe a um exercício dialético entre sua vivência e capacidade de estranhamento e contemplação das imagens que formam o mundo. A partir deste "desvio", de uma "tomada de distância", poderíamos talvez elaborar criticamente esta hiper-realidade, ou seja, transformar esse conflito em linguagem deste corpo melancólico, naquilo que nomeio "corporeidade da contradição".

Esta corporeidade opera em dupla direção: assimila as imagens do mundo e as destrói a partir de seus dispositivos corporais. Como um raio - que separa a claridade do breu, ao mesmo tempo que os fusiona e os revela - opera-se um choque entre esta imagem do mundo (partilhada por uma comunidade humana) e a imagem projetada por este corpo melancólico (do indivíduo), evidenciando as inúmeras rupturas temporais e suspensões entre essas duas imagens, entre o indivíduo e sua comunidade. Esse duplo movimento pode ser descrito a partir da imagem dialética ${ }^{56}$ de Walter Benjamin, ideia sobre a qual nos deteremos adiante. Movida por dispositivos dialéticos, essa corporeidade da contradição procura recriar a partir de uma imagem/imaginação cênica, uma experiência autêntica ${ }^{57}$ de si e do mundo, elaborando este vazio, devolvendo ao corpo alguma fagulha de compreensão sobre si mesmo em sua relação com o mundo. Seria nossa capacidade de espanto, de choque,

\footnotetext{
56 “(...) Benjamin pôs a imagem no centro nevrálgico da vida histórica. (...) compreendeu que um tal ponto de vista exigia a elaboração de novos modelos de tempo, levando a cabo uma crítica da visão positivista e progressista da história. A imagem não está na história como um simples ponto sobre uma linha. Ela possui uma temporalidade de face dupla, precisamente como imagem dialética (...)." (CANTINHO, M.J., 2008: 3).

${ }^{57}$ Sobre o que seria essa autenticidade, podemos entendê-la ainda, a partir de seu contrário: “(...) aqueles que meditavam e iam mais fundo viam-se na existência como num campo de ruínas preenchido por ações não concluídas e inautênticas." (BENJAMIN, Walter. Origem do drama trágico alemão. Belo Horizonte: Ed Autêntica, 2013: 144.)
} 
de reconhecer o estranho nas imagens do mundo e em si, a base dessa corporeidade.

Para Benjamin, o conceito de experiência se liga à ideia de "tradição" no sentido daquilo que "transcende a vida e a morte particulares", daquilo que é compartilhado "por uma comunidade humana" (GAGNEBIN, 2009: 50). A tradição, para Benjamin, representa assim uma experiência compartilhada, comum, refere-se à experiência de vida de um indivíduo em uma determinada coletividade: a tradição se faz, portanto, no limiar da vida particular e da vida de uma sociedade, sendo ainda algo que ultrapassa os parâmetros progressistas da história que supõem uma separação entre vida e morte, finito e infinito, eu e o mundo, particular e público, etc.

O vazio melancólico parece indicar justamente a ausência de uma imagem da história que conecte este corpo a uma comunidade humana, a seus antepassados e tradições, que conecte a experiência do indivíduo a uma experiência comum. Sob a ideia benjaminiana de tradição podemos entender que esta se constrói no limiar da vida/morte de um indivíduo e da vida/morte da história de uma sociedade. É por esse motivo que Benjamin relacionará a ideia de uma experiência autêntica a um tempo messiânico, a um tempo que não está subjugado ao "historicismo vulgar", à temporalidade que, na modernidade, passa a ser ditada pela reprodutibilidade técnica: "A percepção lúcida de uma nova época, a da reprodutibilidade e da técnica, (...) passa por uma compreensão das novas modalidades de relação do homem com a tradição, com a linguagem, a história, o conhecimento" (CANTINHO, 2008: 3). Essa mutação, base de toda filosofia de Benjamin, "contamina toda uma visão absolutamente diferente da história e do conhecimento e passa, sem dúvida, pela perda 
da visão aurática e nostálgica do passado para uma compreensão dialéctica e crítica (operada pela imagem dialéctica).” (Idem).

$\mathrm{Na}$ leitura que Benjamin faz de sua época, sobretudo a partir de sua análise sobre a primeira guerra mundial, a perda de experiência estaria vinculada, de um lado, ao desenvolvimento das forças produtivas do corpo, à técnica e à mecanização do corpo moderno e, de outro, à impossibilidade de assimilação e de "trabalho" sobre os choques, em vista de torná-los "experiência" para o sujeito. Em nossa vida danificada ${ }^{58}$, o choque que caracterizaria um autêntico estado de exceção, virou a regra:

Nós hoje sabemos que, para a destruição da experiência, uma catástrofe não é de modo algum necessária, e que a pacífica existência cotidiana em uma grande cidade é, para este fim, perfeitamente suficiente. Pois o dia-a-dia do homem contemporâneo não contém quase nada que seja traduzível em experiência (...). O homem moderno volta para casa à noitinha extenuado por uma mixórdia de eventos divertidos ou maçantes, banais ou insólitos, agradáveis ou atrozes -, entretanto nenhum deles se tornou experiência. (AGAMBEN, 2008: 21-22)

Esta incapacidade de transformar uma experiência vivida em experiência autêntica (que tenha uma legitimidade em uma história partilhada) pode ser compreendida como uma impossibilidade de um trabalho de luto, dada a expropriação de nossa capacidade de elaboração

\footnotetext{
${ }^{58}$ Referência ao texto Minima Moralia: reflexões a partir da vida danificada (1944-47) de Theodor Adorno. Retomando os estudos do amigo Benjamin, é da indigência da experiência que Adorno nos fala em Minima Moralia: do empobrecimento que acompanhou a história do mundo capitalista, que se apresenta como ruína, como fragmento de experiência. Se a modernidade é temporalidade reduzida às relações de troca, ao enrijecimento do mundo administrado, à reificação do sujeito, como "sujeitomeio" para uma "razão instrumental-fim", a ideia mesma de experiência, que seria o acesso do sujeito ao mundo, torna-se , então, vida danificada.
} 
da vida "vivida", já arruinada, esvaziada, danificada. Esta elaboração parece exigir um trabalho de rememoração daquilo que foi danificado, que está soterrado e esquecido, a saber, a própria experiência deste corpo comum: corpo mortificado, habitado pelo próprio cadáver de seu corpo partilhado.

É justamente a perda da capacidade de traduzirmos nossas experiências (no sentido de conferir sentido, conhecimento), a origem "da falta" deste corpo melancólico, testemunha inaudível de uma deteriorização e falecimento social contínuos, incapaz de experienciar o choque cotidiano. Esse corpo encontra-se amortizado, anestesiado: seus membros parecem ter sido amputados, os acontecimentos vividos não se tornam experiência e assim, o melancólico se encontra expropriado de sua própria capacidade - e, no limite, de seu direito - de criação e de linguagem.

O capitalismo conseguiu criar uma nova forma de miséria, tratase de uma miséria subjetiva, uma miséria da própria "alma". Uma alma que se encontra mineralizada, marcada pela impotência do corpo de experienciar e de traduzir sua realidade em linguagem; alma que teria sido substituída pela própria mercadoria. Em uma perspectiva histórica, esta alma é o próprio corpo "partilhado", ou seja, a própria comunidade humana, objeto/sujeito faltante a esse corpo melancólico. Sem experiência vivida, autêntica, tampouco há memória; sem memória estamos privados de nosso direito e capacidade imaginativa que poderia conceber uma outra concepção para a anatomia de nossa história. A partir de um trabalho de rememoração do passado podemos imaginar um outro futuro possível, recriando e transfigurando essa anatomia partilhada.

Em nossa hipermodernidade vivemos uma inversão perversa: é a própria realidade que se torna ficção; uma hiper-realidade se torna a 
imagem fantasmagórica e abstrata do capital para qual nossa alma foi vendida:

Hoje a abstração já não é a do mapa, do duplo, do espelho ou do conceito. A simulação já não é a simulação de um território, de um ser referencial, de uma substância. É a geração pelos modelos de um real sem origem nem realidade: hiper-real. O território já não precede o mapa, nem lhe sobrevive. É agora o mapa que precede o território - precessão dos simulacros - é ele que engendra o território cujos fragmentos apodrecem lentamente sobre a extensão do mapa. É o real, e não o mapa, cujos vestígios subsistem aqui e ali, nos desertos que já não são os do Império, mas o nosso. O deserto do próprio real. (BAUDRILLARD, 1981: 8)

Para Benjamin, por outro lado, a pauperização da experiência, que geraria, décadas depois, a nossa hiper-realidade, relaciona-se diretamente à linguagem, à impossibilidade de narrar, de imaginar, posto que a própria memória estaria bloqueada pelo trauma do indivíduo em relação à sua história coletiva. É a capacidade do ser humano de experienciar a realidade que dá origem e acesso à criação, à narração, à linguagem:

Uma coisa é clara: a cotação da experiência baixou, e isso aconteceu com uma geração que fez, em 19141918, uma das experiências mais monstruosas da história universal (...). Não se tinha naquela época, a experiência de que os homens voltavam mudos do campo de batalha? Não voltavam mais ricos, mas mais pobres de experiências partilháveis (...), num campo de forças de correntes e explosões destruidoras, o corpo humano, minúsculo e frágil. (BENJAMIN, 2012c: 86) 
O corpo melancólico, embora tributário desta pobreza e emudecimento, carrega em si, histórica e contraditoriamente, uma potência contestatória, esta sim, indestrutível. Esse corpo é, simultaneamente, sujeito e objeto ${ }^{59}$ : objeto do agenciamento de poderes sociais, econômicos e políticos e sujeito que pode resistir aos mesmos, compondo uma dramaturgia que adviria de seu próprio estado danificado. Para Adorno, a vida danificada é um negativo - o da vida reta, degradada pela existência colonizada pelo império da mercadoria. A vida reta, a vida comum, diz Adorno, foi tornada apêndice do processo de produção material: "Só a pesquisa da sua configuração alienada, das potências objetivas que determinam até no mais recôndito a existência individual, permite conhecer a verdade sobre a vida tal como é dada." (ADORNO, 2008: 99). Trata-se, nessa vida danificada, de um corpo cujo sintoma guarda nostalgicamente seu próprio antídoto; um corpo cujo trauma e potência de cura operam em limiar, relacionando, nesta contradição, passado e presente históricos.

O mundo atual, ruína de um capitalismo tardio ${ }^{60}$, é marcado pela incapacidade de atribuirmos sentido à nossa existência, de traduzirmos nossa vivência em experiência, submetidos que estamos à produtividade de nosso sistema econômico, social e cultural e, contraditoriamente:

\footnotetext{
59 “Trata-se, em outros termos, de chamar a atenção para a práxis histórica, cujo < sujeito > são as forças políticas, trata-se de dirigir a atenção às forças transformadoras e não apenas ter em conta as determinações sócioeconômicas que não levam senão a < objetos >”. (MARTINS, 2014: 10).

${ }^{60}$ Partimos do conceito de Ernest Mandel, que define o capitalismo tardio como o atual terceiro estágio deste sistema, hegemonicamente batizado de globalização. Sucedendo os estágios do capitalismo de mercado e do monopolista ou imperialista, o capitalismo multinacional marca a apoteose do sistema e a expansão global da forma mercadoria, colonizando áreas tributárias de tal forma que não se pode mais falar de algum lugar "fora do sistema", como a Natureza ou o Inconsciente, constantemente bombardeado pela mídia e pela propaganda.
} 
Longe de ser uma festa despretensiosa que se diverte em brincar com os valores, o espetáculo generalizado não seria a expressão mais fria da depressão, a confissão camuflada de uma humanidade melancólica? (KRISTEVA, 1990: 40) (Tradução nossa)

Talvez seja do choque entre a vastidão do espaço vazio do corpo melancólico e nossa sociedade do espetáculo ${ }^{61}$, conformada por imagens, informações que propagam o consumo, onde não há horizonte para o "pássaro onírico do tédio", onde não há tempo nem espaço para um processo de rememoração, que poderemos encontrar uma outra anatomia para nosso corpo histórico esquecido, para a experiência do corpo do "eu" com a história de "muitos", em um tempo do Agora (Jetztzeit)"62. Este corpo melancólico poderia ser entendido como um narrador "[cuja] marca própria é a de uma absoluta ausência de ilusões sobre a época, aliada a uma total identificação com ela” (BENJAMIN, 2013a: 87). Sua linguagem estabelece-se a partir de um desvio: sua atitude é contraditória, no limiar da distância e da proximidade, próximo da mercadoria, porém sem se confundir com ela. Benjamin assim define a crise da experiência que marca a sociedade moderna:

\footnotetext{
${ }^{61}$ DÉBORD, Guy. La Société du Spectacle (Paris, 1967): “O espetáculo é ao mesmo tempo parte da sociedade, a própria sociedade e seu instrumento de unificação. Enquanto parte da sociedade, o espetáculo concentra todo o olhar e toda a consciência. Por ser algo separado, ele é o foco do olhar iludido e da falsa consciência; a unificação que realiza não é outra coisa senão a linguagem oficial da separação generalizada. $O$ espetáculo não é um conjunto de imagens, mas uma relação social entre pessoas, mediatizada por imagens." (cap. 3 e 4 ).

62 “A história é objeto de uma construção cujo lugar é constituído não por um tempo vazio e homogêneo, mas por um tempo preenchido pelo Agora (Jetztzeit). (...) O Agora (Jetztzeit) que, como modelo de tempo messiânico, concentra em si, numa abreviatura extrema, a história de toda a humanidade, corresponde milimetricamente àquela figura da humanidade no contexto do universo (...). [O historiador] fundamenta um conceito de presente como "Agora' (Jetztzeit), um tempo no qual se incrustaram estilhaços do messiânico.” - Teses XIV e XVIII. (BENJAMIN, 2013a: 18-20).
} 
Pobreza de experiência: a expressão não significa que as pessoas sintam a nostalgia de uma nova experiência. Não, o que elas anseiam é libertar-se das experiências, anseiam por um mundo em que possam afirmar de forma tão pura e clara a sua pobreza, a exterior e também a interior, que daí nasça alguma coisa que se veja. (BENJAMIN, 2013a: 89)

Mais do que uma nostalgia por um passado perdido, o melancólico ressente a ausência de uma utopia forjada na relação entre seu passado e seu presente, da ligação de seu "eu particular" ao seu "eu partilhado". Benjamin (2013a) nos diz ainda:

Esse gigantesco desenvolvimento da técnica levou a que se abatesse sobre as pessoas uma forma de pobreza totalmente nova. (...) Na verdade, de que nos serve toda a cultura se não houver uma experiência que nos ligue a ela? (...) (Ibidem: 86-87)

Segundo Benjamin, Baudelaire teria emprestado uma forma alegórica a esta nova pobreza moderna, pois é a partir dos restos esquecidos na rua, do próprio lixo moderno dispensado cotidianamente, que Baudelaire constrói sua poesia. Em sua obra, a matéria da melancolia é a relação do indivíduo com o espaço público da cidade, indivíduo que está marcado pela perda do pertencimento a formas comunitárias de convívio. Tal qual a atitude baudelairiana ${ }^{63}$, Benjamin propõe uma

\footnotetext{
${ }^{63}$ Em "A Modernidade", de A Paris do Segundo Império em Charles Baudelaire, Benjamin traz, não por acaso, um poema em que Baudelaire descreve a vida dos trapeiros em Paris: "Aqui temos um homem, ele tem de recolher na capital o lixo do dia que passou. Tudo o que a cidade grande jogou fora, tudo o que ela perdeu, tudo o que desprezou, tudo o que destruiu, é reunido e registrado por ele. Compila os anais da devassidão, o cafarnaum da escória; separa as coisas, faz uma seleção inteligente; procede como um avarento com seu tesouro e se detém no entulho que, entre as maxilas da deusa indústria, vai adotar a forma de objetos úteis ou agradáveis". (BENJAMIN, 2000: 78)
} 
concepção e leitura histórica construídas a partir dos rastros (daquilo que foi descartado pela história oficial, relegado ao esquecimento). Diz Jeanne Marie Gagnebin, que a historiografia crítica de Benjamin procura por rastros "deixados pelos ausentes da história oficial (os oprimidos, die Unterdrückten), à revelia da historiografia em vigor". Procurar por aquilo que escapa ao controle da versão dominante da história, significa, então, introduzir "na epicidade triunfante do relato dos vencedores um elemento de desordem e de interrogação". Esses rastros são pouco visíveis num duplo sentido: "não se destacam, não são os traços dominantes de uma época, e também são muito mais detalhes que parecem aleatórios, restos insignificantes que, à primeira vista, poderiam e deveriam ser jogados fora." (GAGNEBIN, 2012: 33).

Os rastros são aquilo que escapa à produção capitalista: o descarte, o mendigo, o trapeiro, o Lumpensammler de Benjamin, figura tanto real quanto alegórica e que representa os detritos da história (não oficial). A tarefa deste corpo melancólico, tal qual a do historiador, segundo Benjamin, seria o de reler a história - e recriar (traduzir) o passado - a partir dos fragmentos esquecidos:

Esse narrador sucateiro (o historiador também é um Lumpensammler) não tem por alvo recolher os grandes feitos. Deve muito mais apanhar tudo aquilo que é deixado de lado como algo que não tem mais significação, algo que parece não ter nem importância nem sentido, algo com que a história oficial não sabe o que fazer. (GAGNEBIN, 2009: 53-54)

Enquanto recolhe os detritos, este corpo rememora o passado e lhe atribui um novo significado. Os objetos e seres humanos descartados escapam ao controle do próprio progresso que os criou, escapam à versão 
dominante de nossa história presente e pregressa, propondo uma outra ordem para sua trajetória, melancólica e, de algum modo, subversiva (pois não oficial, à margem da norma), desprovida de uma legitimação normativa, desintegrada do corpo legal, esvaziada da ordem conhecida e dominante. O melancólico benjaminiano poderia ser entendido como um sujeito que se sente apartado da dimensão pública, tão assustadora que ganha feições de barbárie e que é oposta ao espaço individual do lar: "a modernidade não tem mais como oferecer segurança ao indivíduo, de modo que a 'nova barbárie' seria a única reação adequada". No entanto, no processo descrito por Benjamin, a reação do burguês civilizado é outra: "Ao partir para a defesa do próprio lar e da propriedade, ele quer se sentir em casa (...). O espaço e o tempo da cidade grande são marcados por choques constantes, de modo que o burguês tem que fugir para a ilha do seu apartamento para, na falta de um referencial universal, garantir um sistema mínimo de referências privadas dentro de suas quatro paredes. (OTTE, 2012: 75-76)

Se, na modernidade baudelairiana e benjaminiana, os choques eram ainda constantes, em nossa hipermodernidade a distância temporal e espacial necessária à reflexão sobre o trauma, sequer existe e, tampouco, um referencial de orientação universal (que não o próprio capital). Sem, todavia, estabelecer uma ruptura em relação à modernidade (mas acirrando suas contradições), a corporeidade melancólica funda-se ainda mais neste isolamento do indivíduo, consequência de um capitalismo tardio - hipermoderno - que tem a propriedade privada como princípio e condição de existência na grande cidade. A ideia de um corpo isolado, sem correspondência com o mundo ao redor, desprovido de referências partilhadas é uma das marcas deste corpo melancólico, corpo que se encontra lançado em um espaço 
temporal cujas referências históricas foram perdidas: descartadas como restos. Esse corpo se encontra encapsulado e protegido de seu contexto que para ele perdeu o sentido: "trata-se de uma 'natureza morta', fossilizada, que, em sua forma petrificada, reforça a inadequação entre a imobilização do burguês 'encapsulado' em seu apartamento e a movimentação urbana ao seu redor" (OTTE, 2012: 77). Mas essa cápsula não é a mônada que reflete o universo da cidade, mas uma proteção contra esse universo: "no lugar da integração prevalece o retrato do isolamento, reforçado por uma espécie de blindagem com a qual esse burguês se defende do assédio da população urbana.”. Na precisa definição de Otte, na "falta de analogias (...) entre o microuniverso da moradia e o macrouniverso da cidade, a sociedade burguesa cria minicápsulas pré-formadas para receber seu conteúdo." (Idem)

Embora tributário desta falta de referências, o corpo em Anatomia da Melancolia - Experiência I, busca uma ação contrária ao próprio isolamento, motivado por um desejo de redenção ${ }^{64}$. Tal como o catador de lixo, esse corpo recolhe os rastros de sua experiência danificada, na forma de pedaços de gestos e de palavras que consegue "lembrar", e a partir dos quais seria possível rememorar, ainda que parcialmente, sua história de mundo que fora descartada, recriando correspondências entre o passado e o presente e tentando criar uma linguagem a partir de sua própria miséria de experiência: "na ideia que fazemos da felicidade vibra também inevitavelmente a da redenção. $O$ mesmo se passa com a ideia de passado de que a história se apropriou. O passado traz consigo um index

64 “O Messias chega (...) quando sua vinda se realizou tão integralmente que o mundo já não é profano nem sagrado, mas liberto - sobretudo da separação entre profano e sagrado. (...) A redenção (Erlösung), em Benjamin, não se confunde, portanto com a Aufhebung (superação) hegeliana (...). Se a redenção livra, é porque destrói e dissolve, não porque mantém e conserva. E o Messias nos livra justamente da oposição entre o histórico e o messiânico, da oposição entre o profano e o sagrado." (GAGNEBIN, 2014: 192) (Grifo nosso) 
secreto que o remete para a redenção.”. Essa redenção, de que nos fala Benjamin, estaria ligada a uma outra forma de experienciar o tempo: "Não passa por nós um sopro daquele ar que envolveu aqueles que vieram antes de nós? Não é a voz a que damos ouvidos um eco de outras já silenciadas?." Conclui o filósofo alemão que "a ser assim, então existe um acordo secreto entre as gerações anteriores e a nossa." (BENJAMIN, 2012b: 10)". Este acordo pode ser definido como a maneira messiânica de conjugar passado e presente, na tentativa de dar outros rumos à locomotiva da história: "Então, fomos esperados sobre esta Terra. Então, foi-nos dada, como em todas as gerações que nos antecederam, uma tênue força messiânica a que o passado tem direito. Não se pode rejeitar de ânimo leve este direito. E o materialista histórico sabe disso." (Idem).

Já dissemos acima que, para Freud, o sujeito existe justamente no que foi apagado e esquecido, no que foi descartado, portanto. O que parece ter sido esquecido são rastros deixados pelo passado e que guardam em si um index secreto do qual nos fala Benjamin, a que se pode atribuir uma força messiânica que atravessa nosso corpo hipermoderno e que se faz ver na "sombra que recai sobre o melancólico" 65. O trauma, ainda que index danificado, subjaz ao esqueleto insepulto de uma história coletiva e social massacrada; as palavras reprimidas dos vencidos permanecem materialmente presentes, como rastros, termo que "ambiguamente, aponta para uma presença e uma ausência. Aquilo que resta de um passado, de uma trajetória, pode constituir uma base para tentar compreender o que ocorreu a um

\footnotetext{
65 "A sombra do objeto caiu sobre o melancólico (...). Mesmo que 'o êxtase não visite jamais seu coração', o poeta [Baudelaire] é uma 'alma hiperbólica' em direção 'à bondade daquele que tudo nomeia' (...). Ela [a melancolia] o condena a se debruçar sobre si mesmo, permanente vigilante da noite, inspetor inconsolável." (KRISTEVA, 1990: 45) (Tradução nossa).
} 
indivíduo ou a uma sociedade." (SEDLMAYER e GINZBURG, 2012: 8). Para os autores, é possível dizer que "lidar com um rastro exige contemplar o que restou, dentro de um horizonte em que houve perda.". $\mathrm{O}$ rastro nos leva, ainda, a pensar a respeito do tempo: continuidade e ruptura, unidade e dispersão. Um rastro, segundo Sedlmayer e Ginzburg, permitiria "pensar a respeito daquilo que escapa à consciência. Nessa reflexão, a presença da morte é fundamental.” (Ibidem: 9).

Se, para Walter Benjamin, a experiência teria sido completamente destruída, a partir do que refletimos até o momento, uma vivência, por mais traumática que seja (e talvez ainda mais por isso), deixa rastros que ecoam do silêncio dos crimes passados. Na corporeidade melancólica de Anatomia da melancolia - experiência I, esses rastros se chocam em uma corporeidade marcada justamente por uma dinâmica contraditória, construída por continuidades e rupturas, caracterizada pela unidade e pela dispersão dos movimentos - rastros da história - deste corpo individual e social. Eu justapunha gestos que recolhi de desconhecidos da rua que eu identificava como "corpos isolados" 66 , juntamente aos gestos que minha avó fazia já em seu estado de demência final e a movimentos originados dos enunciados contraditórios que criei a partir do material teórico estudado. Esses rastros da minha experiência e os rastros da pesquisa teórica se sequenciavam na dramaturgia do corpo porém, a todo momento, eu impunha suspensões e rupturas em sua execução.

\footnotetext{
${ }^{66}$ Durante quatro meses, uma vez na semana, eu ia a um café onde encontrava uma mesma senhora que sempre comparecia a este local, no mesmo horário. Ela tomava o mesmo café com leite e uma bomba de chocolate. Eu observei suas mãos que pegavam o doce e sua boca que o mastigava. Observei também seu olhar sempre distante, como o olhar de alguém que "não está". Esse foi um dos gestos incorporado à Anatomia da melancolia - experiência I. Minha avó sempre erguia as mãos no ar tentando alcançar alguma coisa a sua frente que "não existia.". Como ela não mais falava e apenas gemia, eu nunca pude identificar que objeto ausente - mas presente para ela - era este que ela procurava. Talvez quisesse apanhar no ar sua própria redenção.
} 
Aquilo que "resta" de um passado social e cultural (que por vezes "escapa à consciência") constitui-se como material para uma dramaturgia que desejou reconstruir uma experiência histórica perdida. Dado que os rastros sempre estarão ali - ainda que sua presença só possa ser percebida devido à uma ausência -, a experiência seria portanto indestrutível, no sentido de poder ser reconstruída ou rememorada a partir dos restos que sua presença/ausência deixou.

A própria linguagem de Benjamin forma-se e instaura-se a partir de passagens, pistas, fragmentos. Um exemplo claro dessa característica é a obra Passagens, as Teses sobre o conceito de história ou ainda, Rua de mão única:

“(...) cabe levar em consideração também a própria escrita benjaminiana e seu caráter 'indiciário' (...) uma das marcas do gênero ensaio." (OTTE, 2012: 81)

Podemos entender que a forma da escrita adotada pelo pensador é a expressão de um corpo/pensamento moderno messiânico, composto por índices de diferentes épocas que operam passagens entre si, compondo uma constelação: uma linguagem forjada das conexões e correspondências entre os rastros do projeto moderno que decanta em nossa miséria hipermoderna contemporânea.

Esta forma adotada por Benjamin é próxima da composição dramatúrgica de Anatomia da Melancolia - experiência I, cuja trajetória é também feita de rastros e índices de um corpo melancólico, no qual cada membro se encontra isolado entre si (inúmeras vezes todo o corpo se encontra paralisado, enquanto apenas uma mão procura emergir do chão, em um pequeno gesto feito com grande esforço e que procura, insistentemente, sua integração em uma unidade corporal). Os gestos 
operam passagens entre si igualmente, não sendo possível vislumbrar uma forma humana bem delimitada. Uma constelação de ruínas parece se formar ao longo desta trajetória de passagens, compondo não mais um corpo "total", uno e indivisível (o que seria historicamente um contrassenso e uma impossibilidade), mas talvez uma linguagem, esta sim portadora de certa coerência - constelar (tal como a escrita benjaminiana) - feita de rastros e suspensões temporais que os conectam, criando para este corpo uma correspondência em limiar do presente e do passado. Como discutido no primeiro capítulo, o corpo ideologicamente nomeado "pós-moderno", longe de ser um “corpo novo" cuja história foi apagada, figuraria como o sujeito moderno em ruínas que pode ser entendido talvez como um sujeito "hipermoderno".

Nosso tempo conseguiu eliminar a escatologia revolucionária instaurando uma revolução permanente do cotidiano e do indivíduo: privatização ampliada, erosão das identidades sociais, desgaste ideológico e político, desestabilização acelerada das personalidades. Estamos vivendo uma segunda revolução individualista (LIPOVETSKY, 2005: 15).

Para Benjamin, é necessário estar atento em relação aos acontecimentos, "sem distinguir entre grandes e pequenos (...) na medida em que nada do que uma vez aconteceu pode ser dado como perdido para a história (BENJAMIN, 2012b: 10). Nossa melancolia seria um rastro tributário de uma cisão, construída desde a modernidade, sob a ideologia positivista da ordem e do progresso. A ânsia do melancólico é de, a partir dos rastros, desses "pequenos acontecimentos", índices de um ideário perdido, religar-se a uma unidade pública, congregando o discurso deste corpo "singular" a um discurso, de fato, político e partilhado.

Esta corporeidade melancólica, ao propor uma linguagem de 
rastros e de correspondências liminares, pressupõe a escuta das vozes massacradas e recalcadas de nosso corpo social, que, tais como as sucatas baudelairianas, dão-nos acesso a um processo de rememoração desta história soterrada:

(...) a distância temporal não é mais superada graças a uma experiência comum, mas através do elo precário do índice, tão precário quanto o fio de cabelo que leva o detetive ao autor do crime. A associação entre história e crime não é mera coincidência: são justamente os crimes do passado que devem ser recuperados pelo presente. (OTTE, 2012: 80)

Este corpo melancólico, tal qual a figura do detetive, busca perfazer e reescrever a história deste crime moderno, origem da mineralização ${ }^{67}$ de nossa experiência hipermoderna. Este processo baseia-se na assimilação dos rastros em negação de um discurso historicista e dramatúrgico linear, bem acabado e sem rupturas. Assim como a história e a escrita benjaminiana, os dispositivos de criação para um corpo melancólico (tais quais os vestígios de um crime), não emergem segundo uma lógica metodológica linear de causa e efeito, são antes rastros deixados ali e que se conectam a partir de índices tanto conscientes quanto inconscientes. Podemos dizer que os dispositivos de criação são "encontrados", "revelam-se" e operam também como

\footnotetext{
${ }^{67}$ Antonio Candido apoia sua análise literária do romance "Senhora", de José de Alencar, em um conceito fruto da modernização, similar ao que utilizo para descrever o corpo melancólico: "Vemos que o comportamento do protagonista exprime, em cada episódio, uma obsessão com o ato de compra a que se submeteu, e que as relações humanas se deterioram por causa dos motivos econômicos. A heroína, endurecida no desejo de vingança, possibilitada pela posse do dinheiro, inteiriça a alma como se fosse agente duma operação de esmagamento do outro por meio do capital, que o reduz a coisa possuída. E as próprias imagens do estilo manifestam a mineralização da personalidade, tocada pela desumanização capitalista, até que a dialética romântica do amor recupere a sua normalidade convencional." (CANDIDO, 2012: 6) (Grifo nosso)
} 
passagens entre os próprios estados melancólicos desse corpo.

Durante o processo de ensaio de Anatomia da Melancolia experiência I, eu me colocava no limiar da vigília e do adormecimento, dispunha-me ao limiar da consciência e da inconsciência. Muitas vezes uma memória involuntária evocava simultaneamente tanto imagens/rastros de sonho, quanto os gestos/rastros de minha avó, quanto gestos que advinham do estado de prostração e fúria de meu corpo, apontando intensões desordenadas e contraditórias de movimento e compondo um mapa dramatúrgico constelar. Tal mapa era baseado no choque dialético entre todos esses detritos de memória esquecidos e que foram encontrados - como as pistas de um crime - também no material teórico estudado. Essas imagens ou índices de minha história "particular" se tornavam gestos que chocavam entre si, configurando imagens dialéticas que, por sua vez, conectavam-se em uma dramaturgia caracterizada pela desordem: como uma constelação de rastros de memória em choque.

Com relação a essa recuperação da memória, por meio de rastros apagados, um trecho do volume I, de Em Busca do Tempo Perdido, de Marcel Proust ${ }^{68}$, pode ser bastante elucidativo. A articulação narrativa entre os rastros de memória reflete igualmente a estrutura de conexão entre os rastros de movimento da corporeidade melancólica experienciada:

Meu corpo, demasiadamente entorpecido para se mexer, procurava, a partir da forma de seu cansaço, a repetir a posição de seus membros para induzir a direção da parede, o lugar dos móveis, para

\footnotetext{
${ }^{68}$ Aqui vale citar o papel de Proust na obra de Benjamin. Nas palavras do pensador Gershom Scholem (2004: 16): “A obra de Proust designa em Benjamin aquele lugar no qual o mundo dos adultos e o mundo das crianças se entrecruzam entre si da maneira mais perfeita (...)." (Tradução nossa).
} 
reconstruir e para nomear a morada onde ele se encontrava. Sua memória, a memória de suas costelas, de seus joelhos, de seus ombros, lhe apresentavam sucessivamente inúmeros quartos onde ele havia dormido, enquanto ao seu redor as paredes invisíveis, mudando de lugar segundo a forma do cômodo imaginado, agitavam-se nas trevas. $\mathrm{E}$ antes mesmo que meu pensamento, que hesitava no limiar dos tempos e das formas, tivesse identificado a moradia aproximando as circunstâncias, ele, - meu corpo, - se lembrava para cada um, o tipo da cama, o lugar das portas, de onde davam as janelas, a existência de um corredor, com o pensamento que eu tinha ao adormecer e que eu reencontrava ao acordar. 69 (PROUST, 1988: 6) (Tradução nossa)

A partir da leitura que Benjamin faz sobre a obra de Proust, caberia à rememoração (em processo histórico e coletivo, similar à citação acima), a restituição do índice messiânico. Desse modo, podemos pensar que a ideia de redenção refere-se à possibilidade de se modificar o presente por meio da rememoração dos rastros da história.

Das correspondências e conexões entre esses rastros de memória e sonho, entre consciência individual e conteúdo historicamente sedimentado, é talvez possível recriar uma verdadeira imagem do passado, embora "a verdadeira imagem do passado passa por nós de forma fugidia. $\mathrm{O}$ passado só pode ser apreendido como imagem irrecuperável e subitamente iluminada no momento de seu

\footnotetext{
${ }^{69}$ No original: "Mon corps, trop engourdi pour remuer, cherchait, d'après la forme de sa fatigue, à repérer la position de ses membres pour en induire la direction du mur, la place de meubles, pour reconstruire et pour nommer la demeure où il se trouvait. Sa mémoire, la mémoire de ses côtes, de ses genoux, de ses épaules, lui présentait succesivement plusieurs des chambres où il avait dormi, tandis qu'autour de lui les murs invisibles, changeant de place selon la forme de la pièce imaginée, tourbillonnaient dans les ténèbres. Et avant même que ma pensée, qui hésitait au seuil des temps et des formes, eût identifié le logis en rapprochant les circonstances, lui, - mon corps, - se rappelait pour chacun le genre du lit, la place des portes, la prise de jour des fenêtres, l'existence d'un couloir, avec la pensée que j'avait en m'y endormant et que je retrouvais au réveil.".
} 
reconhecimento." (BENJAMIN, 2012b: 11).

Resistindo à total anulação de sua história particular e partilhada, este corpo melancólico - ele mesmo rastro esquecido de sua própria época - a partir de um trabalho com esses restos, com os ecos de sua experiência vencida (vendida) pelo progresso da mercadoria, move-se de modo a tentar recriar sua época, tendo como material de trabalho e discurso sua própria linguagem danificada, corporeidade composta por buracos e incompletudes.

Em Anatomia da Melancolia - experiência I, a contradição de um corpo que emerge de suas próprias cinzas, que ainda respira sob o pó, manifesta-se a partir de uma síncope entre um corpo mudo e paralisado que se move com esforço e resistência - e o corpo do discurso verbal, ancorado sobre dois pés e que discursa sobre um conceito de melancolia. O primeiro corpo (paralisado e mudo, que ocupa o plano baixo da cena) está em luta constante para se erguer, deformando-se a todo tempo em vista de adquirir uma forma, porém, no momento em que essa forma é alcançada, configurando um segundo corpo (sustentado sobre o apoio dos pés e que ocupa o plano alto), e que sua fala se desenvolve, em pouco tempo são as próprias palavras que começam a se desmanchar, fissurando a narrativa, criando lacunas no discurso. $\mathrm{O}$ sujeito verbal se congela, as palavras sofrem interrupções, ficam suspensas como rastros no ar. Essa suspensão designa um estado de cisão e fracionamento do corpo, refletindo o espaço do discurso do melancólico. A dramaturgia é construída por uma dialética entre a movimentação e a fala, entre um estado de paralisia e de furor, em resistência ao seu próprio esgotamento e dissolução.

Podemos dizer que essa linguagem danificada nasce de um trabalho de luto deste corpo em relação ao seu próprio cadáver social e 
histórico: um corpo que é a todo tempo atravessado por linhas contraditórias entre seu "eu particular" e seu "eu comum". Paradoxalmente, o melancólico não consegue completar seu luto, seu processo está sempre inacabado, repleto de rastros em choque que não encontram uma síntese possível: ao se contradizer, seus vetores acabam por se anular mutuamente, tornando a paralisá-lo. Sua corporeidade se caracteriza, assim, por uma dialética sem síntese (uma dialética da suspensão, como dirá Benjamin, ou uma dialética negativa, nas palavras de Adorno), pois, embora lide com as contradições em choque, essas permanecem suspensas em um verdadeiro estado de exceção, fazendo com que o luto não se complete. É justamente este "inacabamento", esta impossibilidade de completude entre suas tensões em choque que engendra a potência de sua corporeidade e que forja a dramaturgia de seus gestos, breve redenção: trata-se de uma linguagem de um estado de exceção, que revela a desordem, no limiar da memória voluntária e involuntária, da multiplicidade de vetores que movem este corpo e que não encontram uma harmonia pacificadora que supere sua angústia.

\section{RASTROS DA VIOLÊNCIA}

A voz deste corpo, linguagem de seu próprio vazio e cansaço esta fatigue de Proust - busca esboçar um encadeamento lógico para as ideias, mas essas se apresentam entrecortadas umas pelas outras; a fala está atravessada por silêncios, buracos, hiatos, suspensões no tempo, tal como o processo de rememoração empreendido pelo personagem de Proust. Gagnebin afirma que tal rememoração, em vez de repetir aquilo de que se lembra, "abre-se aos brancos, aos buracos, ao esquecido e ao 
recalcado, para dizer, com hesitações, solavancos, incompletudes, aquilo que ainda não teve direito nem à lembrança nem às palavras.”. A rememoração também significa, na leitura que Gagnebin faz de Proust, "uma atenção precisa ao presente, em particular a estas estranhas ressurgências do passado no presente (...). A fidelidade ao passado, não sendo um fim em si, visa a transformação do presente." (GAGNEBIN, 2009: 55)

Em Anatomia da Melancolia - experiência I, as ideias estão dispersas no espaço, assim como os membros deste corpo: a ordem anterior, a de "uma anatomia moderna" está cheia de vazios, de buracos que o olhar melancólico revela a partir de uma ação de dissecação do corpo presente. A ordem social dominante, bem como sua própria ordem anatômica estão, para esse corpo, destituídas de sentido. Esse corpo sente-se apartado da antiga ordem moderna, daquele cogito e busca a transformação de sua anatomia a partir desses fragmentos de palavras e rastros de memória. Cada membro poderia ser lido como uma estrela destacada de uma constelação, cujas linhas de conexão (para que possamos dar forma a esta constelação) devem ser traçadas pela imaginação daquele que contempla, em nosso caso, do espectador.

Este deslocamento de uma ordem temporal se faz visível ainda em um deslocamento espacial: a propriocepção deste corpo está afetada, o melancólico vê seu corpo amputado, seus membros estão deslocados de seu lugar original, de sua posição habitual. De acordo com sua autopercepção, seu mapa anatômico foi destituído de sua ordem primordial, sendo esta auto-percepção uma ressonância e assimilação de seu próprio contexto social. A partir desta imagem interna, desta constelação corporal composta por imagens contraditórias em suspensão, nasce um dispositivo que denominei amputação das partes. Este corpo está "ausente", sente 
seus membros como membros "fantasmas", como "montes de massa imprestáveis e esquecidos", como se olhasse para suas mãos e dissesse "Elas não pertencem a mim!". "Elas estão fora de lugar, encontram-se deslocadas, amputadas" 70 : são rastros daquilo que em algum momento foi um corpo humano moderno (essa constelação primeva) e que agora procuram constelar-se em outra anatomia física e social.

A ausência necessariamente substitui algo que em algum momento do passado existiu. Esta falta - "membro amputado" presentifica um passado e nos faz lembrar que um dia, existiu. Um membro ausente seria assim um membro que, embora "fisicamente presente" neste corpo, em sua propriocepção histórica e social não está ali, trata-se de uma "falsa" presença, pois perdeu sua cognoscibilidade que o ligaria a uma história social partilhada. Podemos dizer que esse corpo está marcado por uma demissão subjetiva pois foi expropriado de seu sentido histórico. Quando falo desta forma humana que não se pode mais reconhecer, falo da demissão de uma espécie de "anatomia subjetiva”, para a qual a demissão de seus membros é a demissão de uma corporeidade anterior, que foi substituída por uma outra cujos membros se encontram desordenados e espalhados, "fora de lugar", como rastros de uma anatomia esquecida sob os escombros de nosso cotidiano contemporâneo, esse igualmente amputado de sentido, de forma.

O trabalho deste nosso corpo melancólico se funda em uma investigação a partir da percepção desta ausência, desta espécie de "amputação" proprioceptiva de seus membros e de sua história. A ideia matriz para esta corporeidade é deixar emergir suas amputações históricas, tomando como ponto de partida a própria negação do corpo,

\footnotetext{
${ }^{70}$ Trecho do caderno de direção dos ensaios de Anatomia da Melancolia - Experiência $I$.
} 
sua ausência proprioceptiva. Eu diria que se trata de uma corporeidade da ausência, composta dos próprios rastros de seu processo de destruição e esvaziamento: ao mover-se, ao deslocar-se, esse corpo busca as correspondências entre os rastros que se encontram espalhados, soterrados e esquecidos em seu contexto histórico e que poderiam recolocá-lo em uma história autêntica, reconferindo-lhe uma linguagem a partir da própria ausência.

Assim como Baudelaire "entreviu espaços vazios nos quais inseriu sua poesia" (BENJAMIN, 2000: 110), a ausência neste corpo melancólico se materializa, dialeticamente, a partir do que podemos perceber como rastros desse corpo, fantasmas de seus membros, daquilo que em algum momento no passado ou mesmo no porvir poderia constituir uma ordem para esse corpo ausente, compreendendo que a desordem de seus rastros anatômicos são, igualmente, rastros da história de uma coletividade.

A desordem deste corpo testemunha uma desordem social (escondida no nosso cotidiano), que carrega em si uma grande dose de violência, característica dos crimes históricos dos quais falamos anteriormente. $\mathrm{O}$ vazio melancólico do indivíduo hipermoderno testemunha esse abuso e essa violência que produzem um abatimento coletivo, daí, por exemplo, o incessante despencar do corpo, o inacabamento dos movimentos, a insustentabilidade de um eixo vertical em Anatomia da Melancolia - experiência I. Esse corpo não consegue resistir à gravidade (gravidade também social), evidenciando a desordem de uma época trágica, na qual nossa narrativa histórica se repete como um eterno presente, em um ininterrupto despencar, como um corpo sem passado e sem futuro, suspenso, sem memória e sem história, um corpo 
que vive um cotidiano de violenta harmonia, sob pílulas de pseudoapaziguamento de sua angústia:

A nova ideologia se apropria dos fatos da desordem e cancela o sofrimento no momento em que encontra o nome de um período ou fase. Da noite para o dia podemos transformar tudo em passado, porque acreditamos no futuro. $\mathrm{O}$ nosso presente verdadeiro, no qual a desordem é radical, está tão eficazmente escondido (...). (WILLIAMS, 2002: 90)

Embora tributário do esquecimento, este corpo está fundado sobre a "desordem radical" que o presentifica, que o coloca em deslocamento, movido pela inquietação de encontrar seu objeto perdido: perdeu a potência de uma corporeidade que conjugue uma subjetividade particular à partilhada. Este objeto perdido não se encontra no passado (como no caso do luto), nem no futuro, mas em uma temporalidade messiânica ${ }^{71}$. O objeto perdido da melancolia deve ser entendido como a própria linguagem e como o próprio tempo que lhe falta; sua corporeidade se funda no limiar do indivíduo e da coletividade, como vimos, elo rompido por nosso trauma civilizatório ocidental. Este corpo melancólico deseja trazer à tona seu trauma e as forças históricas que o geraram: a todo tempo ele parece atestar a cisão do sujeito e sua fragilidade em relação à ordem do mundo (em sua completa desordem, deve-se dizer), revelando

\footnotetext{
${ }^{71}$ O tempo messiânico "é o tempo que o tempo nos dá para acabar - ou mais exatamente o tempo que empregamos para realizar a conclusão, para completar nossa representação do tempo.". Este tempo messiânico, para Matos, "não é uma linha do tempo cronológico, nem o instante do fim (...); é o tempo operativo que urge no tempo cronológico, que o elabora desde o interior, tempo de que temos necessidade para concluir o tempo (...) é o tempo que resta." O tempo que resta não é um tempo suplementar, que se acrescenta ao tempo cronológico para adiar indefinidamente o nosso fim. "O tempo messiânico, sem coincidir jamais com o tempo cronológico e sem somar-se a ele, o apreende e o leva a seu cumprimento desde o interior." (MATOS, 2006: 420).
} 
sua inquietação e potência irruptiva contrária a esta mesma ordem, dando luz às lacunas e perversões de uma vida que já estaria morta e desprovida de valor. Trazendo à tona a desordem a partir de seus rastros, resiste à normatização do choque e afirma nosso estado da exceção (escondido sob o véu cotidiano de uma falsa ordem, de uma pseudo-felicidade, poderíamos dizer) e sobrevivendo, ele mesmo, em um estado de exceção: em desordem.

\section{IMAGEM DIALÉTICA}

Talvez tenhamos algumas pistas de trabalho, ainda a partir do conceito de rastro, se investigarmos as imagens dialéticas de Benjamin, já citadas anteriormente.

As imagens dialéticas operam como síncopes temporais do indivíduo e de sua voz coletiva, tal como o choque não harmônico da esgrima de Baudelaire e os sussurros de utopia das revoluções (vozes ideologicamente nomeadas, segundo a narrativa dos vencedores, como “as vozes dos fracassados"). Como, a partir dos rastros, desses membros amputados de um todo anatômico e espalhados por diferentes épocas em choque no presente, deixar emergir uma corporeidade que rompa com as conexões conhecidas entre os elementos, permitindo novas aproximações, ressonâncias e analogias? (BENJAMIN, 2013a: 35)

Os elementos das culturas passadas eram resgatados e redimidos em novas "constelações" que se conectavam com o presente enquanto "imagens dialéticas". Não é que o pretérito lance sua luz sobre o presente ou o presente sobre o passado, a imagem (dialética) é aquela na qual comparecem em uma 
constelação o pretérito com o presente (...). (BUCKMORSS , 2005: 22)

Para compreender melhor a imagem dialética, retomo brevemente a imagem do "anjo da história", já citada em nosso primeiro capítulo. Alegoria precisa, a ação desse "anjo" é a de retirar o presente contemporâneo de seu invólucro de harmonia, desta ideológica e ingênua felicidade que nos é a todo momento imposta. Esse anjo exerce uma visão negativa em relação ao seu presente; ele busca os rastros deixados pelo passado, permitindo que emerja do subterrâneo inaudito da história, a violência dos nossos dias no corpo, a partir de uma ação igualmente violenta:

E se essa violência divina fosse a intervenção selvagem deste anjo? Ao ver o amontoado de escombros que cresce em direção ao céu, esses destroços de injustiça, o anjo contra-ataca de vez em quando para reestabelecer o equilíbrio, vingando-se do impacto devastador do progresso. Não poderia toda a história da humanidade ser vista como uma normalização crescente da injustiça, trazendo consigo o sofrimento de milhões de seres humanos sem nome e sem rosto? Em algum lugar, (...) os erros são registrados, a tensão aumenta e torna-se cada vez mais insuportável, até o momento em que explode (...) uma cólera de retaliação devastadora. (ZIZEK, 2014: 142)

O "anjo da História" age em uma intervenção messiânica e violenta, como uma espécie de violência divina que abre espaço à oportunidade revolucionária para Benjamin, oportunidade que poderia figurar uma espécie de redenção da história. Esse anjo recolhe os rastros do passado e intervém para fazer justiça e vingar o presente em tensão com o passado. A imagem dialética pode ser vista nesta operação: ela emerge do tensionamento entre diversas forças históricas consteladas em 
uma mesma imagem ou mônada. Há um choque intrínseco à imagem dialética, choque que supõe a instauração de uma outra temporalidade, já que sua operação mesma rompe com a linearidade historicista. Nesta imagem contraditória, o presente histórico se fabrica do choque de rastros recolhidos de diferentes tempos. Tal como uma mônada, nossa corporeidade melancólica parece manifestar esta mesma violência construída a partir de vetores contraditórios que, por sua vez, deslocam este corpo no espaço, deixando emergir em si mesmo esta "cólera de retaliação devastadora"; estando o próprio corpo retaliado, ele mesmo devastado.

A ação deste anjo instaura a contradição entre presente, passado e futuro, apontando para uma temporalidade messiânica. Podemos entender que este outro sentido de tempo confere às ações humanas sua legitimidade, instaurando uma outra "ordem" temporal, não historicista. Esta outra ordem funda-se assim em uma espécie de "religar" messiânico: religar da ação/gesto de um corpo (indivíduo) ao seu valor de leitura, de sentido, de cognoscibilidade que referencia, portanto, um corpo "partilhado por uma comunidade humana", ou a tradição, para Benjamin. Esta "ligadura" organiza a dramaturgia de Anatomia da Melancolia - experiência I, baseada em um condensamento de tempos em um mesmo corpo que, nesse momento, ultrapassa seu estatuto de indivíduo, assimilando em si mesmo seu estranho familiar, a saber, seu sujeito histórico. Poderíamos dizer que esse tempo messiânico refere-se a um corpo comum, contido no próprio corpo "particular".

A intervenção violenta do "anjo" desmistifica a pretensa ideia de progresso da hipermodernidade, associada aos ideais contemporâneos de felicidade e liberdade. A ação do anjo da história é uma pulsão violenta, pulsão intrínseca à imagem dialética de Benjamin, na qual o presente e o 
passado estão "telescopados". A imagem do telescópio em Benjamin é bastante esclarecedora, pois, por um lado, remete-nos ao esfacelamento da cultura, sua fragmentação, e por outro, constela seus rastros em uma única, porém heterogênea e conflituosa, imagem ${ }^{72}$. Não significa que o passado "explique" o presente ou vice-versa, mas que eles se encontram suspensos em uma espécie de síncope temporal irruptiva. O telescópio agregaria as duas tarefas do historiador (contra a ideia de progressão linear do historicismo): recolher os rastros da história e, ao mesmo tempo, sintetizá-los em uma imagem sincopada, plena de irrupções violentas que revelam as contradições dialéticas - e sem síntese ou redenção - da complexa experiência social do indivíduo hipermoderno.

É deste instante violento e apocalíptico que irrompe a imagem dialética; deste choque entre os rastros do passado no presente. Esta violência constitui um dos traços de nossa corporeidade melancólica: forças contrárias aparecem tensionadas na própria constelação anatômica e física, como tensões simultâneas em choque. É do conflito destas tensões contraditórias presentes no próprio corpo que surge a imagem dialética, na qual o presente pode ser captado no limiar com o passado, em um instante que, para Benjamin, seria uma oportunidade revolucionária: uma imagem suspensa, "fora do tempo": "a imagem dialética é uma imagem crítica, pois constitui-se como a interpenetração crítica do passado e do presente, sintoma da memória coletiva e inconsciente." (CANTINHO, 2008: 3).

\footnotetext{
72 "Benjamin propõe uma ideia de tempo descontínuo, em que o passado obscurecido pode irromper no agora como reminiscência fulgurante, desfazendo o encadeamento que sustenta as representações habituais. Essa irrupção adquire uma tonalidade explosiva, uma qualidade de choque, trazendo a violência e o traumático que os discursos dos vencedores recalcam, a "barbárie que os monumentos da civilização ocultam."” (QUILICI, 2015: 34).
} 
É deste instante criado pela imagem dialética, do Agora (Jetzeit), que o Outrora $^{73}$ emerge, composto daqueles sussurros que com dificuldade se fazem escutar, tais como as sombras de nosso presente atual. Podemos entender esse Agora como a própria imagem cênica que, tal como uma imagem dialética, religa a história pregressa deste corpo/macrocosmo melancólico ao seu presente histórico, bem como à imaginação sobre o futuro. $\mathrm{O}$ aspecto propriamente dialético dessa visão emerge no choque de tempos da imagem, que "libera todas as modalidades do tempo mesmo, desde a experiência reminiscente até os fogos artificiais do desejo, desde o salto da origem até a decadência das coisas. (...) $\mathrm{Na}$ imagem se condensam também todos os estratos da memória involuntária da humanidade.” (DIDI-HUBERMAN, 2011: 173).

Assim, este Agora emerge tal como uma constelação de tensões históricas que atravessam o corpo melancólico, conferindo a este sua própria linguagem:

Não se pode dizer que o passado esclareça o presente ou que o presente esclareça o passado. Uma imagem, ao contrário, é aquela em que o Outrora encontra o Agora em um raio para formar uma constelação. Em outros termos, a imagem é a dialética em suspensão. Pois, enquanto a relação do presente com o passado é puramente temporal, contínua, a relação do Outrora com o Agora presente é dialético: não é algo que se desenrola em sequência, mas é uma imagem que se faz de interrupções. Apenas as imagens dialéticas são imagens autênticas (ou seja, não arcaicas); e o lugar

73 “(...) A imagem é a dialética da suspensão. Pois, enquanto a relação do presente ao passado é puramente temporal, a relação do Outrora com o Agora é dialética: ela não é de natureza temporal, mas de natureza figurativa (bildlich). Apenas as imagens dialéticas são imagens autenticamente históricas, ou seja não arcaicas. A imagem que é lida - quero dizer a imagem no Agora do reconhecimento - suporta no mais alto grau a marca do momento crítico, de risco, que está no fundo de toda leitura. [N 3, 1]." (BENJAMIN, 1990: 479-480). 
onde as encontramos é a linguagem [N $\mathrm{N}$ 2a 3$]$

(BENJAMIN, 1989: 478-479) (Tradução nossa)

Rompendo com o fluxo ininterrupto da história, esta corporeidade, tal como uma constelação de imagens dialéticas, opera a partir de paragens, paralisias, suspensões - do movimento, da palavra instaurando um tempo messiânico, que poderia ser entendido como um tempo do devir. Vale notar que na visão da Kabbala (uma das fontes do pensamento e da articulação das ideias de Benjamin) a origem da palavra Deus é o peut-être (em francês: talvez) ou ainda, o peut être (em francês: pode ser). Assim, Deus, que poderia estar relacionado a este tempo messiânico, é aquele que se refere a um devir, a uma potência de ser, portanto, a algo que está no limiar entre o existente e o não existente, ao que pode ser (peut être). Daí a implicância do corpo, posto que esta operação de "poder ser", depende de nossas ações no mundo, Deus não está "dado", está em devir. Acompanhemos aqui:

Deus não é para ser confirmado ou não confirmado, pois aquele que diz que Deus existe com certeza se enclausura em uma ideologia, e aquele que diz que Deus não existe se enclausura em outra ideologia. Deus é um "talvez" [peut-être], uma abertura do espírito [l'esprit] (lembremos que, em francês, "l'esprit" significa, igualmente, espírito e pensamento). Mas esse "talvez" [peut-être], pode ser entendido, em francês, não apenas como "talvez", mas também como "pode ser" [peut être]. Isso quer dizer que seu ser não é da ordem da afirmação, mas de um poder ser. Entre "ser" [être] e "talvez" [peut être], se desenvolve toda uma aventura da dúvida. (OUAKNIN, 2010: 14) (Tradução nossa)

Esta corporeidade melancólica coloca o "presente" contemporâneo em perspectiva, constelando seu passado à imaginação 
(esta capaz de rememorar o passado e projetar o futuro): diferentes temporalidades se colocam em choque neste instante, em um tempo do Agora, em uma dialética em suspensão, como nos diz Benjamin ou, ainda, em uma dialética sem síntese, suspensa no limiar de tensões contraditórias em choque; dialética que não se completa, tal como os gestos em Anatomia da Melancolia - experiência I que não encontram fim, que não se completa.

As tensões e de linhas de força contidas em uma imagem dialética se manifestam na própria fisicalidade do movimento, em um limiar que conecta duas ações concomitantes, as quais denominei "ceder" e "resistir". Tomando o caso de Anatomia da Melancolia - experiência I, o corpo cede seu peso à gravidade da Terra e - contraditória e simultaneamente - resiste a esta gravidade, opondo a força de um de seus membros "amputados"/fantasmas contra o chão, por exemplo. Os choques operados pelas linhas contraditórias de força que atravessam este corpo melancólico podem ser vistas como a metonímia dos próprios conflitos históricos e sociais de nossa época. Este corpo vai, assim, ao extremo dos conflitos em sua fisicalidade mesma (tensões, distensões, oposições, trações), até que, do extremo das tensões, das contradições hiperbólicas que suspendem e paralisam este corpo, um deslocamento seja gerado.

Este deslocamento descreve uma linguagem que acaba por substituir a própria realidade, adquire sentido - autenticidade - porque passa a participar de uma história comum: esta corporeidade melancólica deseja revelar em si as tensões, linhas de força e choques soterrados de nossa anatomia social. A intensidade das tensões impressas no próprio corpo substituem e refletem a intensidade das tensões intrínsecas às relações sociais de nossa época. Não se trata, todavia, de compreender 
essa corporeidade como "representação" de seu contexto social, mas como expressão, para usar as palavras de Benjamin $^{74}$ : trata-se de entender esse corpo como sendo, ele mesmo, um contexto. É ele um traço histórico de sua época, um corpo que abriga em sua subjetividade anatômica, as contradições de determinada época. Um corpo que "participa", que partilha em sua corporeidade mesma, de uma história comum que, nele, se vê revelada: história/dramaturgia suspensa, não harmoniosa, mas em movimento, em choque dialético.

Para Benjamin, esta suspensão do tempo gerada pela imagem dialética corresponde a um instante revolucionário que deve ser captado pelo historiador (pelo próprio leitor, comum, da obra): este instante seria como uma constelação que emerge dos conflitos de uma realidade social, expressos nos choques dialéticos operados nas tensões e afetos desta corporeidade melancólica. Tal como "a beleza" para Baudelaire, ou a felicidade para Saint-Juste, essa corporeidade não consiste em uma parcimônia harmônica, mas eclode de um tour de force, de um instante criado pela saturação das tensões da linguagem e das relações históricopolíticas. É neste instante que sua linguagem adquire uma espécie de verdade - legitimidade e autenticidade histórica -, a partir da qual é possível "reler" com novos olhos seu contexto cultural de origem:

\footnotetext{
74 "Sobre a doutrina da superestrutura ideológica. Parece, à primeira vista, que Marx queria estabelecer aqui apenas uma relação causal entre superestrutura e infraestrutura. Mas já a observação de que ideologias da superestrutura refletem falsa e insidiosamente condições reais vai para além disso. A questão, na verdade, é a seguinte: se a infraestrutura de certa maneira (nos materiais de pensamento e experiência) determina a superestrutura, mas se tal determinação não é redutível à simples reflexão, então como totalmente à parte de qualquer questão a respeito da causa originária deve ser caracterizada? Como sua expressão. A superestrutura é a expressão da infraestrutura. As condições econômicas sob as quais a sociedade existe são expressas na superestrutura precisamente como, no caso do adormecido, um estômago cheio demais encontra não o seu reflexo mas a sua expressão no conteúdo dos sonhos, os quais, de um ponto de vista causal, podemos dizer que "condiciona". A coletividade, desde logo, expressa as condições de sua vida. Essas encontram sua expressão no sonho e sua interpretação no despertar. (BENJAMIN, 2006: 392)
} 
A tarefa do historiador revolucionário da cultura consistia em perceber esta constelação instantânea e capturá-la em uma imagem verbal (...). "Do pensar faz parte não apenas o movimento dos pensamentos, mas também sua paragem. Quando o pensar se suspende subitamente, numa constelação carregada de tensões, provoca nela um choque através do qual ela cristaliza e se transforma numa mônada." Como não havia nada de logicamente necessário no progresso cultural, a percepção de "imagens dialéticas" era uma revelação que sempre aparecia como um choque de surpresa. (BUCK-MORSS, 2005: 22)

É este momento de cristalização - devido à intensidade das tensões - que deve ser visto como "chance revolucionária", para Benjamin. Essas "chances" são como pequenas estrelas que emergem das tensões criadas nas imagens dialéticas, dos choques implícitos à constelação entre passado e presente. Este corpo melancólico parece capaz de constelar em si, em sua linguagem própria, os conflitos e tensões histórico-sociais de seu contexto. Segundo Susan Buck-Morss, “a decisão de Benjamin de apresentar as ideias como imagens dialéticas antes que como conceitos, não era nem estética nem arbitrária mas sim claramente política." (Ibidem: 26).

Nosso corpo hipermoderno pode ser visto como o próprio rastro da barbárie, do estrangulamento da experiência em um mundo do espetáculo figurado em um presente contínuo, efêmero e fetichizado, onde os sussurros dos mortos parecem sepultados. Se de um lado este corpo melancólico - pós-traumático e emudecido - ressente a ausência deste instante revolucionário, de outro, parece escutar as vozes oprimidas e coletivas se aproximarem. A violência divina de um anjo interventor se faz ouvir aos ouvidos do melancólico. 
Ao nos voltarmos para Anatomia da Melancolia - experiência I, é possível identificar que esta corporeidade melancólica instauraria assim uma relação carnal e concreta com a realidade, presentificando em si as linhas de força de sua época, na tentativa de ensaiar - de experimentar em seus fluxos energéticos, deslocamentos e rupturas - um trabalho de luto sobre o cadáver (ainda sobrevivente) de sua história. Este corpo surge assim em experiência autêntica com sua realidade histórica, mobilizando uma corporeidade que carrega em si mesma seu objeto perdido: a dramaturgia de uma história comum. Estando este objeto recalcado e invisível, o trabalho com as imagens dialéticas é, neste solo de dança, um dispositivo para a eclosão das tensões, graças às quais, os rastros soterrados e esquecidos de uma história partilhada podem emergir. Em sua condição histórico-social, este corpo que dança lida com as contradições em uma tentativa de superação de seu próprio estado de exceção. Em uma relação visceral e direta com seu contexto, o melancólico se coloca em combate, estranha esgrima entre a vida e a morte do próprio corpo e da realidade, visto que, enquanto imagem dialética, corpo e contexto não se apresentariam mais cindidos, mas em fusão - não harmônica - de contradições:

O sol

Pois ao longo da viela em que, pelas mansardas, Persianas fazem véu às luxúrias bastardas, Quando o sol reverbera, imponente e inimigo, Sobre a cidade e o campo e sobre o teto e o trigo, Eu ponho-me a treinar em minha estranha esgrima, Farejando por tudo os acasos da rima, Numa frase a tombar como diante de obstáculos, Ou topando algum verso há muito em nossos cálculos.

(BAUDELAIRE, 1997: 176) 
A linguagem que advém da imagem dialética estabelece uma relação contraditória com seu objeto de abatimento, tal como o poeta esgrima suas rimas contra o mundo que quer compreender. Trata-se, em Anatomia da Melancolia- experiência I, de uma corporeidade da experiência e do choque e não da manifestação de um suposto sujeito que "domina", "conhece", que tem "controle" sobre a realidade ou sobre seu próprio corpo, mas que cria um Outro, outra corporeidade a partir da anulação de si e de seu contexto histórico-social, criando, das fissuras e inacabamentos de sua experiência, a possibilidade de uma oportunidade revolucionária:

A utopia aparece, aqui, no seu duplo modelo; se, por um lado, ela reveste um carácter teológico, reveste-se também de um carácter político, no quadro da justiça. Nunca será desajustado justapor messianismo e revolução no pensamento benjaminiano, pois o modo como a utopia surge no coração do presente é sempre sob a forma de "imagem dialética", que estabelece a fissura e o corte no tecido homogêneo da história, instaurando radicalmente o "instante messiânico", resgatando, à luz do presente, o passado, configurando-o numa outra ordem histórica: a da constelação de imagens. (CANTINHO, 2011: 177195).

Poderíamos dizer, em suma, que esta corporeidade se faz de tensões e contradições que podem ser vistas como a legitimação dos rastros de nosso corpo histórico social esquecido, que são reelaborados no presente deste corpo. Uma ação melancólica a partir das imagens dialéticas seria uma ação negativa - a contrapelo - em relação ao seu contexto histórico. Este parece ser o desafio desse corpo melancólico, sujeito propulsor de uma eclosão violenta do trauma de sua época. A 
experiência sepultada de nosso corpo hipermoderno, testemunhada em Anatomia da Melancolia - Experiência I, revela-se a partir de seus rastros que são fugidiamente encontrados neste corpo melancólico: "Aparecendo em fragmentos e em lugares esquecidos, a verdade falava apenas através de sussurros, Benjamin chamou a isto 'estar à escuta da tradição'." (BUCK-MORSS, 2005: 23). Nossa tarefa dramatúrgica foi trazer à superfície esses rastros.

$\mathrm{O}$ instante que pode ser deflagrado em um corpo que eclode da constelação de tensões contidas em uma imagem dialética, revela a chance revolucionária que não pode ser perdida. É nesse instante que pode-se ouvir os sussurros do passado, assim como é a partir dos lapsos rastros - que o analista consegue, como um reflexo no espelho, devolver ao analisando uma imagem do passado esquecida e recalcada "verdade" ou "tradição", para Benjamin, reveladora e fundante de sua subjetividade. O leitor da obra é convidado a ver esse reflexo - tal qual um relâmpago que nasce da fissura, do lapso, do instante.

Tomando uma vez mais Anatomia da Melancolia - experiência I como exemplo, o corpo presentifica o passado a cada apresentação, revelando uma constelação de tensões da cena que apenas se completam a partir da leitura que o espectador, tal como o detetive que investiga um crime, está à escuta de suas pistas, dissecando a cena enquanto traça uma constelação de tensões dialéticas entre sua experiência particular e aquela que experimenta junto ao corpo partilhado do público. Neste momento de apreensão, a imagem dialética se revela no limiar, no lusco-fusco entre a obra e o espectador. A crítica histórica pode ser traçada a partir desta suspensão, desta ligação inacabada entre o passado da obra e o presente do espectador. A crítica emerge - ela também uma linguagem - como um 
cristal a cada apresentação, refeita e refletida por uma "constelação saturada de tensões".

É deste "tempo fora do tempo" que emerge uma imagem dialética, do aparente deserto cheio de rastros em choque que o pensamento histórico e crítico parece se articular. Em Anatomia da Melancolia - experiência I, o espaço do espectador está previsto na própria obra, supondo em sua linguagem uma fissura de onde emergiria a ação crítico-histórica do leitor. As palavras enunciadas estão incompletas, inacabadas, a sintaxe está anulada, não há articulação lógica entre as frases pronunciadas, há uma dificuldade de verticalização do corpo; todos os elementos ou condições modernas do discurso racional aparecem apenas fugidiamente, "não se sustentam" durante um longo tempo, são logo negadas pelo choque de outra força oposta: uma queda brusca em direção ao chão, ou ainda, um gesto que se inicia em outra direção (sem que o primeiro tenha se completado), permanecendo, ambos, inacabados e abrindo a oportunidade para um vazio que anseia não por sua completude, mas por uma elaboração e reflexão sobre a própria "qualidade" deste vazio. A horizontalidade e proximidade entre cena e público indicam ainda uma indistinção entre os valores do corpo do intérprete (indivíduo, "particular") e o corpo do comum (público), implicando em uma relação estética, também ela, no limiar do individual e partilhado.

Pensar essa corporeidade melancólica a partir da ideia de imagem dialética de Walter Benjamin, auxilia-nos a desnaturalizar o estado de exceção em que vivemos, retirando-o da falsa harmonia cotidiana para a qual o choque se tornou a norma, deixando irromper nesse e desse corpo um estado de espanto diante de sua realidade, estado de exceção tributário do progresso do capital e de sua consequente miséria e 
esquecimento dos corpos:

A tradição dos oprimidos ensina-nos que o estado de exceção em que vivemos é a regra. Temos de chegar a um conceito de história que corresponda a essa ideia. Só então se perfilará diante de nossos olhos, como nossa tarefa, a necessidade de provocar o verdadeiro estado de exceção; e assim nossa posição de luta contra o fascismo melhorará. (BENJAMIN, 2012b: 13).

A anatomia ansiada por esta corporeidade melancólica não procura preencher (em uma tentativa sempre fracassada) o vazio, mas fazê-lo falar a partir dos choques latentes de uma ordem social que também move este corpo. Não há harmonia nesta corporeidade, trata-se de uma constelação de fraturas e rastros que eclodem do combate entre as tensões presentes em uma imagem dialética. Há uma luta entre o corpo do indivíduo e o corpo público, combate também ele suspenso no limiar de fios sociais tensos e contraditórios: choque inaudito, mas latente no vazio instaurado entre indivíduo e corpo comum.

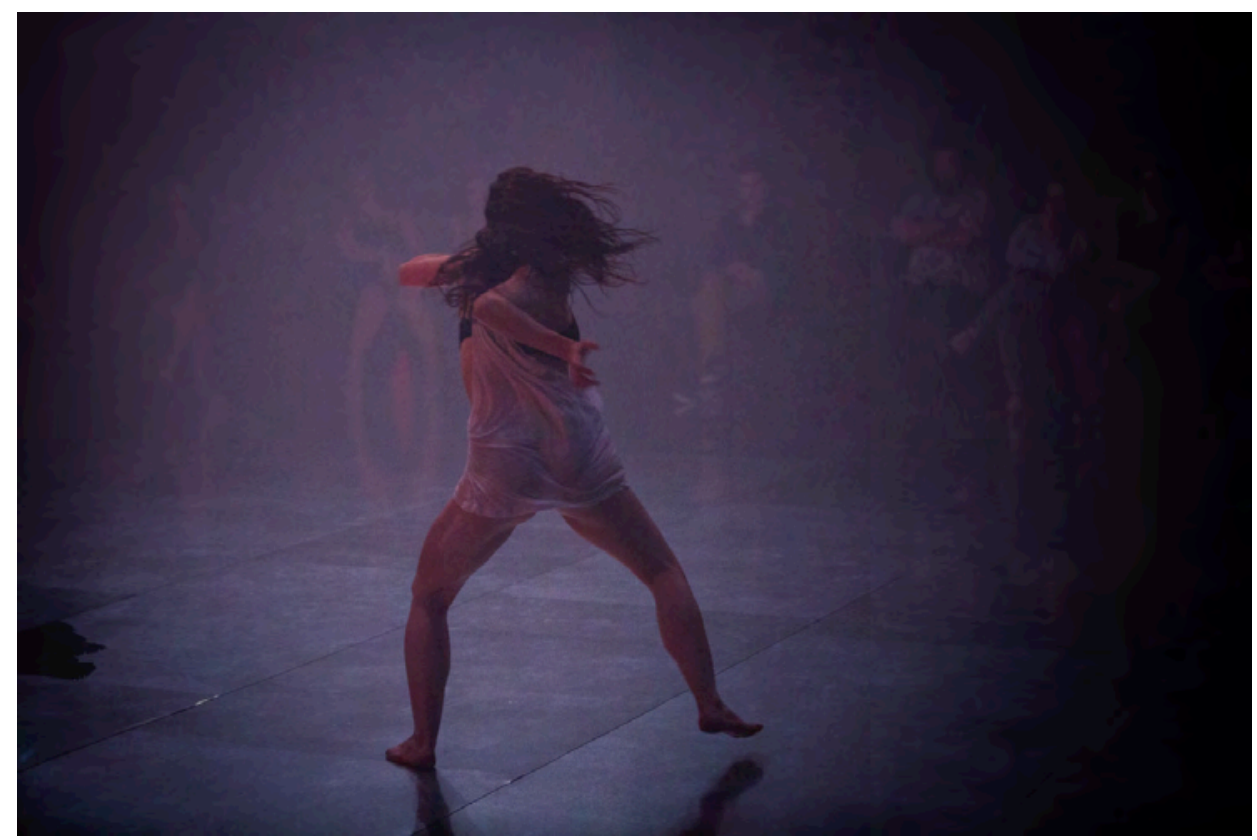

Imagem 3. FUROR - Anatomia da Melancolia - experiência I. 


\section{CAPÍTULO 3 \\ MNEMOSYNE SOBREVIVENTE}

Após a reflexão acerca da relação entre a melancolia e o processo histórico transcorrido a partir da modernidade, neste capítulo tentaremos esboçar como a experiência e linguagem de um corpo melancólico podem significar uma estratégia de resistência e sobrevivência do corpo em seu processo histórico: uma corporeidade motivada pela ideia de utopia $^{75}$ que, contraditoriamente, nasce da tragédia, da desordem e falência hipermoderna.

A expressão bastante elucidativa de Benjamin, aquela de "escovar a história a contrapelo", implica revelar uma síntese heterogênea e conflituosa dos tempos, evidenciando o choque dialético entre os rastros históricos e suas negações internas. Uma corporeidade que se faz a partir de choques dialéticos, entre diversas passagens históricas e dos movimentos do corpo, aproxima-se da ideia de montagem surrealista, que tanto inspirou Benjamin em seu Passagens, bem como a composição de Aby Warburg em seu Atlas Mnemosyne. O Atlas "desconstrói por sua própria exuberância, os ideais de unicidade, (...) de pureza, de

\footnotetext{
${ }^{75}$ Utilizamos aqui a definição de utopia tal como empregada pelos filósofos da chamada Escola de Frankfurt. Ernst Bloch sugere a poética definição de utopia como "um órgão metódico para o novo, estudo objetivo de agregação do ascendente.". Todas as grandes obras da cultura teriam, assim, ainda que nem sempre explícito, um pano de fundo utópico compreendido dessa maneira: "a função utópica arranca os assuntos da cultura humana do leito pútrido da mera contemplação e desse modo descortina sobre cumes de fato galgados o panorama ideologicamente desimpedido do conteúdo da esperança humana." (BLOCH, 2005: 152). Bloch refere-se àquilo que Benjamin chamou de profecias: "é a tarefa importante da história da arte decifrar, nas grandes obras do passado, as profecias em vigência na época de sua concepção." (BENJAMIN, 2013c: 131-132). Essa capacidade de imaginação de um futuro possível, presente na função utópica das obras artísticas foi bastante importante para os marxistas da chamada teoria crítica, geralmente identificados como membros da Escola de Frankfurt, durante todo o século XX.
} 
conhecimento integral. Ele é uma ferramenta, não a exaustão lógica das possibilidades dadas, mas da inesgotável abertura às possíveis ainda não dadas." (DIDI-HUBERMAN, 2011: 13). Na análise precisa de DidiHuberman, o princípio do Atlas de Warburg é a Imaginação: "A imaginação aceita o múltiplo. Não para resumir o mundo ou esquematizá-lo (...). O atlas é guiado por princípios móveis e provisórios (...) pois ler o mundo, é também religar as coisas do mundo.". Para religar as múltiplas estrelas isoladas, traçando novas constelações, seria preciso observar sua relações internas, suas correspondências. "As imagens não se apresentam apenas como cristais de 'legibilidade' histórica". Poderíamos dizer, nesta perspectiva, que "o atlas é uma máquina de leitura no sentido mais amplo que Benjamin quis dar ao conceito de Lesbarkeit." (Idem).

Historiador da arte que viveu entre 1866 e 1929, Aby Warburg materializa este processo de reconstrução palimpséstica da história supondo, em seu projeto Atlas Mnemosyne, uma leitura não linear: "Warburg gravou na entrada interna da famosa biblioteca de Hamburgo o nome de Mnemosyne, a personificação, na mitologia grega, da memória e o nome dado à mãe das nove musas." (SAMAIN, 2011: 34.). Mais do que uma qualificação, Mnemosyne representava, ao mesmo tempo, "uma organização sui generis do conhecimento e todo um programa intelectual.". Samain nos explica que "Warburg organizava, montava (não necessariamente numa ordem linear de leitura, mas à maneira de peças capazes de serem deslocadas a todo o momento) sobre painéis de madeira (de $1,5 \mathrm{~m} \times 2 \mathrm{~m}$ ), recobertos de tecido preto." (Ibidem: 36). O objetivo dessas verdadeiras instalações era fazer com que as imagens entrassem "em diálogo, se pensar entre si, no tempo e no espaço de uma longa história cultural ocidental; para que pudessem também ser 
observadas, relacionadas, confrontadas na grande arquitetura dos tempos e das memórias humanas." (Idem). Por meio dessas relações, físicas e espaciais, as imagens ganhavam corpo, "a história da arte tradicional transfigurava-se em uma antropologia do visual. (...) Deslocamentos e percursos não somente na temporalidade e na espacialidade das imagens, mas, ainda, nos tempos e nos espaços, nas margens, nos interlúdios e nos interstícios de uma grande história da arte.” (Ibidem: 40).

Os mapas de Warburg são feitos de rastros de diferentes momentos históricos, em choques dialéticos entre, si e que formam um "todo" ruidoso e fraturado. A imagem do Atlas pode ser utilizada para lermos a estrutura dramatúrgica da corporeidade melancólica de Anatomia da Melancolia - experiência I:

O que o atlas faz é, categoricamente, explodir os quadros. Ele macula as certezas autoproclamadas da ciência certa de suas verdades como também da arte sobre seus critérios. Ele inventa entre tudo isso zonas intersticiais de exploração, intervalos heurísticos. Ele ignora deliberadamente os axiomas definitivos. $\mathrm{O}$ que ele demonstra é uma teoria do conhecimento direcionada ao risco do sensível e de uma estética versada ao risco da disparidade. Ele desconstrói, por sua própria exuberância, os ideais de unidade, de especificidade, de pureza, de conhecimento integral. (DIDI-HUBERMAN, 2011: 13)

Tal como nas Passagens de Benjamin (1990), o Atlas agrega em uma mesma prancha imagens de "categorias" díspares: imagens astronômicas do Sol, da Lua e da constelação de escorpião aparecem ao lado de figuras de uma corte real, indicando, por esta montagem, um lapso de tempo e espaço entre as imagens, lacuna ou vazio que requer uma leitura heterogênea e a "contrapelo" da história, sendo preciso 
imaginar as "ligações íntimas e secretas entre as coisas, as correspondências e analogias." (DIDI-HUBERMAN, 2011: 32) entre esses contraditórios rastros, de diferentes tempos.

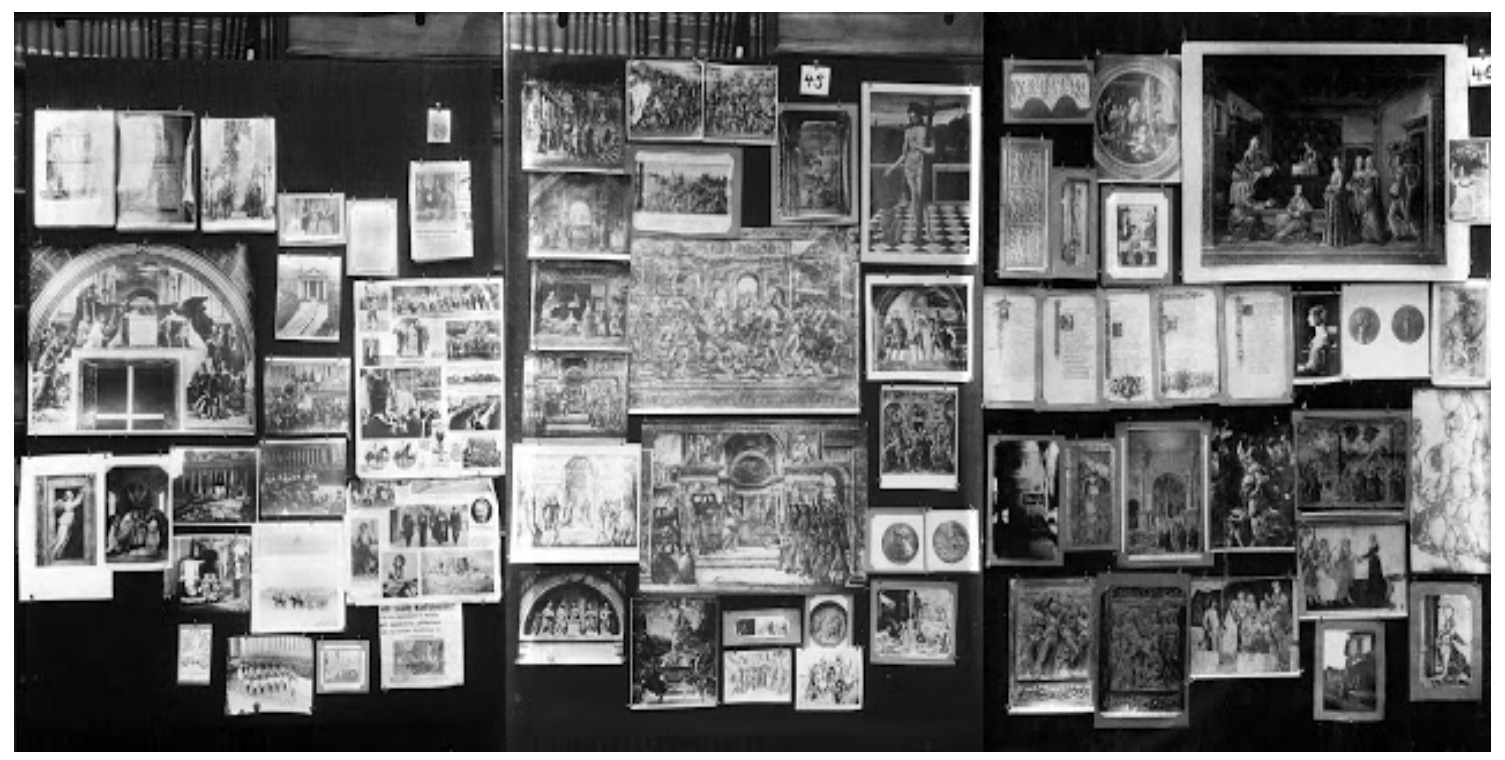

Imagem 4. Montagem que une três pranchas do Atlas Mnemosyne de Aby Warburg. (NIEL, 2011).

No início de seu processo de maturação (2013), Anatomia da Melancolia - experiência I, nasce de uma perna imprestável que não conseguia mais se mexer. Na primeira cena da obra (2015), minha boca tenta balbuciar algo logo que o público entra, mas assim que meus lábios se apertam, sou tomada por um cansaço hiperbólico, insuperável: embora os lábios se esforcem em se mover (bem como minha perna), estou emudecida, em trauma. A ordem do mundo antes reconhecível não me serve mais. Meu corpo está apagado, como um mapa anatômico em ruínas. Um corpo desarticulado que procura resistir à gravidade, ao mesmo tempo em que é tragado por sua tragédia. As solas dos pés e os próprios pés não me servem mais de apoio. Aliás, onde estão os pés? 
Antigamente eles estavam aqui embaixo, acabava a perna e começava o pé, mas onde estão as pernas? Meu corpo era como um rastro de um corpo histórico, social. Minha tíbia esburacada é o que governa o meu andar, mas é também o governo do andar de nosso sistema hipermoderno. Este corpo melancólico sou eu, mas é também o outro, é seu duplo social, é o particular mas é também um rastro de um corpo partilhado, pois cultural, pois econômico, pois político. "Meu" corpo é somente mais um rastro de um corpo melancólico comum, construído (ou descontruído) por um complexo e contraditório processo histórico. O trauma social é, portanto, experienciado como um trauma no próprio corpo do melancólico, pois seu "eu", este corpo, não está dissociado da história. É por este motivo que tomo o corpo melancólico como um corpo que existe no limiar entre o eu e o outro e as supostas fronteiras ideológicas que separam esse corpo de um contexto maior operam como uma violência contra este corpo.

Perfazer a anatomia da história, escavando seus estrondos e buracos, talvez seja um modo de retraçar uma anatomia do corpo, daí a inquietação - essa ânsia revolucionária - do corpo melancólico: o que havia antes, definições, fronteiras, balizas, mapas, nações, estão apagados, perderam o sentido, sendo necessário uma intensão revolucionária:

O que nos falta é uma percepção partilhada da situação. Sem essa ligatura, os gestos se apagam no nada e sem deixar vestígios, as vidas têm a textura de sonhos, e os levantes terminam nos livros escolares. (COMITÊ INVISÍVEL, 2016: 19)

Em negação de uma pretensa universalidade, trata-se de apreender os vestígios deixados pelo passado, ou seja, de se apropriar de seus 
rastros não em vista de uma unidade histórica, mas de uma trajetória formada por uma constelação de choques, carregada de contradições e lacunas históricas. Cada prancha do Atlas caracteriza-se por uma aparente desordem de imagens recolhidas e que supõem não uma narrativa histórica linear, mas uma leitura e trajetória forjadas nas passagens liminares dos rastros de diferentes épocas. Há um "vazio", uma lacuna proposital entre as diferentes imagens que compõe uma mesma prancha. Esse mesmo procedimento, este vazio proposital entre as cenas - uma espécie de "passagem suspensa" entre os quadros cênicos foi usado na composição de Anatomia da Melancolia - experiência I, sendo cada quadro/cena uma composição em choque entre imagens melancólicas recolhidas e operadas no corpo: "gestos da demência" de minha avó, juntamente com a imagem da Melancholia I, de Dürer, e das imagens que advinham dos enunciados contraditórios aos quais me submeti, tal como o que chamei de "furor e prostração", dinâmica característica do estado melancólico.

O procedimento esboçado acima pode ficar mais claro a partir desta passagem, vista na obra Atlas ou le Gai Savoir Inquiet, de Georges Didi-Huberman (2011: 11): “um atlas não é feito exatamente de 'páginas' no sentido habitual do termo: trata-se de quadros, de pranchas, onde estão dispostas as imagens.”. Estas pranchas são consultadas em vista de um objetivo preciso ou podem mesmo ser folheadas "livremente, deixando divagar nossa 'vontade de saber' de imagem em imagem e de prancha em prancha.". O passeio pelo Atlas não busca apenas informações, mas percorre "as bifurcações em todos os sentidos; só deixamos de recolher as pranchas após ter caminhado um certo tempo, erraticamente, sem intenção precisa, através de sua floresta, seu labirinto, 
seu tesouro. Esperando por uma próxima vez igualmente inútil ou fecunda." (Idem.) (Tradução nossa).

Segundo Warburg, na introdução que elaborou ao Atlas Mnemosyne, "Aquilo que chamamos de ato artístico não passa, portanto, de uma manipulação tátil do objeto para que ele possa ser espelhado de modo plástico ou pictórico. Esse ato artístico é equidistante tanto do modo típico da imaginação de colher os objetos quanto daquele característico da contemplação conceitual.” (WARBURG, 2011: 108). Warburg menciona uma intenção de fazer com que o corpo das imagens expresse o corpo coletivo que as origina: "Com seus materiais visíveis, o atlas Mnemosyne pretende justamente ilustrar esse processo que poderia ser definido como a tentativa de incorporar interiormente valores expressivos que existiam antes da finalidade de representar a vida em movimento (Ibidem: 109). A utilização do termo Mnemosyne justifica-se dessa forma: "Mnemosyne, com a sua base de material visual que o atlas anexado apresenta reproduzida, deseja sobretudo ser um inventário das pré-cunhagens de inspiração antiga que concorreram, no período renascentista, para a formação do estilo de representação da vida em movimento.". Vemos, assim, que as imagens, no atlas de Warburg, procuram constituir uma memória em movimento: "Trata-se de escala que abarca desde o desabamento absorto e inerte até a embriaguez homicida, mas também todas as ações mímicas que se encontram entre esses dois extremos." (Ibidem: 110).

A conexão entre as imagens do Atlas depende da imaginação do leitor, das passagens que esse cria entre as imagens, dado que a composição das pranchas não está orientada por qualquer critério cronológico ou geográfico. A trajetória dramatúrgica intrínseca a esta concepção requer uma atitude dialética do historiador que as observa, em 
nosso caso, do espectador da obra. O Atlas opera de modo constelar, em "vai e vem" no tempo: sua leitura se fabrica nos interstícios, nas suspensões, vazios entre as imagens em choque e que supõem a ação imaginativa de quem as observa: "É como se houvesse uma lei da História, uma linha de evolução histórica mais ou menos clara ou predominante, mas a revolução só pudesse ocorrer em seus interstícios, “contra a corrente.” (ZIZEK, 2009: 82). Esta postura parece absolutamente contrária à contemplação da história suposta como uma sequência de acontecimentos isolados e independentes do sujeito que a observa. Os rastros estão implicados, compõem a anatomia social deste corpo "particular" que dança.

O melancólico angustia-se diante do isolamento propagado pela sociedade liberal hipermoderna, não conseguindo se adequar à narrativa ideológica liberal, emudecendo, como os soldados que voltavam mudos dos campos de batalha à época de Benjamin, incapazes de narrar sua experiência. A manifestação deste corpo se dá aparentemente de forma exagerada, hiperbólica, como um desvio de linguagem que deflagra sua implicância em relação a uma miséria subjetiva social.

Contrariamente a uma impossibilidade absoluta da linguagem se, de um lado, esta corporeidade melancólica evidencia nosso trauma social - um corpo que se desloca em truncamentos, quedas, colapsos, destruição e desordem, corpo devastado que a todo tempo tenta inaugurar algo, uma fala ou um movimento e, de algum modo, é impedido de continuar - de outro lado, esse corpo sobrevive, resiste ao seu próprio fim, não se deixa sepultar. E é a partir desta sobrevivência que a oportunidade utópica parece emergir. Há uma ausência proposital de sustentação dos movimentos que são, milimetricamente, flutuantes, inacabados, embriagados, que despencam como as ruínas dos movimentos de nossa 
história e formação hipermodernas, revelando sua carga de destruição, porém, igualmente, a todo momento, esse mesmo corpo implode palavras e movimentos que procuram "um devir outro", busca uma anatomia "por vir". Não se trata, assim, de um corpo passivo diante de seu próprio massacre e esgotamento, mas de um corpo angustiado e inquieto que sobrevive graças à sua potência de contestação.

A trajetória de leitura proposta no Atlas é, assim, bastante próxima da experiência de história que nos interessa, tal como ensaiada por Benjamin ${ }^{76}$ : uma história segundo a qual o presente pode ser escutado como síntese inacabada, acúmulo e choque entre rastros do passado, em uma espécie de fraturas em constelação. O "presente" seria, portanto, um palimpsesto de muitas épocas que coexistem em um mesmo corpo - este nosso atlas anatômico - corpo que é ainda, ele mesmo, uma espécie de historiador. Em Anatomia da Melancolia - experiência I, uma constelação de traumas compõe esta corporeidade melancólica que supõe, assim como Warburg, uma dramaturgia de imagens dialéticas, formada de rastros de movimentos e palavras. Tal como no Atlas Mnemosyne, o "Agora” - Jetztzeit - em Anatomia da Melancolia experiência $I$, é constituído por uma constelação de inúmeras acontecimentos, traumas e afetos em choque, só possíveis de serem reconhecidos considerando-se a memória (rastros) deste corpo, ou seja, sua experiência histórica em determinado contexto: “A verdadeira

\footnotetext{
76 "O historicismo limitou-se a estabelecer um nexo causal entre os vários momentos da história. Mas um fato, por ser causa de outro, não se transforma por isso em fato histórico. Tornou-se nisso postumamente, em circunstâncias que podem estar a milênios de distância dele. O historiador que partir desta ideia desafia os acontecimentos pelos dedos como um rosário. Apreende a constelação em que sua própria época se insere, relacionando-se com uma época anterior. Com isso, ele fundamenta um conceito de presente como 'Agora' (Jetztzeit), um tempo no qual se incrustaram estilhaços do messiânico.” (BENJAMIN, 2013: 20).
} 
imagem do passado passa por nós de forma fugidia. O passado só pode ser apreendido como imagem irrecuperável e subitamente iluminada no momento de seu reconhecimento." (BENJAMIN, 2012b: 11).

Ao expor a "desordem" entre os quadros, o Atlas desvela nosso verdadeiro estado de exceção, permitindo que a história sobreviva sob uma outra ordem, caracterizada justamente pelo reconhecimento das imagens do passado, pela montagem dialética dos rastros e do choque ideologicamente soterrado. A imagem dialética traz, "pela polaridade e tensão que comporta, pela sua natureza interruptora, desconstrutiva e violenta, toda a possibilidade de acesso ao conhecimento da história e da temporalidade messiânica que nela se encontra (...)." (CANTINHO, 2008: 3). Para a autora, a operação da montagem implica em uma ação da imaginação: "a imaginação (...) que realiza a montagem, por excelência e não desfaz a continuidade das coisas senão para fazer surgir melhor as 'afinidades eletivas"”. Por meio desta leitura, Cantinho nos afirma que "Benjamin vê na imagem o modo de dar a ver o conteúdo histórico das coisas. (...) existe na imagem uma componente de violência, que antecipa a apresentação do conteúdo histórico.” (Idem).

A perda de uma experiência autêntica em nossa hipermodernidade corresponde a uma perda da capacidade imaginativa do corpo. Esta capacidade "perdida" figura como um dos elementos da repressão sofrida por este corpo melancólico. Em Anatomia da melancolia - experiência I, o corpo procura angustiadamente, a conexão entre as frases de movimento ou as frases que pronuncia, todavia, deparase com a própria impossibilidade e ausência sintática: um vazio substituiu as articulações entre as frases do corpo e as verbais, são as próprias conexões da linguagem falada e dançada que parecem ter desaparecido. Ora, são justamente as articulações da linguagem que 
trazem coerência e cognoscibilidade ao discurso de um corpo, que nos permite "comunicar" algo e legitimar nossa "fala", porém, essas mesmas articulações só existem mediante uma capacidade de rememoração e imaginação, faculdades capazes de conectar os rastros que este corpo com esforço traz à tona.

Nossa subjetividade hipermoderna fraturada ressente sua própria capacidade imaginativa atrofiada. Talvez seja do choque entre os corpos devastados de nossa sociedade do espetáculo (DÉBORD, 1993), conformada por imagens, informações que propagam o consumo, slogans, não-lugares, em que não há espaço para um autêntico processo de rememoração, que poderemos encontrar um outro sentido para nosso corpo histórico esquecido e, ainda, para a experiência do corpo com a história, com seu "Agora" - Jetztzeit - (BENJAMIN, 2013a). Anatomia da Melancolia - experiência I, estabelece-se como linguagem desviante, hiperbólica, em atitude de distanciar-se estando-se próximo, próximo do espetáculo, porém sem se confundir com ele. O corpo da cena manifesta um total esgotamento de ideais, exauridos por uma linguagem estética e política que não mais lhes expressa; para ele, sua linguagem mesma parece não mais responder às suas inquietações diante de uma vida danificada; corpo em luto diante de sua própria morte e que, no entanto, resiste.

Este corpo, em Anatomia da Melancolia - experiência I, parece sofrer a ausência de uma utopia, atestando nossa miséria: os "despencares" do corpo e da palavra relacionam-se a objetivos e ideários coletivos perdidos, irremediavelmente asfixiados pela deformação liberal hipermoderna, deformação que também se encontra nas próprias torções e oposições, a partir da luta e choque entre as linhas de forças engajadas no corpo. Entretanto, há irrupções que despontam como uma espécie de 
resistência ao nosso trágico estado de exceção, como breves formas que emergem do fundo de nossa miséria, como se anunciassem alguma possibilidade de redenção, porém tão logo se fazem, se desfazem, dado que não encontram contexto para que possam permanecer. Este corpo busca, a todo custo, uma trajetória histórica para si: sua inserção na história.

Essas imagens que resistem e que sobrevivem, sem que cheguem a um fim, instauram uma espécie de suspensão temporal sobre a desordem histórico-dramatúrgica, como uma emergência abrupta e violenta de afeto irrompendo de dentro da miséria liberal dos corpos de nossa história. O corpo é, diversas vezes, implodido por palavras que irrompem e que compõem uma dramaturgia fissurada por apineias asfixiantes, que vêm de um excesso de memória, de uma hiperbólica rememoração dos traumas e rastros e que, ao mesmo tempo, revelam uma ausência de sentido para esse amontado de imagens vividas, todavia não experienciadas.

Sobre a importância da ação da imaginação, valeria aqui relembrar a imagem do pintor Albrecht Dürer ${ }^{77}$, Melancholia I, cujo "I" do título da obra poderia se referir, segundo alguns estudos, à palavra em latim Imaginatio (Imaginação).

${ }^{77}$ Albrecht DÜRER; Alemanha (1471-1528). 


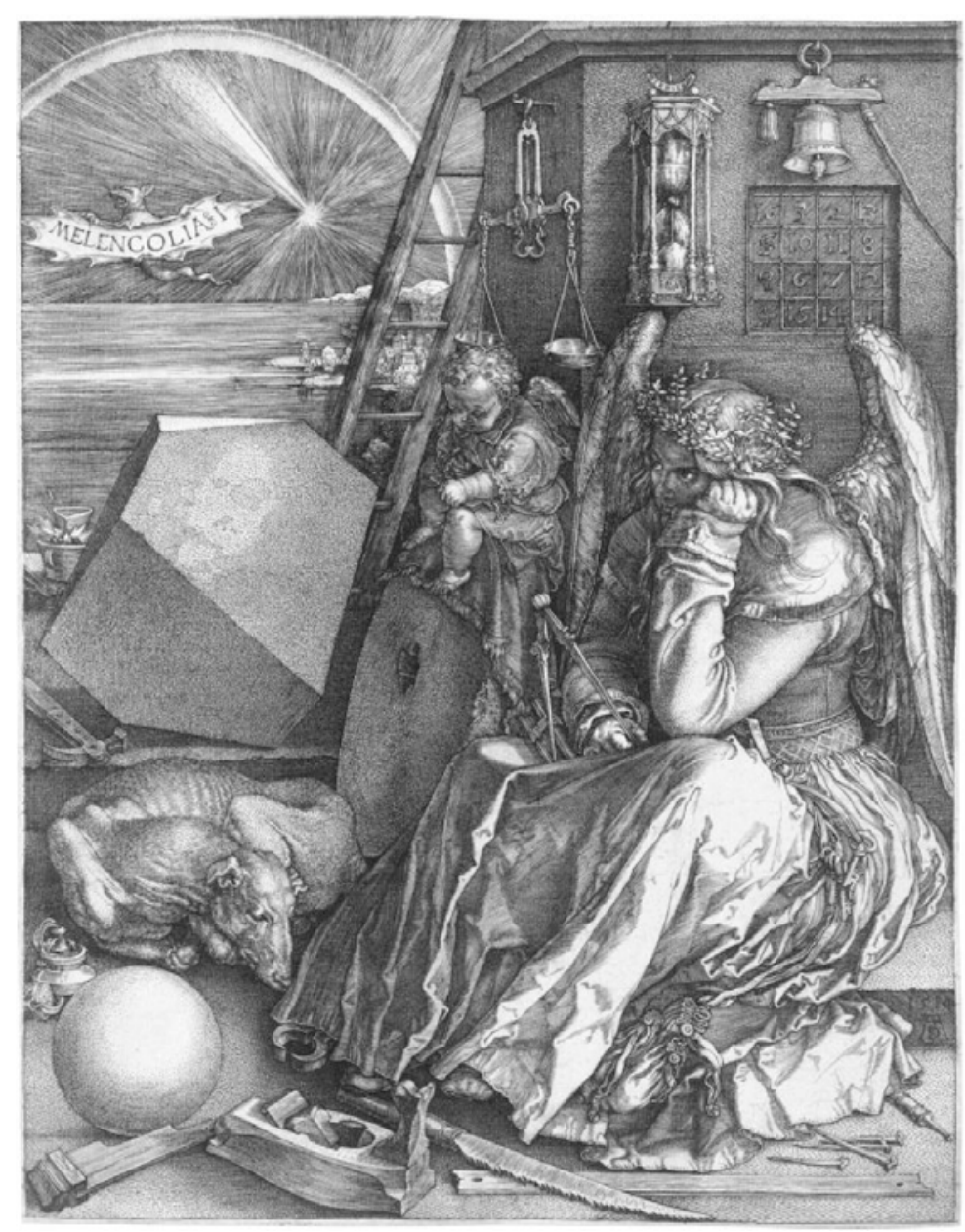

Imagem 5. Melancholia I. ALBRECHT DURER. (UN PHILOSOPHE, 2017)

Sobre a Melancholia I (1514) ${ }^{78}$ de Dürer, poderíamos dizer que a figura alada está em atitude passiva e contemplativa em relação aos objetos que a cercam. Contraditoriamente, é de sua capacidade

${ }^{78}$ Sobre a Melancholia I (1514) de Dürer, no capítulo "Opus Magnum - A Noite Saturnina", Alexander Roob (2001, p. 203) observa: "Os neoplatônicos florentinos consideravam a "bilis negra" do humor melancólico-saturnino como um estado de espírito propiciador de voos de fantasia do gênio e de um profundo conhecimento de si mesmo. O cadinho ou crisol na extremidade esquerda da imagem refere-se a um percurso cristológico de purificação, que, com a ajuda da trindade constituída pelo espírito mais sutil (Ikosaeder: quintescência), pelo corpo puro (cordeiro) e pela alma imaculada (esfera branca), conduz através da escada de sete degraus da sublimação até o êxito. O quadrado mágico por cima do anjo destina-se a concitar os poderes curativos de Júpiter". 
imaginativa - imaginação que advém também da contemplação e do tédio $^{79}$, como falamos em nosso primeiro capítulo - que poderia haver uma espécie de síntese heterogênea da história, criada a partir dos próprios objetos mundanos esvaziados de sentido que estão dispostos aos seus pés ${ }^{80}$. A acedia melancólica refere-se ao sentimento de um "mundo vazio" em que as ações humanas estão privadas de valor.

A alegoria de Dürer assume uma postura de negação dialética em relação ao mundo "externo": há uma distância patente entre figura e mundo ao redor. Tal como a alegoria do "anjo da história" de Benjamin, esta imagem de 1514 nos leva, uma vez mais, à ideia de uma leitura a contrapelo da história, baseada em uma espécie de lógica negativa e não linear, criada a partir dos interstícios históricos, dos limiares entre passado e presente. A imaginação no quadro de Dürer advém justamente deste vazio instaurado entre figura e mundo exterior: a imaginação da personagem parece nascer da ausência de correspondências entre seu corpo e os objetos ao seu redor. A própria inutilidade dos objetos do quadro, inutilidade que se refere a uma espécie de ausência de "verdade" dessas ferramentas, rastros de "medição da realidade" - compassos e números - parece abrir caminho para uma outra leitura da história: leitura a contrapelo, tecida a partir das "faltas" e não dos "feitos" históricos. Pode-se aqui fazer uma relação entre a figura melancólica de Dürer e o personagem Fausto, de Goethe, segundo Marshall Berman (2014: 55):

Surpreendemos Fausto cercado de belos e raros livros e manuscritos, pinturas e diagramas, instrumentos

\footnotetext{
${ }^{79}$ Cito aqui a imagem que Benjamin atribui ao tédio em seu ensaio "O Narrador": "o tédio é o pássaro onírico que choca os ovos da experiência." (BENJAMIN, 2012c: 221). Retomaremos esta citação em nossa Conclusão.

${ }^{80}$ Vale aqui nos debruçarmos sobre a análise da obra de Dürer feita por Benjamin em seu Origem do drama trágico alemão (BENJAMIN, 2013b: 155-159).
} 
científicos - toda a parafernália de uma vida espiritual bem-sucedida. No entanto, tudo quanto ele conseguiu soa vazio, tudo em volta dele parece um monte de sucata. Ele fala a si mesmo, sem cessar, e diz que nem sequer chegou a viver.

O corpo melancólico, de Anatomia da melancolia - experiência I, lida com este conflito sem solucioná-lo, mas contemplando-o. Tal como a figura de Dürer, que contempla uma diversidade de objetos que simbolizam "verdades matemáticas" esvaziadas de "utilidade", o corpo, em Anatomia da melancolia - experiência I, contempla seus próprios rastros - "verdades" - de memória que igualmente se apresentam esvaziados. É a partir de sua imaginação compulsiva e hiperbólica (manifesta na cinética de seus deslocamentos), que este corpo coloca em choque seus "rastros inúteis de memória" - seus "belos e raros livros e manuscritos" - com a esperança de que, a partir desta luta travada em sua corporeidade mesma, advenha algum sentido para sua história no mundo.

Seria preciso não apenas ler a história a contrapelo, mas fazê-la e narrá-la a contrapelo: "Precisamos da história, mas de maneira diferente da do ocioso mimado no jardim do saber" (NIETZSCHE, 2003: 32). Seria necessário reconstruir e imaginar a linguagem a partir de seus vazios melancólicos (não seria a melancolia uma linguagem?), de seus buracos esquecidos, de seus inacabamentos, de seus inúmeros rastros em choque e de onde surgem os sussurros de utopia, mnemosyne sobrevivente.

Em Anatomia da melancolia - experiência I, me propus criar, tal como as imagens dialéticas de Benjamin, uma linguagem não fusional, uma linguagem que se forma a partir de passagens, dos limiares de planos ou fragmentos que se justapõem uns aos outros em síncopes temporais, dado que a subjetividade deste corpo melancólico não se 
caracteriza pela linearidade narrativa, mas pela justaposição de seus estados, pela montagem mnemosyne entre fluxos energéticos e imagens rememoradas:

[a melancolia, em Benjamin] é o efeito e a causa de uma determinada sobreposição de imagens que perpassa, assumindo sempre novos traços e criando sempre novas correlações, sua obra. (LAGES, 2007: 104)

Anatomia da Melancolia - experiência I começa com uma paralisia generalizada do corpo e da fala; a gravidade parece superar a possibilidade desse corpo de se levantar. Um corpo em dissolução, mas que resiste a seu fim. Um corpo que ao tentar falar, falha. A articulação narrativa, antes familiar, parece agora inútil como linguagem. Sua função foi explorada, esgotada, exaurida; a ordem do mundo antes reconhecível não lhe serve mais e no lugar desta ordem subjetiva, a melancolia parece operar como uma qualidade de linguagem cuja marca é uma desordem radical das fronteiras. Os limites entre tecidos, ossos, órgãos, mente, líquidos, músculos, pele estão embaralhados, sem lugar definido: borrados em um mapa anatômico em ruínas. Em vez de fronteiras entre partes, ou entre o indivíduo e o outro, o corpo está organizado a partir dos limiares entre elas, assim como sua própria existência deve ser compreendida no limiar do individual, social e histórico. Não chega-se a uma síntese, mas parte-se desta, parte-se da síntese máxima do corpo que é a possibilidade de sua própria morte. A esta obra interessou evidenciar as contradições de um corpo social a partir de sua tragédia, em vista de seu renascimento utópico em outra ordem.

Este corpo buscou criar uma linguagem a partir das ruínas, dos próprios rastros do trauma; traduzindo os rastros de sua história em uma 
linguagem dramatúrgica que constela em si, simultaneamente, o sintoma desta doença social e seu antídoto ${ }^{81}$. O corpo se encontra prostrado, imóvel, e, de tempos em tempos, irrompe em furor tentando sair do lugar, buscando sua sobrevivência em um breve deslocamento, para logo retornar à imobilidade, repetindo o trauma até conseguir se erguer: o corpo passa por inúmeras tentativas de resistir à gravidade, buscando encontrar uma oposição possível para que consiga sair do chão. O buraco - o vazio - da tíbia esquerda ${ }^{82}$ é uma imagem metonímica de um esvaziamento e dilaceramento subjetivo: o corpo não pode se apoiar sobre o lado esquerdo, todo este lado é frágil e insustentável.

O corpo tenta resistir, embora revele uma enorme dificuldade para permanecer: o gesto e a fala estão marcados por inúmeras incompletudes e "falências" de linguagem; os movimentos dificilmente se completam; assim que um movimento inicia ele em breve se dissolve, como se o corpo não desse conta de sua própria partitura (e de fato, não seria possível dar), um corpo que mal se sustenta sobre os dois pés, como se até mesmo esta "ordem", a mera capacidade de se manter em pé, tivesse perdido o sentido. Trata-se de um corpo em perpétua melancolia

\footnotetext{
${ }^{81}$ Jaques Derrida, situado em espectro filosófico distinto do de Benjamin, no seu ensaio A farmácia de Platão (2005) menciona que Sócrates compara a uma droga os textos escritos que Fedro trouxe consigo, "esse phármakon, essa 'medicina', esse filtro, ao mesmo tempo remédio e veneno, já se introduz no corpo do discurso com toda ambivalência. Esse encanto, essa virtude de fascinação, essa potência de feitiço, podem ser - alternada ou simultaneamente - benéficas e maléficas." (DERRIDA, 2005: 14). A escrita é apresentada como um phármakon, veneno e remédio. O phármakon é um termo essencialmente ambíguo. Paradoxalmente, o phármakon é o signo que resiste à interpretação filosófica. Por um lado, não pode ser totalmente compreendido pela tradição, e por outro lado, a torna possível enquanto discurso metafísico. A escrita ou phármakon não tem essência estável nem se constitui numa substância, assim como também não é uma síntese dialética, simplesmente escapa a qualquer caracterização unificada. O phármakon oscila entre os termos em oposição: não é nem o remédio nem o veneno, nem o bem nem o mal, nem a fala nem a escrita. A melancolia pode ser vista, em nesta pesquisa, como uma espécie de phármakon.

${ }^{82}$ Falo a este respeito em Paisagem da Invisibilidade.
} 
diante de seu próprio fim, do fim de sua história de sua comunidade humana. O corpo aparece devastado, implodido e ao mesmo tempo irruptivo, detonante. O corpo e a fala estão assim decompostos em relação liminar com um contexto social também em desordem e decomposição radical, manifestando nosso estado de exceção que, no entanto, tornou-se norma.

Para Benjamin, é nas lacunas e fissuras (poderíamos dizer, do limiar) da linguagem melancólica e da realidade que reside a utopia das revoluções: o inacabado seria o objeto perdido, as vozes recalcadas dos "fracassados" que o sujeito melancólico procura escutar. Esta corporeidade melancólica constela em si os detritos deste corpo histórico inacabado: sua linguagem irrompe dos limiares e vazios dos conflitos históricos dissipados na realidade. Esta realidade pode ser vista tal qual uma das pranchas do Atlas Mnemosyne, de Warburg: inúmeros quadros "do real" nos são apresentados, massiva e diariamente, exigindo-nos assim um trabalho imaginativo - leitura da realidade a contrapelo - para que esse amontoado de imagens vazias dispostas ao nosso redor ganhe alguma coerência que não aquela do espetáculo fetichisante da mercadoria.

Uma corporeidade melancólica, ela também podendo ser compreendida como um atlas warburguiano, se faz do conflito entre os movimentos da memória (Mnemosyne), operando no limiar da paralisia e do furor contestatório, das atrofias musculares e espasmos hipertônicos ${ }^{83}$, supondo, nessa operação, os vazios conectivos entre todos esses elementos. As tensões e distensões deste corpo em Anatomia da

\footnotetext{
83 “(...) são os ventos que emprestam ao caráter melancólico sua inconstância (a predisposição a "sair de si'), sua predisposição a abatimentos profundos e ao furor, mas também sua rapidez de pensamento e sua criatividade.” (KHEL, 2009: 63).
} 
melancolia - experiência I, revelam um estado de destruição explosiva e, simultaneamente, engendram a potência de uma implosão incendiária do corpo e da realidade ao redor.

O Atlas de Warburg supõe assim uma leitura que evidencia a exceção, em negação à falsa harmonia das conexões lineares entre os quadros da realidade, permitindo assim que a história sobreviva segundo outra montagem, segundo relações de correspondências entre os fatos históricos.

A partir desta reflexão, podemos pensar que, diferentemente da concepção benjaminiana, a experiência não fora completamente destruída ou, ainda que tenha sido, deixou rastros - pistas de um crime comum e partilhado - a partir dos quais é possível reconstituir não só o passado sublimado, mas ainda, "reconstituir o futuro". A ação imaginativa e mnemônica (tal qual a de um detetive), devolve ao sujeito sua experiência perdida e a possibilidade deste transformar seu futuro. Podese pensar, assim, que o próprio trauma de origem seria elaborado, transformando a condição melancólica primeva em potência de reconstituição da história de si e da realidade.

A ideia de "fracasso" ${ }^{84}$, a respeito das experiências revolucionárias que buscaram negar uma ordem estabelecida, pode ser

\footnotetext{
84 "Restam somente duas teorias que ainda indicam e praticam essa noção engajada de verdade: o marxismo e a psicanálise. Ambas são teorias de luta (...) sua história não consiste num acúmulo de conhecimentos neutros, pois é marcada por cismas, heresias, expulsões. É por isso que, em ambas, a relação entre teoria e prática é propriamente dialética; em outras palavras, é de uma tensão irredutível: a teoria não é somente o fundamento conceitual da prática, ela explica ao mesmo tempo por que a prática, em última análise, está condenada ao fracasso - ou, como disse Freud de modo conciso, a psicanálise só seria totalmente possível numa sociedade que não precisasse mais dela. Em seu aspecto mais radical, a teoria é a teoria de uma prática fracassada: 'É por isso que as coisas deram errado...'. Costumamos esquecer que os cinco grandes relatos clínicos de Freud são basicamente relatos de um sucesso parcial e de um fracasso definitivo; da mesma forma, os maiores relatos históricos marxistas de eventos revolucionários são descrições de grandes fracassos (da Guerra dos Camponeses
} 
compreendida como parte do processo de uma revolução permanente ${ }^{85}$. Apesar de todos os massacres, há uma experiência que foi vivida e, mesmo que "fracassada", deixa rastros: há corpos melancólicos que testemunham a perda e que, contraditoriamente, nos fazem lembrar dos ideais que ainda fumegam sob as cinzas de nossa experiência hipermoderna. Sendo assim, a experiência, tal como a entendia Benjamin, deve ser revista: podemos reconstituir o crime a partir da ação atenta de um anatomista da história que disseca e imagina seu próprio corpo em uma mesa mnemônica de autópsia.

Um rastro de meu diário de direção: "um começo, o corpo está prostrado em uma cadeira, o quadril pesa toneladas, é impossível se mexer. Outro começo: o público entra em cena. Recebem bisturis. Dentro da sala o corpo está deitado sobre uma mesa de dissecação. O público é convidado a iniciar uma autopsia deste corpo. Outro começo, começo 3: o corpo está suspenso, no teto, suspenso por cabos de aço. Durante um longo tempo estou ali imóvel, entregue ao meu próprio peso, sem que consiga resistir à gravidade. Os cabos se afrouxam um pouco e soltam o corpo que pára a sessenta centímetros do chão, antes que se estatele completamente, um pouco antes da morte, um pouco antes de sua derradeira dissolução.”.

Em todas as possibilidades de começo do espetáculo, o corpo, na cena inicial, está paralisado e fragilmente sustentado por algum aparato

\footnotetext{
Alemães, dos jacobinos na Revolução Francesa, da Comuna de Paris, da Revolução de Outubro, da Revolução Cultural Chinesa...). Esse exame dos fracassos nos põe diante do problema da fidelidade: como redimir o potencial emancipatório de tais fracassos evitando a dupla armadilha do apego nostálgico ao passado e da acomodação demasiado escorregadia às "novas circunstâncias". (ZIZEK, 2011: 21).

${ }^{85}$ Para Kierkegaard, o processo revolucionário não envolve um progresso gradual, mas um movimento repetitivo, um movimento de repetir o passado várias vezes. (ZIZEK, Slavoj. Primeiro como tragédia, depois como farsa. São Paulo: Boitempo, 2009: 79.)
} 
externo (cênico) que lhe imprime - em alguma medida - algum vetor de violência contra o qual este corpo deve resistir.

Cena inicial "oficial" de Anatomia da Melancolia-experiência I: o corpo da cena está tragado pela gravidade, não há resistência, não há oposição em relação ao mundo externo, nem tampouco oposições entre os apoios e os vetores internos de movimento de seu próprio corpo. Massa amorfa e imprestável. Primeira fase do trauma ocidental capitalista. Trata-se de um corpo similar ao objeto mercadoria, inócuo, vazio, cuja subjetividade se encontra completamente escondida, necessitando ainda de um trabalho, no sentido benjaminiano ${ }^{86}$, sobre esse vazio para que uma potência emerja de suas ruínas melancólicas. Esse trabalho começa a se esboçar na segunda cena (quadro) de Anatomia da Melancolia-experiência I.

O primeiro dispositivo que precisei buscar, para este corpo melancólico, foi justamente o de tradução deste esvaziamento em uma "alma hiperbólica", esta espécie de linguagem do vazio. Não se tratava de preencher o vazio, mas de fazê-lo falar, como os sussurros do passado que devem ser escutados. Eu devia traduzir a ausência melancólica em ação, devia "hiperbolizá-la" em uma linguagem deste corpo melancólico: em uma corporeidade da ausência.

A primeira cena de Anatomia da Melancolia - experiência I é o rastro da venda de minha alma ao diabo: um corpo que virou mercadoria. Coloco-me sobre o assoalho da sala de apresentação, entrego meu corpo completamente ao chão, sinto o peso do meu corpo como se

\footnotetext{
86 "Essa ligação instigante se baseia na importância do conceito de "trabalho" (...),um lembrar ativo: um trabalho de elaboração e de luto em relação ao passado, realizado por meio de um esforço de compreensão e de esclarecimento - do passado e, também, do presente. Um trabalho que, certamente, lembra dos mortos, por piedade e fidelidade, mas também por amor e atenção aos vivos". (GANEGBIN, 2006: 105).
} 
pesasse toneladas e, no entanto, sou apenas a carcaça de um corpo morto, sem aura, sem "dentro", sem sangue. Quanto mais eu me entregava à gravidade, mais imóvel eu ficava, meu tônus estava ausente, como se todos os meus músculos estivessem flácidos, eu era uma massa amorfa, esvaziada, dissolvida no espaço, confundida com o próprio piso, em “demissão subjetiva", tal qual uma mercadoria, eu era meu próprio objeto de fetiche ${ }^{87}$. Eu estava assim indiferenciada da própria mercadoria, ou seja, um corpo cuja subjetividade se encontra anulada, dissolvida, assim como meu próprio tônus. Era impossível mover-me, impossível usar qualquer apoio do corpo para criar uma oposição e me deslocar, para empurrar o chão em algum ponto e, assim, realizar qualquer movimento ou deslocamento.

A melancolia pode ser apreendida como uma corporeidade que resistiu ao total desaparecimento e extinção do corpo. Este corpo apresenta-se como uma evidência da indestrutibilidade da alma, dada a permanência de seus rastros que instauram uma linguagem de sobrevivência, esburacada e lacunar, mas que resiste. A melancolia seria o rastro que nos faz lembrar que a potência utópica deste corpo deve estar escondida em algum lugar, soterrada em nosso próprio corpo social e que pode ser vista de forma fugidia em pequenos cristais que emergem dos choques incrustados nas imagens dialéticas. Como rastro, a melancolia é um índice de que ainda não desaparecemos, de que ainda estamos aqui ainda que sob a condição da ausência e da invisibilidade -; rastros de

\footnotetext{
${ }^{87}$ Com relação ao mundo fetichista das mercadorias, é digno de nota que Benjamin tenha encontrado o potencial emancipatório da experiência artística das vanguardas não no nível da consciência sustentada pela contemplação visual, mas na dimensão tátil incorporada na prática habitual: "Pois as tarefas que estão diante do aparato perceptivo humano em momentos históricos cruciais não podem ser realizadas somente por meios visuais - isto é, pela contemplação. Elas são gradativamente aprendidas - a partir das dicas da percepção tátil - pelo hábito.” (Benjamin, 2013c: 100).
} 
uma alma sobrevivente, corporeidade capaz, talvez, de resistir aos massacres impiedosos do capitalismo hipermoderno.

Este corpo é assim um inquieto sujeito que, movido pela tristeza, vazio e falta, sobrevive e age a partir de seu próprio abatimento e tédio: recolhe os rastros de suas experiências fraturadas em um projeto de revolução permanente ${ }^{88}$, e em vista de uma outra anatomia, para um corpo tanto estético quanto ético e político.

Se a primeira cena do espetáculo parte da imobilidade, a partir de um segundo momento meu enunciado era o de ir ao extremo tônico destas extremidades que começavam a ressoar no restante do corpo em torções, deformando-o, tornando-o um "corpo torto" em hipertrofia e hipertônus. A partir de espasmos hipertônicos iniciados nos pés, mãos e cabeça, ultrapassava-se o estado anterior da paralisia (estado de uma hiperbólica prostração), como se eu levasse o corpo às últimas consequências do trauma, ao extremo das oposições, das torções, das tensões. Os choques que foram absorvidos (e esquecidos) eram relembrados através dos espasmos.

Após um longo tempo, este enunciado que chamei de "paralisia" soma-se a outro, "o furor”: a partir das extremidades (mãos e pés), pequenas irrupções e explosões do corpo passam a ocorrer. Essas

\footnotetext{
${ }^{88}$ Procuramos usar o termo aqui para descrever os sucessivos movimentos de "furor" do corpo melancólico. Mas o projeto da revolução permanente foi desenvolvido por Leon Trostky, em diversos textos. A teoria da revolução permanente em sua formulação de 1905 pode ser resumida como se segue: "a vitória completa da revolução democrática na Rússia somente pode ser concebida na forma de ditadura do proletariado seguido pelos camponeses. A ditadura do proletariado, que inevitavelmente colocaria sobre a mesa não somente tarefas democráticas, como também socialistas, daria, ao mesmo tempo, um impulso vigoroso à revolução socialista internacional. Somente a vitória do proletariado do Ocidente poderia proteger a Rússia da restauração burguesa, dando-lhe a garantia de completar a implantação do socialismo." (TROTSKY, 1983: 59).
} 
explosões criavam uma consequência no restante do corpo que se chocava contra o chão, como se esse estivesse sendo arremessado de um lado para outro, mas não por iniciativa própria (não havia qualquer investimento libidinal, qualquer "condição", para isso). O estado de (não) ação do corpo revelava esta "demissão subjetiva" do melancólico, cujo furor advinha, dialeticamente, da potência que a extrema angústia hiperbólica imobilidade tributária deste vazio traumático - acabava gerando, como um desejo de sobrevivência. O procedimento usado até este momento foi o de me aprofundar hiperbolicamente neste vazio e, após entregar todo o peso do corpo ao chão (carne, pele e ossos, chegando ao ponto de me indiferenciar do espaço, de demissão absoluta do sujeito), emergia uma potência explosiva a partir das extremidades do corpo, dos pés e mãos que tateiam o mundo, que fazem contato com a realidade externa. $\mathrm{O}$ movimento irruptivo advinha da necessidade de sobreviver e resistir, negando e contradizendo o primeiro estado melancólico do início da peça: o da passividade e da entrega sem resistência.

A paralisia melancólica inicial condensava portanto os sussurros do passado que, naquele momento, ainda se encontravam apaziguados em nosso estado de exceção normatizado, sublimavam uma potência de fúria que teve que ser represada. Foi, no entanto, o trabalho a partir desta prostração, deste esvaziamento de linguagem, propriamente, que o trauma pode vir à tona a partir das oposições do corpo, em uma implosão deste corpo: partindo das tensões e dos espasmos hipertônicos, tanto o trauma quanto a fúria melancólica emergiam e se faziam ouvir.

Mais à frente, esta ação furiosa que teve início nas extremidades do corpo na Cena 2, engajará o corpo inteiro: a partir da oposição extremada, da tensão hiperbólica entre os muitos vetores deste corpo 
(deste "trabalho do corpo sobre o trauma"), na Cena 4 dá-se início ao deslocamento do corpo no espaço e seu estado inicial de total imobilidade, de surdez, emudecimento e cegueira é finalmente transformado em uma explosão melancólica, em todas as direções e planos do espaço. Nesse momento, o sujeito emudecido pelo trauma ganha visibilidade, emergindo de suas ruínas recalcadas, conseguindo executar sua primeira frase de movimento no espaço.

Os furores desencadeados a partir da profunda prostração e imobilidade da primeira cena podem ser vistos como aqueles lampejos das vozes recalcadas, como uma memória involuntária que tanto abate (por ser traumática) quanto anima o corpo melancólico. O sujeito, ainda que aparentemente emudecido, subjaz no inconsciente de uma história coletiva e social massacrada. Parece necessário ir ao extremo dos conflitos até que destes choques seja gerado algum deslocamento. A partir da "explosão" deste corpo (subjetivo, social e do indivíduo), uma nova realidade, ou ao menos um "raio" utópico parece emanar.

Se de um lado o discurso dos dominantes brada: “- Apague as pegadas!", tal como no brilhante poema de Bertolt Brecht (2012: 57), o corpo melancólico de Anatomia da Melancolia - experiência I recolheos, em forma de trauma, em seu próprio corpo, reconstituindo a história em uma dramaturgia feita das fraturas dos crimes, atualizando dialeticamente o passado em um tempo do "Agora", Jetztzeit, de Benjamin.

Podemos dizer que a melancolia é o próprio rastro de nossa alma, é um estado anímico que atesta tanto a ausência (falta) quanto nos lembra da presença do que foi esquecido. É desta operação mnemônica realizada na corporeidade melancólica, que reside a potência de leitura contestatória e crítica deste corpo. A melancolia seria assim um estado 
crítico e de sobrevivência de uma alma coletiva emudecida e devastada, evidenciando a capacidade desta alma resistir, de suportar no mais alto grau a marca do momento crítico, de risco.

A partir da rememoração dos rastros soterrados, à luz de nosso Agora - de uma ação mnemônica que constela o Agora ao Outrora - e de sua organização em uma dramaturgia cuja estrutura sintática é próxima à do Atlas de Warburg, a experiência social "fracassada" e "recalcada" pode ser re-imaginada e, ao ressignificar o passado, conferelhe uma espécie de sobrevivência messiânica, no limiar das épocas.

(...) não se pode dizer que a experiência, em qualquer momento da história, tenha sido "destruída". Ao contrário - e pouco importa a eficácia universal da 'sociedade do espetáculo' - deve se afirmar que a experiência é indestrutível, ainda que se encontre reduzida às sobrevivências e às clandestinidades de simples raios luminosos na noite. (DIDIHUBERMAN, 2012: 115)

Nossos rastros partilhados, tal como clandestinos "raios luminosos na noite", são índices de memória. Para Didi-Huberman, a experiência, ainda que emudecida sob uma subjetividade arrasada, permaneceria ali, sobrevivente, podendo ser rememorada. De um lado, o rastro corporifica um massacre social, de outro, manifesta a indestrutibilidade de uma experiência anímica, experiência que sobrevive "apesar de tudo". A melancolia, rastro que resiste sob nossos escombros, poderia ser vista como sintoma e antídoto, veneno e remédio de sua própria condição, tal como uma clandestina Mnemosyne que vaga pelas ruas noturnas, a procura de breves gestos e palavras, que compõem uma dramaturgia sobrevivente. 
Em Anatomia da Melancolia - Experiência I, estes clandestinos raios luminosos que jazem sob nossa profunda e insone história, sobreviventes de nossos escombros subjetivos, físicos e sociais, tornamse dispositivos de criação, possibilitando a rememoração de uma experiência emudecida pelos diversos abatimentos históricos contemporâneos, já anunciados por Walter Benjamin no início do século $\mathrm{XX}$. Durante muito tempo, este corpo em cena consegue realizar apenas dois movimentos: caído sobre seu quadril que é tragado pela gravidade, gira a cabeça para a esquerda ou para a direita e, em alguns momentos, move de modo quase invisível, os dedos dos pés enquanto os olha, sem que consiga reconhecê-los enquanto "seus" ou enquanto "pés", como se fossem uma parte suprimida (amputada) do restante do corpo. Exausto, após o extremo esforço para a execução destes dois movimentos e enquanto, cada vez mais, a gravidade o "traga" e o corpo derrete na cadeira (como se se confundisse com ela), ele se lança ao chão, ejeta-se, caindo no "espaço sideral", espaço composto pela trilha sonora, pelo piso espelhado de zinco e pela dramaturgia textual que corre em off nesse momento. Pouco a pouco, já jogado e tragado pelo chão, ainda que sem conseguir resistir ou se opor à gravidade, o corpo se deixa rememorar os choques na tentativa de que, ao repeti-los, possa lembrar do trauma vivido e até aqui emudecido. Alguns dispositivos para essa rememoração foram os seguintes:

- Atrofia muscular e articular que é iniciada nas extremidades (mãos e pés), o corpo todo acaba se contorcendo;

- Espasmos hipertônicos impulsionam o corpo a mover-se, ele maximiza a tensão de todos os músculos, consegue mudar suas 
direções no espaço, mas não consegue se levantar, permanece no plano baixo.

Esta linguagem melancólica, ela mesma rastro de uma experiência social silenciada, sussurro inaudível, seria capaz de operar a partir desses restos de história, restos sociais que recolhe enquanto disseca suas próprias fraturas. O processo de composição dramatúrgica desta corporeidade é, assim, próximo ao trabalho de dissecação do anatomista: poderíamos dizer que se trata de uma dramaturgia que disseca um corpo comum que ainda sobrevive sob os escombros.

\section{UTOPIA MELANCÓLICA: REVOLUÇÃO PERMANENTE}

Raymond Williams estabelece uma relação entre tragédia $e$ revolução, relacionando a tragédia do homem moderno ao seu contexto e experiência coletivos e sociais. Nas palavras do autor "O que importa, contra toda a dificuldade, é que as ideias recebidas não mais descrevem nossa experiência. A ideia mais comum de revolução exclui uma parte enorme da nossa experiência social." (WILLIAMS, 2002: 91)

Se os ideais de uma possível revolução do nosso presente nos parecem distantes, podem reaparecer, fugidiamente, a partir do choque entre rastros, de forma talvez obscura e obscena. Empregamos o termo a partir do latim Obscenus. A palavra obsceno está empregada aqui no sentido de algo que está para além ou fora da cena, fora da ordem do que é dado como norma ou representação (cênica e política), fora da cena teatral e política prevista, decodificável. Algo contrário à claridade tanto teatral quanto moral, o que não se pode ver, como a sombra da cena; ou ainda, a obscuridade que pode ser percebida em meio à claridade, seja ela 
teatral, seja ela social. Em Anatomia da melancolia - experiência I, a "ob cena" teatral equivaleria assim à " $o b$ cena" social, sendo uma a sombra dialética da outra. A corporeidade melancólica, presente em Anatomia da melancolia-experiência I, não como forma final, mas como linguagem inacabada, como ensaio de estranhar-se, parece inserir o corpo em uma experiência contraditória, no limiar da rememoração e da imaginação em relação ao nosso passado histórico.

Nas palavras de Mao Tsé-Tung, "Tudo sob o céu é um caos total; a situação é excelente." (apud ZIZEK, 2009: 70). Esse caos figura para o melancólico como uma oportunidade revolucionária: diante do aglomerado de ruínas, que a seus olhos - assim como para a Melancholia I de Dürer - reflete um esvaziamento anímico e social, resiste ainda uma fagulha - como um índice utópico - que o melancólico recolhe.

Sendo a melancolia um traço deste descarte, refugo de uma racionalidade hipermoderna, de um "eu" que se esvazia ${ }^{89}$, para o melancólico, este vazio é seu alfabeto, é ele mesmo, sua linguagem de contestação, potência de imaginação e de ação utópicas. A ideia de utopia é traduzida no liberalismo hipermoderno como "impossibilidade". Ora, trata-se de uma perversão ideológica do termo, de uma estratégia de amansar a ânsia revolucionária que moveria corpos críticos, insatisfeitos e inadequados à linguagem do capital.

Nossa concepção de utopia não se relaciona, todavia, a uma finalidade idealista e harmoniosa, ela é antes o cristal condensado que

\footnotetext{
${ }^{89}$ Segundo Freud, a distinção entre "trabalho de luto" e "melancolia" remete a um sentimento anterior à perda concreta, o sentimento do eu (Ichgefühl). Na compleição melancólica, esse sentimento é o de desvalorização, de empobrecimento, de esvaziamento: enquanto no luto é o mundo que se torna vazio devido à ausência da pessoa amada, na melancolia é o próprio eu que se esvazia, que não tem mais a força de se recompor, de viver novamente. (GAGNEBIN, 2009: 105)
} 
eclode de uma imagem dialética, que emerge da saturação de tensões que ocupam este corpo melancólico e que se configuram como uma espécie de linguagem melancólica dos conflitos históricos. Se para Baudelaire, como visto anteriormente, a linguagem da arte moderna nasceria da própria experiência do homem com a mercadoria, a utopia, assim como essa corporeidade melancólica, só pode ser reconhecida na experiência do homem com seu "Agora" histórico, à escuta daquilo que foi esquecido, sensível à tradição utópica do passado ${ }^{90}$. Essa corporeidade melancólica, fazendo emergir em si mesma - microcosmo - as contradições que formaram suas ruínas - macrocosmo -, anuncia-se como uma oportunidade utópica que emerge das cinzas, como um raio de luz irrompendo de nossa amnésia e breu profundo.

Ao descrever a melancolia hipermoderna, procuramos demonstrar, ao longo desta dissertação, que há inúmeras relações entre este corpo e o desenvolvimento sócio-metabólico do capital, diferentemente das causas da melancolia renascentista ${ }^{91}$, por exemplo, sobre a qual não nos

\footnotetext{
90 'Florença, Batistério. No portal, a 'Spes' (Esperança) de Andrea Pisano. Está sentada e ergue, desesperada, os braços para um fruto que não alcança. E no entanto é alada. Nada de mais verdadeiro." (BENJAMIN, 2012a.: 47). Há, na alegoria da escultura descrita por Benjamin, uma contradição entre espera, desespero e esperança. Bloch também descreve a mesma escultura "embora seja alada, ela está assentada esperando e, apesar das asas, levanta os braços, como Tântalo, na direção de uma fruta fora do seu alcance. Portanto, a esperança, sendo bem menos aquinhoada do que a memória, pode parecer um mal se tomada pelo lado da incerteza, e a esperança ilusória, infundada, certamente o é. (...) Tanto mais distante do mal está a esperança bem fundada, isto é, mediada pelo possível real, tão distante até do fogo-fátuo; ela representa justamente a porta no mínimo entreaberta que parece levar a objetos agradáveis, num mundo que não se tornou uma prisão." (BLOCH, 2007: 327).

91 “(...) as razões do abatimento melancólico já não se explicariam pela acedia, pois a melancolia passava a designar um estado de espírito diferente: o desânimo e a desinibição do homem renascentista diante dos novos recursos investigativos que caracterizaram o avanço da ciência de seu tempo. O melancólico, face às descobertas científicas que propunham uma nova abordagem - racional e investigativa - dos mistérios da natureza, sentiria a nostalgia da verdade revelada. A possibilidade, ou pelo menos o desejo de domínio racional do real, teria deixado o homem renascentista diante da perda do sentido metafísico do mundo." (KEHL, 2009: 70).
} 
detivemos aqui. O corpo melancólico, presente em Anatomia da Melancolia - Experiência 1, resiste no limiar entre a morte de uma determinada existência do corpo hipermoderno e uma outra anatomia desse corpo. Como um trabalho a partir da devastação dos corpos hipermodernos pode potencializar uma revolução permanente entre o eu individual e o eu partilhado? Revolução que se move a partir das ruínas de nosso corpo em falência?

Em Anatomia da Melancolia - experiência 1, as relações micropolíticas da cena - a deformação do corpo, por exemplo - espelham a deformação e o inacabamento de um corpo macropolítico de Estado, assim como pode-se pensar que o próprio corpo da cena é, ele mesmo, um macrocosmo político, borrando as fronteiras entre as grandezas desses dois territórios: o da atuação política e o da atuação artística. $\mathrm{O}$ trabalho sobre este corpo está alicerçado neste limiar do artístico e do político-social e, contrário a uma suposta fronteira entre essas duas instâncias, evidencia que esse corpo cênico é também um corpo político, em sua própria configuração, desfiguração, dissolução e ausência:

Não foi o mundo que se perdeu, fomos nós que perdemos o mundo e o perdemos sem parar; não é ele que em breve vai acabar, somos nós que estamos acabados, amputados, cortados, nós que recusamos alucinadamente o contato vital com o real. A crise não é econômica, ecológica ou política, a crise é antes de tudo crise de presença. A tal ponto que o must da mercadoria - o iPhone e o Hummer, em geral consiste em uma aparelhagem sofisticada da ausência." (COMITÊ INVISÍVEL, 2016: 35)

O corpo tenta rigorosa e ferozmente se "desinvestir" de sua individualidade, por isso deforma-se a todo tempo, como se buscasse reencontrar um corpo comum em si, um corpo social que escapa à 
"ordem liberal do indivíduo", um corpo que seria, ele mesmo, a própria medida e potência de resistência à desordem e à morte. Nossa utopia não se liga assim, a um ideal a ser alcançado, mas sim um processo revolucionário feito de quedas e suspensões, como os movimentos do corpo em Anatomia da melancolia - experiência I: processo feito de de ensaios, de tentativas ${ }^{92}$ que se relaciona ao desejo de mudança, à contestação que move esse corpo.

A melancolia retira o corpo de sua adequação e passividade administrada pelo tempo do capital. O que o corpo melancólico anseia é, ao contrário de negar o vazio, assumir sua falta, a ausência de uma experiência autêntica, em vista de superar sua própria melancolia, constituindo aquilo que chamo de uma alma hiperbólica, ou seja, uma corporeidade utópica a partir do vazio. Esse vazio utópico - espécie de nostalgia do futuro - embora oriundo e construído a partir de nosso passado histórico, não pretende alcançar uma unidade perdida, ou uma voz coletiva uníssona. A melancolia atual não anseia recuperar uma subjetividade perdida e que não mais se encontraria nos antigos ideais modernos de nossa formação, ciência e governo. A melancolia pode ser vista como a saudade de uma utopia que não reside no passado, tampouco em um futuro longínquo, mas em um "Agora" (Jetztzeit) benjaminiano, e que pertence talvez a um tempo messiânico:

\footnotetext{
${ }^{92}$ Para o filósofo romântico libertário Gustav Landauer, em sua obra A Revolução (1907), a utopia tem o sentido de um "ideal social legitimamente oposto ao estado de coisas existente." (LÖWY; SAYRES, 2008: 218). Para Bloch, em seu livro Geist der Utopie (1918), a expressão "realidade utópica" designa uma forma de realidade superior à vulgar facticidade empírica, tendo ainda uma dupla função: "cultivar de novo todo o passado e deliberar uma nova maneira acerca de todo futuro." (LÖWY; SAYRES, 2008: 218).
} 
O próprio Messias, apenas ele, é que perfaz todo o advir histórico, no sentido que só ele liberta, cumpre, leva ao cabo a sua relação com o próprio messiânico. Eis por que nada de histórico pode, por vontade própria e por si mesmo, querer se referir ao messiânico. Eis por que o Reino de Deus não é o telos da dinâmica histórica; ele não pode ser posto como meta. Visto historicamente, ele não é meta, mas fím. Eis por que a ordem do profano não pode se edificar segundo o pensamento do Reino de Deus, eis por que a teocracia não tem nenhum sentido político, mas tãosomente um sentido religioso. Ter negado com toda a intensidade possível a significação política da teocracia é o grande mérito de $O$ Espírito da utopia de Bloch. (BENJAMIN, 2010: 206)

Para Benjamin, o Reino de Deus não é a meta (telos ou Ziel), mas o fim (Ende) da dinâmica histórica. Benjamin haveria de retomar essa afirmação bem mais tarde, em uma das observações das teses Sobre o conceito de História: “O Messias interrompe a História; o Messias não surge no final de um desenvolvimento.” (BENJAMIN, 2012b: 20) ${ }^{93}$.

\footnotetext{
93 “Já puderam perceber que, em toda a obra de Kafka, o nome 'Deus' não aparece. E nada há mais vão do que introduzi-lo na interpretação dessa obra. Quem não entende o que proíbe a Kafka usar esse nome não entende uma linha sequer deste autor" (BENJAMIN, 2016: 256). Tal observação, escrita por Walter Benjamin, deve nos servir como sinal de prudência: nos caminhos das diversas interpretações da sua obra, os motivos teologia e messianismo acabam se tornando armadilhas perigosas, até porque, muitas vezes, remetem à louvável intenção de reconciliar aspirações religiosas e lutas políticas. O messianismo tem para Benjamin estrita proximidade com o materialismo histórico e, justamente por isso, não pode ser visto de maneira religiosa, mas sim filosófica, teológica. É o que aparece numa célebre observação de nosso autor, escrevendo sobre o próprio pensamento, e que se encontra justamente no aparato crítico das Teses. Benjamin escreve: "Meu pensamento se comporta com a teologia da mesma forma que o mata-borrão com a tinta. Ele fica totalmente embebido dela. Mas se fosse seguir o mata-borrão, então nada subsistiria daquilo que está escrito" (BENJAMIN, 2012b: 148). A primeira tese já trata, de modo enigmático, da estreita relação que, segundo Benjamin, deve unir o materialismo histórico e a teologia, mas no mundo concreto da luta dos seres humanos por sua existência partilhada: "Como se sabe, deve ter havido um autômato, construído de tal maneira que ele, a cada jogada de um enxadrista, respondia com uma contrajogada que lhe assegurava a vitória da partida. Diante do tabuleiro, que repousava sobre uma ampla mesa, sentava-se um boneco em trajes turcos, com um narguilé na boca. Um sistema de espelhos despertava a ilusão de
} 
A motivação para a criação da corporeidade melancólica parece ser esta interrupção da história linear, movida por uma saudade de utopia. Em Anatomia da melancolia - experiência I, essa saudade parece ser o motor de deslocamento do corpo em seu tempo-espaço histórico. No entanto, esta corporeidade pode ser vista como uma pseudo conclusão pois trata-se, em verdade, de uma dialética sem síntese, da sobrevivência de um corpo em estado de choque e de dilaceramento. Esta linguagem não parece apontar para uma superação das tensões dialéticas presentes neste corpo, mas as mantém em suspensão, como sobreviventes que anseiam por uma redenção. A sobrevivência se faz de forças opostas que permanecem em choque, em trabalho permanente de rememoração e fabricação de linguagem, de uma escrita que conjugue o Agora e o Outrora. Gagnebin chama atenção para o fato de que (2009: 154-155):

(...) não é a sensação em si (...) que determina o processo da escrita verdadeira, mas sim a elaboração desta sensação, a busca espiritual do seu nome originário, portanto, a transformação, pelo trabalho da criação artística, da sensação em linguagem, da sensação em sentido. Não se trata simplesmente de reencontrar uma sensação de outrora, mas de empreender um duplo trabalho: contra o esquecimento e a morte, um, o lado "objetivo" do tempo aniquilador; contra a preguiça (...), outro, o lado "subjetivo" do escritor que se põe à obra.

Assim, o rastro melancólico, como sintoma da hipermodernidade e índice de sobrevivência, poderia ser, quiçá, superado quando traduzido

que essa mesa era transparente de todos os lados. Na verdade, um anão corcunda, mestre no jogo de xadrez, estava sentado dentro dela e conduzia por fios a mão do boneco. Pode-se imaginar na filosofia uma contrapartida dessa aparelhagem. O boneco chamado 'materialismo histórico' deve ganhar sempre. Ele pode medir-se, sem mais, com qualquer adversário, desde que tome a seu serviço a teologia, que, hoje, sabidamente, é pequena e feia e que, de toda maneira, não deve deixar-se ver." (BENJAMIN, 2012b: 15). 
em corporeidade. Esta escrita melancólica talvez seja a linguagem do "anjo da história" que se dirige ao futuro, sem desligar seu olhar sobre o passado: este "anjo" está em voo permanente, suspenso por fios contraditórios desta nossa melancólica história, tecendo uma trajetória utópica para este corpo em uma perspectiva materialista e messiânica.

\section{DESORDEM E TRAGÉDIA}

Não seria a melancolia a linguagem de uma civilização que já morreu, uma linguagem que nos permite lembrar do passado e recriar o futuro? Uma linguagem que advém deste vazio gerado após inúmeras supressões subjetivas do corpo? Se, de um lado, trata-se de um corpo que testemunha a sua própria morte, a morte de sua existência coletiva e social, de outro, antiteticamente, esse mesmo corpo está inquieto em relação a este estado de abatimento, não se deixando destruir por completo. Esse corpo "permanece" diante de seu fim.

Diante de uma ordem social já morta, esta corporeidade "da falência" desnaturaliza o corpo e a narrativa histórica, abrindo espaço à uma potência que emerge de seu deserto, de seu esvaziamento subjetivo. Este melancólico, como o anjo da história, caminha de costas para o futuro, enquanto escava o passado que vai deixando para trás, recolhendo seus rastros, inquieto diante dos crimes que testemunha e participa, inquieto diante da "ordem" de um total (des)governo de si e do outro, do (des)governo de um progresso histórico brutal, de um (des)governo do nosso corpo social $^{94}$. Em Anatomia da Melancolia - experiência I,

\footnotetext{
${ }^{94}$ Sobre este (des)governo podemos pensá-lo como uma forma de descontrole do Estado (ilegalidade também atuante em nossas relações micropolíticas), tributário, em verdade, de um "não" cumprimento das leis constitucionais: "No Brasil, nem em
} 
proponho-me a fazer emergir essa tragédia - esses crimes - no corpo, talvez como uma primeira ação em vista de uma outra anatomia política, de onde advém certa esperança. Para que enxerguemos nossa sombra histórica é preciso ao mesmo tempo sermos contaminados por ela e negála, colocando-nos em experiência de resistência e contradição.

A busca por essa corporeidade melancólica parece ser a de descobrir e revelar a estrutura da tragédia presente em nossa cultura, como nos diz Raymond Williams: "Tragédia, dizemos, pertence a uma experiência mais profunda e mais íntima, ao homem e não à sociedade." (2002: 89-90). Para o autor, no entanto, ao contrário do que vemos no vocabulário cotidiano da imprensa e da indústria cultural, "as desordens gerais (...) podem ser reduzidas a sintomas do único tipo de desordem que estamos prontos a reconhecer: a falha na alma.". Não poderíamos, assim, chamar tais acontecimentos, ligados à história contemporânea, de tragédia: “Guerra, revolução, pobreza, fome; homens reduzidos a objetos e mortos a partir de listas; perseguição e tortura; (...) por mais próximos e persistentes que sejam os fatos, não devemos nos comover, num contexto de tragédia. Esta, sabemos, diz respeito a outra coisa.". Segundo Williams, seria necessário procurar um novo e universal sentido de tragédia: "Estamos procurando a estrutura da tragédia na nossa própria cultura. Uma vez que comecemos, na experiência e depois na análise, a duvidar da ideia usual do século XX, outras direções parecem se abrir.” (WILLIAMS, 2002: 90).

períodos constitucionais nem as transições jamais inibiram o uso da violência ilegal (prisões arbitrárias, emprego corriqueiro de forças policiais contra as multidões, tortura e execuções sumárias) contra a sociedade. No Brasil, democracia e transição democrática jamais inibiram a prática da violência ilegal. Recentemente, um cientista político, Philippe Schmitter, dizia que 'não existe no mundo país com instituições democráticas que violem tanto as suas próprias leis quanto o Brasil. É o descontrole do Estado."” (PINHEIRO, 1991: 8-9). 
Em sua condição dilacerada, poderíamos dizer que o corpo melancólico está em falta de um sentido universal. Mas, tal como nos diz Williams, não existem sentidos e conceitos universalmente válidos, o que chamávamos de tragédia em séculos anteriores não pode ser aplicado à nossa presente realidade histórica. Não se trata de encontrar uma nova resposta ou superação unívoca e universal para nossa hipermodernidade arruinada, trata-se antes de compreendermos a estrutura geradora desta melancolia, sendo essa própria estrutura um dos dispositivos de criação desta corporeidade melancólica em Anatomia da Melancolia experiência I. Se, tributários da visão individualista moderna, tendemos a entender a desordem e a tragédia como condição ou falha de uma alma individual, o que procurei analisar até aqui é que essa alma, na negativa da perspectiva do indivíduo, é uma alma social - objeto de falta deste corpo melancólico.

Contestando a perspectiva romântica de uma possível unidade, o que parece uma forma incoerente em relação à nossa sociabilidade hipermoderna, a utopia do melancólico não se refere a uma superação: a falta melancólica, esta espécie de saudade de um futuro, não anseia de fato por uma completude una, por um "fim", mas, antes, questiona as formas totalitárias geradoras da nova tragédia que marca nossa alma partilhada, da qual o individuo é um de seus ecos.

Entende-se que esta falta trágica ${ }^{95}$ é preenchida de rastros de um passado ainda presente, a partir dos quais pode-se elaborar uma

\footnotetext{
${ }^{95}$ Tomamos aqui a definição do trágico elaborada por Peter Szondi. Em seu Ensaio sobre o trágico, (SZONDI, 2004). Peter Szondi afirma que Hegel percebeu nas Lições sobre Estética a forma fundamental da tragédia grega: a contradição. A tragédia surge em um momento da vida social ática em que o desenvolvimento da democracia e da expansão comercial e imperial do Estado era determinado pelo surgimento de novas instituições, que fracionavam o sujeito, opondo-o aos valores da tradição, marcada pelos deuses, e também aos valores do estado nascente, caracterizado pela emergência de
} 
linguagem que constela um ponto de vista histórico ao estético. Esta falta melancólica poderia ser vista como a sombra de uma alma - hiperbólica -, alma que apreende sua realidade não como condição, mas como contradição dialética em sua complexidade tanto humoral e cinética, quanto histórico-social. Esta sombra não está presa ao passado, mas é forjada no presente, no Agora benjaminiano - Jetztzeit - onde os estilhaços do passado se constelam à saudade do futuro que impulsiona, move e desloca este corpo.

A melancolia pode ser vista como um estado que possibilita a sobrevivência do corpo diante da sequência ordinária de catástrofes da hipermodernidade. Sua resistência se faz dada sua capacidade de se manter em choque, de se manter em um estado de espanto - único meio de sobreviver -, como estratégia de não adequação à violência dos dias; corpo disposto a entristecer diante desta violência, não se deixando absorver por ela. Este corpo assimila a violência e a condição trágica de si e de seu contexto como material a ser afirmado e negado em sua dramaturgia: assimila a tragédia hipermoderna para simultaneamente negá-la a partir de seus fluxos energéticos e suspensões de movimento que compõem sua corporeidade contraditória.

É esta espécie de assimilação negativa que possibilita que o corpo não seja tragado pelo continuum trágico da história dominante. É por esse motivo que podemos talvez encarar este corpo melancólico como

normas opostas à subjetividade e aos princípios comunitários do ingênuo mundo épico. A característica fundamental da tragédia seria assim a dialética. O trágico seria assim uma radicalização da colisão formal presente no drama, levada ao extremo da própria destruição, um modo determinado de aniquilamento iminente ou consumado, justamente o modo dialético. Seria trágico apenas o declínio que ocorre a partir da unidade dos opostos, a partir da transformação de algo em seu oposto, a partir da autodivisão. Mas também só seria trágico o declínio de algo que não pode declinar, algo cujo desaparecimento deixa uma ferida incurável. Pois a contradição trágica não pode ser suprimida em uma esfera de ordem superior, a sua arena é a própria história, a história de um mundo que nasce entre os escombros do mundo harmônico da epopeia. 
potência de resistência e negação, como modo de viver uma vida já danificada, por meio da negação a esta mesma deterioração, existindo em um estado de contradição: infiltrado em sua época e resistindo à mesma, assimilando sem se fundir a seu próprio contexto. Tomando-se este corpo melancólico como uma espécie de desvio negativo, como instauração de distância para uma abertura de construção crítica, podemos dizer que os furores e abatimentos que caracterizam sua corporeidade são os respectivos e inerentes sintomas de um movimento de distanciamento e aproximação em relação a uma miséria partilhada. Este corpo revela nossa decadência comum e, dialeticamente, nossa potência de resistência e permanência em vista de outra ordem histórico-anatômica.

Neste processo de simbolização e criação artística, o corpo melancólico em Anatomia da melancolia - experiência I, abate-se diante de seu contexto, assim como ele próprio é, igualmente, causa de seu abatimento. Corpo e contexto operam em uma conexão liminar diante de sua própria falência. Sujeito e história, movimento e texto (fala), corpo e espaço, estão indissociados. O corpo é também contexto e contexto é também corpo: ambos em desordem, em hiperbólica decadência que caracteriza nossa hipermodernidade, ambos em falência. $\mathrm{O}$ texto e o movimento se interpenetram a todo instante como um reflexo dialético um do outro.

Este limiar, presente em Anatomia da Melancolia - experiência $I$, revela que só se pode pensar um corpo artístico se atentarmos para seu contexto político, inexistindo uma fronteira entre esses dois governos: micro e macro política, ambas desgovernadas, deformadas, danificadas, reflexos negativos uma da outra e que despencam no espaço, em desordem, revelando um estado de (anti)presença de exceção do corpo individual e histórico-social, esses estranhos-familiares. 
Retomando a primeira cena de Anatomia da Melancolia Experiência I, é possível testemunhar esse contexto trágico de desordem marcado na corporeidade melancólica. A sensação/imagem desta primeira cena pode ser descrita como se as partes do corpo estivessem fora de ordem, amputadas de seu lugar. O procedimento neste momento da obra era o de torção, substituição ou de supressão das partes, sendo que o corpo não age, mas sim, reage, é agido "por um outro", como se estivesse sendo manipulado por um duplo seu fantasmático, pela força hiperbólica da gravidade das leis humanas; meu corpo era a metonímia do peso morto de uma civilização danificada que carregamos em nossa própria fisicalidade.

Para o melancólico, esta gravidade é ressentida de maneira dilatada e dilacerante, hiperbólica, como se este corpo colocasse uma lente de aumento sobre as leis físicas e humanas. A hipérbole seria uma estratégia de desvio que, na escrita desta corporeidade, busca tornar visível aquilo que não enxergamos mais.

Os gestos e fala parecem não encontrar uma ordem possível para a emissão das ideias. O inacabamento e o despencar do corpo, em Anatomia da melancolia - experiência I, evidencia a desordem de uma época trágica, na qual nossa narrativa histórica se repete como um eterno presente, um corpo sem passado e sem futuro, suspenso, sem memória e sem história. Roberto Schwarz (SCHWARZ, 1999: 24-32) promove uma descrição exata que define o aspecto trágico de nossa época: "Vejam-se a respeito os esforços desenvolvimentistas do Terceiro Mundo (...), subsídios, endividamentos e decênios de sacrifício humano brutal não trouxeram a prometida modernização da Sociedade". Para Schwarz, com este fracasso abriu-se a época presente, trágica por ser marcada por "sociedades pós-catástrofe", onde o desmoronamento das antigas formas 
de sociabilidade dá a tônica. "A situação de vários países da América Latina hoje se pode caracterizar como de "desindustrialização endividada", com populações inteiras formadas por "não-pessoas sociais, ou seja, de sujeitos monetários desprovidos de dinheiro.”. A tendência de produção desses "sujeitos monetários sem dinheiro", restos da catástrofe, chega ao extremo "quando uma economia é expelida da circulação global, depois de a concorrência moderna the ter desativado os recursos locais: a massa da população passa a depender de organizações internacionais de auxílio, transformando-se em caso de assistência social em escala planetária.”. Por fim, para o autor, a tragédia se completa com a contradição insuportável de que "Droga, máfia, fundamentalismo e nacionalismo representam outros modos pós-catástrofe de reinserção no contexto modernizado.".

Nosso corpo histórico, embora tributário do esquecimento, está fundado sobre uma "desordem radical" que, contraditoriamente, o presentifica e o coloca em deslocamento, movido pela inquietação de encontrar seu objeto perdido, seu ideário e potência subjetiva-política. A prostração deste nosso corpo coletivo melancólico revela o desfalecimento de nossa experiência política, deformada por nossa própria constituição social, segundo a qual o corpo político - e nossa subjetividade histórica - tornou-se, ele mesmo, mercadoria. Talvez seja a partir desta desordem dos corpos que podemos trazer à tona a experiência anímica recalcada de nosso sujeito histórico, reconstituindo-lhe a utopia perdida. 


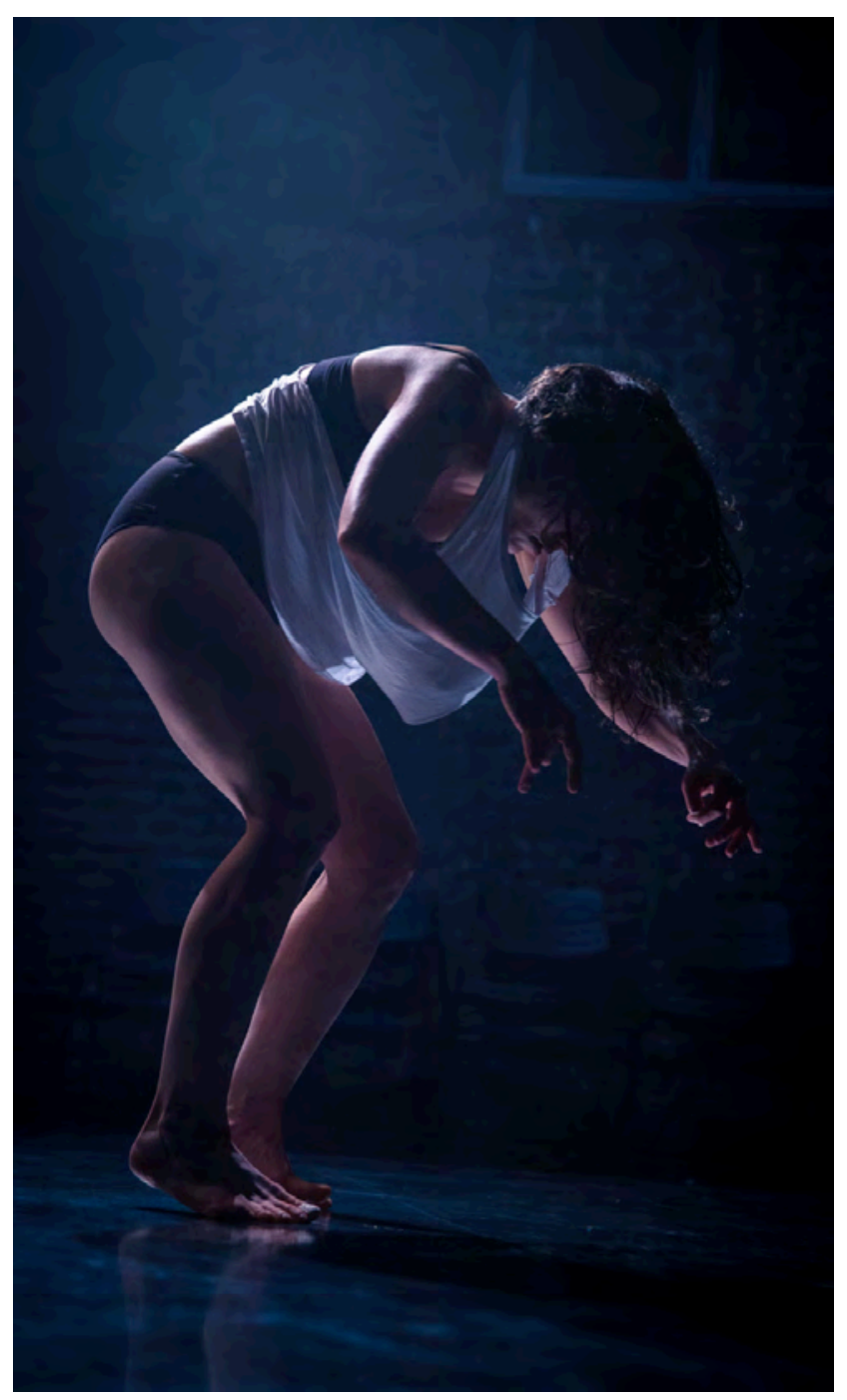

Imagem 6. ATROFIA MUSCULAR E MEMBROS FANTASMAS. Anatomia da melancolia - experiência I.

Foto: Otávio Dantas. 


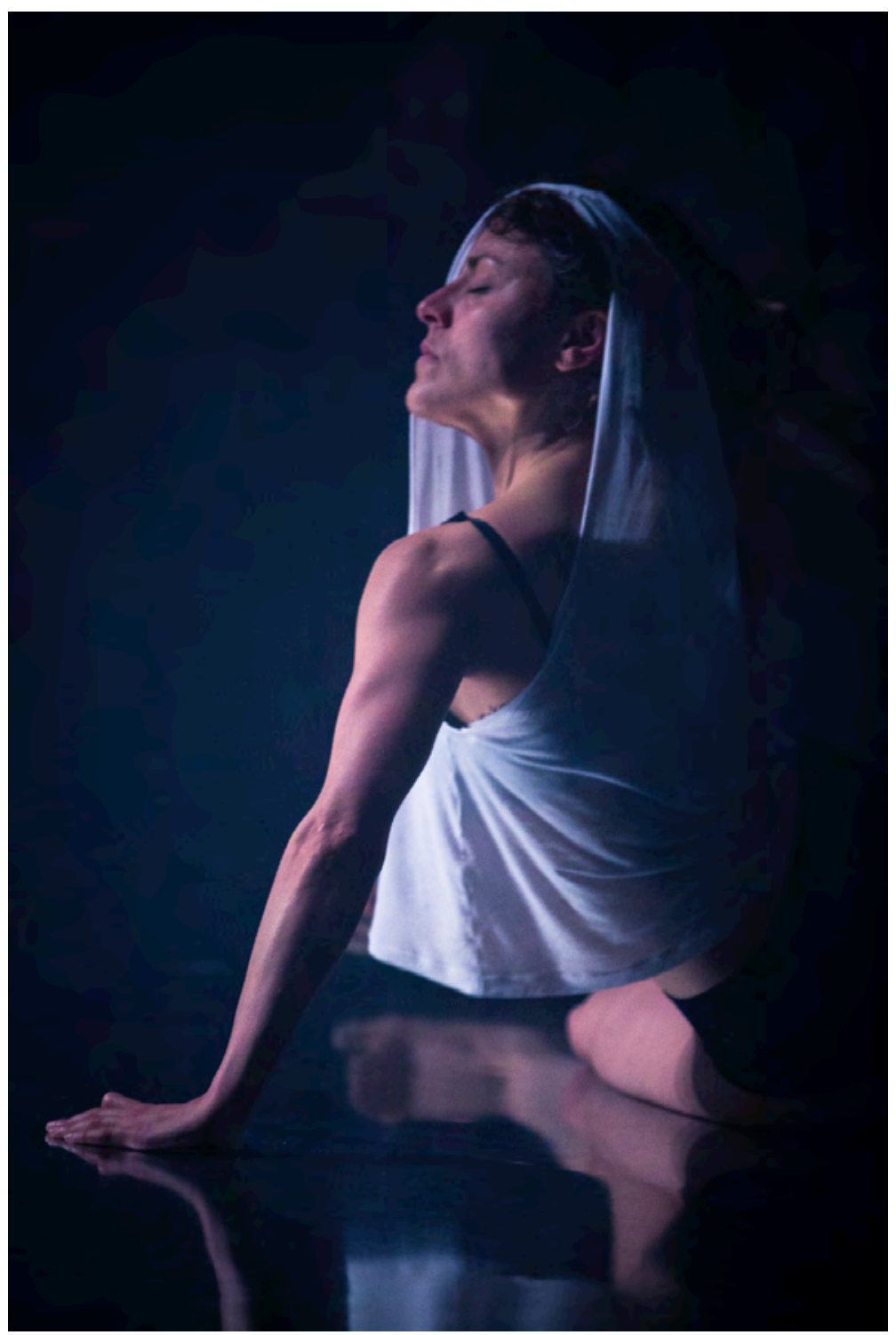

Imagem 7. Leitura a partir de DÜRER. Anatomia da melancolia - experiência I

Foto: Otávio Dantas. 


\section{CONCLUSÃO}

\section{CORPOREIDADE DA AUSÊNCIA}

Se de um lado o corpo melancólico, analisado durante toda esta dissertação, é tributário da mercantilização da modernidade, de um esvaziamento psíquico e criativo, procuramos demonstrar que é a partir do trabalho com seu próprio trauma, da elaboração desse vazio criado em sua alma, que seria possível transformar sua própria anulação de linguagem em uma linguagem do vazio, que poderia ser traduzida em uma "corporeidade da ausência". Tentemos desdobrar essa reflexão a partir de um comentário crítico-poético que o pensador Gershom Scholem ${ }^{96}$ envia a Walter Benjamin (SCHOLEM; BENJAMIN, 1993: 177), acerca do artigo que este último escrevera sobre $O$ Processo de Kafka:

Tão afastados estamos de ti?

Não haverá, ó Deus, nesta noite nem um sopro da tua paz, tua mensagem?

Esvaneceu-se a tua palavra no vazio de Sion ou nem sequer penetrou nesse reino mágico de aparências?

Nesta correspondência de 17 de julho de 1934, destinada a Benjamin, Gershom Scholem, escreve, contestando o artigo que o amigo

\footnotetext{
${ }^{96}$ Gershom Scholem (1897-1982) foi um historiador, teólogo e filólogo judeu-alemão que popularizou a história do misticismo e do messianismo judaicos. Um dos principais amigos e interlocutores de Walter Benjamin ao longo de toda sua vida, ficou conhecido como fundador do moderno estudo da Cabala. Foi o primeiro professor de misticismo judaico na Universidade Hebraica de Jerusalém.
} 
e interlocutor havia enviado, a propósito da obra de Kafka: "o mundo de Kafka é o mundo da revelação, embora naquela perspectiva que se volta para o seu vazio, para o nada." (SCHOLEM; BENJAMIN, 1993: 177):

Consumado quase até o fim o grande engano mundial. Despertai, ó Deus, os que foram trespassados pelo teu Nada.

Este comentário poético e crítico de Scholem a respeito da obra kafkiana espelha sinteticamente o olhar melancólico, aquele que, tensionado por forças contraditórias, parece encontrar uma revelação em seu próprio vazio; vazio de onde emerge e se revela a linguagem deste corpo, sem lei e sem direção:

\author{
Tão só brilha a revelação \\ no tempo que te repudiou. \\ E o teu Nada é a única \\ vivência que te restou. \\ Tão-só vem à memória \\ o vazio que rompe a ilusão: \\ o incontestável legado \\ do oculto tribunal. [...] \\ Do centro do extermínio \\ irrompe às vezes um raio \\ mas não se sabe em que direção \\ a lei nos apontou. (Idem)
}

Sob a perspectiva de Scholem, a respeito da obra kafkiana, o vazio é fonte e não falta, fonte de revelação, mesmo quando vinda "do centro de extermínio" matriz de uma linguagem que, para Benjamin, seria "tanto mítica quanto política" (Ibidem: 175-176). Essa linguagem desenha-se como as duas extremidades de um mesmo arco que atira uma 
flecha. Essa flecha traça uma escrita no espaço, uma linha de forças contraditórias que podemos entender como a escrita, a crítica, a teoria, a ação e o gesto tanto mítico quanto político de um corpo histórico, tal como a alegoria benjaminiana do "anjo da história", vestígio recuperado e mencionado diversas vezes ao longo de nossa dissertação.

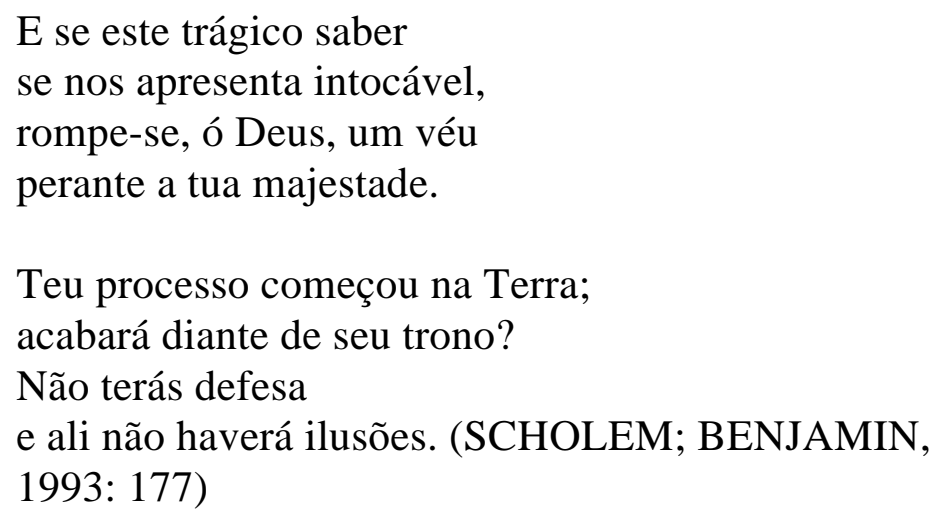

Quando Scholem escreve em seu poema “(...) o teu Nada é a única vivência que te restou", não poderíamos dizer que a experiência (vivência) teria sido completamente perdida na vida hipermoderna, pois ainda nos restaria este Nada deixado pela ausência de Deus "nesse reino mágico de aparências" (Idem):

\footnotetext{
Na balança de Jó

mede-se, exata, a nossa posição desesperados como no Juízo Final fomos totalmente descobertos.
}

Reino cuja ilusão ou aparência (que pode ser entendida como o capital de nossa hipermodernidade) é quebrada por um vazio que abre espaço para a memória de uma experiência espiritual: “Tão só vem à memória o vazio que rompe a ilusão (...)”. A memória ilumina um rastro deixado neste reino do "nada" (SCHOLEM; BENJAMIN, 1993: 177). O mesmo poema citado continua: 
Em instâncias infinitas

reflete-se o que somos

Ninguém conhece o caminho ao todo

e cada parte já nos cega.

A salvação fora do alcance,

estrela longínqua

e se pretenderes tê-la atingido

serás tua própria pedra no caminho.

Esse nada, não sendo falta, é a própria linguagem que sobrevive de uma experiência espiritual na Terra:

Entregue a poderes

que evocações já não controlam

vida alguma se desenvolve

que não se feche em si.

O vazio - esse Nada - índice revelador de uma experiência deixada, esquecida como um rastro, mas sobrevivente, transforma-se em dispositivo para esse corpo melancólico:

Quem aqui é o acusado?

Tu ou a criatura?

Se alguém te perguntasse

mergulharias em silêncio.

Pode-se levantar tal questão?

Seria a resposta indeterminada?

Ah, teremos de viver ainda assim até nos inquirir teu tribunal. (Idem)

Mais adiante, na carta de 20 de setembro de 1934 a Benjamin, Scholem nos esclarece ainda mais:

Entendo um estado em que a revelação parece destituída de significado, no qual ela consegue se impor na medida que é válida, mas nada significa. 
Quando desaparece a riqueza do significado e o elemento que surge se reduz à própria nulidade embora não desapareça (e a revelação é algo que surge), pois aí se revela o seu nada. (Ibidem: 197)

Assim como nos diz o Fausto de Goethe - "Em teu nada espero encontrar o Todo" (GOETHE, 2003: 316) -, esta ausência seria a antítese daquela hiper-realidade hipermoderna, que nos é a todo momento imposta $^{97}$. Este Nada, portanto, poderia nos revelar uma outra realidade que não esta, aparente, que nos absorve diariamente e que parece nos privar de experiências autênticas, "reais".

Perceberemos que esta realidade "mais que real" seria este "grande engano mundial" do poema de Scholem, engano que é o mundo descrito no Processo (1925) de Kafka, cujo protagonista sofre um processo incompreensível, por um crime que desconhece. O romance descreve um processo que se desenrola esvaziado de sentido aparente, cujo sujeito não tem qualquer "autoridade" (autenticidade) sobre o sentido de sua existência mesma (o sujeito não se reconhece como o autor do crime). A parábola Diante da Lei, parte do romance, é fundamental para se compreender o universo kafkiano; como também o temor e a resignação do indivíduo perante o poder inexorável do Estado. O texto foi escrito em 1915 e se configura como "o centro nervoso" do romance $O$ processo:

\footnotetext{
${ }^{97}$ Tal como nos diz Luciana Chaui-Berlinck (2008: 50), em seu Melancolia $e$ contemporaneidade, na sociedade pós-moderna "As imagens parecem preencher todo o tempo e todo o espaço real e imaginário, elas parecem ser tudo e todo o real, não há falta, não há lacuna, não há ausência, não há distância - isto é, não há tudo aquilo que é preciso para haver simbolização (...) é uma ultra realidade que se nos impõe. O sujeito, portanto, não simboliza, aceita como sua essa realidade 'mais que real', acreditando ver nela seu próprio reflexo (tem a ilusão de onipotência).".
} 
Diante da lei está um porteiro. Um homem do campo dirige-se a este porteiro e pede para entrar na lei. Mas $o$ porteiro diz que agora não pode permitir-lhe a entrada. (...) "Se o atrai tanto, tente entrar apesar da minha proibição. Mas veja bem, eu sou poderoso e sou apenas o ultimo dos porteiros. De sala para sala, porém, existem porteiros cada um mais poderoso que o outro. Nem mesmo eu posso suportar a simples visão do terceiro". (KAFKA, 1997: 237)

A ameaçadora fala do porteiro, dirigida a Joseph K., configura mais uma das situações de opressão cotidiana presentes no romance, assim definidas por Adorno:

Pela janela aberta, se via outra vez a velha senhora, que com uma curiosidade verdadeiramente senil agora havia passado para a janela que ficava defronte para continuar vendo tudo", lemos na cena da prisão no início de $O$ processo. Quem já não se sentiu observado da mesmíssima forma pelo vizinho em uma pensão qualquer; quem já não teve a intuição de um destino repugnante, incompreensível e inevitável? O leitor que conseguisse decifrar tais cenas saberia mais de Kafka do que quem encontra nele uma ilustração da ontologia. (ADORNO, 1998: 142)

O personagem do romance de Kafka é sintomático de uma modernidade cujo paradigma é a burocracia pura e simples, sujeito refém de um grande engano, refém de um processo burocrático que se baseia no acúmulo de honorários e de capital, gerando um vazio tanto moral quanto existencial. Tal é o mundo desta modernidade da qual somos um eco não tão longínquo.

Pode-se entender que este vazio de sentido é a antítese - o negativo, estranho-familiar - o "outro lado" do capital, ainda que tributário de seu próprio processo de acúmulo. Este corpo melancólico, tal como o protagonista de Kafka, é o réu de um processo cujo crime lhe 
é desconhecido, corpo que atesta a cisão entre sujeito moderno e mundo burocrático, cisão entre este "eu" e sua própria ação - crime - neste mesmo mundo. O que é revelado ainda, a partir desta percepção, é uma separação entre o gesto e sua própria autenticidade, entre o sujeito e a autoridade de suas ações: o sujeito não é mais o "autor" de seu crime que, no limite, é uma ação fruto de um grande engano social; crime que todos nós cometemos e não sabemos, dado que nossa própria história nos é desconhecida. Tendo em perspectiva o sistema hipermoderno de trabalho, é o próprio processo de produção que não pertence mais ao corpo, levando-o a um vazio de sua própria existência, corpo ausente de si mesmo, de sua legitimidade mesma, autor de um crime do qual ele sequer se lembra, crime que precisa ser rememorado.

Procuramos demonstrar ao longo de nossa dissertação, que este vazio da experiência embora gerado pela ilusão da modernidade, também contradiz e nega a aparência de sua época. É desta contradição, do limiar do sintoma e da potência de resistência, que nasce a ação melancólica. Essa dinâmica de forças antagônicas compõe uma corporeidade dialética, em que, todavia - como nos diz Scholem em seu poema -, "a salvação está fora do alcance". Sobrevivente à contradição, não poderíamos dizer que para o corpo melancólico haveria em seu horizonte a superação deste nada: “(...) e se pretenderes tê-la atingido / serás tua própria pedra no caminho." (SCHOLEM; BENJAMIN, 1993: 177). Sendo o vazio o próprio objeto e sujeito - "criador" e "criatura" - dessa corporeidade melancólica, diferentemente do enlutado, este corpo não supera o vazio, mas trabalha "com ele", processa o vazio, traduz este "Nada de significado" em linguagem. Esta corporeidade da ausência opera no limiar de fios tensionados e contraditórios: trata-se de um corpo cuja "qualidade" é a da sobrevivência e não a da vivência, da redenção, da 
verdade, embora a busque. Este corpo sobrevive em processo (tal como o título do romance de Kafka), em uma dialética sem síntese, existindo na contradição entre as leis esvaziadas de significado, sobrevivendo como um resistente, no limiar de forças em choque.

Em sua carta de 20 de julho de 1934, Benjamin responde à ressalva feita por Scholem a respeito de Kafka: “(...) qualquer tipo de superação deste nada, como pretendem os intérpretes da linha teológica em torno a Brod, teria sido um horror para Kafka [!]” (Ibidem: 180). No Processo de Kafka, assim como para o corpo melancólico, não há uma "síntese redentora": este corpo age nas passagens entre tensões contraditórias que se encontram suspensas, em choque dialético, porém sem superação. Tomando as palavras de Scholem: "Quem é aqui o acusado? Tu ou a criatura? Se alguém te perguntasse mergulharias em silêncio" (Idem). O melancólico é assim aquele que age por meio de perguntas, mas que cai em silêncio, para o qual não há resposta, síntese, em uma ânsia messiânica, mas cuja vivência está marcada pela própria ausência desse Messias, pela falta de uma verdade à qual poderia se fiar (dado que para ele o mundo perdeu seu significado), corpo ocupado por um Nada prenhe de forças contraditórias - de tensões que operam em choque no corpo, intenções de movimento sem direção precisa, sem "verdade", sem "sentido". O melancólico, presente em Anatomia da Melancolia - Experiência I, este sujeito inconcluso, contraditório, em processo, pode ser visto ao mesmo tempo como matéria e como alegoria de um processo revolucionário: é o ser da passagem, da transição, do limiar, cujo movimento nasce do próprio vazio exterminador, mas cuja direção (que suporia um fim, uma conclusão) no tempo-espaço histórico 
lhe é desconhecida: "Do centro do extermínio irrompe às vezes um raio ${ }^{98}$ mas não se sabe em que direção a lei nos apontou." (Ibidem: 177).

Conforme procuramos demonstrar nos capítulos anteriores, o vazio seria assim sintoma de "um grande engano mundial"99 e também o próprio rastro de sua experiência autêntica: "Teu processo começou na Terra; acabará diante de seu trono? Não terás defesa e ali não haverá ilusões." . Esse vazio dialético parece ser um dispositivo capaz de reconstituir a este corpo a memória de sua experiência onde não haveria ilusões. Daí a presença do vazio como motor de movimento para o corpo melancólico: desse Nada implodem as tensões em choque que agem esse

\footnotetext{
${ }^{98}$ A imagem do relâmpago é fundamental, na obra de Benjamin, como alegoria do instante revolucionário e da interrupção que ele instaura no tempo do progresso. Com a destruição da linearidade como primeiro passo rumo a uma estrutura constelar da história, o leitor de Benjamin reiteradamente é confrontado com o topos da interrupção e seus similares, tais como a imobilização, a cristalização, o salto, o relâmpago e o choque. No caso do relâmpago caberia lembrar que ele comporta também um aspecto construtivo, uma vez que implica a tradicional ideia da luz enquanto metáfora do conhecimento. Do ato inicial destrutivo, gerado pelo raio, resultam as ruínas, os escombros, os fragmentos e até mesmo os farrapos e detritos. Até mesmo o conceito de imagem dialética, que utilizamos ao longo desta dissertação, é tributário do conceito de "relâmpago". Segundo Benjamin, "imagem dialética é aquilo onde, à maneira de um relâmpago, o acontecido se une ao agora numa constelação." (BENJAMIN, 2006: 576). A distância temporal se transforma na simultaneidade da imagem que, enquanto constelação, possui não apenas a terceira dimensão da profundidade, mas, devido às imensas distâncias do universo, a quarta dimensão do tempo-espaço. Da mesma maneira que estrelas já extintas se apresentam ao olho do observador, o passado, geralmente dado por perdido, se manifesta, mesmo que relampejando, ao historiador atento. A partir dessa perspectiva, a tentativa do anjo da história de "acordar os mortos", não pode ser vista como uma ação impossível.
}

${ }^{99}$ Gunther Anders, em seu livro Kafka: Pró e contra. Os autos do processo, explora as relações que permeiam "esse engano mundial" nas relações entre a aparente loucura e falta de nexo do universo kafkiano e suas possíveis conexões com a realidade. Aponta o autor: "Aqui entramos em Kafka. A fisionomia do mundo kafkiano parece desloucada. Mas Kafka deslouca a aparência aparentemente normal do nosso mundo louco, para tornar visível sua loucura. Manipula, contudo, essa aparência louca como algo muito normal e, com isso, descreve até mesmo o fato louco de que o mundo seja considerado normal." (ANDERS, 1993: 63). 
corpo melancólico em um tempo que se deseja tanto mítico quanto político, segundo a correspondência entre Scholem e Benjamin ${ }^{100}$.

Podemos traçar uma correspondência entre esse vazio e o tédio, do qual nos fala Benjamin. Em seu ensaio $O$ narrador, o autor nos diz que "o tédio é o pássaro onírico que choca os ovos da experiência." (BENJAMIN, 2012c: 221). O tédio pode ser visto como sintoma e potência melancólica: ele é, ao mesmo tempo, a manifestação da consciência da insignificância das nossas relações no mundo e da ausência de razões para nossa ação nesse mundo, quanto, contraditoriamente, é um estado de esvaziamento tão profundo que disponibiliza este corpo à experiência, a uma trajetória autêntica. Onde nada parece acontecer de verdadeiramente significativo e legítimo, é de onde pode surgir algo que nos valha à pena, o próprio ato criativo, a experiência, enfim. $\mathrm{O}$ tédio, qualidade contrária ao nosso automatismo maquinal e produtivo cotidiano, confere um certo espaço aberto para nossas ações e pensamentos. Não por acaso, o estado tedioso, no qual os minutos se desenrolam lentamente, foi muito utilizado no processo de criação de Anatomia da melancolia - experiência I. Os movimentos surgiam da total imobilidade tediosa de meu corpo e desse tédio, desse completo vazio, da insignificância que o mundo à minha volta e nosso contexto social me pareciam revelar. Então uma reação de meu corpo aparecia, reação que eu poderia entender tanto como contestação desse próprio vazio de origem, quanto como uma correspondência ao contexto

\footnotetext{
${ }^{100}$ Importante recordarmos aqui a concepção de mito, de sagrado e de teologia de que estamos partindo, ao lado de Benjamin. Como diria Scholem, a respeito do amigo: "Temos aqui a descrição de um pensamento que absorveu a tal ponto os ensinamentos da teologia que o texto sagrado original torna-se dispensável. Como se a tinta da primeira página tivesse sido totalmente apagada e só ficasse para nós a constelação de manchas e sinais, constelação que, segundo a analogia de Benjamin, deveria ser suficiente, sem possibilidade de volta ao texto primitivo." (SCHOLEM, 2003: 99).
} 
das nossas relações sociais. Desse modo nasceu a primeira cena deste solo e que disparou o restante da criação e da sequência dramatúrgica.

Este vazio é visto aqui como potência criativa que nos liberta como um "pássaro onírico" que nos abre espaço à experiência. De outro lado, esse vazio carrega em si uma qualidade de anulação do próprio corpo, de negação absoluta de seu sentido, aura e valor, posto que ele já se tornou mercadoria. $\mathrm{O}$ corpo opera assim a partir de sua própria morte, de sua paralisia e inércia, de seu deserto subjetivo: só lhe é possível existir a partir de rupturas, de um movimento de negação da própria vida e de seu fluxo, negação essa fundadora de uma corporeidade da ausência. Aqui reside a dramaturgia contraditória do corpo melancólico de Anatomia da Melancolia - Experiência I, dada que sua linguagem (sua ação no mundo) advém de sua própria negação, da anulação dessa mesma linguagem, engajando este corpo em um processo de contradição interna.

Essa contradição pode ser exemplificada e refletida a partir do personagem Fausto de Goethe, quando esse se justifica (Fausto II, v. 6231-6256) diante de Mefistófeles, ao dizer, antes de descer ao Reino das Mães:

Não andei eu pelo mundo a conhecê-lo?

A aprender o Vazio e a ensiná-lo?

E se ao que vi dei a voz da razão,

Mais alto ecoava a contradição;

Fugindo aos golpes baixos que apanhei,

Para erma solidão me retirei,

E p'ra não ficar só, ao fim e ao cabo

Acabei mesmo por me entregar ao diabo. (...)

A vazio me confias, 
Pra aí revigorar arte e energias:

Como ao tal gato me usas, é o costume,

P'ra que eu te vire as castanhas do lume.

Pois sejas então! Vamos até ao fundo,

Que no teu Nada espero encontrar o Todo. (GOETHE, 2003: 316)

O diabo é a própria negação que Goethe personifica em Mefistófeles. (Segundo sua própria autodefinição: "Eu sou o espírito que só sabe negar/ E com razão: tudo o que nasce e vês/ É digno apenas de morrer outra vez." (GOETHE, 2003: 89). Diante da experiência decepcionante de Fausto, o que fazer? Um dispositivo para este corpo melancólico seria: aprofundar o vazio e desta "falta" extrair sua linguagem, a aura deste vazio.

Escutar o vazio, o nada do corpo melancólico, é escutar o outro eu que o habita, seu negativo, seu "contrário", assim como é em Mefistófeles, símbolo máximo da negação (o diabo, o outro) que Fausto encontra o Todo, o eu. Essa contradição intrínseca à hipermodernidade e ao corpo melancólico pode ficar ainda mais clara a partir desta passagem de Terry Eagleton (2003: 330) em seu Doce Violência, a ideia do trágico: "A modernidade é tanto democracia política quanto guerra global, a possibilidade do feminismo e a degradante realidade das mulheres (...). Tudo em uma situação como esta, comenta Marx, parece sugerir seu oposto.". Prossegue Eagleton mencionando que, "fontes de riqueza são transformadas em carência, tecnologias que poderiam emancipar o trabalho humano acabam por esmagá-lo até que se esgote, e, por alguma misteriosa lógica, a liberdade desvirtua-se e se transforma em 
dominação.”(Idem) ${ }^{101}$. Para Eagleton, “em uma emocionante peça de teatro político, a modernidade derrota um Estado absolutista após o outro e, em seguida, instala em seu lugar a tirania do capital." (Idem). Assim, modernidade capitalista seria, de fato, "uma Queda; mas, como todas as Quedas mais interessantes, ela foi uma queda para cima, em vez de ser uma queda para baixo, uma liberação de energia humana que também representou seu próprio confinamento." (Ibidem: 331). Expressando a dualidade contraditória que baseia nossa análise sobre a melancolia, Eagleton afirma que o Fausto de Goethe "É uma demonstração da incestuosa intimidade do mortífero e da melhoria de vida, e o mito que codifica essa dualidade da maneira mais assombrosa para o período moderno é a fábula de Fausto. O pacto com Mefistófoles é o preço que pagamos pelo progresso." (Idem).

Fausto reconhece as contradições de sua subjetividade: ao vender a alma ao diabo - seu duplo estranho - pode dialeticamente negá-lo e conhecer a si mesmo: o Todo, que, longe de ser uma síntese harmônica, idealista, una e uniforme, resulta desta contradição dialética, caracterizando-se por forças contraditórias em choque e em suspensão. É neste nada, no vazio do corpo melancólico, que ressoa o trauma que o petrifica; escutá-lo é libertá-lo - é encontrar o Todo que nos diz Fausto -, trazendo de volta seu movimento, sua resistência, e, no limite, uma

\footnotetext{
${ }^{101}$ Encontramos essa ideia de Marx claramente formulada no seguinte texto: "Por um lado, despontaram para a vida forças industriais e científicas, de que nenhuma época da história humana anterior alguma vez tinha suspeitado. Por outro lado, existem sintomas de decadência que ultrapassam de longe os horrores registrados nos últimos tempos do Império Romano. Nos nossos dias, tudo parece prenhe do seu contrário. Observamos que maquinaria dotada do maravilhoso poder de encurtar e de fazer frutificar o trabalho humano o leva à fome e a um excesso de trabalho. As novas fontes de riqueza transformam-se, por estranho e misterioso encantamento, em fontes de carência. Os triunfos da arte parecem ser comprados à custa da perda do carácter. Ao mesmo ritmo que a humanidade domina a natureza, o homem parece tornar-se escravo de outros homens ou da sua própria infâmia.” (MARX,1971: 546)
} 
reflexão em relação ao seu processo de formação, necessariamente, um processo também histórico. Este outro se instaura no choque de seu passado com seu presente: é o eco da liberdade perdido no espaço homogêneo e perverso do progresso. ${ }^{102}$

\section{CORRESPONDÊNCIAS}

No poema Correspondances, Baudelaire recorre ao "eco" como índice tanto das correspondências entre as imagens do passado e do presente quanto da sobrevivência de sua origem: "Como os longos ecos que ao longe se confundem" 103 (BAUDELAIRE, 2002: 17). A melancolia, tal como o eco de um estranho eu, esse outro eu negativo nosso avesso repugnante -, é a manifestação corporificada de um malestar social, o vestígio de que "as coisas não vão bem", eco do trauma moderno:

Diferentemente do reflexo que produz uma imagem em sua integridade à maneira de um espelho, o eco é uma espécie de vestígio sonoro que, mesmo sendo apenas um traço parcial de sua origem, pode garantir a sobrevivência da mesma (...), capaz de estabelecer uma ligação com uma origem remota, superando, pelo menos por um momento, uma grande distância. (OTTE, 2012: 82)

\footnotetext{
102 "Para Schopenhauer, o regozijo em relação à tragédia surge quando nos desligamos do mundo e renunciamos à vontade de viver. Há um melancólico tipo de prazer a ser obtido do reconhecimento de que o mundo e a vontade não podem nos conceder nenhuma satisfação absoluta e portanto, não vale a pena nos apegarmos a eles. Essa é a alegria de uma liberdade plena, que se sabe invulnerável porque, como os depressivos e os melancólicos, abandonou todo o investimento na realidade." (EAGLETON, 2013: 242).

${ }^{103}$ No original: "Comme de longs échos qui de loin se confondent.".
} 
Como vimos ao longo desta dissertação, o objeto perdido só pode ser recuperado por meio da permanência de seus ecos. O melancólico seria o próprio sujeito da repressão que, tal como um eco perdido, participa da constituição subjetiva do eu, diferentemente do objeto concreto que foi perdido no luto.

Estes ecos e lacunas também marcam a qualidade de movimento do corpo melancólico em Anatomia da melancolia - experiência I. A temporalidade dramatúrgica do movimento - início, desenvolvimento e fim de um gesto ou deslocamento - é composta de suspensões, rupturas, atenta para as faltas (vazios), rupturas, contradições e fracassos históricos, tornando invisíveis as vozes oprimidas que interrompem o fluxo da história. Diante de uma história cheia de fissuras e ruínas sociais, de traumas generalizados, não parece ser possível criar uma narrativa linear do movimento, suprimindo seus vazios internos. No contexto da corporeidade melancólica, não parece ser possível constituir um "fluxo" contínuo e sem rupturas do movimento, daí o caráter fragmentário e alegórico do corpo em Anatomia da Melancolia experiência I.

Contrária ao historicismo e ao fluxo sem contradição, a temporalidade dramatúrgica desse corpo melancólico se constrói a partir do vazio traumático, de nossa história devastada e hipermoderna, de cujas lacunas emerge o negativo da história dos vencedores: é sob esta terra arrasada que podemos escutar os sussurros deste passado que é ainda presente, da tradição para Benjamin. Os vazios, suspensões e a apneia do corpo, em Anatomia da Melancolia - experiência I, são expressões de um panorama histórico também destroçado, sufocante e arruinado. 
Essa corporeidade da ausência se relaciona diretamente com a ausência objetiva de uma história não-oficial em nossa própria formação: a história brasileira que é um corpo "ausente", que desconhecemos, se pensarmos na história do Brasil antes de se tornar colônia, antes de se tornar uma mercadoria da metrópole, antes de se tornar pau-brasil. Nossa história parece ter sido exterminada e solapada pelo progresso civilizatório. Talvez ainda mais cruel que no caso europeu, o Brasil herda a forma democrática liberal sendo um país escravocrata, sem, no entanto, ter sofrido o processo revolucionário industrial, em uma espécie de Deus ex machina, cujo Deus brasileiro é o liberalismo autocrata e a máquina são nossos próprios corpos solapados por esse novo Deus furioso e impiedoso. Segundo Francisco Oliveira, trata-se da exceção permanente do dia-a-dia brasileiro, marcada pela "subordinação da nova classe social urbana, o proletariado, ao Estado, e pelo 'transformismo brasileiro', forma de modernização conservadora, ou de uma revolução produtiva sem revolução burguesa." (OLIVEIRA, 2003: 131). Para o sociólogo brasileiro, o aspecto de nossa formação histórica ter vivido uma revolução produtiva sem uma revolução burguesa, democrática, revela "o caráter produtivo do atraso como condômino da expansão capitalista. Como disse Walter Benjamin, os oprimidos sabem do que se trata." (Idem). Adaptando os conceitos de Benjamin para a realidade brasileira, Oliveira afirma que: "o subdesenvolvimento é a exceção sobre os oprimidos: o mutirão é a autoconstrução como exceção da cidade, o trabalho informal como exceção da mercadoria, o patrimonialismo como exceção da concorrência entre os capitais." (Idem).

Trata-se, no nosso caso, da formação histórica de um massacre subjetivo e cultural a olhos nus, não metafórico: populações indígenas exterminadas, homens-máquina-mercadoria-escravos comprados e, em 
seguida, igualmente exterminados, trabalhadores-máquina-mercadoriaperiféricos mortos de fome ou tiro, destituídos de proteção e justiça legal. Aqui tudo se compra, tudo se vende, tudo se mata e se põe outro no lugar. Diante dessa paisagem de miséria subjetiva asfixiante, qual seria a trajetória utópica que poderia engajar certa esperança? Qual dramaturgia emerge daí? Parece ser essa a indagação principal que mobiliza os deslocamentos e fluxos energéticos deste corpo melancólico nesta dissertação e em Anatomia da melancolia - experiência I.

Se nosso trauma hipermoderno soterra o acesso à linguagem, qual a possibilidade dramatúrgica, senão uma que leve em conta um espaço de liminaridade do vazio particular deste corpo melancólico e do vazio social de uma comunidade humana? Procurei entender qual linguagem poderia advir desse vazio, justamente, desta ausência de experiência, de seu negativo, de sua ruína e destruição (da própria anulação do corpo), absorvendo-as como dispositivos de trabalho e de criação de uma corporeidade da ausência. Para este corpo melancólico é a própria linguagem que foi esquecida, ou seja, é o próprio sujeito - o próprio corpo - que não se encontra em parte alguma e cuja memória foi dizimada diante dos traumas de nossa época. Este corpo ausente, apagado de si mesmo, não lembra ou ainda, não "compreende", o que deve acionar para se levantar de uma cadeira e se colocar de pé (fazendo referência à primeira cena de Anatomia da melancolia - experiência I, por exemplo). A coerência racional e cinética foi esquecida, o sentido e a direção de sua racionalidade foi destruída por bombas atômicas, massacres e violências econômicas e sociais cotidianas.

A melancolia seria tanto um estado quanto uma ação de desvio, um reflexo "desviado", torto, turvo, editado, subjetivo - porque em experiência -, tornando-se estratégia de reflexão e material para uma 
linguagem político-estética, físico-poética deste corpo diante de seu trauma civilizatório hipermoderno. A contradição entre um corpo que tanto contempla sua época, quanto nela cria rupturas, é a base motriz dessa corporeidade, constituída de contradições hiperbólicas, extremadas, cujas ações se dão no limiar não fusional "do quente e do frio, da inquietação e da paralisia, da exaltação e do abatimento, tristeza estéril e meditação fecunda, prostração do vazio e plenitude do saber.” (STAROBINSKI, 2014: 45). Uma linguagem que pode ser compreendida como um reflexo polifônico de nossa cisão subjetiva e que se manifesta na fisicalidade dramatúrgica desse corpo. Segundo Julia Kristeva (1990: $44-45)$ :

[A melancolia] deriva do guincho da cigarra no silêncio da noite. Um ruído que perturba a paz interior que precisamos para dormir. Essa etimologia curiosa subjaz à dupla qualidade de desfalecimento e força criativa que os românticos dão à melancolia ou spleen. "Encontrei a definição de beleza" escreve em 1877 Baudelaire em seu diário, "É alguma coisa ardente e aflita (...) voluptuosa e triste, que abre caminho para a melancolia, a lassidão e mesmo a saciedade" (...) Esse estado anímico é uma linguagem?

Uma corporeidade da ausência ${ }^{104}$ supõe uma linguagem dialética no limiar da contemplação e da perfuração, dinâmica familiar ao estado

\footnotetext{
${ }^{104} \mathrm{Um}$ dos grandes poemas melancólicos da história da literatura brasileira partiu desse "guincho das cigarras", mencionado por Kristeva, para configurar sua imagem dialética central. É o poema "Aceitação", de Cecília Meireles:

"É mais fácil pousar o ouvido nas nuvens

e sentir passar as estrelas

do que prendê-lo à terra e alcançar o rumor dos teus passos.

É mais fácil, também, debruçar os olhos no oceano

e assistir, lá no fundo, ao nascimento mudo das formas,
} 
melancólico constituído dessa "dupla qualidade de desfalecimento e força criativa", de "alguma coisa ardente e aflita (...) voluptuosa e triste (...)". Como citado anteriormente, essas mesmas contradições estão presentes na relação negativa entre Fausto e Mefistófoles. Na obra de Goethe, o Todo, como diz Fausto, viria da experiência com o estranho, com o desconhecido, com aquilo sobre o quê não temos domínio, com o inefável, com aquilo que não se torna propriedade: este é o sujeito objeto faltante - ao melancólico. A felicidade autêntica refere-se à experiência que foi esquecida, tornando-se estranha (unheimlich). Esse corpo que se desloca a partir de choques dialéticos cria uma espécie de síncope espaço-temporal que abre sua experiência ao seu desconhecido, seu outro de si mesmo: seu duplo utópico que se forma do choque e da luta hiperbólica entre passado-presente-futuro: um corpo que rompe e irrompe do continuum da história, recuperando o trauma como esse estranho familiar que ilumina o "Agora" para uma esperança revolucionária:

[...] a história de Fausto refere-se ao fato de que as raízes de nossa criatividade são putrefatas - que a civilização está enraizada na barbárie da exploração, que a cultura precisa submeter o instinto de morte ao seu serviço, que a memória exige o oblívio, que debaixo do valor e do significado repousa a materialidade sem sentido, não significativa, da Natureza, o corpo e os impulsos inconscientes. (EAGLETON, 2003: 331)

que desejar que apareças, criando com teu simples gesto

o sinal de uma eterna esperança.

Não me interessam mais nem as estrelas, nem as formas do mar, nem tu.

Desenrolei de dentro do tempo a minha canção:

não tenho inveja às cigarras: também vou morrer de cantar.” (MEIRELES, 2005: 45) 
Nossa melancolia social hipermoderna se caracteriza por uma ausência, por esse instinto de morte sob o qual, no entanto, está a materialidade de impulsos - choques - inconscientes com os quais é preciso realizar um trabalho de "rememoração", a partir da experiência mesma com o vazio "não significativo" do corpo, da natureza. Foi essa a experiência que busquei durante o processo de criação de Anatomia da melancolia - experiência I. Um trabalho sobre esse vazio poderia fazer emergir novamente o trauma, nos traria os choques não só para que rememorássemos nosso passado - e não o esquecêssemos -, mas ainda, em vista de sua tradução em uma linguagem, em uma corporeidade da ausência fundada no resgate da potência subversiva e de resistência deste corpo diante de sua história individual e coletiva.

\section{ULTIMÍSSIMO DIA}

O horizonte desse vazio, longe de ser o de uma anulação absoluta da linguagem, é, ao contrário, o da potência de sobrevivência e de contestação que esta corporeidade da ausência parece mobilizar, corporeidade na qual o Outrora e o Agora se chocam em uma imagem dialética que abre espaço para a criação de um tempo messiânico cujo passado (embora seja ele nossa origem), contraditoriamente, está para chegar (como "o messias", cuja presença se faz dada sua própria ausência); passado que está para ser escrito em um tempo do Agora Jetztzeit - benjaminiano. "O Messias não virá até que já não seja necessário, e mais, chegará depois de sua própria vinda, não virá no último dia, senão no dia posterior ao último, no ultimíssimo dia." (KAFKA, 2003: 621-623). A linguagem que nasce desse corpo 
melancólico parece estar impregnada da bile negra desse ultimíssimo dia. Trata-se de um corpo que chegaria "depois de sua própria vinda", vivendo nos limiares históricos, movendo-se em uma espécie de “corporeidade ultimíssima".

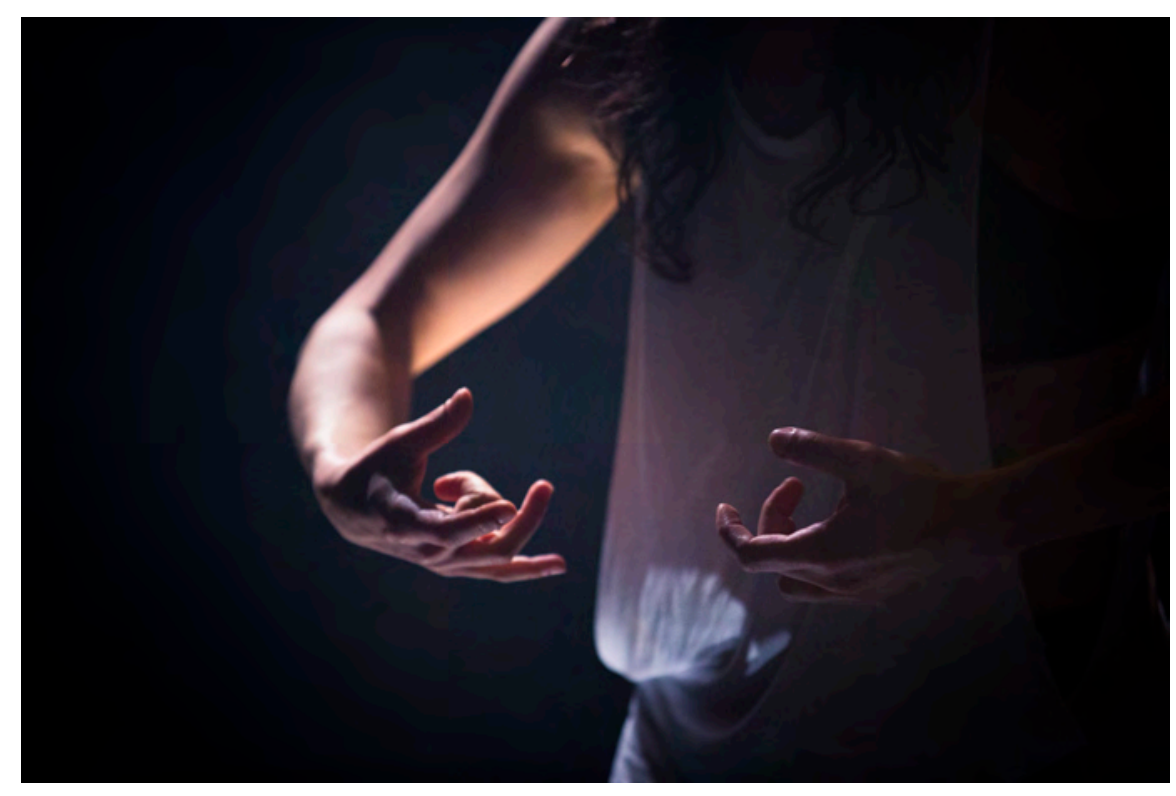

Imagem 8. APREENDER O INVISÍVEL. Anatomia da melancolia experiência I.

Foto: Otávio Dantas. 


\section{REFERÊNCIAS BIBLIOGRÁFICAS}

ADORNO, Theodor. Prismas: crítica cultural e sociedade. São Paulo: Ática, 1998.

. Indústria cultural e sociedade. São Paulo: Paz e Terra, 2002.

. Teoria estética. Madrid: Akal, 2004.

. Notas de literatura I. São Paulo: Editora 34, 2007.

. Minima Moralia: reflexões a partir da vida lesada. (G. Cohn, Trad.). Rio de Janeiro: Beco do Azougue, 2008.

. Dialética negativa. Rio de Janeiro: Zahar, 2010.

. Teoria Estética. Lisboa: Edições 70, 2012.

ADORNO, T.W.; HORKHEIMER, M. Dialética do esclarecimento. Rio de Janeiro: Zahar, 2006.

AGAMBEN, Giorgio. Infância e História. Destruição da Experiência e Origem da História. Belo Horizonte: UFMG, 2008. 2009.

. O que é o contemporâneo? e outros ensaios. Chapecó: Argos, . Nudez. Lisboa: Relógio D’Água, 2010.

. Estâncias: a Palavra e o Fantasma na Cultura Ocidental. Belo Horizonte: UFMG, 2012a.

. Ideia da prosa. Belo Horizonte: E. Autêntica, 2012b.

. O Homem sem conteúdo. Belo Horizonte: Autêntica. 2012c.

ALEKSIÉVITCH, Svetlana. Vozes de tchernóbil. São Paulo: Cia das Letras. 2016.

ANDERS, Gunther. Kafka: pró e contra - os autos do processo. São Paulo: Perspectiva, 1993.

ARENDT, Hanna. Entre o Passado e o Futuro. São Paulo: Perspectiva, 2013.

ARISTÓTELES. Metafísica. Tradução de Marcelo Perine. São Paulo: Edições Loyola, 2002.

BADIOU, Alain. A República de Platão Recontada por Alain Badiou. Rio de Janeiro: Zahar. 2014. 
BAUDELAIRE, Charles. Sobre a modernidade. São Paulo: Paz e Terra, 1996.

. Obra completa. Rio de Janeiro: Aguilar, 1997.

.Les Fleurs du Mal. Paris: Librio, 2002.

. Le Musée Classique du Bazar Bonne-Nouvelle. In: Baudelaire:

Oeuvres Complètes, Vol.II. Paris: Ed. Gallimard, 2004.

. O Pintor da Vida Moderna. São Paulo: Autêntica, 2012.

BAUDRILlard, Jean. A Troca Simbólica e a Morte. São Paulo: Loyola, 1996.

BENJAMIN, Walter. A modernidade. Lisboa: Assírio \& Alvim, 2006.

A obra de arte na época de sua reprodutibilidade técnica. Porto Alegre: L\&PM, 2013c.

. As passagens. São Paulo/Belo Horizonte: Edusp/UFMG, 2006.

. Charles Baudelaire, um lírico no auge do capitalismo. Obras completas III. Rio de Janeiro: Brasiliense, 2000.

. Imagens de pensamento. Lisboa: Assírio \& Alvim, 2004.

. Frans Kafka. No décimo aniversário de sua morte. In: Ensaios sobre literatura. Lisboa: Assírio \& Alvim, 2016.

$\overline{2013 d .}$

Escritos sobre mito e linguagem. São Paulo: Editora 34, $\overline{2012 c .}$

Magia e Técnica, Arte e Política. São Paulo: Brasiliense,

. Fragmento teológico-político. In: Obras completas II/1. Madrid: Abada, 2010.

Sobre o conceito de História. In: O Anjo da História. São Paulo: Autêntica, 2012b.

. Experiência e Pobreza. In: O Anjo da História. São Paulo: Autêntica, 2013a.

. Origem do Drama Trágico Alemão. Belo Horizonte: Autêntica. 2013b.

Éditions du Cerf, 1989.

. Paris, capital du XIX siècle. Le Livre des Passages. Paris: Les . Rua de mão única. São Paulo: Brasiliense. 2012a. 
BENJAMIN, Walter e SCHOLEM, Gershom. Correspondência. São Paulo: Perspectiva. 1993.

BENTLEY, Eric. O Teatro Engajado. Rio de Janeiro: Zahar. 1969.

BERLINCK, Luciana Chaui. Melancolia: rastros de dor e perda. São Paulo: Ed. Humanitas FFLCH/ USP, 2009.

BERMAN, Marshall. Tudo o que é sólido desmancha no ar. A aventura da modernidade. São Paulo: Cia das Letras, 2014.

BLIN, Richard. Corps et âmes: la vie à l'oeuvre. Artigo publicado na revista francesa Magazine Littéraire. Paris, p. 30-40, set. 1990.

BLOCH, Ernst. O princípio esperança, vol. I. Rio de Janeiro: EdUERJ: Contraponto, 2005.

BOTELHO, Letícia. Walter Benjamin e as imagens da história: possibilidades de uma crítica social a partir da arte. Pólemos, Brasília, v. 1, n. 1, mai. 2012.

BOURDIEU, Pierre. A Miséria do Mundo. São Paulo: Vozes, 1997.

. Questões de Sociologia. Lisboa: Fim de Século, 2003.

BOURETZ, Pierre. Testemunhas do Futuro. Filosofia e Messianismo. São Paulo: Perspectiva, 2011.

BRUSTEIN, Robert. O Teatro de Protesto. Rio de Janeiro: Zahar, 1967. BUCCI, Eugênio. Informação e guerra a serviço do espetáculo. In: A imprensa e o dever da liberdade. São Paulo: Contexto, 2009 .

BUCK-MORSS, Susan. Walter Benjamin, escritor revolucionário. Buenos Aires: Interzona Editora, 2005.

BURTON, Robert. Anatomia da Melancolia, vols. 1, 2, 3 e 4. Guilherme Gontijo Flores (Trad.). Paraná: UFPR, 2011.

CAMUS, Albert. O Homem Revoltado. Rio de Janeiro: Record, 1996.

CALVINO, Italo. Seis propostas para o próximo milênio. São Paulo: Cia. das Letras, 2015.

CANDIDO, Antonio. Literatura e sociedade. São Paulo: Ouro sobre Azul, 2012.

CANTINHO, Maria João. O voo suspenso do tempo: estudo sobre o conceito de imagem dialéctica na obra de Walter Benjamin. Espéculo Revista de estudios literários. Madrid, Universidad Complutense de Madrid, 2008. 
Walter Benjamin e a história messiânica contra a visão histórica do progresso. Philosophica, Lisboa, n. 37, p. 177-195, 2011.

A teia de Penélope e o anel da tradição. Blog Maria João

Cantinho, 30 jul. $2015 . \quad$ Disponível em: $<$ http://mjcantinho.com/2015/07/30/a-teia-de-penelope-e-o-anel-datradicao/>. Acesso em: 3 de jan. 2016.

CARERI, Francesco. Anti-Walk. Walkscapes: o caminhar como prática estética. São Paulo: Ed. G.Gili, 2013.

CARLSON, Marvin. Performance - uma introdução crítica. Trad. Thais Flores Nogueira Diniz e Maria Antonieta Pereira. Belo Horizonte: Ed. UFMG, 2010.

CERTEAU, Michel de. Caminhadas pela cidade. A Invenção do Cotidiano I. Artes de Fazer. Petrópolis: Vozes, 2009, 16 ${ }^{\text {a }}$ Ed.

CHESterton, G. K. A candura do Padre Brown. In: Obras completas II. Barcelona: Plaza \& Janes, 1968.

COHEN, Renato. Performance como linguagem. São Paulo: Perspectiva, 1989.

CRARY, Jonathan. Suspensões da percepção: atenção, espetáculo e cultura moderna. Trad. Tina Montenegro. São Paulo: Cosac Naify, 2013.

DARDOT, Pierre; LAVAL, Christian. A nova razão do mundo. Ensaio sobre a sociedade neoliberal. São Paulo: Boitempo, 2016.

DEACON, Roger \& PARKER, Ben. Educação como Sujeição e como Recusa. In: O Sujeito da Educação - Estudos Foucaultianos (org. Tomaz Tadeu da Silva). Petrópolis: Vozes, 2002.

DEBORD, Guy. La Société du Spectacle. Paris: Gallimard, 1993.

DELGADO, Manuel. Artivismo y pospolítica: sobre la estetización de las luchas sociales en contextos urbanos (conferência). In: Festival Internacional de Teatro de Brasília: Cena Contemporânea, 2013.

DERRIDA, Jaques. A Farmácia de Platão. São Paulo: Iluminuras, 2005.

DIDEROT, Denis. Ensaios sobre a Pintura. Campinas: Ed. Unicamp, 1993.

DIDI-HUBERMAN, George. Ante el tiempo. Buenos Aires: Adriana Hidalgo, 2014. 
2011.

Atlas ou le gai savoir inquiet. Paris: Les Éditions de Minuit,

. Diante da Imagem. São Paulo: Editora 34, 2015.

2013.

. Quelle émotion! Quelle émotion? Montrouge: Ed. Bayard, 2012.

. Supervivencia de las luciérnagas. Madri: Abada Editores,

DIÉGUEZ, I. Escenarios y teatralidades liminales: prácticas artísticas y socioestéticas. Archivo virtual Artes Escénicas, 2009. Disponível em: $\langle$ http://artesescenicas.uclm.es/index.php?sec=texto\&id=205>. Acesso em: 15 mar. 2015.

EAGLETON, Terry. As ilusões do pós-modernismo. Rio de Janeiro: Zahar, 2003.

. Doce Violência - A ideia do trágico. São Paulo: Unesp, 2012.

FABIÃO, Eleonora. Performance e Teatro: poéticas e políticas da cena contemporânea. In: Revista Sala Preta. São Paulo, n. 8, 2008.

FÉRAL, J. Pratiques Performatives. Body Remix. Québec, Canada: Presse de l'université du Québec e de Rennes, 2012.

Perspectiva, 2015.

. Além dos limites: teoria e prática do teatro. São Paulo:

FOSTER, Hal. O retorno do real. Revista Concinnitas. Rio de Janeiro, ano 6, v. 1, n. 8, jul. 2005.

FOUCAULT, Michel. Os anormais. São Paulo: Martins Fontes, 2001.

FREUD, Sigmund. A Negação. São Paulo: Cosac Naify, 2014.

. Luto e Melancolia. São Paulo: Cosac Naify, 2011.

. O Mal-estar na civilização, novas conferências introdutórias

à psicanálise e outros textos (1930-1936). Obras completas. V. 18. São Paulo: Cia. das Letras, 2010.

GAGNEBIN, Jeanne Marie. Lembrar Escrever Esquecer. São Paulo: Editora 34, 2009.

Apagar os rastros, Recolher os restos. In: Walter Benjamin -

Rastro, aura e história (GINZBURG, Jaime; SEDLMAYER, Sabrina Orgs.). Belo Horizonte: Editora UFMG, 2012, p. 27-38.

GUINSBURG, J. e FERNANDES, Sílvia (Orgs). O Pós-dramático. São 
Paulo: Perspectiva, 2009.

GANEBIN, Jeanne Marie. Lembrar escrever esquecer. São Paulo: Editora 34, 2009.

. Limiar, aura e rememoração. São Paulo: Editora 34, 2014.

GASSNER, John. Rumos do Teatro Moderno. Rio de Janeiro: Lidador, 1965.

GOETHE, J.W. [Urfaust] Fausto Zero. São Paulo: Cosac \& Naify, 2001. . Fausto. João Barrento (Trad.). Lisboa: Assírio \& Alvim, 2003. . As afinidades eletivas. São Paulo: Companhia das letras, 2015.

GLUSBERG, Jorge. A Arte da Performance. São Paulo: Perspectiva, 2001.

GOTTFRIED, Martin. Teatro Dividido. Rio de Janeiro: Bloch. 1970.

HEGEL, G.W.F. Lecciones sobre la historia de la filosofia II. Buenos Aires: FCE, 1955.

Enciclopédia das ciências filosóficas em compêndio: a ciência da lógica. São Paulo: Loyola, 1995.

JACQUES, Paola Berenstein. Corpocidade. Salvador: EDUFBA, 2010.

. Elogio aos errantes: a arte de se perder na cidade. Salvador: EDUFBA, 2006.

KAFKA, Franz. Diários. Madrid: De Bolsillo, 1999.

das Letras, 1997.

O processo. Modesto Carone (Trad.). São Paulo: Companhia . Obras completas III. Galaxia Gutenberg, 2003.

KEHL, Maria Rita. O Tempo e o Cão. São Paulo: Boitempo, 2009.

KRISTEVA, Julia. L'Infigurable mélancolie. In: Magazine Littéraire. Paris, Setembro, 1990, p. 43-44.

1987.

Soleil Noir, dépression et mélancolie. Paris: Ed. Gallimard,

LAGES, Susana Kampff. Tradução e Melancolia. São Paulo: EDUSP, 2007.

LARROSSA, Jorge. A Operação ensaio: sobre o ensaiar e o ensaiar-se no pensamento, na escrita e na vida. Educação \& Realidade. V. 29. Porto Alegre, 2004. 
LEHMANN, Hans-Thies. Teatro pós-dramático. Pedro Sussekind (Trad.). São Paulo: Cosac Naify, 2007.

LEME, Viviane Maria. A concepção de tragédia moderna em The crucible e $A$ view from the bridge de Artur Miller. São Paulo, SP, Dissertação (Mestrado), Faculdade de Filosofia Letras e Ciências Humanas, USP: 2007, 147 p.

LIPOVETSKY, Gilles. A felicidade paradoxal. Ensaio sobre a sociedade de hiperconsumo. São Paulo: Cia. das Letras, 2007.

. com Sébastien Charles. Os Tempos Hipermodernos. São Paulo: Barcarolla, 2004.

LÖWY, Michel; SAYRE, Robert. Rebelión y Melancolia - El romantismo como contracorriente de la modernidad. Buenos Aires: Ed. Nueva Visión, 2008.

LÖWY, Michel. Walter Benjamin: Aviso de Incêndio. São Paulo: Boitempo, 2005.

MARTINS, Luiz Renato. Revoluções, Poesia do Inacabado 1789-1848. São Paulo: Sundermann, 2014.

O hemiciclo: imagem da forma-Nação. In: Revista Crítica Marxista, São Paulo, n. 29, 2009.

MARX, Karl. Discurso no Aniversário de “The People's Paper" (1856). In: Obras escolhidas. Lisboa: Avante, 1971.

. Manuscritos econômico-filosóficos. Jesus Ranieri (Trad.). São Paulo: Boitempo, 2004.

O Capital, Livro III. São Paulo: Boitempo, 2017.

MARX, Karl; ENGELS, Friedrich. O manifesto comunista. São Paulo: Boitempo, 1998.

MATOS, Ivan Delmanto F. A dramaturgia negativa: dialética trágica e formação do teatro brasileiro. São Paulo, SP, Tese (Doutorado), Escola de Comunicações e Artes, Universidade de São Paulo: 2016.

MEDEIROS, Maria Beatriz. Arte, Performance e Rua. In: Revista Artefilosofia, Ouro Preto, Universidade Federal de Ouro Preto, n. 12, 2012.

MEIRELES, Cecília. Poesia completa em dois volumes. Rio de Janeiro: Nova Fronteira, 2005.

MERLEAU-PONTY, Maurice. Fenomenologia da percepção. Carlos 
Alberto de Ribeiro Moura (Trad.). São Paulo: Martins Fontes, 2006.

MONTAIGNE, Michel de. De Demócrito e Heráclito. In: Ensayos. Barcelona: Galaxia Gutenberg, 2011.

NIEL, Leone. Atlas Mnemosine. A regra e a excepção (blog), 8 dez.

$2011 . \quad$ Disponível

em:

$<$ http://aregraeaexcepcao.blogspot.com.br/2011/12/atlas-

mnemosine.html>. Acesso em: 25 jul. 2017.

NIETZSCHE, Friedrich. Verdade e Mentira no sentido extra-moral. Coleção Os Pensadores. São Paulo: Ed. Nova Cultural, 1999.

Segunda consideração intempestiva. Das vantagens e dos

Inconvenientes da História para a Vida. Rio de Janeiro: Relume Dumará, 2003.

OEHLER, Dolf. Quadros Parisienses. São Paulo: Cia. das Letras, 1997. 1999.

O velho mundo desce aos infernos. São Paulo: Cia. Das Letras, . Terrenos Vulcânicos. São Paulo: Cosac \& Naif, 2004.

OLIVEIRA, Francisco. Crítica da Razão Dualista e O Ornitorrinco. São Paulo: Boitempo, 2003.

OTTE, George. Vestígios da experiência e índices da modernidade. In: Walter Benjamin - Rastro, aura e história (SEDLMAYER, Sabrina; GINZBURG, Jaime Orgs.). Belo Horizonte: UFMG, 2012.

OUAKNIN, MARC-ALAIN. Mystères de la kabbale. Paris: Assouline, 2010.

PAVIS, Patrice. A encenação contemporânea. Origens, tendências, perspectivas. Nanci Fernandes (Trad.). São Paulo: Perspectiva, 2010.

PESSOA, Fernando. Para ser grande: sê inteiro, nada. In: Obra completa de Ricardo Reis. Lisboa: Tinta da China, 2016.

PIGEAUD, Jackie. Metáfora e Melancolia: ensaios médico-filosóficos. Rio de Janeiro: Ed. PUC Rio e Ed. Contraponto, 2009.

PINHEIRO, P. S. Autoritarismo e transição. Revista USP, São Paulo, n. 9, p. 45-56, mar./mai 1991.

PROUST, Marcel. Du Coté de chez Swann. À la recherche du temps perdu I. Paris: Gallimard, 1988.

QUILICI, Cassiano Sydow. O Ator performer e as poéticas de transformação de si. São Paulo: Ed. Annablume, 2015. 
QUINET, Antônio. A estranheza da psicanálise: A escola de Lacan e seus analistas. Rio de Janeiro: Zahar, 2009.

Revista Civilização Brasileira. Teatro e Realidade Brasileira. (Caderno especial n. 2). Rio de Janeiro: Ed. Civilização Brasileira, set. 1968.

ROOB, A. O Museu Hermético. Alquimia e Misticismo. Colônia (Alemanha): Taschen, 2001.

ROSENFELD, Anatol. O Teatro Épico. São Paulo: Ed. Perspectiva, 2000.

SAMAIN, Etienne. As "Mnemosyne(s)"de Aby Warburg: Entre Antropologia, Imagens e Arte. Revista Poiésis, Tubarão, Santa Catarina, n. 17, p. 29-51, jul. 2011.

SARRAZAC, Jean-Pierre. La Parabole ou l'Enfance du Théâtre. Belford (France): Ed. Circé, 2002.

2004.

. Jeux de rêves et autres détours. Belval (France): Ed. Circé,

. Léxico do drama moderno e contemporâneo. André Telles (Trad.). São Paulo, Cosac Naify, 2011.

SCHOLEM, Gershom. Los nombres secretos de Walter Benjamin. Ricardo Ibarlucía y Miguel García-Baró (Trad.). Madri: Minima Trotta, 2004.

. Walter Benjamin y su angel. Catorce ensayos y artigos. Mexico: Fondo de Cultura Económica, 2003.

SCHWARZ, Roberto. Um livro audacioso. In: KURZ, Robert. O Colapso da Modernização - da derrocada do socialismo de caserna à crise da economia mundial. Rio de Janeiro: Paz e Terra, 1999.

. Martinha versus Lucrécia: ensaios e entrevistas. São Paulo:

Companhia das Letras, 2012.

SEDLMAYER, Sabrina; GINZBURG, Jaime (org.). Walter Benjamin Rastro, aura e história. Belo Horizonte: Ed. UFMG, 2012.

SOUZA, Regina Maria de; GALLO, Silvio. Por que matamos o barbeiro. In: Educação e Sociedade, Campinas, Universidade Estadual de Campinas, ano XXIII, $n^{\circ}$ 79, 2002.

STAROBINSKI, Jean. Les cheminées et les clochers; Vide et création. In: Magazine Littéraire, Paris, nº 280, p. 26-27; 41-42), set. 1990.

. L'Encre de la Mélancolie. France: Édition du Seuil, 2012. 
2014.

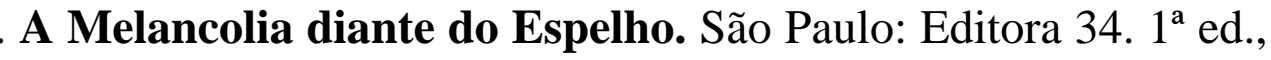

SZONDI, Peter. Teoria do drama moderno [1880-1950]. Luiz Sérgio Repa (Trad.). São Paulo: Cosac Naify, 2001.

. Ensaio sobre o trágico. Rio de Janeiro: Jorge Zahar, 2004.

TROTSKY, Leon. Tres concepciones de la revolución rusa. In: Ernest Mandel (Org.), Trotsky: teoria e prática da revolução permanente. México, D.F., Siglo XXI, 1983.

TUAN, Yi-Fu. Space and Place: the Perspective of Experience. Minneapolis: University of Minnesota Press, 2008.

TURNER, Victor W. From Ritual to theater: the human seriousness of play. New York: Performing Arts Journal, 1982.

1988.

El proceso ritual: estructura y antiestructura. Madrid: Taurus,

- Antropología del Ritual. México, Instituto Nacional de Antropología e Historia; Escuela Nacional de Antropología e Historia, 2002.

TSE-TUNG, Mao. Discurso sobre o trabalho de propaganda (conferência). In Obras escolhidas, vol. 5. São Paulo: Alfa-ômega, 1979.

UN PHILOSOPHE. Revista francesa eletrônica de filosofia, literatura e arte, atualizada semanalmente com discussões, entrevistas e matérias acerca dessas áreas de conhecimento. Disponível em: $<$ https://unphilosophe.com/2017/03/20/melencolia-i-de-durer-et-lamelancolie-chez-les-grecs/>. Acesso em: 25 jul. 2017

WARBURG, Aby. L'atlas mnemosyne. Paris: Ecarquille, 2012. . Atlas Mnemosyne. Madrid: Akal, 2011.

WALLERSTEIN, Immanuel. El moderno sistema mundial I. Madrid: Siglo XXI, 2006.

WILLIAMS, Raymond. Tragédia moderna. São Paulo: Cosac \& Naify, 2002.

WILLIAMS, Raymond. Palavras-chave. São Paulo: Boitempo, 2007.

ZIZEK, Slavoj. Arriscar o impossível. São Paulo: Martins Fontes, 2010. . Bem-vindo ao deserto do Real! São Paulo: Boitempo, 2003. . Em defesa das causas perdidas. São Paulo: Boitempo, 2011. 
O Sujeito Incómodo. O Centro Ausente da Ontologia Política. Lisboa: Relógio D’Água, 2009.

Primeiro como tragédia, depois como farsa. São Paulo: Boitempo, 2009. . Violência. São Paulo: Boitempo, 2014. 


\section{ANEXO \\ VERSÕES DE DRAMATURGIA TEXTUAL. \\ ANATOMIA DA MELANCOLIA - EXPERIÊNCIA I.}

\section{Trechos da primeira proposta dramatúrgica de Ivan Delmanto.}

\section{ESTE É O CAMPO DE REFUGIADOS}

minha vida último estado última versão mal-dita mal-ouvida malrecapturada mal-murmurada na lama breves movimentos nem a milionésima parte tudo perdido quase tudo alguém ouvindo outro anotando ou o mesmo

vida vida a outra em cima da luz diz-se que teria sido minha a intervalos sem volta lá pra cima não é o caso ninguém me pedindo isso nunca lá algumas imagens a intervalos na lama terra céu algumas criaturas na luz algumas ainda de pé

aqueles se arrastando na frente aqueles se arrastando atrás cuja sorte tem sido cuja sorte serão o que sua sorte é cortejo infinito de sacos arrebentados para proveito de todos

outra imagem tão depressa outra vez uma mulher levanta o olha me olha as imagens vêm no começo parte um elas cessarão eu o digo como ouço murmuro-o na lama as imagens parte um como era antes daqui eu as vejo na lama uma luz se acende elas cessarão uma mulher eu a vejo na lama 

cena. Dramaturgia de Ivan Delmanto.

OFF:

Todos os cientistas estavam de acordo

que o peso dos corpos de tantos bilhões

de habitantes em breve faria a Terra

descarrilhar do curso de sua órbita.

A única solução seria exilar

parte da população terrestre no espaço sideral.

Milhões e milhões de seres humanos enfileiraram-se,

de livre e espontânea vontade,

a fim de colaborar com a vida do planeta.

Foram construídos seis planetas pequenos

de concreto armado,

incluindo as leis físicas

que os sustentariam no espaço.

Os planetinhas eram ventilados.

Não havia espaço para bosques e nem campinas.

Mas perfeitos pintores recém-chegados

das melhores academias da Terra pintaram

nas paredes árvores e prados idênticos aos da Terra,

nem uma folha a mais ou a menos.

Estavam tão bem pintados que tentavam os homens

a introduzirem-se neles.

Mas internar-se nessas maravilhas

e dar com a cabeça nas paredes de concreto era a mesma coisa.

Outra medida horrível a que obrigava o pequeno espaço 
era o fim da reprodução:

não podiam reproduzir-se nem os homens nem os animais.

Os animais foram esterelizados.

Os homens e mulheres escolhidos

para participarem do projeto heróico

de salvação da humanidade foram pessoas como eu,

Aceitamos as filas que nos levariam

aos campos de concentração estelares

dos planetinhas.

Deprimidos,podíamos viver

uns ao lados dos outros

sem qualquer espécie de apetite,

até que nossos corpos se extinguissem completamente.

ON:

Eu fui condenada rapidamente

por ser a mais melancólica,

a mais doente entre todos os doentes,

como dizia a última frase de minha sentença:

Eles assim disseram:

jamais se preocupou com a dor alheia.

Jamais deixou de pensar em si mesma.

Seu problema sempre foi maior do que o dos outros.

Permaneci em silêncio.

Decidiram por unanimidade castigar-me

exilando-me no exílio do pequeno planeta de concreto: 
expeliram-me no espaço e, como eram contrários à pena de morte, amarraram minhas mãos ao anel de Saturno.

Sabiam que minha melancolia me garantiria um grande poder de visão para que eu visse o que ocorria à distância, na Terra: deram-me então liberdade para que eu me interessasse quanto quisesse por tudo o que se passasse na Terra mas, em uma medida de caráter pedagógico, para que um dia eu pudesse me reinserir na sociedade dos felizes, no fundo do planetinha de concreto armado, estabeleceram que se eu pensasse, por um momento sequer em mim mesma, afrouxariam-se as minhas mãos e eu despencaria do anel, morrendo no vácuo infinito do espaço.

Quando meus dedos insistiam em não mais me sustentar quando eu repisava pela infinita vez as estrelas mortas de minhas próprias mágoas sem motivação, EGOÍSTA EGOÍSTA

eu deixei de olhar, pela primeira vez, para a Terra.

Olhei à minha volta e viu que nos outros anéis de Saturno 
jaziam pendurados inúmeros corpos femininos, melancólicos e castigados como o meu, todos tentando contemplar a Terra para esquecer de suas próprias dores.

A luz dos fenômenos terrestres demora a nos atingir, penduradas em Saturno.

E quando ferem nossos olhos, provêm de épocas distintas da Terra, de modo que contemplamos em nosso despenhadeiro espacial visões de inúmeros tempos terrestres, em caleidoscópio da história.

Aquele raio trouxe-me a visão dos dois filósofos gregos, Demócrito, pensador do átomo e da perenidade, homem que passava seus dias a rir, e Heráclito, pensador da dialética e do movimento, homem do pranto.

Quantos humores estranhos há no homem Seja na Terra, seja em Saturno, seja no satélite lunar! Se os homens apenas considerassem a mutabilidade deste mundo, E como ele dá voltas,

E à vista de um teatro imenso, tão trágico, tão funesto, tão lamentável, aonde cada sol que nasce é um cometa, cada dia que passa um estrago, cada hora e cada instante mil infortúnios, que homem haverá - se acaso é homem - que não chore?

Se não chora, mostra que não é racional; e se ri, mostra que também são risíveis as feras. 
É preciso ir do extremo do riso ao estremo do choro até que os espasmos explodam nossos órgãos, deixando-nos libertos.

Mas se Demócrito era um homem tão grande entre os homens, e um filósofo tão sábio, e se não só via este mundo, mas tantos mundos, como ria?

É certo, porém, que ele ria neste mundo, e que se ria deste mundo.

Como podia rir-se Demócrito do mesmo mundo e das mesmas coisas que via e chorava Heráclito? A mim, senhores, me parece que ambos choravam, cada um a seu modo O riso, como dizem todos os filósofos, nasce da novidade e da admiração, e cessando a novidade, ou a admiração, cessa também o riso; e como Demócrito se ria dos ordinários desconcertos do mundo, e o que é ordinário, e se vê sempre, não pode causar admiração nem novidade, segue-se que nunca ria rindo sempre, tudo o de que Demócrito se ria, não só lhe desagradava muito, mas queria mostrar que lhe desagradava; Demócrito chorava, como nós as penduradas, mas por outro modo. 
chorar com lágrimas é sinal de dor moderada;

chorar sem lágrimas é sinal de maior dor;

e chorar com riso é sinal de dor suma e excessiva.

É sinal de melancolia.

A dor moderada solta as lágrimas,

a grande as enxuga, as congela e as seca.

Nada digo [senhores] que seja contrário aos princípios

da verdadeira filosofia e da experiência.

A mesma causa, quando é moderada

e quando é excessiva produz efeitos contrários:

a luz moderada faz ver, a excessiva cegar;

Na guerra morrem muitos soldados rindo,

e a razão é, diz Aristóteles

porque são feridos no diafragma:

não ria Demócrito como contente:

ria como ferido; recebia dentro do peito todos os golpes do mundo, e tão mal ferido ria.

O pranto chamava-se assim porque se batiam as mãos

uma com a outra quando se chorava,

porque para chorar não são precisos os olhos,

o pranto dos olhos é mais fino,

o da boca é mais mordaz,

Choram os homens, como racionais e sensitivos,

e ainda as coisas sem razão e sem sentido choram;

Não residem as lágrimas só nos olhos que vêm os objetos, mas nos mesmos objetos que são vistos: 
ali está a fonte, aqui está o rio;

ali nascem as lágrimas, aqui correm;

Nasce o homem já chorando,

e, sem outra culpa mais que haver nascido,

começa a vida e o pranto juntamente,

para que saiba que, se vê a este mundo chorar,

vem para chorar.

se a primeira propriedade do racional é o risível,

o exercício próprio do mesmo racional, e o uso da razão, é o pranto

Já o pranto com riso, como o meu,

É o testemunho de tudo o que, em tristeza de pedra, perdeu.

A vida do espírito oscila

entre o quente e o frio,

entre a ação desenfreada e a contemplação incorpórea.

Aquelas almas, senhores, que tornam-se contemplativas,

são as que baixaram ao corpo como até um rio,

às vezes foram tragadas pela violência da tempestuosa torrente,

às vezes, havendo enfrentado a torrente,

primeiro emergiram e depois regressaram

ao lugar de onde antes haviam caído.

Estas, são pois as almas dos que contemplam,

ocupadas desde o princípio e até o fim em morrer

para a vida nos corpos, a fim de lograr

a vida incorporal incorruptível junto ao espírito da pedra.

Assim ataram-nos à Saturno,

Fusão de contemplação e de mania, de pedra e de boca que devora. 
Demócrito afirmava, em suas lições orais

De filosofia

Que há infinitos mundos, gerados e corruptíveis.

Demócrito dizia que há mundos infinitos

em número no vazio infinito

e que estão compostos por átomos infinitos em número.

Foi em um desses mundos

Que contemplei meu duplo:

Idêntica em sentimentos, corpo e voz

A viver em planeta idêntico à Terra

Também chamado Terra

vida em tudo semelhante à minha

A não ser pelo fato de trabalhar como frentista

Em uma cidade miserável, em guerra civil.

Eu ouvia sua voz chegar, distante mas audível:

Não há mais combustível nas bombas dos tanques.

Somos a última cidade

Cercados por homens armados

Com os rostos cobertos por camisetas

feitos de toxinas

E água estagnada

Sem combustível, [sem trabalho], sem dinheiro, sem homens

Para nos consumir 
E de longe, eu contemplo a história daquela segunda Terra Sem compreender

Rockefeller começou como membro do proletariado e por meio de economia e perspicácia teve sucesso em desenvolver o primeiro monopólio perfeito, a Standard Oil. Não podemos deixar de mencionar essa página notável da história da época, para mostrar como a necessidade de reinvestir o seu excedente acelerou a falência do sistema capitalista global, primeiro entre os terráqueos.

Os Rockefellers entraram para as minas: ferro, carvão, cobre e chumbo; para o transporte urbano, para o transporte marítimo, para o telégrafo, para o ramo imobiliário; para o ramo de seguros de vida, para o ramo bancário.

A derrocada veio quando todo o seu excedente não pode mais ser vendido, consumido ou reinvestido.

$\mathrm{O}$ que fazer com o excedente?

Alguns governantes lançaram-os ao mar, às profundezas perfeitas do mar. Nem assim conseguiram conter a desvalorização, mergulhados que estamos na miséria mais profunda e estelar.

Na natação, eu e meu duplo dividíamos a mesma raia. 
Cada vez que eu mergulhava a cabeça na água, escutava a voz de minha avó morta.

Se haveis viajado, senhores, pelas montanhas, haveis podido encontrar o que eu vi um dia. Entre a aglomeração confusa de rochas amontoadas, em meio de árvores e vegetação, se alçava um pico imenso. Este solitário, obscuro e nu era, sem dúvida, filho de profundíssimas entranhas do globo. Nenhuma vegetação o adornava; nenhuma estação fazia mudar o seu aspecto; as aves apenas pousavam ali, como se ao tocar o instável movimento de uma onda de lava se haveriam de queimar suas asas. Que revoluções subterrâneas, que incalculáveis forças combateram no seio da terra para que este rio de lava, desgarrando as montanhas, comovendo as rochas, transformando líquido em chamas e em blocos de mármore, saísse até a superfície! Que convulsões, que torturas arrancaram do fundo do globo este prodigioso suspiro! Das contradições do mundo emerge nossa melancolia, que nos petrifica.

Desde antes de minha prisão saturnina

Morde-nos a obsessão de que havia

Sob os meus pés, sob a terra onde eu pisava,

Um fígado doente que sangrava

E uma garganta de órfã que gemia.

E via ali

O resultado de bilhões de classes e raças 
Que há muitos anos desapareceram

Nos dias de engarrafamento cósmico, nos dias da morte terrestre, Os prédios daquelas cidades foram incendiados.

As salamandras imensas de fumaça arrancando para a altura, desdobrando contorções monstruosas, mergulhando na sombra cem metros acima.

O fogo crescia ímpetos de entusiasmo, como alegrado dos próprios clarões, Sobre o pátio, sobre o jardim, por toda a circunvizinhança choviam fagulhas, contrastando a mansidão da queda com os tempestuosos arrojos do incêndio.

OFF:

Por toda a parte caíam escórias incineradas, que a atmosfera flagrante repelia para longe como folhas secas de imensa árvore sacudida. Quando as bombas e explosivos caseiros apareceram, desde muito tinham começado os desabamentos.

De instante a instante um estrondo prolongado de descarga, às vezes surdo, agitando o solo como explosões subterrâneas. Às vezes, a um novo alento das chamas, a coluna ardente desenvolvia-se muito, e avistavam-se as árvores terrificadas, 
imóveis;

Do interior dos prédios de vidro, como das entranhas de um animal que morre, exalava-se um rugido surdo e vasto. Pelas janelas, sem batentes, sem bandeira, sem vidraça, estaladas, carbonizadas, via- se arder o teto; desmembrava-se o telhado, furando-se bocas hiantes para a noite.

No dia seguinte ao da nossa morte, sem que a chuva contínua os vencesse, nasciam filetes de fumaça, mantendo um nevoeiro terroso e um cheiro forte de cadáveres queimados. As paredes mestras sustentavam-se firmes, varadas de buracos como janelas, como arrombamentos, negrejantes como da ação contínua de muitas idades de ruína.

$\mathrm{Na}$ atmosfera luminosa da manhã flutuava o sossego fúnebre que vem no dia seguinte sobre o teatro de um grande desastre. Nós somos essas ruínas. Um cosmos de ruínas.

Todos os planetas ao fim de certo tempo, reduzidos por si mesmos a pedaços, devem precipitar-se, uns sobre o Sol, outros em suas estrelas.

Mas podemos ver que ainda o Sol gira em torno do próprio eixo e, portanto, deve crer-se o mesmo das estrelas; 
um e outras, com o passar do tempo, devem, não menos que os planetas, dissolver-se, e suas chamas dispersarem-se no espaço.

Desaparecidos os planetas, as Terras, o Sol e as estrelas, mas não sua matéria, formar-se-ão desta novas criaturas, diferenciadas

em novos gêneros e novas espécies e nascerão, pelas forças eternas da matéria, novas ordens de coisas e um novo mundo. Mas sobre as qualidades deste e daquelas, bem como das incontáveis que já existiram e das infinitas que virão depois, não podemos conjeturar nem minimamente.

Vou abrir meus dedos que seguram-me, exaustos, Prendendo-me ao anel de Saturno, E voar pelo espaço vazio.

[Fim] 